

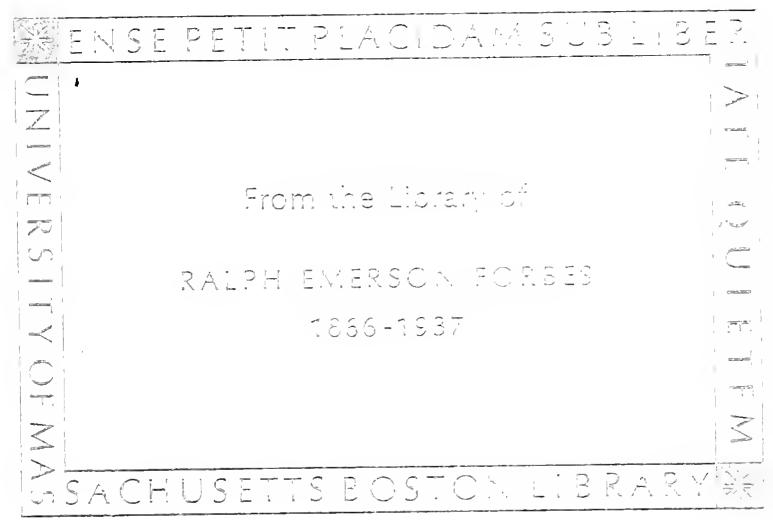






\section{THE AMERICAN ARMY IN THE EUROPEAN CONFLICT \\ TRANSLATED FROM THE FRENCH BY THE AUTHORS}




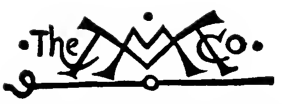

THE MACMILLAN COMPANY

NEW YORK - BOSTON - CHICAGO - DALLAS

ATLANTA - SAN FRANCISCO

MACMILLAN \& CO., LIMITED

LONDON - BOMBAY - CALCUTTA

MELBOURNE

THE MACMILLAN CO. OF CANADA, LTD.

TORONTO 



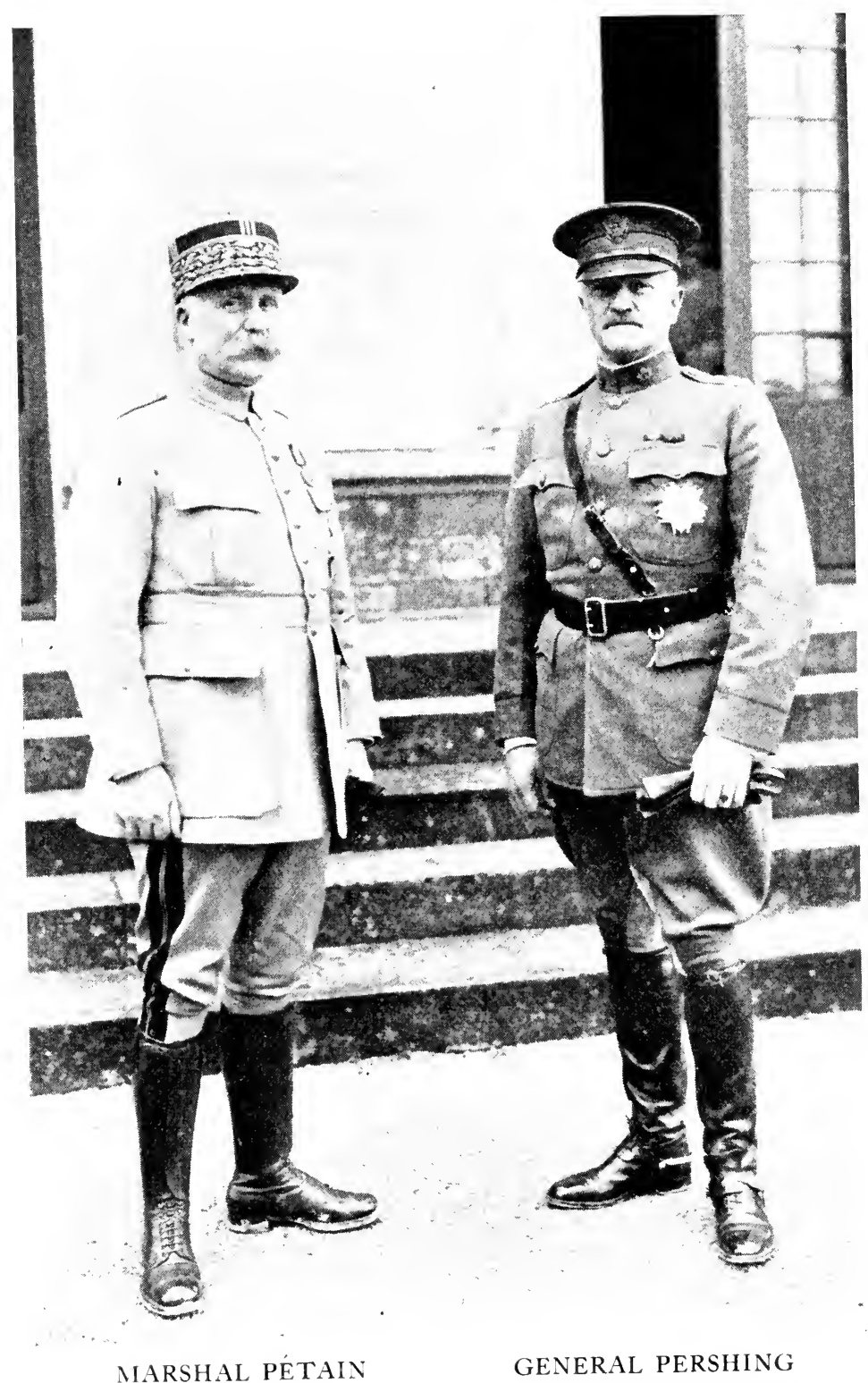

Commander in chief of the Commander in chief of the French Armies American Expeditionary Forces AT CHAUMONT 


\title{
THE AMERICAN ARMY IN THE
}

\section{EUROPEAN CONFLICT}

\author{
BY \\ COLONEL DE CHAMBRUN \\ AND \\ CAPTAIN DE MARENCHES
}

WITH MAPS

Jew 鼠ork

THE MACMILLAN COMPANY

1919

All rights reserved 


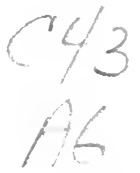

COPYRIGIIT, 1919

BY THE MACMILLAN COMPANY

Set up and electrotyped. Published November, I919. 


\section{CONTENTS}

\section{CHAPTER I}

PAGE

The Declaration of War - Universal Military Serv$\mathrm{ICE} \cdot \bullet \cdot \bullet \cdot \bullet \cdot \bullet \cdot \bullet \cdot \bullet \cdot \bullet$

\section{CHAPTER II}

Arrival of General Pershing in France-First Plans - Formation of the General Staff - Organization of Fighting Units - Selection of Ordnance Material and Other EquipmentMethods OF Training - Camps - Schools - Establishment of General Headquarters at ChauMONT

\section{CHAPTER III}

Establishment of the Lines of Communication Organization of the Services of. the Rear $\cdot \quad 78$

\section{CHAPTER IV}

First Appearance of American Contingents on the French Front - The First, Second, TwentySixth, ANd Forty-Second Divisions . . . . . II6

\section{CHAPTER V}

Participation of American Forces in the Spring DeFensive AND in the Sùmmer Counter-Offensive OF 1918

\section{CHAPTER VI}

Organization of the Main Services of the ExpediTIONARY FORCES - ChIEF OF ARTILLERY - TANK Corps - Chief Engineer - Air Service - Signal 


\section{Contents}

Corps - Medical Department - Quartermaster - Ordnance - Chemical Warfare - Inspector General - Judge-Advocate . . . . . . . . . . 186

\section{CHAPTER VII}

Situation of the Expeditionary Forces at the BeginNing of SePtember, 1918 .

\section{CHAPTER VIII}

The American Army During the General Offensive, September-November, i9i 8 (Battle of St. Mihiel) - Operations Between Meuse and Argonne . 262

\section{CHAPTER IX}

The March to the Rhine .

\section{CHAPTER $\mathrm{X}$}

Part Taken by American Units in the Operations on British Front - And in Secondary Theaters of THE WAR . . . . . . . . . . . . 320

\section{CHAPTER XI}

Development of the Lines of Communication - ORganization in AMerica - Sea Transportation Growth of the Services of the Rear in France Director General of Transportation - Motor Transport Service - Military Board of Allied SUPPLY

\section{CHAPTER XII}

Great Benevolent Associations Under the Military Authority - American Red Cross - Young Men's Christian Association - Knights of Columbus - Salvation Army - American Library Association - Jewish Welfare -- Young Women's Christian Association, etc., etc. . . . . 36i 


\section{Contents}

\section{CHAPTER XIII}

PAGE

Franco-American Coöperation - Conclusion . . 385

Appendix I - Order of Battle of the American Expeditionary Forces at the Date of December I, I9I8 $39 \mathrm{I}$

Appendix II - Organizations of the American Expeditionary Forces Cited in General Orders by the French High Command . . . . . . . 410

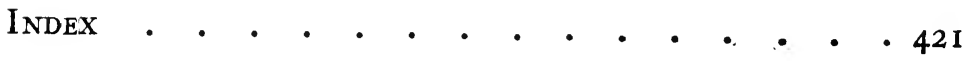





\section{LIST OF ILLUSTRATIONS}

Marshal Petain and General Pershing at Chaumont . Frontispiece

Situation of American Units before the summer counteroffensive . . . . . . . . . Facing page 162

Location of American Divisions on the Ist of September, 1918 . . . . . . . . . . . . . 248

Plan for Attack of the Saint-Mihiel Salient . . . . 266

Operations between Meuse and Argonne . . . . . 288

Organization of the Services of the War . . . . 340 



\section{THE AMERICAN ARMY IN THE EUROPEAN CONFLICT}

\section{CHAPTER I}

THE DECLARATION OF WAR - UNIVERSAL MILITARY SERVICE

Although the American people have ever been patient and slow to anger they are not incapable of warlike resolution, and since 1776 have more than once given proof of their fighting spirit. But before taking up arms the nation must be permeated with a sense of the responsibilities involved, and possess a clear notion of the inherent justice of her cause.

Placed by nature in a position of independence and political isolation, untroubled by international disputes, the United States has watched foreign conflict from afar. War has seemed an eventuality too fearful to be lightly invoked, and many grave persons considered that nothing short of a territorial invasion would ever arouse the Great Republic to an ordeal by battle.

Such has never been our personal opinion.

If the country, as a whole, seems peaceful and patient, the citizen is often a militant idealist, prompt to redress a wrong, proud of his independence, and ready to fight at a moment's notice on a question of personal or national honor. 
The difference between his individual characteristics and those of the mass may perhaps be explained by the country's vast dimensions and the particularism of each state or city, which tends to concentrate popular attention upon affairs of local importance and to limit the range of political interest and activity to each special district or community.

It is thus natural that the first appeal to a broader national sentiment should penetrate slowly through these vast areas, that a long interval must follow the first alarm and precede executive decision.

This phenomenon has been noticed on previous occasions of political unrest. ${ }^{1}$ American wars have been remarkable for breaking out with sudden violence after a protracted period of hesitation, contradiction, party polemics, and sometimes even apparent public indifference. Thus the country passed through many gradations of feeling during the months which preceded the conflict with Spain; long also were the years of tension that preceded the Civil War; McKinley, like Lincoln, was for a long time considered as a "temporizer." 2

1 It took all the veneration and military prestige of Washington to enable him to run counter to the strong trend of public opinion which, in America, favored the great French Revolution; when the violence of the American sentiment was such that nothing short of the President's inflexible character and the immense popularity which he enjoyed could have availed to prevent a declaration of war against England. (See Tocqueville and Marshall.)

2 A long period of political tension and press provocation preceded the war with Spain. President McKinley, a warm advocate of arbitration, had declared that he would never allow outside pressure to force him into war, but the sinking of an American battleship in Havana Harbor aroused the belligerent spirit to such an extent that the President was compelled to follow the pronouncement of the Investigating Commission. The specialist verdict that the Maine had been blown up from without at once precipitated the country into war. 
Germany's great diplomatic error was her failure to judge the country's moral evolution during the period of neutrality.

The Imperial Government was incapable of understanding that a people which had not sprung to arms at the first provocation might yet be goaded beyond endurance by the second or third repetition of a grave offense.

It was only when the nation was ablaze with anger that the military psychologist beyond the Rhine realized that the fires of wrath had been a long time smoldering. And yet a brief survey of Foreign Office reports concerning past wars clearly indicates that this is not the first occasion on which European statesmen and diplomatists have been misled into thinking that American patience was national apathy.

Few in the Old World foresaw the formidable struggle between South and North. Contemporary argument tended to show that neither of the opposing factions would actually come to a trial of force, that President Lincoln, with his peace-loving nature, his horror of fratricidal strife, with what was then supposed to be his "hesitating" character, could never give the signal for battle.

It was repeatedly declared that a commercial and agricultural people would not and could not make the sacrifices which such a war must entail. That logically then as now - war could not be.

Such was the onlookers' conclusion in $186 \mathrm{I}$ when the first gun fired upon Fort Sumter was echoed by Lincoln's thrilling proclamation. Such was the conclusion of Germany in 1916.

A country which had submitted to a violation of her inherent rights at sea was one which would never fight. 


\section{The American Army in the European Conflict}

Germany proclaimed that although some occasional American Don Quixote, led perhaps as much by a taste for adventure as by chivalrous impulse, might enlist under the British flag or enroll in our Foreign Legion, such isolated cases counted for nothing in the mass of American commercialism, and that the people, as a whole, were far too busied in the pursuit of material welfare to be aroused in a cause pertaining merely to abstract right and wrong. That, in short, America would have "Peace at any Price."

And yet America had endured in her Civil War a bitter four years' struggle which has since been aptly characterized as "right fighting with right." How could those who witnessed the titanic combat of brother against brother suppose that this same country would hesitate in a clearly defined cause of Right and Wrong? of Humanity against Barbarism? How could the Great Republic, founded on the doctrine of Thomas Paine, bred in the cult of liberty and social justice, stand passively aside and watch the ideals her fathers bled for trampled beneath the iron heel?

As we in France watched from the trenches at Verdun the flaming of the war beacon in the western sky, as we followed the impassioned utterances of those representative statesmen who in House, Senate, Press and on the public platform, called on their fellows to remember the country's honor and arise in the cause of freedom no doubt ever entered our minds as to the eventual outcome of America's moral crisis.

We knew that though many of us would not live to see the triumph of her ideals, yet her ideals would one day triumph; that if America hesitated longer than some who loved her might have wished, before taking the final 
decision, it was rather the hesitation of one who asks how and when and not whether to act.

A complete study of the causes which led up to the eventual rupture between the United States and Germany is not within the scope of this work, nor could French soldiers with propriety discuss the divergent opinions and different political tenets of American public men.

Neither can we, for the same reasons, examine into the far-reaching influence of overt and concealed German propaganda, acting as an effective brake on the native impulse of the country to "take sides" in the European conflict.

The stirring events which preceded America's entry into the war are still fresh in every mind. They are, perhaps, as yet too near for any author to view them with the necessary mental perspective, or to embody their history in permanent literary form.

It must be our rule - except in describing certain material organizations where official statistics are given to speak only of those things which have come under our personal observation and which occurred upon our own theater of war.

Those who desire a more complete picture than we can give of certain personalities who played an active part in the drama of America's development as a world power, and who wish to study the two schools of thought which struggled with equal ardor to impose their respective convictions upon the mass of their fellow-citizens, will find a quantity of such records among the files of contemporary journalism during the war, among American state papers and official publications.

The President's published addresses, proclamations, and epistles, together with the correspondence between 
the Secretary of War and Colonel Theodore Roosevelt, will give the searcher for historical data a comprehensive view of both sides of the question of military preparedness.

As for us we must limit ourselves rigidly to a brief recital of the facts - for in these pages facts alone import.

Their dates mark the steady progress of the moral preparation of the citizen-soldier whom the nation was soon to send into battle on a foreign soil.

Toward the end of April, I9 I 5, certain Americans contemplating passage on the British liner Lusitania received warning from the German embassy in Washington that they would do better to abandon their project of sailing on this vessel, it being the intention of the German Admiralty to sink her during the voyage.

The threat was generally considered absurd; such a crime was thought to be too flagrant a breach of neutral rights for Germany to attempt.

Nevertheless the fact that foreign officials should dare to make this threat and had even utilized the American press to sound the warning, aroused great wrath among certain Americans. Quite a general demand was made that the German Ambassador who had thus overstepped diplomatic prerogatives should at once be given his passports.

On the seventh of May, the great liner was attacked by two German submarines - one of which was identified as the $U_{2 I}$ - and sunk without warning near the head of Old Kinsale off the Irish coast, no effort being made to save either passengers or crew, of whom upwards of eleven hundred, including more than a hundred Americans, perished. 
From this moment we may date the rise and growth of an active belligerent spirit among the American people.

During the horrified pause which followed this latest German atrocity a declaration was made and sworn to that the ship carried munitions of war and that Germany's action was justifiable on that ground, although it was subsequently proved and confessed that the witness who alleged having seen guns on the Lusitania was paid to say so by funds collected for that purpose by the German propaganda. The check on popular indignation which the debates on this question involved had been effective. When, on May i 5 th, the President of the United States sent a formal warning to Germany that no further outrage of the sort would be tolerated or go unpunished, this threat elicited a very humble response from the Imperial Government, offering indemnities for loss of American life and expressing sincere regret for the incident.

The occasion to declare war on account of the Lusitania had by this time passed. Nevertheless American opinion had been much incensed. In many public centers "Remember the Lusitania" was placarded. Memorial meetings were called. Money for the allied cause and for the widows and orphans of the war as well as for the victims of the submarines, poured into Europe from the United States. The youth of America began to group itself together and form societies of military preparation. ${ }^{3}$ In some schools, practical efforts were made toward obtaining a certain amount of soldierly discipline.

Nine months elapsed without any definite incident tending toward a rupture of friendly relations, for, although

${ }^{3}$ General Leonard Wood's untiring crusade on platform and in the press for military preparedness elicited a warm response from the military elements of the country. 
submarine attacks continued against vessels carrying Americans on board the cases generally admitted of discussion on technical grounds and terminated either with apologies and indemnities, or the proof that the aggressors, as in the case of the Ancona, belonged to the Austrian, and not the German, Navy.

American indignation, however, had been excited. The exchange of diplomatic notes between the United States and Germany became, on the part of the former, progressively menacing until the climax was reached.'

On August 19, I915, the English steamer Arabic was sunk off the Irish coast. Two Americans were numbered among the forty-four victims. On November 9 th the Italian ship Ancona met a similar fate in the Mediterranean. On January 2, I9I6, the Persia also was sunk without warning.

Finally on March 24th the Channel packet Sussex, carrying American passengers and mails, was sunk in the narrow seas by a German submarine.

This new outrage elicited a message to Germany far more aggressive in tone than the former notes relating to like incidents and terminated with a clearly defined warning that should such another crime be perpetrated, the American Government would feel obliged to sever on the instant, all diplomatic relations with the German Empire.

The Imperial Government reflected seriously upon this message and at length gave solemn assurances to the President of the United States that no more ships would be sunk without previous warning and without legitimate steps being taken to safeguard the lives of passengers. It should, however, be noted that Germany did not hesi- 
tate to demand America's intervention with a view to lessening the rigors of the British blockade.

This mild answer and the careful observance of her word during the rest of the year were probably induced by a very serious shortage in Germany's sea flotilla which required several months to reconstitute. Whatever her motive, the result was satisfactory to America, who appeared to have obtained a great moral victory in forcing the Imperial Government to "back down," and it was generally declared that by his vindication of neutral rights and humanitarian principles, President Wilson's diplomacy had triumphed.

From the German point of view, also, the policy was not unsuccessful. During eight months, America, reassured by the peaceful and friendly declarations of Germany, took no step in military preparation. Much of that spiritual "readiness for war" which had begun to be felt in the country at large had even been checked and more or less undone by the idea that Germany was pledged henceforward and forever to respect American rights at sea and definitely abandon her terrorization of all neutral nations by her submarine menace.

In reality it was far from that country's intention to revoke a policy so essential to the prestige of her sea command.

No sooner had a more numerous and powerful submarine fleet been constructed, than the German Ambassador in Washington handed to the Secretary of State a note dated January 3 Ist, I9 I 7, revoking all former promises. This note now declared it to be the inherent right as well as the irrevocable intention of the Admiralty to sink without warning, any vessel, whether neutral or belligerent, in a zone defined by her as forbidden. 


\section{Io The American Army in the European Conflict}

The indignation in America was now at fever heat. The national press, while loudly censuring Germany's duplicity, called upon the President of the United States to make a definite and hostile declaration. Mr. Wilson's patience was indeed at an end. Although on February $3 \mathrm{~d}$ he once more expressed incredulity concerning Germany's actual intention to carry out her monstrous threat, he nevertheless felt it incumbent upon him to fulfill his own menace to that power by taking the course indicated by him in the previous year and recalling his ambassador from Berlin.

The presidential message concluded with the following words :

"... We shall not believe they are hostile to us until we are obliged to believe it: and we purpose nothing more than a reasonable defense of the undoubted rights of our people."

The world was not long to remain in doubt regarding the definition of Germany's hostile attitude by an overt act.

Within a few days two American vessels were sunk the Housatonic and the Lyman M. Law - and, on February 26, I917, the President appeared before Congress to ask a special grant of power authorizing him to arm American ships against similar aggressions. ${ }^{4}$ At the same time he confessed himself

"For a time unable to believe that such things would be done by any government that had hitherto subscribed to the humane practices of civilized nations."

4 The Cunarder Laconia with two Americans aboard was sunk at the same time. On the eighteenth of March the American ships, City of Memphis, Illinois, and Vigilancia, met the same fate. On March 2 st the Healdton, crossing from Philadelphia to Rotterdam, was sunk without warning and with twenty-one victims. On April rst the Aztec was sent to the bottom. 
The die had now been cast and wave upon wave of popular enthusiasm arose as one epoch-making event succeeded another.

On April 2, the President branded:

"The present warfare of Germany against commerce a warfare against mankind."

And this statement was followed in four days by the solemn declaration of a state of war between the United States and Germany. Orders were also given for the removal of alien enemies from the civil territory of the Union and their forcible detention in concentration camps.

The presidential address was.a strong denunciation of the actions in the United States of the German governmental agents during the three years of America's neutrality.

"It has filled our unsuspecting communities and even our offices of government with spies and set criminal intrigues everywhere afoot against the National Unity of Council, our peace within and without, our industries and our commerce. Indeed it is now evident that its spies were here even before the war began and it is a matter of fact that the intrigues which have more than once come perilously near to disturbing the peace and dislocating the industries of the country have been carried on at the instigation, with the support and even the personal direction, of official agents of the Imperial Government accredited to the United States."

After a further arraignment of such procedures, the President continued with a very noble and eloquent statement of American aims, now that her final participation in the European struggle was definitely decided.

"We have no selfish ends to serve, we desire no conquest, no dominion; we seek no indemnities for ourselves, no material compensation for the sacrifice we shall freely make. We are but one of the champions of the rights of mankind." 


\section{2 \\ The American Army in the European Conflict}

Although the public mind was ripe, the country was materially quite unready for combat. With characteristic boldness America had in fact declared war without the slightest military preparation at a moment when the withdrawal of Russia from our alliance had placed the allied cause in a precarious situation.

No one as yet knew what form American participation might be called on to take. Was an army to be raised? Was a fleet to be sent abroad or to guard the coast at home against a submarine aggression or bombardment from the sea? Was a rising of the dissatisfied proGermans to be feared from within?

In order to discuss some of those questions it was decided on the part of both France and England to send missions to the United States.

On the tenth of March accordingly, the French Prime Minister, M. Ribot, organized a war mission. ${ }^{5}$

No one better than Marshal Joffre could have been selected for such an embassage, nor could a more powerful appeal have been made to the public imagination.

His personality was already familiar in the United States, where his simplicity, strength, and practical common sense would lend weight to any proposition he might suggest.

The wave of enthusiasm which greeted the arrival of the French war mission gave new energy to the conscription movement.

It is scarcely too much to say that the eventual triumph of the Allies was assured on the day when House and

5 This mission was headed by M. Viviani, Minister of Justice and Vice-President of the Cabinet Council. The members were: Marshal Joffre, Vice-Admiral Chocheprat, and Marquis de Chambrun, deputy, who left Paris on April 15, 1917. 
Senate voted the measure for universal and compulsory military service in the United States.

When, after a tour of the great cities of the Union and the French-speaking provinces of Canada, the French and British missions joined forces in New York and marched through the city, acclaimed by perhaps the largest throng of human beings ever assembled for such an occasion, it was evident to all that the tide of war was about to turn; that America was entering the European conflict determined to achieve success and ready to fight for it as of old "to the last dollar and to the last man." On that day no one in America doubted the eventual triumph of the allied cause.

Political tension was at an end; the war spirit coursed through every vein and artery of the vast continent. It only remained to organize this great moral force, to give practical instruction to the youth of America eager to learn how best to develop their martial spirit into military efficiency.

On the day that war was declared, April 6, 1917, the permanent army of the United States counted 190,000 men distributed in small detachments - regiments, battalions, and even companies - over the immense territory of the Union and her colonial dependencies. An expeditionary corps recently equipped for service in Mexico had just been disbanded upon the completion of their mission.

The regular army had recrossed the Rio Grande, leaving upon the border a large force of cavalry and some elements of infantry, which latter would have scarcely amounted to a brigade. The National Guard units, which had also been employed upon the border, had been 


\section{I4 The American Army in the European Conflict}

relieved and sent to their respective States, only a small number of Pennsylvania militia still lingered near the Mexican frontier. Thus war surprised the American army, reëstablished upon a peace footing and entirely unprepared by any previous attempt at mobilization, for taking part in a foreign war. ${ }^{6}$

Although the country had been recently divided into military departments this reorganization was purely territorial in character, corresponding approximately to the regional distribution in France before the war of I 870 .

The formation of divisions, which was contemplated in some of the new military departments, remained only in prospect, and it may be stated that the only appreciable advantage which had accrued to the army during the period of political tension was that the ranks of existing organizations were increased by numerous voluntary enlistments. ${ }^{7}$

This army before November I, I9I 8 , was to swell to the formidable array of I 81,095 officers and 3,483,444 men, of whom more than two millions crossed the Atlantic.

To carry out this gigantic mobilization, to secure the number, form the commanding officers, and organize the fighting units, an immense effort was necessary.

6 It should not be forgotten that Colonel Roosevelt, since two years, had never ceased to advocate military preparedness. Through personal prestige he was able to enroll a sufficient number of volunteers to make up a division which was complete on paper.

7 The enlistments for the fiscal year 1917 totalled 160,084. It must be also considered that the Mexican expedition resulted in perfecting the training of the regular troops which participated. The National Guards who remained on the border also took advantage of this situation to improve their military training. 
Under the modest title, "An act authorizing the President temporarily to increase the military establishments of the United States" was voted. This epoch-making law, on May i 8 th, created compulsory military service by selection ${ }^{8}$ and thus secured the number necessary to create an army.

${ }^{8}$ In 1814 , in spite of the political influence of President Madison and the no less great prestige of Secretary of War Monroe, a bill was introduced with a view of obtaining for the Executive the power to raise, by means of draft, a national army. Opposition developed and peace came before this bill was enacted. But in $186_{3}$, when the war of secession was at its height, America had recourse to conscription. From the decision of the Supreme Court upholding the draft law of r917, we extract the following quotation which serves to show that the Federal Congress in passing the act, "Authorizing the President to increase temporarily the military establishment of the United States" remained completely within the constitutional tradition:

"In that year, when the mutterings of the dread conflict which was to come began to be heard and the proclamation of the President calling a force into existence was issued, it was addressed to the body organized out of the militia and trained by the States in accordance with previous acts of Congress. (Proclamation of April r 5, 186r.) That force being inadequate to meet the situation, an act was passed authorizing the acceptance of 500,000 volunteers by the President to be by him organized into a national army (Act of July 22, 186r). This was soon followed by another act increasing the force of the militia to be organized by the States for the purpose of being drawn upon when trained under the direction of Congress (Act of July 29, r86r). The two acts when considered together present in the clearest possible form the distinction between the power of Congress to raise armies and its authority under the militia clause. But it soon became manifest that more men were required. As a result, the act of March 3, 1863, was adopted, entitled, 'An act for enrolling and calling out the national forces and for other purposes.' By that act, which was clearly intended to directly exert upon all the citizens of the United States the national power which it had been proposed in 1814 on the recommendation of the then Secretary of War, Mr. Monroe, every male citizen of the United States between the ages of twenty and fortyfive was made subject by the direct action of Congress to be called by compulsory draft to the service in a national army at such time and in such numbers as the President in his discretion might find necessary. In that act, as in the one of 1814 , and in this one, the means by which the act was to be enforced were directly Federal and the force to be raised as a 


\section{I6 The American Army in the European Conflict}

Never before had so great a country and in so brief a time realized such a basic transformation of its fundamental principles and most inveterate customs, and this with the unanimous consent and enthusiastic approval of all parties concerned.

The drafting of this measure not only determined the general sources from which the new contingents were to be drawn, but also arranged the principle of their distribution. The simple mechanism of this law gave, when put into application, an even greater result than that which had been foreseen. ${ }^{9}$

From the fifth of June, 1917, to the twenty-fourth of August, I9I8, I0,48 I,000 citizens between twenty-one and thirty years of age inscribed themselves at the registration boards.

This age limit was the one first determined upon; but later on, with a view to avoid weakening any one category of worker and thereby defeating the economic interests of the country which it was so important to uphold, the age limit was extended to embrace those from eighteen to forty-five. In consequence of this extension, the number of inscriptions rose to $23,709,000$. It thus became evident that "The act authorizing the President to

result of the draft was therefore typically national, as distinct from the call into active service of the militia as such. And under the power thus exerted, four separate calls for draft were made by the President and enforced. That of July, 1863, of February and March, 1864, of July and December, 1864, producing a force of about a quarter of a million of men."

9 "The whole nation," said the President on the eighteenth of May, 1917, "must be a team in which each man shall play the part for which he is best fitted. To this end Congress has provided that the nation shall be organized for war by selection. Each man shall be classified for service in the place to which it shall best serve the general good to call him. ... It is in no sense a conscription of the unwilling, it is rather a selection from a nation which has volunteered in mass." 
temporarily increase the military establishment of the country" was capable of furnishing the numbers which would swing the balance of power to the Allies if it might be possible to organize, equip, and transport to Europe such large masses of men. Method was the first thing required in order to select among the men who had registered those best fitted for active service.

The Federal Government and Congress had emphasized their intention to apply the new laws in a democratic spirit of equity. It was, however, essential to avoid mustering those individuals indispensable to the support of their families, those who were necessary to the material prosperity of the country, such as miners, agricultural and industrial workers, those employed in the great public services, and also the proselytes of certain religious sects which forbid their adherents to carry arms.

On the twenty-second of May the services were organized for recruiting operations at the War Department, and General Crowder, late Judge-Advocate, was placed at the head of the new services with the title of Provost Marshal General.

Each State had been divided into districts of registration comprising about 30,000 inhabitants. A registration board consisting of three members, usually a local magistrate, a physician, and a clerk was to be found in each district.

It was accordingly before these boards, assembled over the entire territory of the United States and on a date set by the President, that the men belonging to the categories which came under the new law were to present themselves. In less than sixteen days ${ }^{10}$ the central services at Washington were in possession of all the results of the first ${ }^{10}$ The first conscript was drafted into the national army on July 3 oth. 
military census which comprehended almost ten million names. ${ }^{11}$

The average registration was about 2,500 in each district. The number of registrants, recapitulated in each State, permitted the Federal authorities to determine the proportion which was to be furnished by each one when the time came to raise the effectives. In the completion of their work, which they handled in the same way as the voting machinery, these registration boards were succeeded by , local incorporation boards, ${ }^{12}$ charged with the duty of examining and classifying registrants in order to select among the names inscribed the men who were to be incorporated. These formed Class $I$ and were first rendered liable for military service, those in the other classes being granted temporary exemptions. Like the registration board, these local boards were formed of three members appointed by the State governor and approved by the President. They ordinarily comprised a prominent citizen of the locality, a sworn-in physician, and a clerk. ${ }^{13}$ Practically all cases of exemption were examined by these boards, except those reserved for the district boards, where more delicate cases, such as exemptions, asked for on account of industrial or agricultural reasons were passed upon. ${ }^{14}$

In what order might the citizens who had registered expect to be inducted into service?

It was decided that the system of drawing by lot should

11 The disparity between this figure and that of $10,481,000$ given above is explained by the number of men who had attained military age between the first census operations and that of August 24, 19r8.

12 The local board numbered 4,552; the district boards numbered 156 .

13 Under certain circumstances the registration board was transformed into a local board.

14 There existed one or more district boards in each Federal district. 
be applied and one of the Senate halls was set apart for this procedure.

Thanks to this very simple method recruiting operations were decentralized and placed in the hands of the regional authorities in each State, the Federal Government only intervening in the process of drawing by lot.

Certain modifications were made in the detailed application of the draft law. After December I 5, I9I7, the administration of the law was improved by the system of classification that was employed in the selection of men. The economic needs of the nation required that men whose removal would interfere with its civic, family, industrial, and agricultural life should be taken in the order in which they could best be spared. On December I 5 th all exemptions that had previously been granted were annulled and all registrants were required to file "questionnaires" giving detailed information in regard to industrial status. On May I6, I9 18, according to a joint resolution of Congress, it became possible to frame new regulations whereby the quotas to be furnished by the several States were apportioned according to the number of registrants in Class I instead of according to the population as was required by the original act.

Additional types of local boards were established later. Medical advisory boards were appointed at a later date by the President on the recommendation of the State governors. At the same time legal advisory boards were also established to assist registrants and draft officials in the interpretation of the Selective Service law. The number of the members of these committees, particularly the medical personnel, was augmented. The Executive defined with greater exactitude what the motive for such exemptions were to be, but it may here be said in 
a general way that no fundamental changes were made in the application of the conscription laws.

In spite of the fact that many members of Congress had, during the discussion of this military legislation, objected that it would be difficult if not impossible to apply the measure with equity, their fears were not justified.

The Secretary of War, to whom is due in great measure the success of this legislation, attributes the merit of it to the zealous manner in which the State governors performed their task and especially to the immense popular enthusiasm, which carried all before it.

"If the army," said he in November, I9 18, " had been obliged to create a new set of salaried Federal officials to handle the draft, we would not have a force of over two million men on European soil to-day. The draft secured a large army in record time without unjust discrimination or destruction of industry; and it gained the respect and support of the American people."

The mechanism of the recruiting system may thus be summed up in a few words: The central power merely fixed the total figure to be obtained and decided upon the number to be contributed by each State. The governor of each State was, in his turn, to distribute the effectives which had been called for among the different local boards, and these finally were to designate the men whom they had found apt for service.

As we have said, the law besides laid down certain principles of general organization.

While respecting the existing text of the National Defense Act promulgated in 1916 the legislators decided first to increase the Regular Army to a strength of I 8,033 officers and 470, I 85 men; second, to increase the National 
Guard to 13,377 officers and 456,800 men; finally, to create a new army called "National Army" to be entirely composed of men supplied by conscription.

The military forces of America were thus to include three different organizations: the Regular Army, the National Guard, and the National Army. The first composed of professional soldiers to whom should be added voluntary enlistments and, if necessary, men supplied by the draft; the second, comprehending National Guard volunteers and eventually drafted men; the third, which was an entirely new organization, was to be formed from the contingents supplied by the compulsory draft .

But as time went on, a succession of measures tended to break down the barriers separating these three armies from one another. It was decided that in the Regular Army, as well as in the National Guard, voluntary enlistments would be accepted only for the duration of the war. The age limit of men who signed these enlistments was unified in both armies. The pay, indemnities, and promotions were made practically identical for the entire forces of the United States. Thus the law had created three nuclei or centers of organizations and training rather than three different armies.

The volunteer, whose desire was to fight as soon as possible - and there were many such in America at this time - enlisted in one army rather than in another with but one object in view, that of taking the shortest way to the battle-fields in France.

As the war spirit grew, this state of mind became pronounced in all classes; among regulars and volunteers as well as army conscripts.

Although at the beginning the War Department endeavored to maintain in the National Guard and in the 


\section{The American Army in the European Conflict}

National Army the links which are generally established between men coming from the same town or village, and to preserve the traditions of certain military organizations it was to be foreseen that a tendency toward amalgamation and the formation of one national army would become more and more evident as time went on.

Moreover, the constantly growing necessity to call upon the resources of the country at large in order to keep up, at full strength, the organizations fighting at the front or training at the rear tended to bring about the same phenomenon as had been already observed in France: a growing inclination to dissolve all differences existing between active and reserve formations.

From the month of August, I9 I 8, the existing barriers between the American units were abolished. One army only remained: The Army of the United States.

In order to complete the Regular Army and the National Guard - to the extent permitted by law, and to form the first contingent of the National Army, ${ }^{15}$ President Wilson called upon 687,000 men to be inducted from the first conscription. Later on the total of inductions reached 2,800,000 men. ${ }^{16}$

15 The President was authorized in the first place to constitute the National Army by two successive calls for 500,000 men. The first contingent, however, consisted of 637,000 , in order that the regular army might be brought up to the number authorized by the National Defense Act and afterward to dispose of the 500,000 necessary for the formation of the National Army.

16 Slightly over $2,800,000$ of the registrants were inducted into military service, 2,54r,000 through calls issued to local boards to furnish their allotted quotas, and 259,000 through inductions of individuals. Approximately 140,000 of the latter were inducted in October and during the first ten days in November for the Students' Army Training Corps. With the exception of these students and a few thousand volunteers, no men of the last registration were inducted into the army.

$\mathbf{x}, 680$ officers were commissioned during the last eleven months preced- 
It was an easier task to raise these forces than to officer them. On June 3oth there were in all the Regular Army but 6,1 59 officers, and among these only 4,500 had seen more than one year's service.

The National Defense Act, of which we have previously spoken, had foreseen the formation of an Officers Reserve Corps, but on the declaration of war this law had been in effect for somewhat less than a year and the 7,957 citizens who were inscribed upon the registers as reserve officers had had but a very rudimentary training and incomplete military instruction.

Three years previous to the war, under the forceful impulsion of General Leonard Wood, quite a number of citizens' training camps had been organized throughout the country. The first of these had been instituted at Plattsburg, New York, and there during the summer months a large number of volunteers authorized by the department commander went in for military training. The period of instruction lasted thirty days, the course consisting of intensive elementary training for infantry, cavalry, field artillery, and engineers. Students who had attended one or more camps were used as non-commissioned officers or as subalterns and were given more advanced instruction, including the knowledge required by administrative staff officers. The plan soon proved very successful and a large number of college students over eighteen years of age and young business men attended the camps for periods of a month or more. The War Department decided, very soon after the breach with Germany, as a first step toward the solution of obtaining ing the war; 747 came directly from civil life' and 933 from West Point, the Regular Army, the Philippine Scouts, and the National Guard. 
officers for the new army that it would institute a three months' course of intensive training in camps modeled in general on the Plattsburg idea.

Fifteen training camps were accordingly established for candidates seeking commissions. The first series of instruction began on May 15 th. The camps were distributed through the entire country in order not to oblige the participants to undertake too long a journey. Each camp was prepared to receive 2,500 candidates either from the Officers Reserve Corps, selected enlisted men of the National Guard and the Regular Army, or civilians who possessed certain educational qualifications.

The officers of the Reserve Corps accomplished their time of service in camp either as instructors or as students according to the extent of their military preparation, and were subject to regrading or to discharge.

Upon completion of the course of instruction both officers already holding commissions in the Reserve Corps and candidates were recommended by their commanding officers for appointment to such rank as their services seemed to merit. During the first five weeks, training was the same for all and the instructors took special pains to observe the aptitude shown by each individual. After this period, there was a redistribution among the organizations in each camp with a view to special training in the different branches of the service. At the same time, eight of the camps designated a number of candidates who were transferred to Fort Monroe and Fort Winfield Scott, for further instruction in coast artillery.

The engineer companies were likewise concentrated in three camps devoted especially to the training of candidates for commissions in that branch of the service.

Led by the experience of the foreign armies during the 
first years of the war, the instructing officers made a special point of teaching their pupils to be successful instructors, administrators, and leaders - in short, to become thorough-going officers.

The schedules of instruction for all camps were prepared in the War Department and prescribed a minimum number of hours per week for each specialty. Latitude was thus given to camp commanders for the most practical adjustment of their program. The schedule was based on a minimum day of ten hours and a week of five days.

The first series of such periods of instruction terminated on August I 5 th, when 27,34 I candidates received commissions, most of these being at once appointed in the infantry, cavalry, field artillery, coast artillery, or engineers. ${ }^{17}$

In order to provide some of the staff departments with officers who had some basic military training, candidates possessing business experience, or such as would qualify them for service in the quartermaster corps, adjutantgeneral, and ordnance departments were commissioned in those branches of the service.

Some few recently promoted officers were at once sent to Europe in order to supplement training in French and British schools, then to return and serve as instructors at home.

The Secretary of War summed up as follows the work accomplished in the American training camps:

"A more salutary result would be impossible to imagine. The trained professional soldiers of the army received this great body of youthful capacity with hospitality and quickly impressed upon

17 On leaving camp the officers appointed were commissioned as provisional officers in the regular service; 2 colonels, I lieutenant-colonel, 


\section{The American Army in the European Conflict}

it a soldierly character. The young men brought to their training habits which they had formed for success as civilians, but which their patriotic enthusiasm rendered easily available in new lines of endeavor for the service of the country. They brought, too, another element of great value. They were assembled from all parts of the country. They were accustomed to the democracy of the college and high school; they recognized themselves as new and temporary adventurers in a military life; and they therefore reflected into our military preparation the fresh and invigorating atmosphere of our commercial democracy. This has undoubtedly contributed to the establishment of a happy spirit which prevails throughout the army, and has made it easy for the young men chosen under the Selective Service Act to fall in with the training and mode of life which the military training camp requires. An effort was made by the department as far as possible to assign these young officers to the training of troops assembled from their own homes. By this means a preëxisting sympathy was used and admiration and respect between officer and man was transferred from the home to the camp."

The excellent results obtained from these periods of instruction led the government to institute a second series beginning August 27, 1917, in anticipation of the need for officers to take charge of subsequent levies of troops. 72,9 I 4 candidates presented themselves, of whom 21,000 were admitted; 17,237 finally graduated and received commissions.

In January, I 9 I 8, a third course of training was begun; but at this time the divisions of the Regular Army, the National Guard, and the National Army were organized and had been in training for several months.

It became, therefore, possible to select from these units certain candidates for commission among the troopers who had shown natural military aptitude. Ninety per 235 majors, 3,722 captains, 4,452 first lieutenants, 18,929 second lieutenants, making a total of $27,34 \mathrm{r}$ officers. 
cent. of the candidates were chosen among the enlisted men of the army and the other ten per cent. from civilians of draft age who had received military training at recognized educational institutions.

The course was prolonged two weeks in order to admit of a more thorough administrative instruction, and the men who had given complete satisfaction during the course of this last period were at the close of it commissioned as second lieutenants.

Thus the American Army had procured in a minimum time 57,307 officers.

They were distributed as follows:

Field Coast

Ar- Ar- En-

Infantry Cavalry tillery tillery gineers Divers Total

Lieutenant-

Colonels .
Majors .... I 18

Captains ... 3,379

Lieutenants.. 7,665

Second Lieu-

$$
\begin{array}{rrrrrrrr}
\text { tenants } & .23,346 & 1,371 & 8,540 & \text { I,1 1 } 8 & 750 & 4,042 & 39,207 \\
\text { Total } & . .34,578 & \text { I,898 } & \text { I1,554 } & \frac{2,053}{1,966} & \frac{5,248}{57,307}
\end{array}
$$

A fourth course was begun in twenty-four instruction camps with a view to securing i 3, I 4 more candidates for commission. These camps were opened in the training areas of the divisions of the National Guard or National Army who were grouped in anticipation of receiving orders for embarkation.

These schools formed a part of each division, which latter furnished the pupils.

Under the original plan, the school was to accompany 
the division when it moved overseas; but, owing to the urgent need of line officers, these training centers were separated from their divisions and five schools were established at permanent replacement camps for candidates of such divisions as were scheduled for early overseas service. Three of these central training schools were for candidates for commission in the infantry, one for those of the field artillery, and one for those of the machinegun units. Two more centers were added in order to take in candidates for infantry commissions and another also for cavalry.

Instead of one class graduating every three and a half months, arrangements were made for a new class to enter the central schools every two weeks, so that there would be practically a continuous flow of line officers available for replacements or for assignments to new units as they were organized.

On November I, I9I8, there were approximately 46,000 candidates in these schools.

A center of instruction for colored officers was organized in Fort Des Moines, Iowa; others were created at Porto Rico, in the Philippines, and the Hawaiian Islands.

An idea of the American effort in view of obtaining competent officers for the army may be secured by grouping the information contained in this chapter with that concerning the measures undertaken in France by General Pershing to continue this work.

Each of these separate efforts was necessary to bring about the desired end; namely, the rapid and efficient training of a hitherto inexperienced body of officers who were thus enabled to conduct a new warfare upon foreign soil. 
It now remained to group the fighting units.

In the early days of the war it had been decided that organization work in America would be limited to the formation of divisions. Upon his arrival in France General Pershing was to give his government the benefit of advice concerning the organization of that army which he was called upon to command.

The composition of the division, undertaken in the United States, was to be uniform; and was to comprise two brigades of infantry of two regiments each and a brigade of artillery consisting of three regiments.

It was at first expected to organize divisions of regular troops numbered from I to 25 , divisions of National Guard numbered from 26 to 75 , and divisions of the National Army forming a series from 77 to 9 I. $^{18}$

The First Division, made up for the most part of regular troops, was grouped together on the wharves previous to departure, having never up to that time been entirely assembled. The Second Division also was made up of units already existing in peace time but, like the first, never occupied a divisional camp in America, being grouped together only on French soil. It included a brigade of marines and a brigade of regulars.

In order to form the other divisions, vast camps were established, each one with a lodging capacity for 40,000 men or more.

Sixteen of these military cities were reserved for the troops furnished by the draft, sixteen others for the National Guard divisions, the latter of whom, assembled at first in their own States, were given preliminary training in local camps under the supervision of the generals

18 The Ninety-second and Ninety-third Divisions which came to Europe were composed of colored troops. 


\section{The American Army in the European Conflict}

commanding the different departments. In the month of September, 1917, they began to pour in great numbers into the camps prepared for their reception by the Federal authorities.

In the same month, the recruits sent directly from the local incorporation boards, began also to reach the divisional training camps.

As to the regular divisions - not to speak of the already mentioned First and Second - they were sent for training into those camps which had been occupied and left vacant by the units of the National Guard and the National Army which had been the first to embark for France.

Once assembled in these training centers a long wait, sometimes of many months, was imposed upon most of the divisions on account of the shortage in sea transportation facilities.

This time was not, however, lost, but on the contrary was employed in valuable instruction for officers, noncommissioned officers, and men. Under the guidance of their own chiefs and with the advice of prominent technicists in every branch of the service furnished by the French and British armies, the Americans underwent strenuous drilling exercises and became adept in the use of most of the weapons which serve in modern warfare.

A number of American officers, among whom were included the generals commanding the divisions which were in training, came over at this time for a short period of actual experience at the front.

The program to be followed was drawn up for the division training camps by the training section of the General Staff in Washington which remained in close touch with the headquarters of the Expeditionary Forces. ${ }^{19}$

19 See Chapter II, Methods of Instruction. 
Unfortunately there was a serious shortage in the equipment necessary for the conduct of modern war. This shortage applied to practically all kinds of equipment, including rifles, machine guns and trench mortars. The lack was most felt, however, in artillery, aviation, and tank material.

The difficulties in regard to rifle shortage were solved by the issue to National Army divisions of the old KragJörgensen rifle of which there were several hundred thousand on hand until the model I9I 7 rifle which had been adopted began to be produced in sufficient quantity, October and November, I9I7. The artillery material with which the American Army had been equipped was allotted, as far as available numbers would permit, to all artillery organizations, so that usually each regiment had a few guns with which to begin training. Where this was not practicable, as in the case of the heavier field types, wooden models were made by the organizations for training purposes. Similar expedients were resorted to in the case of trench mortars, both light and heavy types. The problem of equipment for machine-gun and automatic-rifle training was solved in part by obtaining a variety of these weapons in addition to a number of Benet-Mercier, Colt, Maxim, and Gatling guns already on hand. Those so obtained included Chauchat rifles and Hotchkiss machine guns from the French, and Vickers guns from the British.

Prior to their entrance into war, the United States Army comprised only nine regiments of field artillery. Under the provisions of the National Defense Act, this number was increased on May I5, 1917, to twenty-one regiments. The National Guard was likewise lacking in a large number of artillery organizations. In order to 
remedy this, cavalry regiments of the Regular Army and infantry regiments of the National Guard were converted into field artillery units. Naturally, the great shortage in artillery equipment was felt particularly in these organizations the personnel of which had had no experience in this branch of the service.

The materials - cannons, mortars, airplanes - sent from France and England for training purposes were not always as numerous as desired and a great many were of antiquated types.

Other schools and other units for specialists were created as occasion arose, and formed by the War Department.

We have thus seen in a general way how the mobilization and constitution of divisions was carried out in America and how the instruction of these improvised forces which were soon to play so important a part in the European battle-fields was undertaken.

For us Frenchmen the term mobilization has a more extensive meaning. It includes not only all the abovementioned processes necessary for the constitution of fighting units, but also the preliminary measures essential for the furnishing of transportation, equipment, horses, and all the supplies requisite to make a military force live, move, and fight.

An account of this series of operations which, in order to become effective, required not only time and money, but also the extensive aid of the Allies who were already engaged in war, will find its natural place in the chapters devoted to the services of the rear and the line of communications utilized in France by the American Expeditionary Forces. 


\section{CHAPTER II}

ARRIVAL OF GENERAL PERSHING IN FRANCE - FIRST PLANS - FORMATION OF THE GENERAL STAFF ORGANIZATION OF FIGHTING UNITS - SELECTION OF ORDNANCE MATERIAL AND OTHER EQUIPMENT METHODS OF TRAINING - CAMPS - SCHOOLS - ESTABLISHMENT OF GENERAL HEADQUARTERS AT CHAUMONT

The S. S. Baltic which left New York on the twentyeighth of May, I9I7, had on board General John J. Pershing accompanied by his hastily improvised staff.

The Allied governments had been informed of his appointment to the command of the Expeditionary Forces, but aside from his name and its associations with recent American operations on the Mexican border, little was known in Europe of the man who was called upon to assume such important functions.

In America, on the contrary, General Pershing was known to all and enjoyed a high and well-earned military reputation in the United States Army.

At the West Point Academy, in the early days of his training, he was equally esteemed and liked by both instructors and comrades. He graduated in i 886 well at the head of his class, of which he was chosen president; a good indication of popularity as well as ability.

$\mathrm{He}$ had selected the cavalry as his particular branch of the service, and, after graduation, he made a reputation 


\section{The American Army in the European Conflict}

as an active campaigner in the Indian country scouting over the plains and mountains of New Mexico, Arizona, and Montana.

He was particularly successful in coping with the frequent Apache outbreaks and was not only remarkable for his untiring work on the trail but also gave proof of great tact and diplomacy in dealing with that warlike tribe. His excellent services soon brought him under the favorable notice of such veteran Indian fighters as General Nelson A. Miles and associated him with the galaxy of officers who surrounded him - both on the plains and in the Spanish War - Lawton, Leonard Wood, Hugh E. Scott, and many others.

In 1896 we find him detached from his command as military instructor in the University of Nebraska, and there while teaching his own course, he became at the same time student of law in this college and was admitted to the State bar. In consequence of his successful work he was designated as instructor at West Point in the tactical department, remaining until the outbreak of war with Spain at which time he asked and obtained leave to participate in action with the Tenth Cavalry regiment. After the attack on San Juan Hill he was cited by his colonel as the officer of the regiment who had shown the greatest coolness under fire.

At the termination of this campaign, he was entrusted with the organization of the "Bureau of Insular Affairs" under the direction of the War Department. He subsequently applied for colonial service and was sent to the Philippines. There he remained at the conclusion of his period of service, and took command of the troops participating in the campaign against the Moros.

Having made a complete success of this enterprise 
which brought him considerable celebrity, Captain Pershing was at once proposed on his return to Washington for the rank of Brigadier-General; the proposition was not seconded, but his talents having been generally remarked there was no hesitation shown in confiding to the young officer the post, which circumstances rendered extremely important, of military attaché in Tokyo whence, in the capacity of observer he was able to follow all the operations of the Russo-Japanese War.

In 1906 Captain Pershing obtained his stars.

He was once more called upon to return to the Philippines, where he was shortly appointed governor of the province of Mindanao, with very extensive powers; during the exercise of these functions he showed himself a most patient and able administrator. To his initiative and organizing capacity are due many roads, schools, and hospitals established in that province.

Then, we find his name especially connected with the Mexican expedition. Starting at the head of an infantry brigade reënforced by a cavalry regiment, he was soon to take over entire direction of the punitive operations which had been decided upon by the American Government.

The rapidity of his movements was a revelation to those who were aware of all the difficulties of execution entailed by such maneuvers. In twenty-four days he had traversed the State of Chihuahua and had attained the lines of Durango, a distance of five hundred miles through a country where the hardships incident to lack of supplies were immense. Heading a detachment of cavalry and mounted artillery he made a raid of one hundred and twenty miles in forty-two hours.

On returning from Mexico he obtained command of the Southern Division taking in most of the territory compre- 


\section{The American Army in the European Conflict}

hended in the old Confederation and also the southern border States.

The officers who accompanied General Pershing on the Baltic were his aides-de-camp, his chief of staff, and the future heads of the most important among the army services. In London, where they remained but a few days, General Pershing had interviews with the King and members of the government, who had special connection with the military operations then in progress, while his companions, visiting the War Office, profited by their short sojourn to put themselves in touch with the English services which corresponded to the several branches of which each was about to assume the direction.

On June $3^{\text {th }}$, at about five in the afternoon, General Pershing arrived in Paris, where he was met by a popular manifestation as remarkable for the warmth of its enthusiasm as by its spontaneity, for the first news of his arrival was only made known through the evening papers of the same day.

On leaving the Gare du Nord accompanied by $M$. Painlevé, Minister of War, and Marshal Joffre, he was the object of a magnificent ovation, which continued all along the route up to the Place de la Concorde where he was to take up his residence. He was acclaimed by the Parisians with an emotion as intense as it was sincere.

The offices of the American headquarters had been installed on the Rue de Constantine near the Invalides, and there, on the morning following his arrival, General Pershing went to work upon the plans which were to govern the organization of his army. As to instructions he had few or none. His actual duty consisted in taking 
command of the American forces from the moment of their debarkation, to organize them progressively in such a manner that the Allied victory might be rapidly obtained. Thus the plan was apparently simple; its execution, as will be seen, was long, complicated, and difficult.

Two dominant ideas, from the very beginning, inspired all subsequent determinations which the general was called upon to take; and it may be justly said that General Pershing followed out the realization of his ideal with a constancy of purpose which alone ought to earn him the particular gratitude and appreciation of his own country and those of his Allies.

The commander of the Expeditionary Forces was determined to organize them in such a manner as to keep for the army of the United States its national autonomy; he was also determined to instill into this army the offensive spirit in its most ardent form.

$\mathrm{He}$ was well acquainted with the martial qualities and military defects of his compatriots, and he knew that the American citizen, once entered into the career of arms was capable of making an excellent soldier provided he was directed by methods consistent with the development of his warlike virtues. For, as has been excellently said:

"There exists between the military habit and democratic customs a secret link which only war can make apparent. The men who dwell in a democracy have a natural desire to acquire rapidly the material benefits for which they strive, and when acquired, it is natural for these men to enjoy them easily. Audacious, they love to risk, but most of them fear death less than penury and suffering. In this spirit which directs their industry and commerce and which they carry with them on the battlefield, they are moved readily to expose their lives, to assure by doing so the fruits of victory. There is no success which is so 


\section{The American Army in the European Conflict}

striking to the imagination of a democratic people as military success, for it is achieved rapidly with brief and concentrated effort and with no risk but of life.

"Thus while their ordinary tastes and customs incline the citizens of a republic to avoid the military career, their manner of thought prepares them to wage war well. And once uprooted from their business habits and their comfortable ways they readily make excellent fighters. Peace is particularly harmful to the army of a democracy; war, on the contrary, assures to such a force advantages unknown to other armies."

It may be supposed that General Pershing understood his countrymen quite as well as Tocqueville eighty years before him, and that he was aware that the American farmer, of simple life, laborious habits, and often subject to severe privations, would necessarily make an energetic and uncomplaining soldier. As to the commercial and industrial elements furnished by the business centers, they also inspired his full confidence; while perhaps more difficult to handle than the contingents from rural districts they shared in the same spirit of ambitious independence and moral energy. The most important thing was to develop these qualities along military lines and the most indispensable element to this development was that the new formations should be officered under a competent command.

The general-in-chief had decided to profit by the experience of the Allies and to take their council, if need were, but he was quite determined, also, to reserve the right to judge in what manner he would adapt, for the profit of his army, the conclusions suggested to him by the veterans of the war.

A close study of the reports which had come under his attention, and a rapid inspection of the French ports, com- 
bined to make the general at once adopt all the conclusions that had been reached by the American military commission which had preceded him in this journey. Consequently, St. Nazaire first and Bordeaux second, were chosen as the harbors which were to be used for the debarkation of the American troops. He also approved the choice of railroads which were to supply the armies, but this latter with one reserve, that the lines chosen would be those best fitted to reach that part of the front ultimately entrusted to the American troops when they should come into action; for at this date the destination of the American forces was not definitely settled.

The general was therefore naturally impatient to decide with the commander of the French forces upon the scene of operation where his armies would be called upon to act.

While his staff and services were getting in touch with their corresponding bureaux in Paris - where the Ministry of War, according to the instructions of $M$. Painlevé had opened wide its doors to receive them General Pershing was frequently on the road to Compiègne in order to consult with General Pétain over the plans and projects governing the organization and ultimate engagement of his armies.

Let us attempt to set before the reader one of these first interviews. The circumstances are yet sufficiently fresh in the minds of every one to make it unnecessary to dwell upon the emotional gravity of this encounter.

The French commander found himself in a position which his knowledge of the actual situation made it impossible for him to embellish by any spirit of optimism. Even had he wished to remain under any illusion as to 


\section{The American Army in the European Conflict}

the possibilities which were confronting him, the great map which hung before his eyes behind his office table would have reminded him at every instant of the immensity of the task before him and the dwindling resources at his command.

From Belfort to the Oise, the enemy's trenches were still plentifully manned, and it was evident that, if Russia retired from the combat, the German troops, released from their positions in the East, would swell the ranks of defenders already in line.

This living wall, which the map displayed to our general, had already once been broken by him, and by him only at the head of his thirty-third corps at Carency on the ninth of May, 19 I5, but might it not now and almost any day move forward to the capital, and how could the present menace, increasing daily with the growing strength of the adversary, be effectively met and countered?

The offensive ardor which was a natural instinct as well as a military precept with our chief was completed by his clear and logical reason, and he could not disguise from himself that the situation of the effectives under his command - known better to him than to another - was grave indeed. His thoughts were thus constantly brought back from the domain of speculation and desire to grim realities.

The victory which he was bound to attain could be won only when he had fashioned the instrument. How could he foresee the day of its completion, now that he possessed neither the adequate number of infantry nor yet an artillery which by its massed fire was capable of protecting the approach and seconding the attack of the foot soldier? This theory of powerful concentration of fire he had him- 
self demonstrated at the War School with as much ability as conviction.

While the forces under his command were gradually preparing for an offensive, following their instruction in training camps, in the trenches, and even on the battle-fields, but with limited objectives, while waiting the time when the arms and munitions supplied by the interior should arrive in sufficient numbers, their chief was seeking to fix the propitious hour, the advantageous ground for a decisive assault.

It was on one of these days of anxious waiting and of unremitting labor that General Pershing appeared at Compiègne, and with him the French commander saw arriving at the same instant the possibility of attack. Memorable indeed was the day on which these two men met. The American gifted with the best qualities of his young and freedom-loving race, with vigorous and practical sense, explained his conception of that organization which he was determined to create. The Frenchman, with the penetrating mind of the precisian, the acumen of the expert tactician, and the flexible logic of the man of learning, bent his wisdom and his experience to measure this new and unknown force which came armed to him from the New World.

He saw this force now incarnate before him in the person whom he addressed. Clean-cut and expressive of feature, tall and broad-shouldered, with the curt, incisive gesture common to the man of action, impatient with the effort of expression in a foreign tongue, and of transforming his thought into activity, General Pershing's energetic profile recalled the line of that bronzed and warlike figure of the Venetian Colleone with clenched fist; typical, also, of those stalwart American men of his, whose sinewy 


\section{The American Army in the European Conflict}

hands would soon be closing upon their fixed bayonets.

In spite of all barriers made by disparity of language, of habits and method, these men were predestined to comprehend one another and had many points of mutual contact. Both shared the same clear-headed prudence and powerful mind, both were dowered with resolute perseverance and indomitable will, both had the inherent love and practice of hard and constant work, the same disregard for undeserved criticism, the same horror of popular outcry and party intrigue.

The friendly collaboration of such a pair was therefore certain to be close and its results epoch-making.

The decisions taken during those first interviews were far-reaching and solved many difficult questions, even those of the still distant future. Later on events fully justified all these initial determinations. Events also justified the truth and appositeness of the formula which terminated one of their conversations, the application of which brought about victory: "A defensive strategy until the Americans are ready to come into line."

After General Pershing had developed his conception of a great American army, described the means which the United States were to furnish, and formulated the hopes which he founded upon the dates of the debarkations, came the time when it was necessary to study the map, in order to determine upon the future zone where our new associates were to operate, and here the choice was necessarily made by the process of elimination.

It would have been impossible to change the sector which the British held from the Channel up to the Oise where for three years they had worked on constructions of all sorts; this region was also in line with their supply base. 
From the Oise to Verdun there were various sectors, but this ground might at any moment become an immense battle-field, and it was impossible to count at that part of the front upon the fixity of the lines. ${ }^{1} \quad$ It was, of course, essential that the first American experiments in arms should be begun in a relatively quiet trench sector which could guarantee the stability of its defense.

On the other hand it was quite indispensable to keep the territory about Paris free and the railroad lines uncongested, in order to permit maneuvering in case the enemy should succeed in breaking through, and in threatening the capital.

The mountainous region of the Vosges presented the drawback of forcing the new soldiers to practice a warfare of a very special nature which was calculated to unfit them for those battles which later would probably take them in to open ground.

There remained the Lorraine front, which seemed to be more favorable to the needs of the American army. This region possessed large plains of sufficient extent to permit of preparatory infantry maneuvers and sufficient high ground to allow the artillery to make use of observatcries.

Saint-Mihiel presented a tempting salient for decisive attacks at the moment when the American forces might be expected to arrive in great strength. ${ }^{2}$

General Pershing was inclined to favor the choice of this sector after a careful consideration of the results of his study of the line of communication. As we have

1 The French armies had already taken the offensive several times on certain portions of this front.

2 The operations for the taking of St. Mihiel were discussed during one of the very first interviews between General Pershing and General Pétain. 


\section{4 \\ The American Army in the European Conflict}

seen, it was essential to seek a point for the eventual abutting of the American effort in a region directly in line with the American railroads and maritime bases.

It was also decided that the French command in the front zone, and our war ministry in the rear should place at the disposal of the American armies a number of camps in proximity with the lines of communication, which would make it possible to complete the instruction of the divisions arriving from the United States before coming into line.

The village of Gondrécourt with its outlying districts was chosen for the infantry of the first division. In the meantime the artillery of this same division was to proceed to Valdahon (near Besançon) for firing practice. This training ground was a little far from the American railway lines, but possessed the advantage of having barracks and other installations which could at once be utilized.

The two commanders-in-chief frequently met to exchange their views upon the methods of instruction which were to be enforced. And while waiting the time when General Pershing could dispose of a sufficient number of well-drilled officers indispensable for the training of his troops, the French command arranged to detach from their ranks an entire division which might serve as guide and model to the first American unit which had disembarked. They also agreed upon the eventual manner of placing the American troops in line when their instruction should be complete.

No time was lost in following up all the decisions upon which General Pétain and General Pershing had reached an agreement in order to set the American contingents to work from the very moment of their landing. One of 
the most pressing questions was the constitution of a General Staff.

Up to this time the American army regulations had not foreseen more than three sections among which the entire constructive labor of the field armies was divided. The first was the Bureau of Operations, the second that of Information, the third directed the general Administration of the army. Such a division of work had now become inadequate for a General Staff of such importance as that of the Expeditionary Forces.

After thoroughly studying the working of the French "Grand Quartier" and the British general headquarters and weighing the particular conditions in which the American army would be placed, General Pershing decided to form his staff along the following lines:

At the head was placed a chief of staff $^{3}$ holding the rank of major-general, assisted by a deputy chief of staff ${ }^{4}$ when active operations were in progress. Five sections were to be created, each one having at its head a brigadiergeneral. These sections were charged with the arrangement and organization as follows:

First (known as G-I): Organization and equipment of troops, effectives, replacements and remounts, questions regarding tonnage and priority in ocean transportation, and military benevolent associations. ${ }^{5}$

Second (known as G-2): Intelligence service, censor-

${ }^{3}$ The first chief of staff of the American Army was General James G. Harbord. He was succeeded on the fifth of May, 1918, by General James W. McAndrew.

4 General LeRoy Eltinge was appointed deputy chief of staff on May $\mathbf{r}$, 1918.

5 Colonel James A. Logan was first chief of this section. He was succeeded by General Alvery D. Andrews on August 21, 1918. 
ship, secret-service, counter-espionage, circulation, and map section. ${ }^{6}$

Third (known as G-3): Military operations, strategical study, plans, orders, reconnaissances, location of troops, concentrations and liaison with the armies in active operation and the allied armies. ${ }^{7}$

Fourth (known as G-4): Supplies, transportation, labor, statistics, hospitalization and evacuation, distribution of the units arriving in France and employment of operatives. $^{8}$

Fifth (known as G-5): Principles and methods of instruction, training centers, schools, manuals, and regulations. ${ }^{9}$

This last-named section, which does not exist in our French staff or rather which is subsidiary to the operation section, was destined to be extremely important to the American Army.

General Pershing did everything to extend the activities of this section whose rôle was not only to supervise the general instruction of the troops actually in France, but also to advise and determine the courses followed in the United States.

There exists in the American staff bureau an instrument which our French service lacks. This is the function of the adjutant-general. ${ }^{10}$

${ }^{6}$ This section remained during the whole war under the direction of General Dennis E. Nolan.

7 The first chief of this section was Colonel John McA. Palmer. He was succeeded in the early days by General Fox-Connor.

8 This section was at first headed by Colonel W. D. Connor, who was in turn succeeded in May, 1918, by General George Van H. Moseley.

9 This section was commanded by Colonel Paul B. Malone, who in February, 1918, was succeeded by Harold B. Fiske.

10 The first adjutant-general was General Benjamin Alvord. He was succeeded, when he left France for America, by General Robert C. Davis. 
The commander-in-chief of the American forces gave to this function a very important rôle.

The adjutant-general is entrusted with the current work, the keeping of archives and books, the registration and formulation of administrative orders, the settlement of the questions of personnel, the examination and establishment of promotion, individual notes, printing service, identification cards, prisoners, and recruiting. The adjutant-general keeps in constant touch with the commander-in-chief and the chief of staff with whom he remains in intimate relation. He participates in their mess, prepares and registers a large part of their correspondence, and attends to the important service of the cipher with Washington. In short his rôle is that of a coordinating link between all the staff services. The adjutant-general in Chaumont employed some 58 officers and 700 men.

Naturally the great importance of the department was largely due to the fact that the American Army was operating far from home. It was therefore necessary for General Pershing to assure through his staff a number of those services which in the French Army are undertaken by our Ministry of War.

The constitution of fighting units was now the principal preoccupation of the American high command during the days of preparation.

Herein General Pershing gave his preference to a system which, while perhaps less elastic than our own, was more prudent and practical considering the great distance which was to separate the future combatants from their original base. He intended to place in the front line units sufficiently strong both in troops and material to be 


\section{The American Army in the European Conflict}

able to maintain themselves for a considerable time without constantly calling for fresh supplies and reënforcements. In comparison with French units, depleted by four years of warfare, we may compute that the formations of our new ally were about double the strength of our own.

The army corps was formed with six divisions. Four of these were to be employed in active service, one was for replacement, one for depot. The army corps also included some non-divisional units, practically forming a total of 6,050 officers and i 70,000 men.

It must not be supposed that this formation of the army corps was absolutely rigid and immutable, and one in which General Pershing admitted of no modification; on the contrary, the constitution of the army corps which we have described had as a principal object to supply a permanent base of computation for the calculations necessitated by the priority schedules. In this manner the proper number of troops with their auxiliaries could be reckoned upon by the transportation experts.

The commander-in-chief had, as we have said, closely observed the methods employed by the French and British for the handling of their fighting units, especially those which were engaged in active operations, and he was fully persuaded of the desirability of forming an organism which would not be too rigid nor too unwieldy for the exigencies of modern warfare.

Later on the divisions which had at first been denominated " replacement divisions" were used like the others as fighting units, and the army corps, as in France, was transformed into a merely tactical organ. As for the depot divisions, they became a sort of a reservoir furnishing the fighting units with men and officers to replace 
those whom illness or the enemy's fire had forced to leave the first lines.

The non-divisional elements of the army corps included about 500 officers and I6,000 enlisted men organized as follows :

One brigade of corps artillery (usually that of the depot division), consisting of one regiment of I 55 heavy guns and one of 4.7 inch guns, of American manufacture or else two regiments of 155 .

One battalion of trench artillery consisting of four batteries of $240 \mathrm{~mm}$.

One battalion of four batteries of auto-cannon for antiaircraft defense.

One machine gun battalion for the same purpose.

Two cavalry regiments.

One regiment of infantry pioneers.

One engineer regiment.

One field signal battalion.

One telegraph battalion.

One detachment of pontoniers; besides trains (ammunition, quartermaster, etc.) and aviation units of which the number varied according to need.

The American division consisted of 979 officers and 27,080 men; it included :

Two infantry brigades.

One brigade of field artillery.

One battery of trench mortars.

One engineer regiment of two battalions.

One field signal battalion.

One motorized machine-gun battalion of two companies and a certain number of trains and services.

Thus constituted the division seemed well fitted for 
action. Nevertheless this unit, to be well employed, had to be engaged under certain conditions. Its artillery was not sufficiently powerful to cover a wide front; but on a narrow one - two miles for instance - the infantry was numerous enough to be echeloned in depth and thus allow a vigorous attack or permit a long resistance.

The infantry brigade was composed of 246 officers and 8, I 69 men. It included a staff of 4 officers and 20 men, a machine-gun battalion of four companies, and two infantry regiments.

The infantry regiment was formed of three battalions, a machine-gun company, ${ }^{11}$ one headquarters company, ${ }^{12}$ and a supply company. It numbered II 2 officers and 3,720 men.

The infantry battalion had 26 officers and I,000 men and contained four companies.

The infantry company comprised 6 officers and 250 men; it was composed of a small headquarters detachment of 18 men and four platoons of 58 men each.

The divisional artillery was formed by one brigade of three regiments of two or three battalions each.

Two regiments manned each twenty-four cannons of $75 \mathrm{~mm}$. and possessed two battalions of three batteries.

One regiment manned twenty-four cannons of i $55 \mathrm{~mm}$. howitzers and possessed three battalions of two batteries.

Thus formed, the brigade effectives comprised 208

11 The American machine-gun company includes 6 officers and 172 men. It is composed of three platoons of four machine guns and disposes of four spare guns.

12 The headquarters company includes 8 officers and 336 men distributed among five platoons, i.e.: one regimental and battalion headquarters platoon including the band, one platoon of telephonists and signalers, one platoon of sappers - bombardiers, one platoon of pioneers, one platoon of three $37 \mathrm{~mm}$. guns. 
officers and 4,769 men. The brigade disposed also of 3,883 horses.

The trench-mortar battery of the division numbered 5 officers and i 63 men.

Command of tactical units was organized along the following lines :

The regiment was commanded by a colonel assisted by a lieutenant-colonel.

The infantry or artillery brigade was placed under orders of a brigadier-general, whose staff consisted, if infantry, of 5 officers and 20 men; if artillery, of 9 officers and 54 men.

The division was commanded by a major-general, whose staff consisted of 40 officers and 200 men.

The staff comprised:

A chief of staff of the rank of colonel.

Three field officers, chiefs of supply, information, and operation.

Three aërial observers.

One inspector general of the rank of colonel charged by the division commander with inspection, investigations of all kinds concerning the instruction of troops, maintenance of equipment, and administrative accounts.

One adjutant-general, a field officer whose duty was to assure the distribution of orders, to keep the archives, and furnish stationery and other accessories of the office work under his supervision.

One judge-advocate charged with the duties appertaining to the department of military justice besides those concerning all questions of claims and indemnities in which matters he acts toward the general in command of the division as legal adviser. 


\section{The American Army in the European Conflict}

One gas officer.

One officer of the signal corps.

One machine-gun officer.

One division chief of engineers who is the colonel in command of the regiment of engineers belonging to the division.

The army corps was under the command of a majorgeneral disposing of a staff of 54 officers and 4 I 5 men.

This staff comprised one chief of staff of the rank of brigadier-general and all the same chiefs of sections and of services as in the staff of a division, with the exception of the machine-gun officer.

In less than a month after arriving in France General Pershing was ready to submit his organization plan to the Department in Washington. It was put into practical effect with very slight modifications.

His projects included the ultimate formation of a field army, on the organization of which he reserved his decision. But in order to have the necessary elements at hand when the time came, he requested that space might be reserved in the priority schedules for the transportation of the army services.

Certain derogations made later in the original plans of the American headquarters caused the delay in the arrival of the field army services. But we may already give a general idea of their prospective organization.

Their staff was to comprehend a number of sections corresponding to those of general headquarters. The army corps and other component parts of an army such as aviation, engineer, and artillery units were to vary in number. Each field army was to contain powerful artillery formations including several brigades of $155 \mathrm{~mm}$. 
(6 inch) guns, and several brigades of 8 and 9.2 inch howitzers, motorized regiments of French $75 \mathrm{~mm}$., and brigades of railway artillery or of guns mounted on heavy tractors; for the engineers a regiment of miners, a regiment of water supply service, a regiment of construction, a regiment of electricians, and a regiment of park material operators consisting of six companies.

The signal corps was to furnish a field battalion with two telegraph battalions to each army.

A more complete enumeration of the detachments which each special service was to assign to the field army will be found in Chapter VI.

The selection of arms and ordnance material ${ }^{13}$ was inspired by a close study of the French and British experience since the beginning of the war, when the choice was not imposed by the conditions of manufacture. For often it became necessary to adopt certain models already at hand, whether in the case of rifle, machine gun, or cannon while awaiting the manufacturing of more perfected weapons.

The American infantryman was equipped with the model I9I 7 rifle whose weight was practically the same as the French one. Somewhat shorter than the latter it was terminated by a knife bayonet also considerably shorter than ours.

The automatic rifle which the American army utilized at first was the French Chauchat. Later, the units arriving from America were supplied with their own automatic

13 The clothing and equipment of the American Army were not modified to any appreciable extent during the war. The British helmet and overseas cap made of olive drab were substituted for the felt hat and the garrison cap. Each man received a gas mask. 
Browning, firing a cartridge turned out in the United States. This weapon is lighter than the French automatic rifle, 15 lbs. instead of 2 I lbs. Its filler holds 20 cartridges. It can fire either one shot at a time or else automatically.

The American divisions used two sorts of machine gun, the Vickers and the Hotchkiss models, which gave place before the war ended to the Browning water-cooled machine gun, and lighter by a third than the French mitrailleuse ( $36.8 \mathrm{lbs}$. as against $52 \mathrm{I} / 2 \mathrm{lbs}$.).

Both these Browning weapons, the machine gun as well as the automatic rifle, were manufactured in large quantities and calculated to replace progressively the other weapons which had been distributed in the opening days of hostilities. Thus the question of supplying ammunition to the American units was greatly simplified since, toward the end, there was only one kind of cartridge in use among the American infantry.

As to the artillery material of all kinds, almost everything was supplied by the French ordnance department up to the time when the United States should be ready to modify their machinery for the manufacture of the cannons adopted by the army.

It had been decided to supply the light divisional batteries with our French 75 model, which was able to fire a projectile weighing 13 lbs., .7 a distance of five miles and a quarter and of which the excellent practical working was well known. The heavy batteries received the 155 $\mathrm{mm}$. howitzer, system Schneider, firing a shell weighing I 7 lbs. to a distance of seven miles.

Although it had been foreseen that these heavy divisional batteries might be motorized they nevertheless remained dependent on their horses as formerly. 
The artillery of the army corps was supplied with a 4.7 inch gun (American) which carried about six miles, and whose shell weighed Iog lbs. and also with our I 55 long, known as the great power I 55 system Filloux, firing a I Io lb. shell to a distance of ten miles.

As to the artillery of the field army, it had been arranged that it should use the 155 long (great power) and also American cannons of 5 and 6 inch firing, at a maximum distance of about nine and eleven miles, shells of $46 \mathrm{I} / 2 \mathrm{lbs}$. and $95 \mathrm{lbs}$. respectively, also English 8 inch mortars ${ }^{14}$ and American mortars of 9.2 inch firing at short distance, about five miles and three-quarters shells of 222 lbs. and 319 lbs.

The divisional batteries of trench artillery used the French 58 mortar No. 2, later replaced by the English Newton mortar of 6 inches. ${ }^{15}$

The trench batteries of the field army were to be furnished with the French 240 while awaiting the manufacture of a similar American weapon.

All the material used for anti-aircraft defense, the 75 cannon as well as the 4.7 inch shortened and with weight reduced, were to be furnished by America.

The principles governing the instruction of the American units were formulated by the fifth section of the staff a short while after the arrival in France of the first American contingents and were immediately approved.

The doctrine thus enunciated during the formation of the army was practically not modified during the whole period of hostilities. The value of the theories which

14 America was supposed to manufacture this gun during the first months of the war.

15 Which was distributed to the infantry. 


\section{The American Army in the European Conflict}

had been thus put into force were absolutely upheld by the military events.

The first instruction program delivered by the American headquarters to the troops who were disembarking read in part as follows:

"The general principles governing the training of the American Expeditionary Forces will be announced from these headquarters. Strict compliance with these principles will be exacted and nothing contrary thereto will be taught. All instruction must contemplate the assumption of a vigorous offensive. This purpose will be emphasized in every phase of training until it becomes a settled habit of thought.

"The general principles governing combat remain unchanged in their essence. This war has developed special features which involve special phases of training, but the fundamental ideas enunciated in our drill regulations, small arms firing manual, field service regulations, and other service manuals remain a guide for both officers and soldiers and constitute the standard by which their efficiency is to be measured, except as modified in detail by instructions from these headquarters.

"The rifle and bayonet are the principal weapons of the infantry soldier. He will be trained to a high degree of skill as a marksman both on target range and in field firing. An aggressive spirit must be developed until the soldier feels himself, as a bayonet fighter, invincible in battle.

"All officers and soldiers should realize that at no time in our history has discipline been so important; therefore discipline of the highest order must be exacted at all times.

"Training will be based on developing sound leadership in succession in the squad or group, the platoon, the company, and finally the higher units."

In the program of training promulgated by the fifth section of the American staff special provisions were made for the drilling of all units in view of open warfare, rather than elaborating the study of trench combat. This was quite according to the personal idea of General Pershing, 
and was impressed upon all divisional commanders, including those who were to return to the United States after completing their tour of observation in France, in order to proceed with the training of their divisions in America previous to transportation. A memorandum to this effect, given to the officers before their return to the United States, is quoted here:

"The disposition to regard the introduction of a variety of new weapons to meet the special conditions of trench warfare as evident of a complete departure from all our former principles of combat should be constantly opposed and the attention of all officers should be fixed upon the ultimate object of all trench operations; namely, warfare in the open conducted in all essential elements according to the principles found in our standard manuals. The doctrine taught by the General Staff of all the great armies in this war confirms this opinion which was naturally considered by the commander-in-chief before its promulgation and will be adhered to by him in directing the training of troops in France."

General Pershing arranged with the Secretary of War that an absolute uniformity of training should be practiced on both continents, and a series of cablegrams between Chaumont and Washington were to make known in America the dominant ideas in vogue as well as any new technical procedures to be employed in France.

In one of these cables the necessity of large spaces for the exercise of troops in the open was dwelt upon.

Thus as may be seen General Pershing brought to all the questions of military instruction an attentive study and gave a vigorous impulsion to his training policies. Certainly his educative influence was profoundly felt on both sides of the ocean.

Nothing is more difficult than to lay down hide-bound rules governing the exact schedule of study to be followed 


\section{The American Army in the European Conflict}

in a specified time, or to set precise dates for the instruction of divisions not yet landed. Moreover some of these divisions came to France with their instruction well under way, others with the merest smattering obtained after a very short stay in the first training camps. It was, however, decided that each division should complete its training in our country during three months and a half, which period was extended later. These training periods were roughly divided in three phases.

During the first phase the training was followed in camps,' artillery and infantry separate. During the second phase, instruction was carried on in the front-line trenches of a quiet sector, the infantry being seconded, when circumstances permitted, by its own guns. The last phase saw the infantry and artillery once more grouped in camp practicing concerted maneuvers with artillery and infantry linked.

The exact duration of each of these phases was determined according to the degree of preparation already reached by the division under observation before quitting America. Before its arrival, each division was preceded by the officer to whom its instructions had been specifically entrusted. This officer was to at once place himself in touch with the Fifth section of the General Headquarters, where the completion of instruction was studied and prepared.

In order to perfect the training of those American units arriving in France General Pershing had recourse to the French and British armies with a view of obtaining instructors.

To comply with these needs, General Pétain detached to the service of the Expeditionary Forces not only officers, non-commissioned officers acting as instructors and 
liaison agents, but also three complete divisions; the Forty-seventh, Eighteenth, and Sixty-ninth, which were to be placed in turn beside the American units and serve as model.

Thus the general ideas having been agreed upon, a doctrine formulated, and certain measures definitely admitted, it was necessary to open more camps and establish centers of instruction in view of perfecting the training of the divisions as fast as they arrived in France, as well as to develop the technical training of the prospective instructors who were to officer the American units.

It will be remembered that General Pershing and General Pétain, as soon as they had arrived at an understanding as to the future zone of action to be occupied by the Expeditionary Forces, decided upon the camp at Gondrécourt for the training of the first division.

It was accordingly in this village and in its outlying districts that the American infantryman established himself after the French manner; that is to say, using as shelter the houses and farms of the rural inhabitants instead of the barracks and tents to which he was accustomed at home.

Other camps were prepared for the troops who were expected to arrive in France in the near future. These were organized around Neufchateau not far from Gondrécourt, but in this region the lodging possibilities were not sufficient to house all of these troops and recourse was had to French and American labor for the construction of large barracks. Similar camps capable each of lodging an entire division, with training ground sufficiently spacious for all maneuvers, were soon to spread over a region comprised between Dijon, Toul, St. Dizier, and 
Joigny so that many called this section of country the "American Zone." There, at the close of hostilities, twenty-one divisional camps could be counted.

The commander-in-chief decided also upon the creation of two other categories of training areas, to be located one near the base ports, for the reception of the depot divisions; another along the communication lines and in close proximity to them for the replacement divisions which it was unnecessary to establish in close proximity to the front.

In all these centers the infantry was prepared for combat according to the plans laid down and programs elaborated by the American general headquarters. Trenches were dug, wire entanglements set up, firing ranges installed, and everywhere an intensive preparation was in progress.

If it seemed relatively easy to provide adequate means of training for the infantry troops it was correspondingly difficult to secure proper facilities for the artillery, which service requires immense spaces for its firing practice.

From the moment that the American participation had been decided upon, the French command had made ready and placed at the disposition of the American artillery the large camp of Valdahon, which was put in order to receive and instruct the artillery of the First Division from the time of its debarkation. Stables were prepared and the polygon arranged to suit the exigencies of modern ordnance. During this preparation General Pershing's officers were being brought in contact with ours.

Various decisions were undertaken and precise rules laid down in order to assure the training of the American artillery troops without loss of time. 
As was stated in a memorandum published July 25 , I917:

"The technical training of the first artillery brigade which is to furnish the future instructors to the American troops is to be pursued according to the French system. When the period is terminated, another will be accomplished at the front. Then the brigade will be returned to its division in order to proceed with its unit to the practice of concerted maneuvers.

"The general commanding the first brigade of artillery will assure himself of the attention given to the above prescriptions and, after studying the results, will make what proposals he deems opportune."

Persuaded that the transportation facilities would be rapidly ameliorated, and that the arrival of the artillery brigades would be effected sooner than had been foreseen in the initial calculations, General Pershing decided to organize other camps and firing ranges at Coetquidan and Meucon in Brittany, and at Souge near Bordeaux.

A stay of about two months was decided upon as the normal time which each brigade would pass in camp. The brigades were expected to arrive in France at the rate of three or four a month. ${ }^{16}$

The installation of these camps was undertaken with 16 The American artillery brigades arrived in Europe at the following rate:
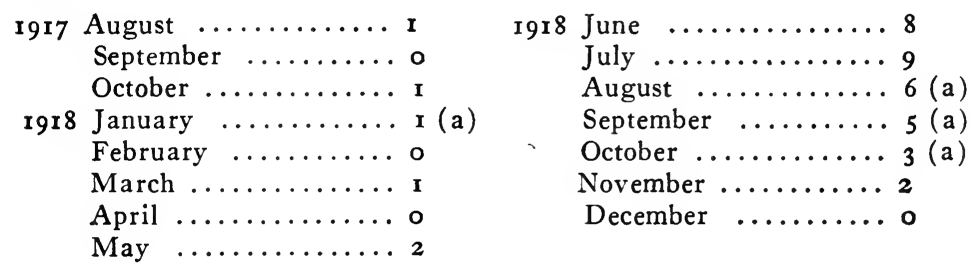

That is to say thirty-three divisional brigades and six army corps brigades.

(a) Included the brigades which had been transformed into corps artillery. 
as much rapidity as the civilian and military labor, together with that furnished by the prisoners of war, permitted. These camps were able to receive respectively: Coetquidan.-A first brigade in October, 19I7, and a second in November of the same year.

Souge.- Two brigades in March, I9I8, and a third in May.

Meucon.-One brigade in March, I9I8, and a second in April.

For some time, when the American artillery was arriving en masse, it was found necessary to utilize La Courtine and also the zones of Ornans, Redon, Bordeaux, Rennes, and Poitiers in order to begin the instruction of the new arrivals while waiting for a place to be vacated in the above-mentioned camps.

Some time later, in July, I9 I 8, it was decided to utilize the camp of Courneau, evacuated by the Russian troops, and the chief of the American artillery raised the number of brigades to be simultaneously instructed at Souge up to three.

These dispositions made it possible to form all the brigades without loss of time.

After the month of October, 19I7, when the first brigade, whose instructions had been directed by French officers, was ready to quit camp, it was already possible to select twelve American officers capable, in their turn, of teaching the new arrivals of the second brigade. Together with a few French instructors a new training nucleus was thus formed.

This method was continued with each divisional artillery and gave excellent results.

It was also necessary to inaugurate training centers for the heavy artillery on tractors (army and army-corps ar- 
tillery). These centers were established at Libourne, Limoges, Clermont, and Angers or in the immediate vicinity of these towns, where from three to four regiments of heavy artillery were placed in cantonments. Schools for the training of drivers were instituted with all the accessories necessary for the pursuit of rapid training.

Thanks to this system of taking a certain number of instructors out of the units whose training had just been completed it became possible for the Americans themselves to aid in the military preparation of the units which were being constantly disembarked. But it was easy to foresee that, as time went on, these instructors would not be sufficient to handle the training of all the American units. It could also be presumed that all the instructors would not be thoroughly inoculated with the principles which the Chaumont headquarters was determined to instill into the troops and their chiefs. Nor could the application of this system provide for the necessary number of staff officers which would be required at the time of the formation of the big units.

Taking also into consideration the lack of specialist training in every branch, it became clear that the best way to meet the difficulties of the situation was the creation of a large number of schools, where, to quote the terms of the report made by the training section at American headquarters, it would be possible to form " a staff officer and a cook as well as a blacksmith."

The plan for the organization of military schools in France had been submitted to General Pershing on August 27, I9I7, and was approved; it was only possible, however, to realize the project by degrees according to the arrival of instructors, material and students. 


\section{The American Army in the European Conflict}

The general plan may be thus summed up:

In each division training went on under the personal supervision of the general in command who exercised control over the schools, and training centers established in his unit.

In each army corps an instruction center to be organized for the purpose of training replacements of all grades and commanders of all units. Each group of corps schools to instruct commanders of proper grades for four combat divisions.

For the entire army in France a center of instruction known as "the army school" to be organized. This group was to include a general staff college as well as other centers for the preparation of instructors who were to perform their duty in the army corps.

These army schools were placed under the direct jurisdiction of the general headquarters in order that the doctrine which would govern the instruction methods and combat tactics might be transmitted from the General Staff through these schools to all units of the army.

For the base divisions centers were to be organized for the training of replacements and classes organized for specialist training.

The army schools were to be established at Langres; those of the first corps at Gondrécourt; those of the second corps at Chatillon-sur-Seine, and those of the third corps at Clamecy.

General Pétain and Marshal Sir Douglas Haig placed a certain number of officers and men at the disposition of the American staff to aid in the formation of instructing bodies of these schools. The German attack during the spring of I9 I 8 made it necessary slightly to modify the instruction plan. Since the army corps were 
called upon to operate at the front and their commanders, in consequence, were unable to maintain a personal supervision over the training centers, which had been confided to their particular charge, it was decided that the Chaumont headquarters should extend its zone of activity in order to include the direction of the army corps schools.

Aside from this slight modification, the system of schooling, such as had been instituted when the American disposed only of 40,000 men on our soil, underwent absolutely no change up to the signing of the armistice, at which time our American allies had more than two million men in France and everything concerning the running of these schools was highly satisfactory.

We shall first examine the list of army schools, then the corps schools, and subsequently the schools for the instruction of specialists.

The army schools were listed as follows:

Army general staff college: established at Langres ${ }^{17}$ opened its doors on November 28 th. It was destined to prepare student officers for the function of staff officers for corps and divisions. The course was of three months' duration. Each class comprised two hundred students from the rank of captain to that of colonel. It was found possible to graduate four entire classes from this school. A total of 777 officers were enrolled during the four courses and 554 of these were recommended for staff duty of various kinds.

The college of Langres was under the supervision of General James W. McAndrew, who was later to become chief of staff of the American Expeditionary Forces.

17 All the schools herein mentioned were established at Langres unless otherwise specified. 
General McAndrew was a specialist in all questions of military instruction; he succeeded in making the army college a model of its kind. He was careful to surround himself with the best instructors that the American, French, and British armies could supply. It may be said that this institution has had an indelible influence upon the fighting methods of the American army.

Army school of the line: For the instruction of captains and field officers in infantry tactics. The course lasted three months. Four classes were graduated, making a total of 497 officers. The first course opened February 4 , I9I 8 .

Army infantry specialists' school: With the capacity of 1,200 students. In this establishment company officers and non-commissioned officers were trained in the use of infantry weapons. Seven separate courses were conducted at the same time. They consisted in musketry and bayonet; automatic weapons; light trench mortars; $37 \mathrm{~mm}$. gun; observation and sniping; grenades; minor tactics. The first term began December I7, 19I7, the length of the course varying from two to four weeks. 3,OI 8 officers and 2,364 non-commissioned officers received instruction at this school during its existence.

Army machine-gun school: Opened December I7, I9I 7 , for the training of officers and non-commissioned officers in the use of machine guns. The course lasted four weeks. Fifteen classes were graduated up to October 26 , I 9 I 8 , making a total of 539 officers and 465 noncommissioned officers.

Army engineer school: Where 300 officers and noncommissioned officers could be trained at the same time in the duties of the engineer troops. This school instructed: 
4,500 officers and non-commissioned officers in the bridge section.

3,000 officers and non-commissioned officers in the camouflage section.

3 , 100 officers and non-commissioned officers in the mining section.

2,800 officers and non-commissioned officers in the pioneer section.

There was originally in this school a topographic section, which was later transferred to the army intelligence school, and a searchlight section, which was turned over to the army anti-aircraft school.

Army signal school: Had a capacity of 400 students. I 79 officers graduated from the section for personnel of mobile units and I 49 from the section of radio operators.

Army sanitary school: Established with a view of training officers of the medical department in the duties of their specialties in the field. The course for dentist covered two weeks and for medical officers five weeks.

5 I 6 student officers received instruction during the existence of this school.

Army gas school: A number of courses were here conducted varying from a two-hour course to a two-weeks' course for officers and non-commissioned officers who were to be used as instructors in the divisions.

The number to pass through various courses was as follows:

\begin{tabular}{|c|c|c|}
\hline & Officers & Men \\
\hline $\mathrm{Tw}$ & $\mathrm{I}, 247$ & 30,9 I 8 \\
\hline cours & $\mathrm{I}, 682$ & $\mathrm{I}, 837$ \\
\hline -day course. & 516 & 8,657 \\
\hline Six-day course. & 473 & 4,577 \\
\hline o-week course & 43 & \\
\hline
\end{tabular}


Center of information for general officers: Was only open at certain periods when the military situation made it possible to group the generals and senior colonels in order to have them assist at lectures and courses on the recent war operations. Two courses only were completed. Thirty-two officers were present.

Center of artillery studies: The object of this course was to develop before the artillery and infantry brigade and regimental commanders the results and lessons contained in the recent operations. The length of the course when the military situation permitted them to take place, was three weeks. Nineteen students only were able to follow them.

Army candidate school: With a capacity of 8,000 students. The course lasted three months, and was divided into three separate sections:

Candidates for commission in the infantry and cavalry.

Candidates for commission in the engineers.

Candidates for commission in the signal corps.

It was originally planned to train candidates for commissions in all branches here, but the increase in the number of officers necessary called for the establishment of a separate school for artillery officers at Saumur and finally a separate school for infantry candidates at Valbonne. A total of I I,952 entered the Langres school. 3,242 (including 65 marines) were commissioned for infantry; 404 in engineers and 222 in signal corps, 2,354 (including 22 marines) infantry candidates, 823 engineer candidates, and 143 signal candidates who completed courses successfully after cessation of hostilities were commissioned in the officers' reserve corps on the active list.

Infantry candidates school (La Valbonne): Could accommodate 2 I,000 students. The length of the course 
was to be three months and the object to instruct selected soldiers for commissions in infantry. The school was planned to have classes of about 5,000 soldiers enter each month. 5,500 men entered with the first class on October I8, I9I8, but with the cessation of hostilities on Norember II th no more classes were started. I, 370 solliers of this first class were graduated and given commissions in the officers reserve corps on the inactive list.

Army field officers' course of two weeks was created to train junior field officers in tactics and infantry weapons. Six classes amounting to a total of 476 officers took this course.

Army anti-aircraft school: With varying capacity and course of from four to eight weeks. This was a combination school and training center of anti-aircraft personnel in gun and machine guns and searchlights. The artillery section handled classes of forty officers and four batteries at a time.

Army intelligence school: Instructed 138 officers in examining prisoners of war and captured documents, also ninety soldiers in restoration of photographs taken from aircraft.

Heavy artillery school: At first installed at Haussimont near Mailly, was soon transferred to Angers, where it was in closer touch with the artillery school at Saumur and where buildings already existing and vacated by the French were suitable for an important center of instruction. Five hundred young officers of the heavy artillery were trained and taught the principles then governing their branches of the service. Those who were to join the railroad artillery perfected their training at the Mailly school while the others detailed to the motorized artillery were sent to Gien to complete their studies. 


\section{The American Army in the European Conflict}

This school also formed a certain number of specialists; orienters, telephone officers, radio officers, who followed a three weeks' course. A special tactical course was also conducted for field officers.

Saumur artillery school: Was open up to the end of March, I9 I 8, for reserve officers, second lieutenants, lieutenants, and captains who arrived from the United States. These officers graduated at the rate of one hundred and fifty a month and were sent to join the artillery brigades while these were pursuing instruction in camps.

In 'March, 19 I8, it was decided to make use of the Saumur school for the formation of artillery officers raised from the ranks of non-commissioned officers and privates. These students came in part from the fighting forces and part from the United States. The average matriculation reached eight hundred a month. The students thus graduated joined (and these were the greater number) some formation of field artillery, the others heavy artillery regiments.

From September, I9I 7, to October, I9I8, Saumur instructed about 4,000 officers.

Tractor artillery school: Allowed 800 officers to perfect themselves in the driving of heavy tractors.

Tank school: Which constituted essentially a training center for the personnel of both officers and men of tank units. It began operations on January 8, i9 I8. The first tanks were received from the French Government on March 23d of the same year. 755 officers and 9,275 men were trained in the various duties of the personnel of the tanks units.

The capacity of the three corps schools was 2,500 offcers and non-commissioned officers each. 
A corps school comprised a group of schools, the functions of which were:

(a) Instruction and training of platoon and company leaders.

(b) Development of instructors in the use and tactical employment of infantry weapons.

(c) Instruction of officers and non-commissioned officers of the special services and of various specialists.

The course of instruction at the corps school at first lasted five weeks, later being reduced to four weeks, and was applied in schools whose curriculum is indicated by their names.

(a) Infantry practical school.

(b) Infantry weapons school.

I. Automatic Rifle Section.

2. Grenade Section.

3. Musketry and Bayonet Section.

4. Sniping, Observation, and Intelligence.

5. Battalion Scout Officers Section.

6. Stokes Mortar Section.

7. $37 \mathrm{Mm}$. Section.

(c) Machine-gun School.

(d) Engineer School.

(e) Gas School.

(f) Signal School.

Aëronautical School (second corps only).

In addition to the foregoing, sanitary schools were conducted for a while in the first and second corps. An aerronautical school was also conducted in connection with first corps schools, but was subsequently discontinued. 
72 The American Army in the European Conflict

The first corps schools began work on October I 5, I9 I 7, and conducted eleven complete courses before being discontinued on December 2Ist, I9I8. I 2,535 students (officers and non-commissioned officers) graduated from the various courses. The second corps school were established in the latter part of January, I9I 8 , and the third corps school began September 2, I9I8. Both the second and third corps schools were still in operation at the time of the armistice.

In addition to the foregoing, the following school or training centers were established where officers and soldiers were given courses of instruction in special branches.

FOR AVIATION

American Balloon School at Meucon.

Course of three weeks for observers (officers).

Course of ten days to two weeks for enlisted specialists (radio, telephone, chart room, winch, machine gunners).

American Elementary and Observation School at Tours.

(Second Aviation Instruction Center.)

Two months' course for aërial observation (pilots).

Three weeks' course for observers.

Third Aviation Instruction Center at Issoudun.

Courses for pursuit and observation pilots.

A three weeks' advance training; a five weeks' pursuit training.

Fourth Aviation Instruction Center at Avord.

Instruction given by "Ecole d'Aviation Française." Course three weeks. 
Seventh Aviation Instruction Center at Clermont-Ferrand.

Training of day bombardment, pilots and bombers. Length of course, one month.

Eighth Aviation Instruction Center at Foggia, Italy.

Training pilots in day and night bombing. Length of course, six weeks.

French and American Aërial Gunnery School at Cazaux. (Gironde.)

Use of machine gun. Courses for pilots and observers practically same. Three weeks.

First Artillery Aërial Observation School at Coetquidan. For training of observers. Course, two or three weeks.

Second Artillery Aërial Observation School at Souge.

For training observers. Course, two weeks.

Fourth Artillery Aërial Observation School at Meucon.

For training observers. Course, two weeks.

Fifth Artillery Aërial Observation School at Le Valdahon.

For training observers. Course, two weeks.

(All of the artillery aërial observation schools were used to train artillery personnel in the work of aërial observation.)

American Advance Artillery Observation School at Chatillon-sur-Seine.

Conducted in connection with second corps aëronautical school. Advance artillery and infantry liaison. Course, two weeks. 
74 The American Army in the European Conflict

American Observation School for Artillery Officers at Saumur.

Conducted in connection with artillery school. Length of course, three weeks.

French Elementary Flying School at Chateauroux. (Indre.)

Ninety students were instructed here in preliminary training by French instructors. Length of , course, two months.

Aërial Gunnery School at St. Jean des Monts.

Combination French and American school. Purpose, use and application of machine gun in the air. Length of course, about ten days.

FOR ORDNANCE

Ordnance School of Instruction at Is-sur-Tille.

Courses:

(a) Artillery material. Three weeks.

(b) Small arms and machine guns. Three weeks.

(c) Ordnance stores. Two weeks.

Ordnance Ammunition School at Jonchery.

Course: Composition, storage, and handling of artillery, trench mortar, and small arms ammunition. Length of course, eighteen days.

Ordnance Ammunition School at Foecy.

Purpose and course same as at Jonchery.

Ordnance School at St. Jean des Monts.

Purpose: Training in use and maintenance of automatic arms in connection with aërial armament 
work. Course varied from four to eight weeks, according to preliminary training of students.

Ordnance Experimental School at Langres.

Miscellaneous school.

FOR CHEMICAL WARFARE

Gas Defense School at Chaumont.

Course in gas defense. Length, six days. Capacity, 200 students. Usually for officers only.

FOR POLICE DUTIES

Military Police Corps Training Detachment at Autun.

Training personnel for military police units. Capacity, I, ooo. Length of course, two to three weeks.

\section{FOR TRAINING TRUCK DRIVERS}

Motor Transport School, Decize.

To train officers and soldiers in the operation and repair of motor vehicles. Capacity, I,500. Five separate courses, varying in length from two weeks for drivers to six weeks for mechanics and officers.

FOR INSTRUCTION IN CARE AND USE OF PIGEONS Pigeon School, at Saizerais, length of course, one week.

FOR INSTRUCTION IN MILITARY MUSIC

Bandmaster and Musicians' School at Chaumont, length of course, eight to twelve weeks. 
76 The American Army in the European Conflict

FOR INSTRUCTION OF OFFICERS AND SOLDIERS IN FRENCH SYSTEM OF HANDLING RAILROADS

Railway Transportation School at Angers (length of course, 2 weeks).

FOR INSTRUCTION OF CHAPLAINS REGARDING THEIR

DUTY WITH TROOPS

Chaplains' School at Le Mans.

A considerable time was necessary for the installation of all these schools on a running basis. While awaiting the opening of the above training centers, the Americans made a liberal use of our organizations, especially of our army schools, aviation, field artillery, heavy artillery, and railway artillery training centers.

We may add that the American army was also represented in the following inter-allied schools:

At Rosoy-en-Brie, where the practice of circulation or road traffic was taught.

At Fontainebleau, where training was given in tank maneuvers.

At $S t$. Dizier, where regulating officers were instructed.

This enumeration contains only the schools whose character was permanent and can give but an inadequate idea of the immensity of the task undertaken by the American command with a view to the necessary instruction of their rapidly increasing forces.

When General Pershing had elaborated his plans, chosen the personnel who were to carry them out, and those whom he placed at the head of the most important services, when he had selected the zones of both front 
and rear of his great army and decided upon the future theater of operations, he became impatient to group his staff in some locality nearer the battle-field where the chiefs of sections and the chiefs of divers active services might work in closer touch with one another.

He fixed his choice upon the town of Chaumont, situated not far from the end of his communication lines, in the very center of the various training camps and in close proximity to that portion of the front where his divisions were to take up certain trenches and where, according to all probability, the American troops under his command would strike their first blow.

The American headquarters were established at Chaumont during the first days of September, I9 I 7. Offices were installed in the barracks of the Iogth French infantry regiment; the officers were billeted in the dwellings of the citizens of this town. 


\section{CHAPTER III}

ESTABLISHMENT OF THE LINES OF COMMUNICATION ORGANIZATION OF THE SERVICES OF THE REAR

WhEN, on the first of February, I9I7, the directors of the German policy declared a merciless and unrestricted submarine warfare, they were confident that American intervention would be practically ineffective, and it must be confessed that, for a time, appearances were such as to give color to this theory.

The vast operations necessitated by the transportation to Europe of an American army - men, horses, munitions, and supplies - seemed, if Germany succeeded in barricading the European Atlantic ports with fleets of submarines, a perilous and almost impossible undertaking.

Moreover, although the immense stretch of American territory was rich in resources of all kinds, possessing railroads capable of tremendous activity, these resources and this activity had never been arranged with a view to military exploitation. The needs of a vast army in the field had never been foreseen.

No system corresponding to the various organizations created in France during peace time governing supply, requisition, and military purchase had been even thought of. The output of the arsenals was extremely limited, that of the factories turning out war material had not been centralized and was already, to a large extent, absorbed by the Allies. 
From the first day of mobilization, the railroads were seriously handicapped by the enlistment and embarkation to France of an important number of their personnel, and this was all the more serious when we consider that the great centers of production of the Middle West are linked to the ports on the Eastern coast by some twelve hundred miles of rail.

The crossing of the Atlantic - three thousand nautical miles - appeared extremely difficult to the naval experts and, at this time, the shortage in tonnage was acutely felt. During April the German submarines had beaten all previous records, having sent to the bottom 872,800 tons of allied and neutral shipping.

The French ports, many of which were already congested by the traffic of the British services, could not offer rapid debarkation facilities to numerous troops and immense quantities of supplies.

Although the French railroads were provided with trackage capable of supporting a greatly increased traffic, the rolling stock had greatly deteriorated, and the personnel was so depleted after thirty-two months of war that it would have been impracticable to subject these resources to a heavier strain than they were already enduring.

It was much the same in France for the resources of every kind which had been already so largely drained by the allied troops. What might happen if still another army were to add its demands to those of our own soldiers? Such were the anxieties, such the questions which had to be met and faced in order to establish the lines of communication, and organize the new services of the rear necessary to prepare for the entrance of the American forces on the scene. These brief remarks can give 
8o The American Army in the European Conflict

but an inadequate idea of the gigantic task involved, the immense difficulties that had to be conquered.

All the construction work, all the activities necessitated by America's entry into the war were to be developed in three entirely distinct sections.

The first of these, some twelve hundred miles in length, covered the distance between the principal centers of production and the American seaports.

The second, three thousand nautical miles in length, and including the Atlantic Ocean, was the scene of action of German submarine activities and was linked at either extremity by the American ports and those of the Allies.

The third, some five hundred miles in length, separated the French ports from the battle front in Lorraine.

Each of these sections must be separately dealt with, and as we desire more especially to dwell upon what we have ourselves observed, we shall give here but a summary of the work accomplished in America and on the ocean, in order to more fully describe the immense organizations realized upon the soil of France.

In peace time, the American army was administered by five distinct services.

The Quartermaster Corps supplied pay, food, forage, clothing, equipment, fuel, lodging, bedding, construction, and transportation.

The service of Ordnance supplied armament and munitions.

The Signal Corps manufactured or purchased aviation material, and all the apparatus for telegraph, telephone, and optical signalling.

The Engineer Corps and the Medical Corps furnished their own material. 
Between the sixth of April, I917, and the eleventh of November, 1918, in spite of the fact that absolutely no plan of mobilization had ever been matured in peace time the total strength of the army was to pass from 190,000 men to $3,665,000$.

These figures give a better idea than any description could do of the immense task entailed upon the separate services which were to deal with such large masses of material and men. Each service had to immediately reform and practically transform itself, increase effectives in an enormous proportion, enlarge their organization, and hastily improvise the training of a specialized personnel.

Thus the quartermaster corps developed between March, I9I7, and November, I9I8, to the extent of 220,ooo men: i.e., from 8,000 to 228 , 000 .

As to the methods employed by this service in dealing with a small army spread over an immense territory in comparatively petty detachments in peace time, they were unhesitatingly abandoned in the face of the new problems which had to be solved. The corps was completely reorganized into seven different divisions:

Clothing and equipage.

Forage and fuel.

Hardware and metals.

Remount.

Subsistence.

Vehicles and harness.

Motors.

In order to obtain a methodical exploitation of the country's sectional resources and to economize railway transportation, the whole territory was divided into zones 
generally marked so that each one should be able to supply the troops which were to be stationed in its territory.

Each zone was also to furnish its portion of supplies accumulated in the Atlantic seaports for shipment overseas.

Some idea may be formed of the size of these stores when it is considered that a permanent reserve of three months' supplies was to be constituted in France for the maintenance of the Expeditionary Forces.

At the same time, the quartermaster corps undertook the erection of large buildings destined to receive both troops and material of all kinds. The first project included the establishment of sixteen groups of barracks capable of containing 40,0o men each.

The difficulties encountered by the ordnance fully equaled those which were met and solved by the quartermaster corps.

The declaration of war found the American army with a system of manufactures which was scarcely adapted even to the needs of peace time.

Six hundred thousand Springfield rifles of the 1903 model were on hand and the daily output of this arsenal, joined to that of the establishment at Rock Island, did not exceed seven hundred pieces. The army had only a few hundred machine guns of various models (BenetMercier, Colt, Maxim, and Gatling), as none of these had been definitely adopted as a permanent standard for the American army.

The number of field guns did not exceed 780 pieces of small and I 4 of middle caliber. There existed no heavy field guns.

Neither the government arsenals nor the private manu- 
facturers were equipped so as to be able to produce the requisite number of guns of American pattern. As to the manufacture of shells, the factories capable of turning out any considerable amount were taken up with filling the orders of the Allied governments. However, fortunately and mainly on account of these orders, the United States was prepared for an appreciable development in the output of gunpowder and explosives, and strides had been made in the production of nitric acid by fixation of atmospheric nitrogen.

Thus, as we have seen, except for explosives the situation of the ordnance service had to be completely revolutionized. Radical measures were necessary and were immediately taken by the heads of this department.

In order to utilize those factories which had been producing the Enfield rifle, adopted by the British army, a type of weapon, called model I9I7, was developed resembling the English model but whose bore was modified in order to use the Springfield cartridge, which latter America was able to turn out in vast quantities.

Important orders were also given in France for Hotchkiss machine guns and Chauchat automatic rifles, at the same time experiments were made with the Browning light and heavy machine guns.

In June, 1917, it was decided to adopt French material for the American field artillery:

This decision greatly simplified matters, since it gave American factories time to transform and adapt their equipment, while the French industry, utilizing raw materials imported from the United States, should manufacture the first thousands of guns required by the American Expeditionary Forces. 


\section{The American Army in the European Conflict}

Some idea may be given of the development of the ordnance by the mere mention of the relative statistics of its operations for one year.

In June, 1917, this department transported 500 tons of manufactured goods and raw material. In June, I9I 8 , this total was increased to 100,000 tons.

When war was declared, American aviation was practically non-existent. The total strength of the service, including officers and men, did not exceed $\mathrm{I}, \mathrm{I} 85$. The number of machines was altogether insignificant. Experience gained on the Mexican border had proved that the types used were in no way adapted to the exigencies of modern warfare.

The aviation section of the signal corps had therefore to make a choice among the various existing models, if necessary to create new ones, and organize its manufacturing program from beginning to end.

In May, I917, the "Council of National Defense" created the "Aircraft Production Board," and a commission was sent to Europe in order to study the best types of war planes.

Experiments were undertaken with a view to creating a powerful engine which might be turned out in large numbers, according to the industrial methods of intensive production employed in America.

The Liberty engine was finally adopted; but, while waiting the first output of these machines in the United States, orders were given for great numbers of training planes of old pattern, the first of which were delivered in June.

In February, 1918, the first American made war plane with a Liberty engine arrived in France. 
The question of raw material presented immense diffculties.

Europe had largely depended upon America to furnish fir wood and spruce. Battalions of woodcutters were organized and set to work in the forests of the Pacific coast in which large quantities of those kinds of wood exist.

Shortage of flax made it necessary to find some substitute possessing the qualities required for a fabric used for covering airplane-wings. A manner of weaving cotton tissue was speedily found which proved entirely satisfactory.

Thanks to studies undertaken in the United States, a substitute was also found for castor oil as a high-grade lubricant, a mineral oil replacing the former was found equally satisfactory except for rotary engines.

The rest of the work of the signal corps, the construction and operation of telephone and telegraph systems, will be examined later, as will that of the engineer corps, ${ }^{1}$ in connection with the organization of the lines of communication on French territory.

But we must not leave the subject of the first measures of organization initiated in the United States without a short mention of the activities of the medical corps.

Figures must again speak for us rather than a lengthy description. From the beginning of the war to the armistice the medical corps in America established hospitals with a capacity for I 20,000 men and had under treatment I,400,000 patients, from August 30, I9 I 7, to August 30, I9I 8.

1 In the course of the war, the effectives of the engineer corps passed from 2,000 to 300,000 officers and men. 
The sick death rate among the troops stationed in America was only 0.64 per cent., a remarkably low percentage, considering that the army was composed of young recruits suddenly taken away from their homes and assembled in great numbers in hastily constructed camps and barracks.

The gas mask designed by this service was so efficient that no case is known of a soldier using it that died from gas poisoning.

In the space of seventeen months from June, I9I 7 to November, 19I8, the American army transported from one continent to the other 2,080,000 men and 5,160,000 tons of material.

Four-fifths of the men and half the material were shipped from New York, and a quarter of the material from Newport News, Virginia ; the remainder almost entirely left from Baltimore or Philadelphia.

The quartermaster corps and, after August 4th, the embarkation section of the General Staff, shared in the honor of having organized the system of sea transportation.

The first thing to be found was an adequate system of embarkation facilities. The docks of the Hamburg American line and the North German Lloyd at Hoboken, seized at the beginning of hostilities, were immediately utilized. But as time went on, they were found inadequate, and other docks, including those of the Lamport Holt Company, were added to the existing facilities.

Two camps were established in the immediate vicinity of New York, Camp Merritt and Camp Mills, each capable of containing 40,000 men. An enormous general storage depot was constructed at Port Newark, another for engineer material at Port Harrison, New Jersey. 
The large installations at Newport News were placed, like those of New York, under the command of a general. They included an organization camp for labor units and an embarkation center for animals.

Thanks to the highly developed railroad system of America and to the excellent equipment of the ports, huge masses of men and material could be transported without too much difficulty to the navigation companies' piers.

There remained the most difficult problem of all, on which we may say that the issue of the war in great part depended. Where could the ships be found that were to carry these men and this material?

According to what schedule and in what order of priority were the shipments to be carried out?

The German navigation companies who had supplied the piers might also be expected to supply the first necessary ships, and the government immediately laid hands on interned enemy shipping to the extent of 460 ,000 tons deadweight, chiefly consisting of passenger ships. But in consequence of willful destruction of the machines by their German crews and in some cases owing merely to a long stabilization in port most of these ships needed repair and could not be counted upon as serviceable before autumn.

It is also to be noted that even this large amount of tonnage represented little more than half of the allied and neutral shipping that had been sunk by enemy submarines during the month of April alone. Other measures of a drastic character had to be taken.

The entire output of the American shipping yards was requisitioned, orders were largely given by the government to private firms. All this entailed considerable delay. In order to meet immediate needs all available 
American merchant shipping was chartered; by the end of June the American army disposed in all of seven transports and six cargo boats, totalling 94,000 tons; at the date of the armistice that figure had grown to $3,800,000$ tons.

We shall examine elsewhere the methods employed during seventeen months to bring American tonnage up to the last-named figure. During the early period which at present occupies us, i. e., I9I7, the increase was rather slow, and in the course of the summer was almost entirely due to the chartering of American shipping.

After the month of September, the greater number of interned German ships became available. The following monthly table gives the increasing total of cargo tonnage assigned to the service of the American Expeditionary Forces in France.

June $\ldots \ldots \ldots \ldots$. 48,000 September $\ldots \ldots \ldots$ 223,000

July $\ldots \ldots \ldots \ldots$. 84,000 October ........ 291,000

August .......... 125,000 November ....... 460,000

December ........ 525,000

The army which left American shores was to be organized in France upon the arrival of its different elements.

Consequently one and the same section of the General Staff was at first entrusted with the plans governing organization and sea transportation.

The following self-evident considerations were now to govern the priority of shipments.

The exclusive transportation of combat troops would mean that the French services of the rear, already badly congested by the needs of the French army, would be still more strained by those of the American Expeditionary Forces. 
To ship troops unaccompanied by adequate supplies would mean that they would have to subsist on the resources of the country of their destination.

Three years of war had cut down the food supply of France to a degree that was on the verge of being perilous. The American command, well aware of the shortage existing in the month of April, 1917, was extremely anxious to supply the American troops by means of American resources in order to leave France in complete possession of her own and also with a view to minimizing as far as possible the unavoidable rise in prices consequent on the supplying of still another army. But, on the other hand, the shortage in tonnage made it absolutely imperative for the American command to find in Europe the greatest possible amount of supplies of all sorts. The importance of this may be fully realized when one knows that the transportation of one horse from America to France requires ten tons of shipping. It is easy to see therefore the immense economy of tonnage entailed if the A. E. F. could find in France or England or Spain a few thousand animals.

A close study of these difficulties led the high command to decide upon certain principles which, except in some unforeseen cases later mentioned, governed the execution of transport to Europe.

The Expeditionary Forces were to be embarked in successive phases or series, each sèries consisting of an army of some three hundred thousand men, equipped with all necessary auxiliaries. ${ }^{2}$

2 The following table gives in a condensed form the composition of the six first phases. Divisions, the number of which is followed by an $R$, are replacement divisions. Numbers followed by a $D$ are those of depot divisions. 
90 The American Army in the European Conflict

In each phase the auxiliaries and services were to be transported ahead of the combat troops.

\section{First Phase}

Service of the Rear................. 83,482

Army Troops R D ................... 7,200

First Corps (Divs. 1-2-26-32-41-42....... 174,1 18

Army Troops $\ldots \ldots \ldots \ldots \ldots \ldots \ldots \ldots \ldots \ldots \ldots \ldots$

Total First Phase.................. 275,200

\section{Second Phase}

Service of the Rear R R.

Second 'Corps (Divs. 28-30-77-78-80-82) ...... 178,114

Army Troops $\ldots \ldots \ldots \ldots \ldots \ldots \ldots \ldots \ldots \ldots \ldots \ldots \ldots \ldots \ldots, 16,262$

Total Second Phase................... 267,490

Total to date...................... 542,690

Third Phase

Service of the Rear RR.............. 52,124

Third Corps (Divs. 3-4-5-6-33-35) ........

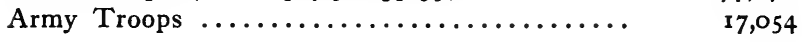

Total Third Phase................... 246,248

Total to date..................... $\quad 788,938$

Fourth Phase

Service of the Rear................. 40,95

Fourth Corps $\ldots \ldots \ldots \ldots \ldots \ldots \ldots \ldots \ldots \ldots . \quad \mathbf{1 7 7 , 0 7 0}$

Army Troops $\ldots \ldots \ldots \ldots \ldots \ldots \ldots \ldots \ldots \ldots \ldots \ldots, \quad 13,722$

Total Fourth Phase................... 231,743

Total to date...................... $1,020,681$

Fifth Phase

Service of the Rear.....................

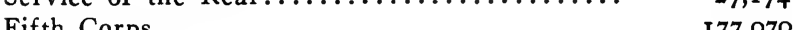

Army Troops

Total Fifth Phase..................... 2 10, 100

Total to date..................... $\quad \mathbf{1 , 2 3 0 , 7 8 \mathbf { I }}$

Sixth Phase

Service of the Rear....................

Grand Total (excluding Aviation and replacements)

I6,6 I 8 
One month of supplies was to be sent with each convoy. A reserve of three months' supplies was to be permanently maintained in France for the total effectives landed; forty-five days' rations were to be kept in the vicinity of the ports, thirty days in the interior of the country, fifteen days at the front.

Thus, the shipment of supplies would proceed automatically, and without any special application being made to Washington.

On these principles, General Pershing's staff established a document of paramount importance, the "Priority Schedule," which was sent to the War Department and determined the order in which different organizations, personal and material, were to be sent to Europe.

Military events naturally greatly modified this scheme. And the early sending of a division of infantry decided on moral grounds, was the first of a series of modifications that had to be made to the original priority schedule.

This division of the regular army left America in several detachments. A convoy including fifteen ships and carrying 15,000 men and 16,000 tons of material and supplies set sail between June I 2 th and I 7 th for St. Nazaire, arriving on the morning of June 26 th. The voyage, thanks to the extreme vigilance of the United States Navy, took place without loss.

Admiral Sims had come to London during the early days of April in order to organize the protection of American ships in European waters. It was decided, after a very careful study had been made of the matter, that each convoy when six hundred miles from our coasts should be taken in charge and escorted by a flotilla of destroyers.

In order, also, to evade an attack which might take 


\section{The American Army in the European Conflict}

place in mid-ocean if a fast German cruiser succeeded in running the coast blockade, each convoy was accompanied from America by an armored-cruiser. The Seattle was the first of these to arrive with a convoy in European waters.

The American navy accomplished during the period of hostilities a task of which we can here but mention the result.

Out of more than five million tons of material sent from America to France only 79,000 tons were lost at sea. The total amount of American shipping sunk was 200,000 tons, I42,000 of which was due to submarine attacks.

We have thus rapidly sketched some of the measures taken in view of assembling in America and transporting across the ocean the vast masses of men and material of the Expeditionary Forces. We shall now in turn examine the gigantic organization undertaken on French soil, which permitted their reception on arrival and allowed of their rapid forwarding at an ever increasing speed, to the battle-fields where the fate of the great war was being decided.

The organization of the lines of communication and of the services of the rear of the American army was carried out in France, as had been the case in America and on the Atlantic, by a body of practical men, anxious to make the best of existing circumstances at the time of their arrival, to do things on a large scale, and to do them quickly.

When news of the declaration of war reached Paris, Major Logan, head of the American military mission in France, and Captain Boyd, the United States military at- 
taché, at once made every effort to gather all information which might make it possible for the government at Washington in the first place, and for the commander of the Expeditionary Forces in the second, to arrange, with full knowledge of prevailing conditions, the bases of their future organization.

At this moment, both officers were entirely uninformed as to what character American intervention would take. And, in regard to the future activities of the great republic, the most varied and contradictory rumors were circulated.

Would America merely content herself with supplying the Allies with war material of various kinds? Would she send over detachments of volunteers or aviation troops? Would great armies be enrolled for combat on European soil? To none of these questions were the American military representatives in Paris furnished with an answer. The government of the United States had not made known any decision in these matters; possibly they were waiting, on their side, for the result of the inquiries which the American military mission was to make in France.

If in modern warfare the services of the rear are necessarily obliged to adapt their mobile organizations to strategical exigencies, strategy, on the other hand, must also take into consideration certain prevailing conditions. Most particularly, it was advisable that the American army should profit, in so far as possible, by certain permanent facilities and organizations existing on French territory at the time of its arrival.

We have already observed to what great extent such material considerations shared in the decisions of the French and American supreme command when they de- 


\section{The American Army in the European Conflict}

cided as to the future zone of action of the Expeditionary Forces.

The military mission had the task in hand of determining upon the selection of the most favorable ports for the debarkation of vast numbers of troops; they had also to decide how to supply these troops and where to assemble them upon arrival.

During April and May, the American mission verified on the spot the information received from the French General Staff in regard to these questions and, accompanied by several French officers, among whom one of the writers, made an extensive tour of ports, railroad yards, hospitals, and storage depots of all kinds. Major Logan and his associates thus got precise details on the resources at our command and the part which they might claim in their use. Often the field of study and selection was extremely limited; this was especially the case in regard to our seaports.

Those giving upon the Channel, as far as Cherbourg, inclusive, were being utilized up to their full capacity by the services of the British army and those of the French. Brest, which had never been utilized except as a naval base, had never been equipped with the facilities for handling a heavy traffic. Neither did this port possess any basins provided with locks, so that the debarkation of men and freight could only be carried out by lightering.

At St. Nazaire the conditions appeared more favorable. The port was accessible at all times to ships drawing twenty-eight feet; it was supplied with two large basins and, providing that certain measures were taken, was capable of a daily output of several thousand tons.

At the time of the first German advance toward Paris in I9I4 the town had served as a base for the British 
armies and 25,000 men had simultaneously been quartered in the extensive camps situated upon the neighboring heights.

Furthermore, there existed at St. Nazaire a remount depot which was very well organized and could contain 3,0oo animals.

Unfortunately this port had several serious drawbacks. The piers were narrow, the warehouses few and far from capacious. The vicinity of habitations made it impossible to build new ones. The railroad lines on the piers were in poor condition, drinking water was scanty, and the port itself was very much congested.

Nevertheless it was hoped that by developing the water-works undertaken by the British in I914 it would be possible to furnish the camps with water in sufficient quantity, and at the extremity of the Penhoet docks, close to Montoir, there existed extensive stretches of flat ground which would be excellently adapted to storage purposes. The French had already begun at this point the construction of a few warehouses. With adequate labor and rolling stock it seemed possible to repair the tracks on the piers and relieve the congestion of the port.

We should also note that Nantes, situated at some forty miles from St. Nazaire, could dispose of three or four berths with twenty-five feet of water and correspond. ing warehouses.

In the harbor of La Palice, the Americans could at once utilize two berths and a forty-ton crane.

In the Gironde region, Pauillac possessed a long and narrow wooden pier only linked with the main railroad system by a single-track line.

In order to utilize this, it was necessary to cross the 


\section{The American Army in the European Conflict}

Gironde on the only railroad bridge which exists at Bordeaux and consequently add to the congestion already considerable at this point.

The port of Bordeaux itself, situated on the left bank of the Gironde, a fact which, from the railroad point of view, presented the drawback mentioned for Pauillac, was already working at its maximum capacity.

On the other hand, at Bassens on the right side of the river and five miles downstream from Bordeaux, the French had begun, in 1915 , the construction of piers for the traffic of the important powder factory situated at this point. In April, I9 I 7 , the third berth was nearing completion and the possibilities of extension were, so to speak, unlimited.

Furthermore, between Bassens and St. Suplice, in the vicinity of the main line to Paris, stretched vast ground favorable for the establishment of extensive camps and storage. It was evident that if the Americans were to have a base in the Gironde, Bassens was specially indicated as its center. Such was, generally speaking, the situation of the Atlantic ports.

As to the Mediterranean ports they were not then to be thought of. The advisability to avoid an increase in the duration of the round trips, the intensity of submarine warfare, the necessity of not dispersing the ships then available for escort duty, all pointed to the advisability of concentrating efforts on the Atlantic bases.

Accordingly, it became evident that if America were ever to send a large army to fight in France the first base would be upon the Loire estuary, with St. Nazaire as main port, the second on the Gironde with its main port at Bassens.

Thus the starting point of the lines of communication 
upon French territory were practically imposed by circumstances and, their point of arrival having been decided upon by General Pershing as necessarily in the region of Lorraine, it only remained to select railway lines which were to link the American base ports with the combat zone and also to decide upon the location of the facilities which were to be established along those railway lines or in their immediate vicinity.

The structure of the French railroad system was well fitted to the establishment of such a line of communication running from the southwest to the northeast, traversing the whole breadth of the country from the mouth of the Loire and the Gironde to the upper valleys of the Marne, the Meuse, and the Moselle.

The main line, running through Nantes, Tours, Bourges Nevers, Chagny, Dijon, and Is sur Tille ( 446 miles) was at too great a distance from the front to serve for the transversal movements of the French troops and was comparatively uncongested.

The stream of traffic coming from Bordeaux could be branched on to this main artery either at Tours via Poitiers or at Vierzon or Bourges via LimogesChateauroux.

A number of more or less large towns situated on these main railway lines offered important facilities already existing, as well as buildings that might receive new organizations, the whole or part of which could be turned over to the American services of the rear.

In those cases where it was necessary to erect new constructions at different points of the road, considerable acreage of flat ground existed in close proximity to the line.

Such in a general way was the sort of practical informa- 
tion collected for General Pershing, and which was laid at once before him upon his arrival in Europe.

As he reported himself to the Secretary of War:

“... All these considerations led to the inevitable conclusion that if we were to handle and supply the great forces deemed essential to win the war, we must utilize the southern ports of France - Bordeaux, La Palice, St. Nazaire, and Brest - and the comparatively unused railway systems leading therefrom to the northeast. Generally speaking then, this would contemplate the use of our forces, against the enemy somewhere in that direction, but the great depots of supply must be centrally located, preferably in the area included by Tours, Bourges, and Chateauroux, so that our armies could be supplied with equal facility wherever they might be serving on the western front."

Thus as we have seen the general organization of the rear of the American armies was rather a question of circumstance than of planning and the conclusions arrived at, as General Pershing aptly expressed it, were inevitable in the spring of 1917.

In order to realize these projects the Americans were called upon for the greatest exposition of energy, acumen, and perseverance in their decisions, when once adopted.

They went to work with a view of perfecting what already existed rather than to create entirely new facilities. Thus, upon the signing of the armistice, the number of berths utilized by the American shipping in French ports, amounted to $98 ; 85$ were of French construction and 12 only had been built entirely by the Americans.

Although the output of our ports was small in I9I7, they nevertheless did exist with their piers, their docks, and their locks usually in good condition. It was sufficient to prevent congestion - herein the American effort 
was particularly efficacious - to equip them after more modern methods and to provide them with facilities for unloading and storage, with labor and rolling stock.

One of the first duties of the commission of specialists sent to France in the month of June (among whom was Major Wilgus, ex-vice-president of the New York Central), was to improve conditions of the port of St. Nazaire.

The United States Government was requested to send over a quantity of labor units and a large number of hoisting machines from seven to twelve tons. It was also decided, in order to meet the then very great difficulties in transportation facilities, to create a large storage depot in the vicinity of Montoir some four miles northeast of St. Nazaire, which was destined to receive the supplies until it was possible to transport them nearer to the front. ${ }^{3}$ The plan included a large number of warehouses provided with a system of receiving, classification, and departure yards branched at one end on the tracks of the port of St. Nazaire, on the other end on the main line: St. Nazaire - Nantes.

The entire length of railway lines to be constructed was 250 miles; the total capacity of the warehouses was to be over $14,000,000$ cubic feet.

In case the port of St. Nazaire should be found inadequate, a plan of docks was designed to be constructed on the Loire near Montoir. This was to include eight berths with a constant draught of thirty feet.

The shipbuilding yards at Penhouet, with their cranes of one hundred and fifty and one hundred and eighty tons, were admirably fitted for the debarkation of heavy loads,

${ }^{3}$ Montoir was also to serve as a permanent general storage depot for Base Section No. I. 


\section{I00 The American Army in the European Conflict}

and several workshops for mounting locomotives and railroad artillery were established there. ${ }^{4}$

The Igth American regiment of engineers, consisting exclusively of skilled personnel, was to be utilized not only for the erection of the locomotives sent from the United States but also was expected to repair the French and Belgian locomotives.

At St. Nazaire there was also established a shop where the automobile vehicles which had been sent in parts to economize tonnage were assembled.

Nine camps with a total capacity of 40,000 men were established for the reception of passing troops as well as for those permanently assigned to the base.

A filtering plant with apparatus for a daily flow of 7,500,000 gallons was speedily established.

At Savenay, also, large watertanks were constructed, with a capacity of $100,000,000$ gallons in order to supply two hospitals each of 2,500 beds. This water was obtained from a small river at a certain distance from the town.

Finally at Nantes the depots of St. Luce were constructed and it was decided to double the Orleans railway line along the portion of the road where it was single-tracked; that is to say, from the Pont de la Rontonde to the Bourse.

Thus equipped, the lower Loire became the American Base No. I.

From the month of August, work was in progress on American Base No. 2, which was being prepared at Bassens.

There, as we have seen, the French service of public roads and bridges had been constructing docks on the

4 The boiler of an American locomotive weighs twenty-three tons. 
right bank of the Gironde; their plan included ten berths, and in May the third of these was approaching completion.

The French services agreed to turn over these docks to the Americans during the lapse of time necessary for the latter to construct new ones. On the other hand the Americans offered to share in the work which we had undertaken and agreed to construct ten new berths downstream from the powder mill.

The installation of the port of Bassens was thus to include two quite distinct series of docks, each of which could handle ten ships:

The French port of old Bassens partly of French, partly of American construction.

The American port of New Bassens exclusively of American construction.

The plans designed by Major Wilgus for the railroad system of the American Bassens was a model of perfection and simplicity.

The tracks formed a loop where circulation was always in the same direction. The cars arriving by the main line, Paris-Bordeaux, were at first sent to the receiving yards, whence, according to requirements, they were sent to the tracks established on the piers and alongside the warehouses, where they were loaded. Finally they continued to the classification and departure yards and from there, toward St. Sulpice or more remote destinations.

The facilities at Bassens were also to include a refrigerating plant. The frozen meat being unloaded from the holds of the ships was to be subject to a second refrigeration, which would be sufficient to allow it to be forwarded to Gièvres in ordinary box-cars. It was thus possible to do without refrigerator cars. 


\section{IO2 The American Army in the European Conflict}

Just as the Montoir general storage had been established in order to absorb the overflow from the port of St. Nazaire, it was decided to construct at St. Sulpice on the Paris line an immense depot for the reception and storage of supplies which were unloaded at Bassens. Port and storage were to be linked by an independent railway established alongside the main line.

Besides Bassens the other facilities contiguous to the Bordeaux base were to include camps for troops, a hospital center at Beau Desert containing 25,000 beds, depots for ordnance and quartermaster material respectively at St. Loubés, La Bastide, and Lormont, remount depots at Lormont and Merignac.

On the whole it may be said that the two American bases in France were established on the same principles.

In each were to be found, first a port of debarkation equipped along modern lines; second and next to the port to which was linked by an independent railroad line a general storage depot; Montoir for St. Nazaire, St. Sulpice for Bassens.

The depot has a double rôle; it should not only absorb the output of the port no matter what its volume might be, in order to avoid congestion, but also it should constitute for the intermediate zone a reserve from which supplies might be drawn according to requirements.

Various organizations necessarily grouped themselves about this nucleus: camps, hospitals, bakeries, remount stations, workshops, assemblage and repair plants.

It may be interesting to note here that the two great bases - St. Nazaire-Nantes and Bordeaux-Bassens - in the course of the war unloaded almost two-thirds of all the freight imported for the use of the American Expeditionary Forces, to be exact, 62.03 per cent. 
These installations which were established in the other French ports, such as La Palice, Brest, Le Havre, Rochefort, and Marseilles, were not nearly so important and will be spoken of later.

The transport difficulties were not by any means over when the personnel, animals, supplies, and material were landed and grouped in the various camps, remount stations, and depots in the vicinity of the base ports - in fact they were only begun. Other problems remained; that of forwarding these masses of men and material to the front, and that of providing for their maintenance and adding to their numbers by drawing upon the local resources of the country. The following figures will indicate that such resources were by no means negligible.

Out of the 243,560 animals of which the Expeditionary Forces disposed during the war, 67,725 only, were imported from America. And here, at the risk of anticipating events, it seems indispensable for us to sketch some of the general prescriptions addressed to the services of the rear in view of their individual organization and in order to assure the coördination of their activities. In General Order No. 8 (dated July 5, I9I7) the commander-in-chief already determined the precise duties of the organization which, seventeen months later, was to handle millions of men and distribute millions of tons of supplies and material.

By the terms of this document, the chief of the line of communications was entrusted with the territorial command in the whole zone of communications with the supply, sanitary, telegraph, and telephone service and all construction work.

On August I 3 th General Order No. 20 created practically all services of the rear in France. The geograph- 


\section{I04 The American Army in the European Conflict}

ical limits of the line of communication extended from the seaports to the railheads which served as base of supplies for the field transportation of the combat troops.

It included three separate zones which were denominated as follows:

The Base Sections: The three first were created at St. Nazaire, Bordeaux, Le Havre (this latter base section being the agency for receiving and dispatching troops and supplies arriving in France at Channel ports via Great Britain).

The Intermediate Section: Whose limits were comprised between those of the advance section and those of the "base sections."

The Advance Section: Formed by the French zone of the armies.

The line of communication was charged with the service of military railways including operation, maintenance, and construction.

To begin with, the following lines of railroad were to be considered as military railways belonging to the line of communications, for the purpose of railway movements of troops and material and the use of existing facilities under French control.

Saint Nazaire-Tours-Bourges-Dijon-Is-sur-Tille and points to the front.

Bordeaux-Limoges-Bourges.

Regulating station: Is-sur-Tille.

The postal service and military police were also to form part of the line of communication. Brigadier-General R. M. Blatchford was appointed commanding general, line of communication.

And here we must mention two other orders of the 
commander-in-chief on account of the great importance of the new services which they organized: General Order No. 23 of August 2oth established in Paris a general purchasing board with a general purchasing agent at its head. The general purchasing agent was to be the representative of the commander-in-chief with the various allied purchasing agencies; his duties were to coördinate and supervise all purchasing agents of the American Expeditionary Forces.

General Order No. 37 of September I4th, established at headquarters a transportation department in charge of the operation, maintenance, and construction of all railroads and canals under American control, together with all constructive work to be undertaken on wharves, shops, and other buildings for railroad purposes.

The chief of the transportation department was the director-general of transportation and was assisted by the following staff:

(a) Deputy director, $(b)$ engineer of construction, (c) manager of light railways, $(d)$ manager of roads, $(e)$ business manager, $(f)$ general manager, $(g)$ deputy director with each army commander.

General Atterbury, ex-vice-president of the Pennsylvania Railroad, was appointed D. G. T.

Colonel Wilgus was appointed deputy director.

Thus during the summer of 1917 , under vigorous impulsion of American Headquarters, the general organization of the services of the rear was making speedy progress. The organization was, however, still far from having the character of unity and centralization which it acquired later on.

At the end of 1917 the supply of American troops in France was divided into three phases: 
The procurement of supplies, their care and storage, their transportation.

Responsibility for the first, lay with the chiefs of various supply departments (quartermaster, engineer, ordnance, etc). It was accomplished by purchase or requisition in the United States or in Europe.

The second was placed under the control of the general commanding the lines of communications, who was responsible for the care and storage of supplies, material, and equipment, and for the construction, maintenance, and repair of all agencies necessary to accomplish this purpose.

The third fell to the director-general of transportation, who had charge of the unloading of freight and troops from ships at the points of debarkation, of the transportation of all troops and supplies by rail, and was responsible for the construction, maintenance, and operation of such railroad lines and rolling stock as came within American control.

And now, following the American line of communication in France we will leave the zones of the bases in order to penetrate with our reader into the intermediate section before reaching that of the advance.

This intermediate section would have had no reason to exist if the front of I9I 7 was to be stabilized or if, between this front and the base ports, it had been possible to count upon an absolutely regular working of the railways. In that case, nothing would have prevented the storage of supplies either in the zone of the advance or in the vicinity of the base ports.

In practice it was quite otherwise.

On the one hand, to accumulate vast stores in the army 
zone would have been (without mentioning the constantly increasing dangers of aërial bombardment) running the risk of seeing these supplies fall into the enemy's hands in case of an even slight advance on his part, as occurred at the end of November after the battle of Caporetto, when the Italians lost vast quantities of supplies stored in close proximity to the front.

On the other hand, if these stores were left in the immediate vicinity of the ports, and were only drawn from according to need, it would have meant the necessary risks and delays involved in war time in a continuous railroad transportation on a distance of five hundred miles.

Consequently General Pershing decided, between the zone of the bases and that of the advance, to create a third one - the intermediate section, intended to play the rôle of a regulator for the shipments from the first and the requests made by the second.

Moreover this intermediate section, covering as it did a stretch of the country where the armies had not been quartered, made it possible for the American services stationed on its territory to procure by calling upon local resources certain supplies which it would have been impossible to obtain nearer the front.

It was evident that the different services of the rear should have their large installations in the vicinity of the main embarkation lines which, starting from Bordeaux and from St. Nazaire, utilized the same tracks from Bourges to Is-sur-Tille.

The quartermaster corns decided to establish remount depots at Selles-sur-Cher, Gièvres, and Sougy; automobile acceptance and repair parks at Tour, Chateauroux, and Nevers; refrigerating and cold-storage plants at Tours, Gièvres, Blois and Orleans, bakeries at Dijon and Giè- 
vres. At Tours there was organized a plant for the repair and salvage of clothes and equipment of all sorts, making possible immense economies of both money and tonnage. Motor service and overhaul parks were established at Paris, Tours, Romorantin, and Nevers.

The principal depots and repair shops of the ordnance were installed at Mehun, Fœcy, Gièvres, Romorantin.

The medical corps established hospitals in all the above localities and, besides, created important hospital centers in the region of the thermal stations of Auvergne (Le Mont'Dore, La Bourboule, Royat, and Chatel-Guyon).

As to the engineers corps, charged with the construction work (railroads, camps, barracks, hospitals, depots of all sorts) its activities extended over all the region where American soldiers were stationed. Its main depots were located at Chateauroux and Gièvres.

The signal corps began the construction of independent telephone and telegraph lines destined to connect the headquarters at Chaumont with Paris, Brest, St. Nazaire, and Bordeaux.

The aviation section established a plan for a large production center at Romorantin.

Of all these installations in the intermediate section, of all those that have been established by any army at any time and at any place in the course of the war, the most important from every point of view was the general intermediate storage depot at Gièvres. Constructed upon flat ground, adjacent to the railway line, Tours-Bourges, and fifty miles distant from Tours, it was destined to be the general storage depot of the intermediate section for engineers, medical, quartermaster, ordnance, and gas supplies.

The depot itself, not counting the barracks and hos- 
pitals annexed, consisted of a large number of warehouses, vast surfaces of open storage, a refrigerating plant, and the corresponding railroad yards. The definitive project included 243 miles of rail, of which I 55 miles were standard gauge road, 4,492,000 square feet of storage space; as for the refrigerating plant, it had a capacity of 5,200 tons.

Gièvres, on account of its importance and geographical situation, naturally became the main storage depot which, according to the words in General Pershing's report to the Secretary of War, permitted the American armies to be supplied with equal facility wherever they might be serving on the western front.

During the early days of the organization of the services of the rear, the line of demarcation between the intermediate section and that of the advance was less definite than in the French system.

As we have seen, the authority of the general commanding the line of communications extended from the ocean ports to the points where supplies were delivered to the field transportation of the combatant field forces.

The general commanding the advance section, of which Neufchateau was the headquarters, found himself charged with the establishment, construction, and operation of all the camps, hospitals, remount depots, storages of all kinds situated in the French "Zone of the Armies" and placed under American control. He procured the necessary supplies either by means of local purchases or by requisitions on the rear and was in charge of their storage in the advance depots.

According to the terms of the general order of August

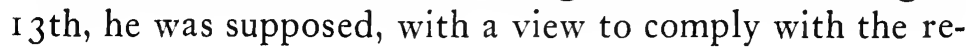




\section{Io The American Army in the European Conflict}

quests of the fighting troops, to draw from the advanced depots the necessary amount of supplies, and forward them to the railheads; i. e., to the filling-up points of the "field transportation of the combat field forces."

This simple system had the advantage of centralizing the responsibility to the utmost, and it sufficed for a long period during which the American troops were occupying the same billets and the same quiet sectors upon the Lorraine front, but it was no longer sufficient for their needs when the large units were definitely formed and engaged in active operations. This sort of operation necessarily entails a very heavy transportation of men and material, a traffic of reënforcements, evacuations, and supplies in the course of which any undue delay may spell disaster.

It is therefore essential that the army whose interests are involved should be able to present its demands, without intermediary, to an authority who has full powers and means to meet them.

In the French organization this rôle is filled by the regulating station to which the armies in the field ask directly for the transport of all kinds which they may require.

After close study of the question General Pershing decided to adopt an analogous system for his armies.

On December I 2 th, a general order prescribed that the troops in the zone of the armies should be supplied from the storage depots by means of regulating stations. The regulating officer - i. e., the officer in charge of the regulating station - was no longer under the orders of the general commanding the lines of communication, but was a member of the coördination section of the General Staff of the army or group of armies, supplied through his regulating station.

$\mathrm{He}$ drew the supplies from the depots of the lines of 
communication, forwarded them to the refilling points (railheads), where they were turned over to the field transportation of the troops. Usually a separate train was provided for each division.

The details of the formation, forwarding, and running of trains were arranged under his supervision and, according to his instructions, by a representative of the transportation department; in short the Americans practically reproduced the French system and, as in our case, arranged that the military authority should work side by side with the seasoned railroad man.

Moreover, the position of the American army, which at the beginning was called upon to act in close contact with the French armies, made it desirable, in so far as possible, to adopt a similar organization.

The first American regulating station was established at Is-sur-Tille, far enough from the front to make it possible to add to the station an important advance general storage depot, including a bakery with a daily output of 300 tons of bread.

The construction work carried out at Is-sur-Tille, which was entirely completed at the time of the armistice, is one of the most important undertaken in France by the American engineers: The total length of tracks in the yards amounted to ninety-six miles (normal gauge).

At almost the same moment, the American services decided to build a second regulating station at Liffol-leGrand near Neufchateau, located nearer the front and destined to ultimately replace Is-sur-Tille which would, by that time, have become the general storage depots of the advance section, as Gièvres was that of the intermediate section.

The construction of Liffol had been decided with the 


\section{2 The American Army in the European Conflict}

French general headquarters, in the course of numerous conferences between Colonel Payot, director of the French service of the rear, and Colonel W. D. Connor, chief of the coördination section at American headquarters.

It was understood that all the large installations of the zone of the armies were to be interchangeable and might be used by any of the Allied armies, according to the turn which events might take.

Thus each, while working ostensibly for his own army, was in reality working for every one.

Naturally, the first installations of the advance section were established along the lines leading to the Lorraine front: general storage depots at Chaumont, Vittel, Bazoilles, Liffol; motor transport parks at Vesoul, Epinal, Neufchateau, Gondrécourt, Toul; ordnance depot at Villers-le-sec; bakeries at Chaumont, Rimaucourt, Neufchateau, Vittel; refrigerating plants at Is-sur-Tille, Chatillon, Epinal; remount depots at La Neuville, Bourbonne, Montiers-sur-Saulx, Nancy; forestry centers at Epinal, La Marche, Domgermain; hospitals at Chaumont, Neufchateau, Contrexeville, Vittel, and Toul.

From the first days of the war, the American Government fully realized the immense importance which a good organization of railroad transportation would have for the Expeditionary Forces; consequently it had at once sent to France a commission of experts constituted by some of America's most competent railroad men.

The principal members were Mr. William Barclay Parsons, who had built the first New York subway; Mr. W. F. Wilgus, ex-vice-president of the New York Central, and Mr. W. A. Garrett. 
This commission found the railroad system of France in surprisingly good condition, but suffering from a shortage of rolling stock and labor that enormously reduced its transportation capacity; its first care was therefore to appeal to the resources of the United States.

General Pershing, informed of the situation, at once requested Washington to send over to France a man perfectly qualified by his experience to assume the general direction of railroad transportation, and in August, $\mathrm{Mr}$. W. Atterbury, vice-president and general manager of the Pennsylvania Railroad, arrived in Paris and at once set to work with Major Wilgus.

Their general plan was to organize the transportation of the American Army in France along the same lines as a great railroad company and including all its usual branches; the only difference was that no anxiety existed as to the financial returns of the operation of the system.

Let it be mentioned incidentally that, contrary to the legend which was currently circulated by the public and even in the newspapers, the Americans did not have to construct in France any important railroad line whatever. Practically only terminal and storage tracks were built by them. The only double main line constructed was five miles in length. It was established as a cut-off connecting the main line of the P. L. M. Railroad south of Nevers, branching off near Challuy, crossing the Loire River, and rejoining the main line near St. Eloi.

Other important projects included the addition of a third track on the Bassens-St. Suplice line, connecting the lines of the Orleans and state railroads at Nantes, and the laying of two additional tracks between Bourges and Pont Vert.

In order to face the shortage of rolling stock, two 


\section{4 The American Army in the European Conflict}

solutions presented themselves to General Atterbury: the first was importation from America, the other consisted in repairing, by means of American labor, the thousands of damaged French and Belgian locomotives and cars which were lying idle as a consequence of the lack of skilled workmen.

In December, 19 17, both solutions were simultaneously taken up.

The main repair shops were established at Nevers, Cercy-la-Tour, and Saumur.

Rejgiments of American engineers were placed at the disposition of the transportation department. These were of three categories:

Ist. Construction Regiments.

2d. Operation Regiments.

3d. Shop Regiments.

They were made up strictly of specialists in the different branches, officered by men who were, for the most part, civil engineers of great experience. Thus the class of work might be expected to be very high.

We shall see later the process of transformation which was effected in this organization of which the bases were laid as early as the summer of I9I7; but before leaving the subject of transportation, we must say a few words on that of the motor transport service which, during the war, was to bring such effective and ever-increasing aid to the overstrained railroads and attain greater and greater importance. The motor transport service was organized in each of the three sections of the line of communications by a general order dated December 8th.

It included in the advance zone one park per army, in the intermediate section an intermediate group consisting 
of several organizations, among which was found a central depot comprising the following sections: Supply, spare parts, main shops, salvage, main reserve park, and finally in the base zone a park established in the vicinity of each port of debarkation. This park was to receive all incoming motor transport vehicles and personnel, to organize the units, and afterward forward them to the organizations of the intermediate section, or, in case of emergency, directly to those of the advance section.

Thus the reader who has patiently followed these long explanations may be able to form some idea of the American services of the rear as they were established in France at the end of 19 I 7 . 


\section{CHAPTER IV}

FIRST APPEARANCE OF AMERICAN CONTINGENTS ON THE FRENCH FRONT - THE FIRST, SECOND, TWENTYSIXTH, AND FORTY-SECOND DIVISIONS

DURING the conversations which took place between Marshal Joffre, the American Secretary of War, and the President of the United States, touching the forthcoming intervention of America in the European conflict, the marshal had dwelt upon the necessity of forming a large number of strong war units and also upon the urgency of the appearance of a first American contingent on French soil. It was considered that the early arrival of American soldiers among our troops at the front would produce an extremely salutary moral effect. His suggestions were favorably received.

Great diligence was displayed in the different offices of the War Department, and various units were rapidly grouped together to form one division. The 16 th, I 8 th, 26 th, and 28 th regiments of the regular army, which were then for the most part engaged upon the Mexican border, were incorporated into the First Division.

This division, which was the first to respond to the call of the victor of the Marne, and to display the Stars and Stripes beside the tricolor, arrived in France on the twenty-sixth of June and disembarked under the eyes of General Pershing.

The soldiers who composed it, volunteers as well as I 16 


\section{First Division}

regulars, produced an excellent impression; we quote the remarks of a French spectator:

"Orders are promptly executed, maneuvers are effected with skill, every one knows his place and his business. The operations of disembarking, gathering the small units, and marching to the barracks are carried out with discipline and order. The men are well set up, and seem perfectly at ease upon French soil; with their khaki uniforms closer cut than those of the English, with their picturesque sombreros, and their eminently practical equipment they give the impression of cohesion. The soldiers appear to be strong, athletic, and healthy, and one has the feeling that the nerves of such a troop will act with force and precision at the hour of combat."

General Sibert, an officer of engineers, who had been one of the most efficient among those who constructed the Panama Canal, was in command of the First Division. The two brigades were respectively under the orders of Generals Bundy and Bullard.

Upon arriving, the troops at once took possession of a camp situated in close proximity to the port of St. Nazaire, and which had been prepared to receive them while awaiting the time when their cantonments would be moved nearer the front.

Their sojourn, in fact, was not a lengthy one; on the fifteenth of July the division was entrained for the Gondrécourt area before going into the trenches for the first time.

Meanwhile the Fourth of July, one battalion belonging to the Sixteenth Infantry carrying the flag of the regiment arrived in Paris, marched in defile before the President of the Republic, and received in the Court of Honor at the Invalides, the standards offered by the French Sons of the Cincinnati. Thence, traversing the 


\section{8 The American Army in the European Conflict}

capital, amidst the acclamations of the Parisians, the first American soldiers who were to take up arms for their "second country" escorted the American Ambassador and General Pershing to the tomb of the friend of Washington and gave utterance to the now historic, "Lafayette, nous voilà."

When the Sibert division took possession of their instruction camp they occupied a line of villages stretching along the Saulx from Gondrécourt to Ligny-en-Barrois.

Here, for the first time and contrary to custom, the American soldier did not pitch a tent, but was lodged after the French manner; that is to say, in the villages and adjacent farmhouses. He soon made himself quite at home in the barns of our peasantry.

Each battalion disposed of its own drill ground, rifle range, trench system, and wire entanglements. Divers centers for the handling of grenades and other weapons were established at Mauvages while awaiting the installation of army corps schools. Officers and men were to pass fifteen days at these training centers and, on returning to camp, were to act as instructors.

The French Forty-seventh Division of "Chasseurs à pieds" was now placed beside General Sibert's division to serve as a sort of guide in these maneuvers. Every day lines of French and Americans were to be seen digging trenches, practicing with trench weapons, handling rifles, or maneuvering in open ground.

The First Division was without cannon, the artillery had gone to Valdahon to the firing school; but our "Chasseurs" had their own guns and were able to add some artillery instruction to the various lessons which their new comrades were eager to take advantage of.

General Pershing was often present at these maneu- 
vers. He always took occasion to express his opinion on the most practical methods of carrying on the fight. How often have we not heard him say: "Do not attach too much importance to trench warfare, mind your aim, have confidence in your rifle, and get expert with the bayonet."

The aggressive conceptions of the commander-in-chief suited the caliber of his men, hardy and keen for action.

For some weeks the Sibert division continued to profit by the experience of the French troops under a direct American command. This unit was reviewed on the eighth of September by President Poincaré and M. Painlevé, Minister of War, and as the departure for the front became more and more imminent, Marshal Joffre appeared at Gondrécourt to visit, before their entrance in the trenches, the first contingents which had answered his call.

The spectacle was impressive and moving. After the defile he said a few words of welcome and Godspeed which were translated into English and met by the acclamation of the American officers gathered around the French chief.

A few days later, the division was moved to the sector of Sommervillers, east of Nancy. Successively the battalions went into line intercalated with the French units and backed up by their own artillery which had arrived from Valdahon.

During the first days, the American batteries contented themselves with remaining in close touch with the French batteries which had been maintained in line. The French were entrusted with the direct covering of the infantry, but in case of attack, the Americans were to superpose their fire on that of the French, thus increasing the power 
of our guns without as yet assuming the difficult and delicate task of maintaining a constant liaison with the infantry troops.

Later on, as they became more expert in the field, the American batteries replaced the French and assumed the direct responsibility of liaison with their own infantry.

General Sibert's division was distributed as follows: The I 8 th Infantry Regiment, flanked by the canal MarneRhine and fronting toward Parroy, held the right end of the sector. Proceeding from south to north the I6th, 26 th, and 28 th regiments filled up the position, the left of the latter extending to the village of Arracourt.

It was at this point that the Americans fired their first shells into the German lines and captured, in the vicinity of Bures, their first prisoner. This honor fell to the I 8 th Infantry Regiment. Here also they met with their first losses; during a German raid against that portion of the front held by the 16 th Regiment. ${ }^{1}$ After a violent bombardment the enemy succeeded in reaching the firstline trenches where a desperate struggle ensued. During this hand-to-hand fight the Germans succeeded in capturing a few prisoners.

Soldiers and officers were eager to avenge this assault by one of equal vigor. Plans had been made, the men had prepared their attack which was about to be executed, when the division received orders to leave the sector. Nevertheless, the American soldier had already been able, in the course of numerous reconnoissances and scouting

1 The tomb of the first American killed in action was erected by subscription from the communes and the department of Meurthe et Moselle. The prefect of this department placed a Lorraine cross near the village of Bathélémont upon which is the following inscription: "Here rest the first soldiers of the United States to fall on the soil of France in the cause of Justice and Liberty." 
parties, to demonstrate his superiority over his enemy when they came to blows.

The last elements of the Sibert division were relieved on the twenty-first of November, and the whole unit was once more assembled at Gondrécourt to resume training. This time the instruction was of a different order, being limited almost entirely to concerted maneuvers in the open, and, when this second period was completed, the Americans were judged capable of holding alone a divisional sector.

The First Division, of which General Bullard now took command, was accordingly established with its headquarters at Menil-la-Tour, north of Toul, where the First Brigade, commanded by General Duncan, and reënforced by a large portion of artillery, relieved the French Moroccan division. The front thus occupied bordered the southern Woevre and stretched from the "Bois Carré," east of Seicheprey, to a pond in the vicinity of Bouconville village.

Here, framed in with the Thirty-second French Army Corps, the First Division soon made the enemy feel its presence. The artillery was extremely active, daring patrols operated nightly, as much with a view to "getting their hand in " as with the intention of taking prisoners.

The first of March, a German storming party consisting of 240 picked men from the " shock troops " and with all the material necessary to successfully carry out this kind of operation, attacked the "Bois Carré" which was held by a company of the I 8 th Regiment. The Americans, who had foreseen the attack, had taken the necessary precautions, so that the enterprise completely failed and the enemy left in our lines seventeen dead, several prisoners, a machine gun, and a flame thrower. 


\section{I22 The American Army in the European Conflict}

The First Division had thus already acquired the reputation of being a troop whose fighting value could be relied upon, and was soon to give even more positive evidence of the stuff its men were made of.

Some days later, when the Germans were carrying out their attack on the British right and were progressing toward Amiens, the division was withdrawn from the Woevre sector and transported by rail to the zone of active operations.

The Second Division, commanded by General Bundy, was the second to perfect its military training upon our front. Formed like the First of regiments belonging to the Regular Army but to which a large number of recruits had been added, ${ }^{2}$ this division had received its training on French soil. Having scarcely landed, it was immediately directed to the Bourmont zone and there, under the same conditions which we have described for the sister division, it prepared itself for active warfare. It was pronounced ready for combat about the middle of January, I9I8, and directed to the portion of the front comprised between the Spada Gap and les Eparges.

General Bundy's post of command was established at Sommedieue, near that of the chief of the Tenth French Army Corps, which was to frame in the American contingents.

From the moment of entering the line the men of the Second Division gave proof of courage and tenacity. On

2 Including a brigade of marines composed of two regiments which had arrived in France with the First Division, one of these had been training with General Bullard's troops, while the other was engaged in work on the line of communication where there had been a shortage in labor. The Second Brigade of the Second Division was made up with two regiments of regulars. 
several occasions the French command was obliged to moderate the ardor of these fresh troops. It was noticeable that every time an American division appeared in the front line to gain experience in what had been considered a "quiet zone" the calmness sought for was immediately broken up and the sector at once became animated; the foe was kept constantly on his mettle. Reconnoissances were multiplied, patrols were sent out in force every night, and on both sides raids were organized.

Two companies of the 9 th Regiment had been attacked near Mézey by a German battalion. This position held by the Americans presented many difficulties; moreover, when the French held the same ground in January, I9 I 8 , there had been serious question of abandoning it as too precarious.

The bombardment which preceded the German attack was particularly violent. A rolling barrage of great intensity accompanied the first assaulting waves which, on April I 5 th, at half after midnight succeeded in reaching the advanced outworks. The enemy's fire had scarcely ceased when the Americans emerged from their shelters with remarkable daring, and engaged in a desperate struggle calculated to give a splendid idea of their fighting qualities to their more experienced adversaries. In the blackest darkness all the ground for a moment occupied by the foe was reconquered. Seventy-two Germans dead were counted and on the American side there were but seven killed and nineteen wounded. When the roll was called ten men and a corporal were indeed missing, but not for long. Carried off as prisoners, at a given signal the little band, before reaching the German lines, turned upon their captors, seized their rifles, and made such good use 


\section{I24 The American Army in the European Conflict}

of them that they had little difficulty in regaining their own lines safe and sound.

The division whose turn now came to appear at the front was the Twenty-sixth, composed of National Guards recruited among the New England States. The chief of this division, General Clarence Edwards, his staff, and a small number of officers alone belonged to the Regular Army.

They had arrived in France at the end of October, I9 I 7, and had been sent to Neufchateau, where, in conjunction with the French Sixty-ninth, they completed their training after the same methods as their predecessors. We should, however, remark that at that period the American general headquarters of Chaumont was able to give particular and close attention to the progress of instruction of the troops, to correct the points of training which had been defective, and that the last comers were able to profit by the experience of the first divisions which had gone before.

When infantry and artillery were pronounced ready for trench work - that is to say, on the ninth of February - the Twenty-sixth Division passed into the organization of the French Eleventh Army Corps which, at this date, occupied a large sector north of the Aisne bordering the Chemin des Dames.

This portion of the front, the "Couvrel" sector, had remained relatively calm since the attacks of October, 1917. The entry into line of the American troops enlivened things considerably.

The French units were no sooner replaced than General Edwards' troops were subjected to a fierce localized attack which they succeeded in repulsing, showing them- 
selves on this occasion particularly tenacious; in resisting a bombardment of thirty hours, during which the German batteries rained thousands of toxic shells on the ground defended by the ro2d Infantry Regiment.

Numerous detachments from the Twenty-sixth Division were called upon to illustrate their offensive quality by frequent raids into enemy territory. One of these operations, executed by Franco-American troops, was so well conducted that twenty-two men and two German officers were brought back without the Americans having lost a man.

General Pershing had been following with closest attention each new occasion upon which contact was established between American troops and the enemy. For, although he attached but a reasonable importance to the loss or gain of a small trench element, each new enterprise of the sort served to test more vital things, whether he had been right in his previsions and justified in his decisions concerning the proper training for his soldiers. These events demonstrated that his estimation as to the daring and value of the American soldier in action had been perfectly correct.

During this period he was constantly at the front, visiting the trenches in order to form a personal impression of the morale of the troops, and from each new expedition he returned with a favorable one.

The faults which might be noted were those of men who were as yet somewhat green, and who showed excitement, agitation, sometimes an excess of zeal, but who were self-confident and strong in their conviction of being able to down their opponents.

The onlooker visiting the American advance posts was struck by the care and attention of the men on watch; 


\section{I26 The American Army in the European Conflict}

their gaze remained constantly fixed upon the enemy's line. As to the trenches, they were well kept up, the shelters clean and comfortable. At this period the American detachments, with their effectives still complete, were always able to dispose of a large number of workers, whereas the French were, after four years' heavy losses in the war, sadly lacking in workers.

In the beginning the American soldier was tempted to consume his cold provisions without waiting to have them cooked, but placed in contact with our troops he speedily acquired our habits in this regard and brought forward his field kitchens after the French fashion as close as possible to the firing line.

When the commander-in-chief or his chief of staff made a surprise visit to the sector they passed by the different parts of command established along the roads which lead to the trenches. It was rare, during these visits, for them to encounter any commander in one of these posts, for the officer in charge was usually himself inspecting the front in closer proximity to the foe. These rear posts were generally occupied merely by an officer on day duty. This was quite as it should be. General Pershing and General Harbord were glad to note the full consciousness of responsibility shown by their subordinates, whom they were sure to find at an early hour in the most advanced lines or near the batteries. It was noteworthy that the American officer not only fully realized his duty as commander, but understood that his rôle consisted also in the no less important one of instructor, especially among a large number of inexperienced troops.

During the whole period of training within view of the enemy the general headquarters at Chaumont remained in constant touch with the divisions thus engaged in 
sector; an officer of the operation section of the general headquarters detached with each unit remained in telephonic communication with the chief of staff.

Nor were General Pershing and his divisional commanders content merely with a close surveillance of their own troops. They were eager also to study and take advantage of French experience. Each time an important operation was projected on our side, General Pershing, at once informed, hastened to the scene of action. Those generals, also, whose troops were still in America, each put in three or four weeks in visiting our front to personally get in touch with the most modern warfare.

On the twenty-first of August, General Pershing, placed in an advanced observation post, followed the entire operations on both sides of the Meuse.

He found himself beside General Corvisart, whom he had known long before in Manchuria, and who was now commanding the Sixteenth Corps.

It was under their eyes that our troops carried the woods of Avocourt, the Mort-Homme-Hill, the Corbeaux, and Cumieres woods, seized the villages of Champ and Neuville, taking 4,00o prisoners and inflicting heavy losses on the troops of General von Etzel, who, by one of the curious coincidences of war, had also known General Pershing during his stay in Kuroki's army.

On the twenty-third of October General Pershing again watched our soldiers during a desperate assault against the powerful positions of Allemant and La Malmaison and that same day, accompanied by General Franchet d'Esperey, he traversed the battle-field, hardly as yet entirely conquered, in order to study the immediate effects of our artillery fire, which, on that occasion, had 


\section{28 The American Army in the European Conflict}

been the most precise, heavy, and efficacious of the entire war.

A few days only had passed since the entry into line of the Twenty-sixth Division when the Forty-second also was pronounced sufficiently prepared to take contact with the enemy. Consequently, General Menoher, who was in command, was placed with our Seventh Corps and it was in the ranks of this French force, whose front extended from Baccarat in the Vosges to the forest of Parroy, east of Lunéville, that the Forty-second in turn received its baptism of fire.

The Americans distributed their regiments and disposed them in depth formation, back by their own artillery, among the brigades of the Seventh Corps.

General Menoher's headquarters were established at Lunéville.

The elements of this division had been recruited among the National Guard belonging to twenty-six different States of the Union. They had already been obliged to interrupt their instruction several times since arriving in France.

In order to decongest the rear of the Lorraine front where a heavy enemy offensive was expected, the Fortysecond Division had been transported from the region of Vaucouleurs to that of St. Blin near Neufchateau, and later to that of Rolanpont not far from Langres. Nevertheless, in spite of these interruptions in training, General Menoher's division proved to be nowise inferior to those which had preceded it.

The trenches in the portion of the front where they were now engaged were sufficiently distant from those of 
the enemy to permit patrolling parties and scouting squads to circulate between the lines.

Our allies profited by numerous occasions of this sort to carry out successful operations, and they were extremely anxious to make some raids in force which were stopped by lack of munitions.

When compelled to renounce an independent action of this sort they would endeavor to participate in French raids, and we have seen American officers up to the rank of colonel accompany our troops, penetrate into the enemy trenches among our own soldiers, and even bring back prisoners.

In its turn the Forty-second Division was fiercely attacked. On the night of March 4-5th a company of the I68th Regiment posted near Badonvillers was assailed by an enemy greatly superior in force and advancing in four storming parties. The preparatory bombardment had been particularly violent and had allowed the enemy to penetrate into the American lines. After a fierce handto-hand struggle where rifle, automatic pistol, bayonet, and even knife played a part, the enemy was forced to retire without having made a single prisoner. The American casualties were thirty-two of whom twelve were killed including the company commander.

Some days later, when the I68th Regiment penetrated into the enemy lines, they found a paper upon one of the German dead acknowledging the failure of the raid of March 4-5th and containing the statement that the encounter of that day had cost the Germans fifty men.

General Pershing was visiting this portion of the front when the defenders of Badonvillers were leaving their trenches in the first line for a rest position. Men and 


\section{I30 The American Army in the European Conflict}

officers, although covered with mud from top to toe, thin, weary from loss of sleep during many nights, marched past their commander-in-chief with such a fine carriage and appearance that nothing could have given a better promise of what might still be expected from soldiers of this mettle.

Mr. Baker, Secretary of War, with a laudable zeal and a complete indifference to danger which would have done credit to a seasoned trooper, also visited the trenches where the American divisions under heavy bombardment, were becoming expert in the use of arms. On the nineteenth of March he inspected both the Forty-second and the First Divisions. His great desire was to be in close touch with the new life of the American soldier, and to make him feel that, after all, home was not so far away, to learn from his own mouth his present needs and his present desires.

"Tell me what you want and I will see, when I go back to Washington, that you get it. Criticize what is faulty in organization or victualing, I am here to see that it may be improved," said he to the private soldier in the trench as well as to the battalions assembled at the rear.

$\mathrm{He}$ neglected no opportunity of seeing all that was possible, when presenting himself to the French command in the various regions visited. He heard everywhere the same story: unanimous praise for the courage and vigor of the American troops.

On March 2oth he inspected the Second Division near Dieue, and would have continued further had he not been obliged to leave the front on account of important business which made his presence in London necessary. $\mathrm{He}$ was on his way to England and was consulting with Gen- 
eral Pétain at Compiègne, when, on the morning of the twenty-first the Germans launched their formidable attack against the British armies.

Thus on the day of this offensive, the Americans had four divisions at their disposal; that is to say, about I OO, OOO men already in the trenches who had seen active warfare and were in contact with the enemy. But as we shall see in the next chapter, the actual aid rendered by America during the German onslaught was not to remain limited to this number.

Before entering upon a description of the fighting during the spring and summer of I9I8, we must not fail to mention here the repulse of a considerable German force in the southern Woevre front which could scarcely be narrated elsewhere. Though it occurred somewhat later than the events above described, it could hardly be classed among operations of such magnitude as those recounted in the following chapters.

The Twenty-sixth Division which had been withdrawn from the Chemin des Dames on the eighteenth of March, was ordered to replace the First Division, when this latter, leaving the sector of Ménil-la-Tour, north of Tours, was rushed to the defense of our lines then closely menaced by the great German attack.

This relay was effectuated on the night of the second third of April.

The Twenty-sixth found itself stretched out as far as the Ailly Wood in the defensive position left by the Bullard division. On the twentieth of April, after an intense bombardment with shells of all caliber, which cut communication between front and rear, the 259 th German regiment in full force, backed by two or three com- 


\section{The American Army in the European Conflict}

panies of the 258 th Reserves, and troops selected from the best shock battalions, violently assailed the Americans in the vicinity of Seicheprey.

Fighting lasted all day and even into the twenty-first. After a fierce struggle, during which the ro2d Regiment, the same which had endured the gas attack on the Chemin des Dames, bravely sustained the shock, the part of the village of Seicheprey that the Germans had captured was rapidly reconquered and the entire first line was reoccupied. .

The losses were: Killed, 2 officers 56 men; wounded, 5 officers I 40 men; missing, 5 officers 22 I men.

An immediate inspection of the ground gave a clear idea of the violence of the struggle. Forty-one German corpses together with a great quantity of equipment of all sorts encumbered the ground. Grenades, mortars, helmets hastily abandoned bore witness to the disorder of the retreat of the attacking forces, under the strong pressure of the counter-stroke so unexpectedly dealt by these new and comparatively inexperienced American troops. 


\section{CHAPTER V}

PARTICIPATION OF AMERICAN FORCES IN THE SPRING DEFENSIVE AND IN THE SUMMER COUNTER-OFFENSIVE OF I9I 8

TOWARD the end of March, when the rapid German advance on Amiens and Montdidier assumed a menacing character, the Allies at length agreed to entrust the future conduct of war operations to a single head.

An attempt had already been made in this direction, but the scheme was discussed only to be abandoned after the Franco-British offensive of April, I9 I 7, when General Nivelle, for a certain period, commanded the large combined forces engaged in this operation. And subsequently, every time a similar project for the unification of command was suggested, the idea met with disfavor on the part of the British, and found few partisans in Italy.

Among the Americans, on the contrary, the plan met with unqualified approval, and they lost no opportunity to aid in putting it into effect.

From the time of his arrival in France General Pershing had been a warm advocate of a unified high command among the Allies, and Colonel House, during one of his brief visits to the Continent, discreetly seconded the measure, and many officers who arrived with the Expeditionary Forces expressed surprise that the plan had not already been realized.

Whole-hearted participation in the War Council at Versailles was indeed undertaken, but chiefly with the 


\section{The American Army in the European Conflict}

hope that the sincere effort of the American delegates would eventually bring about the desired end, without which these practical soldiers could see but a faint chance of victory. ${ }^{1}$

Great, then, was the joy expressed at Chaumont and in Washington when news was received on March $27^{\text {th }}$ that the choice of a generalissimo had at last been made and that General Foch had been raised to the supreme command of the Allied forces on the Western front. ${ }^{2}$

The news was hardly official when General Pershing hastened from his headquarters to those of General Foch at Clermont-sur-Oise, where a short but memorable meeting took place on the twenty-eighth of March. General Pershing, with a magnanimous self-effacement which must ever redound to his honor, placed the American forces under his command at the unqualified disposal of the new commander-in-chief of the Allied armies.

Illustrating, as it did, the complete concurrence of our most recent associate in the plan for the general welfare of the coalition, General Pershing's action met with universal approbation.

This rapid and far-reaching decision was all the more to the American general's credit in that it was so completely opposed to any selfish or ambitious interest.

Up to this time the commander-in-chief had carefully safeguarded the autonomy of the Expeditionary Forces. His policy had been to develop an American army whose

1 America was represented in the Supreme War Council by General Tasker H. Bliss, former chief of staff of the American Army.

2 When President Wilson learned of the unification of the Allied command, he expressed his satisfaction in the following words:

To General Foch: May I not convey to you my sincere congratulations on your new authority? Such unity of command is a most hopeful augury of ultimate success. We are following with profound interest the bold and brilliant action of your forces.

WOODROW WILSON. 
unity should tend to bring out the qualities of the American race to the best advantage, and, while desiring to see his own men profit by the hardly gained experience of the Allies to which end he studied eagerly the best strategical and tactical methods in use on the French and British fronts - he had jealously maintained the absolute integrity of the American Army.

In view, however, of the exceptional gravity of the situation, so suddenly developed, General Pershing did not hesitate to interrupt the accomplishment of the task he had assigned himself nor to turn over to the supreme allied command all the forces then at his disposal.

With that foresight which comes from a thorough psychological knowledge of his men, he recommended to General Foch the advisability of employing the American troops, as far as possible, in large units and of avoiding their distribution in small fractions.

For although the method of a so-called amalgam between French and American troops had been freely suggested as the best manner of conducting future operations, General Pershing wisely considered it as prejudicial to the best service of American troops in action. He therefore suggested that no detachment, inferior in number to the regiment or brigade, should be incorporated in a French organization. It was also his wish that no step should be taken which might complicate the task of regrouping his scattered contingents into an American Army at the earliest moment compatible with the exigencies of the situation.

In compliance with General Pershing's desires thus frankly expressed, it was decided to group the American forces after the following system:

Those divisions which already possessed their quota of 


\section{I3.6 The American Army in the European Conflict}

artillery and their own services were to go into action as a whole.

Those which lacked some proportion of material, but which had benefited by a fair amount of training and seemed physically fit, were to be utilized by regiment or by brigade framed in with a French division.

Those whose training was still inadequate were ordered to speed up preparation and carry on their instruction in a quiet sector of the front, thereby making large numbers of trained French troops, occupying such sectors, available for action.

To Generals Pétain ${ }^{a}$ and Pershing, acting in closest unison, was confided the difficult task of arranging the details of this complicated organization and, in conformity with their first step in its execution - the First Division, which had been holding a quiet sector in the region of Toul, was relieved on April 2, I9I8, by the Twenty-sixth and shortly after was ordered to entrain for the scene of active combat.

Since March 2 Ist German activity had been very marked on the section of the front toward which the First Division was directed, and events of exceptional gravity had occurred.

Indeed, by March 26th, the enemy had crossed the Somme south of Peronne, and at the end of the month their line more than took in Noyon, Lassigny, Montdidier, Bray-sur-Somme, and Bapaume. From this important sector the Fifth British Army had been hurled back by the enemy's lightning advance and practically annihilated. The situation appeared critical. How-

a Although General Foch was in command of the Allied forces, materiel dealings were directly carried on between General Pétain, commander in chief of the French army, and General Pershing, commander in chief of the American expeditionary forces. 
ever, from the twenty-third of March on, French units had been able to intervene and prevent further progress on the part of the enemy. The transportation of troops had been speeded up by every possible means, and it was hoped that a crisis had thereby been avoided.

Our troops took over the defense of the sector up to the line of the Somme, leaving both banks of the river to the guard of the British armies which still remained intact.

By the time the First American Division had detrained in the vicinity of Meru-Pontoise, the situation of the Allies was already looking more hopeful. General Fayolle, at the head of the group known as the "reserve group of armies," held the enemy in check, with the First French Army under General Debeney facing east on the line from Villers-Bretonneux to Montdidier, while the Third Army (General Humbert) was fronting north between Montdidier and Noyon.

Back of this group, General Micheler's Fifth Army was placed in reserve in the zone between Beauvais, Meru, and Pontoise, barring the road to Paris.

This army of General Micheler's was to serve as a reservoir from which General Fayolle might draw fresh relays of troops; it also served as a sort of training school for the new units assigned to it and was called upon, in this capacity, to prepare the First American Division for the new system of semi-open warfare which was being inaugurated at the front. ${ }^{3}$

To this Fifth French Army the American division was accordingly confided immediately after having been detrained. Mention has already been made of this

3 The Fifth Army was at the disposition of General Pétain. 


\section{I38 The American Army in the European Conflict}

splendid unit, the first of the kind which America had prepared for action. ${ }^{4}$

We have described its training at Gondrécourt and also its first contact with the enemy while operating in the Lunéville sector. We have observed its stay in the southern Woevre, between the Bois d'Ailly and the Bois Mortmare at the time when it held this sector of our line unassisted.

Both physically and morally, the First Division now appeared in perfect fighting trim; at its head was General Bullard, a future army commander. Most of the majors and captains who surrounded him were, before the end of the war, to be regimental commanders or hold important positions in the General Staff. Most colonels in command of regiments at this time were future division commanders; the chief of artillery was to be at the head of an army corps before the lapse of many months.

Presenting as it does so fine an example of perfect unity, splendid fighting spirit, and high morale, this unit, which produced such a number of high ranking officers, may be profitably studied.

${ }^{4}$ Order of Battle of the First Division at the date of May r, 1918.

Major-General Robert L. Bullard, Division Commander

First Infantry Brigade

Brigadier-General Geo. B. Duncan

16th Infantry Regiment

Colonel John L. Hines

I8th Infantry Regiment

Colonel Frank Parker
Second Infantry Brigade Brigadier-General B. B. Buck 26th Infantry Regiment Colonel Hamilton Smith 28th Infantry Regiment Colonel Hanson E. Ely

First Artillery Brigade

Brigadier-General C. P. Summerall

5th Artillery Regiment

Colonel Dwight E. Aultman

6th Artillery Regiment

Colonel Cortland Parker

7th Artillery Regiment

Colonel L. R. Holbrook 
The rumor no sooner became current that a few days only remained for training and preparation than every one redoubled their efforts. The whole division worked feverishly, great activity was shown in picking up the latest "tips" which, at such a moment, always filter through the front lines. One and all were keen after the latest bits of information, centralized and spread by the staff of General Micheler's army, and no sooner did a French liaison officer appear on the horizon than he was beset for an account of the new warfare without trenches which had now begun.

Fields, roads, and farmyards are now the scene of more or less important maneuvers, during which special care is always given to the testing and study of every method of signalling.

The division realized at once the paramount importance of adequate linking between artillery and infantry units by means of telephone, visual signalling, panels, rockets, flashlights, all of which were practiced. General Summerall, commanding the divisional artillery, personally supervised these exercises, constantly visiting the smaller infantry units in order to assure himself that nothing was left undone which might keep the infantryman thoroughly informed of the methods which the artillery would be called upon to use in battle to maintain communication between the two branches of the service.

According to his ideas, every commander of a more or less important artillery unit, whose mission was to sustain or protect the advance or retreat of the infantry, had to keep in constant touch with the officer commanding the infantry unit involved, through a series of relaying posts organized according to the lay of the land, but generally stationed some six hundred yards apart. 


\section{I40 The American Army in the European Conflict}

These posts consisted of one officer or non-commissioned officer; several telephone operators, signallers, skilled repairers, runners, and even sometimes cyclists. Each post was provided with all the equipment necessary for the speedy transmission of messages. Thanks to this system of relays - a veritable human chain - the artillery and infantry were effectively linked during action. As the first division possessed a large number of noncommissioned officers and men, both in artillery and infantry formations, it was easy to establish a very strong liaison 'organization, and to it both General Bullard and General Summerall attribute in no small measure the success of the First Division.

One difficulty remained, however, by no means easy to overcome and which study could not remedy. This was the scarcity of horses.

All the batteries were short of animals and many of those on hand were in poor condition. This situation caused grave anxiety to the artillery commander and the officers of his staff. Fodder was scanty and arrived at irregular intervals; an epidemic of mange, frequent under such circumstances, made serious inroads, and it was impossible to invent any means of bettering the situation, of which the American high command was, of course, fully aware.

It must suffice to remark here, that the same sense of patriotic duty which made it necessary and right to keep the American headquarters thoroughly informed as to the unsatisfactory state of the artillery horses, made it equally natural and laudable to conceal it from the French command. The Americans did not wish to give General Micheler any reason for declaring the division unready 
for action and postponing an entry into the fight for which every one was eager.

At last, after a combined maneuver, at which General Pershing and the commander of the Fifth Army were both present, the First American Division was declared "ready and fit for action." Marching orders were issued on April I 6th, and the following day, after having been thrilled by a stirring address from the commanderin-chief the division set forth upon the road to join the Sixth French Corps. ${ }^{5}$

In the meanwhile, and somewhat to the disappointment of the eager American troops, the news from the front was steadily becoming more and more reassuring. The enemy's line now seemed almost stabilized, with the exception of the front toward Hangard-en-Santerre and Villers-Bretonneux where these villages were still changing hands, but the intensity of the fighting was decreasing as it approached Montdidier.

It seems due to his American comrades that one of the writers of these pages should here recount some of the negotiations with which he was, at this time, entrusted.

As the American troops were nearing the sector of Mesnil-St. Firmin they became aware that they were being sent to a comparatively quiet portion of the front held by the First Army. At once several American officers came to beg their French comrade to use all his influence with the French military authorities, in order to obtain a change of orders which would direct the division into the vicinity of Hangard-en-Santerre which was still the scene of desperate fighting.

5 The Sixth Army Corps was relieved a few days later by the Tenth. Thus General Vandenberg had control of the operations in this sector during the American operations which are here examined. 


\section{The American Army in the European Conflict}

The sector which General Debeney had assigned to the American troops (Villers Tournelle-Mesnil St. George near Montdidier) was, on the contrary, if not altogether quiet, at least apparently stabilized, and the front confided to the division did not exceed three miles in length.

The enemy had ceased his infantry attacks, but continued to use his powerful artillery in a prolonged, harassing fire or in violent concentrations upon certain points. $\mathrm{He}$ seemed determined, while resigned to making no further advance, to hold every inch of ground in his possession, especially the heights of Cantigny, dominating the valley of the Avre which he had crossed. From those heights he enjoyed a commanding position, and one which gave him every advantage for concealing the movements of his troops.

The mission entrusted to the First Division was not, however, a strictly passive one. General Bullard's men, while organizing the sector for a strong defense, had orders to assume a semi-aggressive attitude which might make their presence felt and to prepare for an offensive action should orders for attack be issued. We are fully justified in declaring here that the First Division acquitted itself admirably of this dual rôle.

Hardly had the troops deployed on the ground allotted to them than the men began vigorously to " dig themselves in." One brigade occupied the first positions, the other was held in reserve. Three lines of trenches with communications were at once established, battery emplacements were prepared, others perfected, advantage being taken of every hollow of the ground.

The artillery lost no time in assuming an aggressive attitude. General Summerall's brigade, reënforced by a 
regiment of French 75's, fired not only all the shells allotted to it by the American command, but also all the ammunition which they could obtain, "due to exceptional circumstances," from the French authorities.

The opposing batteries immediately came to grips. Concentrative and destructive fire thundered with equal violence from both sides. But gas shells were employed with a frequency which we unfortunately were unable to rival, as the Germans, at that time, disposed of ample supplies of yperite.

Toward May I5th, the American gunners began to secure a distinct advantage, and the hour when the infantry was to have its turn was not now far distant.

General Bullard had received orders to storm the important position of Cantigny, as the capture of this fortified village would wrest from the enemy a dominatin? point of vantage, and, if successfully carried out, would even endanger his line on the left bank of the Avre. At the same time, it would provide the Americans with advantages for observation into the deep valley of this river which runs winding from Montdidier to the vicinity of Amiens.

The plan of attack, as conceived by the division commander and elaborated by his youthful staff, was submitted to the French high command, and it may readily be inferred that the pupils here proved equal to the masters, for no changes in the original plan were suggested. And it now remained only to carry out the first attack with limited objectives to be undertaken by American troops on our front.

General Pershing appeared on the eve of battle to investigate the operation plans and await the result of this first experiment. 


\section{I44 The American Army in the European Conflict}

On the twenty-eighth of May, shortly after daybreak, following a powerful artillery preparation brief and well directed, the rolling barrage began to thunder, sweeping the ground in front of the advancing waves of infantry, and striking progressively further and further as the foot soldier pushed forward.

Some French tanks, mingled with the assaulting troops, skilfully aided in their progress. In short, the attack, carried through absolutely according to schedule, was a complete success with all objectives reached.

The spectacle, as witnessed from the advanced artillery observatories, was of impressive grandeur; nor could there be any doubt as to the conclusion which must inevitably be drawn by those who were there to see it.

The American army had brought into the field not numbers only, but real technical value and tactical skill. It was easy to deduce from this experience that American infantry was more fitted for an attack carried out in depth than for one with limited objectives. The regiment which took Cantigny held the position with difficulty, being subjected to a heavy bombardment entailing pretty severe losses. The net results of the day were, however, greatly in excess of the most sanguine expectation. Three hundred prisoners were counted.

The enemy, infuriated at finding his forces hurled from an important position by young and hitherto inexperienced troops, resolved to regain his lost ground, and at once ordered a powerful counter-attack. The two columns which were charged with this enterprise were caught under the withering fire of the Franco-American guns, and practically annihilated.

The little village of Mesnil-St. Firmin, divisional headquarters, was for a few days the scene of extraordinary 
animation. Not only was General Pershing present to extend his congratulations to the troops, but all the commanders of neighboring French divisions and army corps also added their felicitations. Hardly had those who were stationed in close proximity arrived upon the scene, than the French commander-in-chief made his appearance, followed by the Premier, M. Clemenceau, both eager to assure their American associates of the profound admiration which such a success had inspired throughout the land. ${ }^{6}$

The conquered position was immediately consolidated; but, as is customary after an affair of this sort, the enemy guns hammered for several days against the ground recently occupied. Then after a slight let-up in the bombardment, the sector once more assumed the normal calm of a stabilized front.

On June $5^{\text {th }}$, however, there was such a strong recrudescence of activity upon the German side that it led to the belief that a fresh and powerful offensive was about to be launched against our lines.

The losses to which the First Division was subjected during the Cantigny affair comprised 45 officers, of whom I 3 were killed and I,022 men, of whom i 85 were killed. ${ }^{7}$

6 The Twenty-eighth Regiment of the First Division was mentioned in the following terms in the orders of the French Army after the battle of Cantigny:

"This regiment is animated by a magnificent aggressive spirit. On the twenty-eighth of May it attacked under the orders of Colonel H. E. Ely with irresistible dash a strongly fortified position, reached all objectives, and held all the ground gained."

7 The average daily losses in this sector were twenty-five men, which losses may be considered inevitable, considering the necessity of the defensive organization which had to be created under the enemy's guns. During these days given up to digging entrenchments, the troops displayed qualities of zeal and courage which are beyond praise.

One colonel whose post of command had been subjected to continuous bombardment refused to quit his position which he maintained during 
I46 The American Army in the European Conflict

General Bullard's division continued to occupy the Mesnil-St. Firmin sector, which they hastened to improve from the defensive standpoint, and which later extended as far as Grivesne. The officers were now anxious to give their men a well-deserved rest and to give the benefit of their experience to their troops upon the training ground and thus prepare them for future and more important attacks.

There seemed every reason to believe that the First Division would be speedily relieved, especially as the Second had now recently arrived in the immediate neighborhood, and was expected soon to replace the sister unit.

Transferred on May 8th from the Eparges-Spada front, this unit had entrained near Bar-le-Duc and had been transported to billets near Chaumont-en-Vexin, in order to perfect its training.

Like its fellow, the Second Division now passed into the ranks of the Fifth Army, where it at once produced a like excellent impression.

Although it perhaps lacked a little of the cohesion of its predecessor, General Micheler, in watching the maneuvers, was perhaps even more struck by the fighting spirit of General Bundy's men and their aptitude for aggressive action. ${ }^{8}$

The division commander, whom we shall find later on fifteen days under a rain of shells of all calibers as well as gas bombardment. During this period his lieutenant-colonel was killed.

${ }^{8}$ Order of Battle of the Second Division at the date of June I, I9r8.

Major-General Omar Bundy, Division Commander

Third Infantry Brigade Brigadier-General E. M. Lewis

9th Infantry Regiment

Colonel Leroy Upton
Fourth Infantry Brigade, Marines

Brigadier-General J. G. Harbord

5th Regiment, Marines

Colonel A. Catlin 
at the head of an army corps, was justly proud of his two infantry brigades.

One of them (the Fourth) was already famous in America as the "Marines." It was made up of the 5 th and 6th regiments forming the Fourth Brigade, and may be compared to our French Colonial infantry. These picked troops were under the command of General Harbord, recently chief of staff to General Pershing, whose name will frequently recur in these pages not only as a first-rate leader of men in the field but also as an able and expert organizer.

The other brigade (the Third) under General Lewis, whom we shall find at the close of hostilities in command of a division, included the 9 th and $23 \mathrm{~d}$ regiments of regulars. Admirable in their "tenue" it was easy to see that these men were eager to rival the famous marines.

The artillery brigade, whose equipment was now complete and which also had the good luck to possess horses in fair condition, was commanded by General Chamberlaine, later head of the Railway Artillery Reserve.

Thus constituted, the Second Division was marching by road to join the First French Army, when, on the night of May 29-3oth it suddenly received order to deflect from its course and to proceed rapidly toward Lizy-sur-Ourcq.
23d Infantry Regiment
Colonel Paul B. Malone
6th Regiment, Marines
Colonel W. C. Neville

Second Artillery Brigade

Brigadier-General W. Chamberlaine

I2th Artillery Regiment

Colonel M. McCloskey

15th Artillery Regiment

Lieutenant-Colonel J. R. Davis

17th Artillery Regiment

Colonel A. J. Bowley 
The infantry was to be moved by trucks, the artillery by rail.

General Bundy ordered his brigade commanders to report at Meaux where they would receive further instructions.

Grave and unforeseen events had indeed taken place, and the Second Division together with other French units were suddenly called upon to face a new invasion.

On the morning of May 26th, the English and French divisions in line on the Chemin-des-Dames had been unexpectedly attacked and thrown back.

The retreat of our Sixth Army and the rapid advance of General Von Boehm's Seventh Army operating in the vicinity of Soissons, and General Von Below's First Army, the left wing of which extended almost to Rheims, placed our lines in serious peril.

The towns of Soissons, Fère-en-Tardenois, and the villages on the Marne from Châtillon to Château-Thierry, successively fell into the enemy's hands. A front of thirty-five miles, extending from the last-named locality to the neighborhood of Fontenoy-sur-Aisne, was thus constituted facing the French capital. This moving front once more menaced Paris, distant some fifty miles only, and which was daily subjected to long-range artillery fire and nightly to frequent air raids. General Mangin's Tenth Army faced the northern part of this line; the French Sixth Army the southern section.

Such were the circumstances under which the Second American Division was called upon to deploy along the northern bank of the Marne, astride of the main ParisMetz highroad and given the honor (this expression figures in the American daily report of operations) of barring the enemy's access to the capital. 
If the troops of General Bullard had been, as we have seen, the first great American unit to inaugurate the war of semi-movement, those of General Bundy were about to inaugurate genuine open warfare. No trench was dug on the terrain of their future exploits.

At Meaux, General Bundy's brigade commanders received new instructions, but under the circumstances which prevailed, these were necessarily modified more than once. In the streets, great disorder reigned. A heavy aërial bombardment had taken place the night before. The roads leading to the town were encumbered with the retreating and advancing troops. Convoys of peasants, seeking refuge from the invading hordes, blocked the ways. In fact to the uninstructed and nonmilitary observer, we seemed to be again facing the conditions which had been witnessed before the first battle of the Marne.

When we consider the enormous difficulties with which General Bundy's troops were confronted, the uncertainty of debarkation at the designated points, multiplicity of counter-orders, all the troubles inherent to the relief of forces who speak different languages and the ignorance prevailing in regard to the enemy's exact whereabouts, we may be astonished at the comparative order with which the Second Division was deployed and made ready for action.

The troops were at first held in reserve behind the French Forty-third Division, but on the second of June they went through and took contact with the enemy upon a wide front of some seven miles. One regiment (the Twenty-third) belonging to the Third Brigade and about two battalions of the marines had been detailed to fill a gap in the French line near Coulombs. But on the fourth 


\section{I5O The American Army in the European Conflict}

of June these units were reassigned to the American division which, at that time, occupied a front not exceeding five miles in length. ${ }^{9}$

During these first sanguinary engagements, the fighting took the form of infantry skirmishes, while the artillery sought its positions and stored its ammunition. The American troops at once gained the upper hand, and, thanks to the accuracy of their rifle fire and to their superiority in attacking with the bayonet, they bent back the German line, taking Bouresches, but leaving the enemy in possession of the environs of Vaux, Bouresches railway station, Belleau Wood, and Hill I26, south of Torcy.

The two American brigades found themselves in close proximity. General Harbord with his post of command at the Ferme des Loges, held a two-mile front north of the Paris-Metz road; General Lewis, with his post of command at Domptin held the portion of the line extending from this highroad to Hill 204, the latter not included. The infantry regiments were, generally speaking, disposed in depth; usually one battalion was in line, one in reserve, while the third formed part of the "divisional reserve."

General Chamberlaine's artillery had been reënforced by two regiments of French 75's and one group of 155 's.

Such was the situation when General Bundv, whose post of command had been transferred from Montreuil-auxLions to the Genevrois Farm, began, under the orders of the Twenty-first Army Corps a methodical attack aiming at the capture of several fortified positions.

9 When the Second Division arrived this sector was already occupied by the Twenty-first Army Corps under General Degoutte and belonged to the Sixth Army with headquarters at Trilport. On June 15th, General Degoutte took over the Sixth Army and General Naulin was charged with the command of the Twenty-first Corps, which was replaced on June 2 rst by the Third Corps under General Lebrun. 
The first of these objectives was the Belleau Wood, which presented a vast mass nearly rectangular in shape, and apparently thickly planted everywhere with lofty trees. The border of the forest facing the Americans extended for about I, IOO yards, concealing behind its thick screen of foliage many clearings and hollows overgrown with brush and underwood; scattered among these thickets were to be found large rocks and bowlders which offered veritable strongholds on which the enemy had mounted machine guns and under which he had installed shell-proof retreats in the form of natural caves and grottoes.

The Germans had taken advantage of the natural strength of this position and had organized it artificially with method and rapidity. Nevertheless, on the morning of June Ioth, the Second Division, after bombarding the whole of Belleau Wood, carried a portion of it by assault.

In the course of the artillery preparation and during the infantry advance, General Chamberlaine's guns fired 40,000 rounds, of which I 2,000 were large-caliber shells, so that, when the American troops succeeded in gaining a footing in an important section of the wood, a large number of German dead were found, and roo prisoners, together with many machine guns, were captured. A very successful day. On the eleventh the central part of the wood was taken, together with 400 prisoners and 37 machine guns.

The enemy at once attempted to repair the breach made in their line by launching two strong counter-attacks on the twelfth and on the fifteenth.

It is very likely, also, that offensive actions were attempted by the Germans on the fourteenth and nineteenth, but on these two occasions the assaulting waves were not 


\section{52 The American Army in the European Conflict}

actually seen by us, so that the enemy's intentions can be only guessed at. Many movements were observed, both on his first and second line, and some aggressive action was manifestly contemplated. After violent artillery fire from both sides the original lines remained unchanged.

At any rate, from the nineteenth of June the Germans seemed to have renounced any intention of retaking Belleau Wood and contented themselves with reënforcing the troops who still held the northern part of the position.

On the morning of the twenty-first, the marines undertook to mop up this corner. Confident in their unsupported strength and individual courage they attempted to storm this stronghold without any serious preparatory bombardment. But they had underestimated the strength of the enemy's defenses and they failed. On the twenty-fifth the operation was resumed with other methods.

The infantry was withdrawn for some distance, thus permitting the artillery to sweep with its fire the enemy first line. The result was a complete success; the narrow strip of woodland which constituted the Germans' last defense in Belleau Wood was captured in fine style together with 309 prisoners. American casualties were slight. ${ }^{10}$

10 The marine brigade was mentioned in the orders of the Sixth Army in the following terms:

Fourth Brigade Infantry (Marines).

Thrown into a battle already in progress, and on a front which was being violently attacked by the enemy, at once proved itself to be a unit of the very highest class. No sooner entered into line than the brigade in conjunction with the French troops checked a fierce assault upon an important section of our position and at once began a series of offensive operations, in the course of which, thanks to the brilliant courage and dash, the vigor and tenacity of its men who were discouraged neither by fatigue nor losses, thanks to the energy of all its officers, and thanks especially to the personal action of Brigade Commander General James G. 
In the course of these operations, General Harbord's brigade had taken many prisoners and given the foe a high opinion of the fighting quality of the American troops. This fact was confirmed by frequent conversations with German captives, who had had disagreeable personal experience of the vigorous methods of the American soldier in action and who appeared much impressed by his work. Chance also placed in our hands a German army bulletin containing an interesting report upon the quality of the Second American Division of which the following is a translation:

"The Second American Division must be considered a very good one and may even perhaps be reckoned as a storm troop. The different attacks on Belleau Wood were carried out with bravery and dash. The moral effect of our gunfire can not seriously impede the advance of the American infantry. The Americans' nerves are not yet worn out.

"The qualities of the men individually may be described as remarkable. They are physically well set up, their attitude is good, and they range in age from eighteen to twenty-eight years. They lack at present only training and experience to make formidable adversaries. The men are in fine spirits and are filled with naïve assurance; the words of a prisoner are characteristic 'WE KILL OR WE GET KILLED.'”

The marines had hardly completed their conquest ${ }^{11}$ when General Lewis' staff began to work out a plan for

Harbord, every effort was crowned with success. In close touch with one another both regiments with their machine-gun battalion realized during ten days of incessant fighting (from the second to the thirteenth of June, I918) over extremely difficult ground, an advance varying from $\mathbf{r}, 500$ to 2,000 meters on a four kilometer front, capturing important material, taking over 500 prisoners, inflicting severe losses upon the enemy, and seizing two strongholds of paramount importance: the village of Bouresches, and the strongly fortified position of Belleau Wood.

11 Sixth Army. General orders.

Headquarters, June 30 , 1918.

In consequence of the brilliant conduct of the Fourth Brigade of the 


\section{54 The American Army in the European Conflict}

the capture of Vaux Village. It may be considered as a model of its kind.

It was not possible to carry out this operation before July Ist as it necessitated the shifting from left to right of the battle-field of an entire artillery regiment. But, at this date, the village was easily carried.

The preparatory bombardment was formidable, the advancing lines of infantry followed the rolling barrage at a distance of less than a hundred and fifty yards. Six hundred prisoners were taken, and the losses were quite insignificant when compared with the results achieved. ${ }^{12}$

Up to the tenth of July, on which day it was relieved by the Twenty-sixth Division ${ }^{13}$ arriving from the Woevre

Second Division, U. S., in the taking of Bouresches and the important stronghold of Belleau Wood, hotly contested by the enemy in force, the general in command of the Sixth Army has decided that henceforth official documents concerning this action shall replace the name of Belleau Wood by that of Wood of the Marine Brigade.

12 Following the capture of Vaux village, the Third Brigade was cited in general orders of the Sixth Army as follows:

"During the operations north of the Marne between June $\mathbf{I}$ and July 2; 1918, this brigade, stimulated by the energy of its commander, General Lewis, and brilliantly led by its officers, careless of the heavy losses sustained, advanced valiantly and carried Vaux in a fierce hand-to-hand combat, also the Wood of La Roche, giving a splendid sample of aggressive spirit, abnegation and contributing in no small measure to the victory which caused the enemy to evacuate French territory and eventually constrained him to ask for an armistice."

13 Order of Battle of the Twenty-sixth Division at the date of July ro, 19 r 8 .

Major-General Clarence R. Edwards, Divisional Commander

Fifty-first Infantry Brigade

Brigadier-General Peter E. Traub

rorst Infantry Regiment

Colonel E. L. Logan

Iozd Infantry Regiment

Colonel J. H. Parker
Fifty-second Infantry Brigade

Brigadier-General Chas. H. Cole

Colonel Frank M. Hume

Iofth Infantry Regiment

Colonel Geo. H. Shelton

Fifty-first Artillery Brigade

Brigadier-General D. E. Aultman 
front, the Second Division had been engaged for over a month in ceaseless fighting; 8,500 sick and wounded had been sent to the rear during this time and I, 250 dead had been left on the field. Its mission was more than fulfilled; the enemy's advance had been stopped and the maintenance of his positions seriously menaced by the taking of Vaux, and Bouresches and the Belleau Wood where I, 400 prisoners had been captured. The casualties of the enemy were large and distributed among five divisions, which in their entirety or in detachments had been successively opposed to the Second Division.

An American journal of operations now before us estimates that the commencement of the German withdrawal on July I 8 th was a direct consequence of the action above described. There is excellent reason to sustain this opinion.

Dating from July $4^{\text {th }}$ at noon, the Second Division was transferred to American command. The First Army Corps (General Liggett) with his headquarters at Château de Lagny, then relieved the Third French Army Corps.

This First American Army Corps ${ }^{14}$ created by general

Iorst Artillery Regiment

Colonel J. H. Sherburne

rozd Artillery Regiment

Colonel Morris E. Locke

Iozd Artillery Regiment

Colonel P、 D. Glassford

14 Order of Battle of the First Army Corps (American) at date of July $4,1918$.

Major-General Hunter Liggett, Corps Commander

Colonel Malin Craig.......... Chief of Staff

Major George Grunert ......... Chief of the First Section (G-r)

Lt.-Col. R. H. Williams......... Chief of the Second Section (G-2)

Colonel A. E. Barber........... Chief of the Third Section (G-3) 
I56 The American Army in the European Conflict

orders dated January I 5 , I9 18 , had, up to that time, been operating at Neufchateau with administrative control over the First, Second, Twenty-sixth, and Forty-second Divisions while these units.were stationed in the respective sectors that have already been described.

The First Corps was now to administer the First, Second, Third, Fourth, Twenty-sixth, and Twenty-eighth Divisions. When General Liggett took over the tactical command of the front held by the Second American and the One Hundred and Sixty-seventh French Divisions, the artillery of the First American Corps under General Lassiter relieved the artillery of the French Third Corps.

American participation in the defensive battle of June, 1918, was not, however, confined to the First and Second Divisions.

The Third Division also (General Dickman) ${ }^{15}$ was hurriedly thrown into the mêlée and afforded powerful assistance.

This unit was completing its training in the Chateau15 Order of the Third Division at date of May 31, 1918.

Major-General Joseph T. Dickman, Divisional Commander

Fifth Infantry Brigade

Brigadier-General Fred W. Sladen

4th Infantry Regiment

Colonel Halstead Dorey

7th Infantry Regiment

Colonel T. M. Anderson
Sixth Infantry Brigade

Brigadier-General C. Crawford

3oth Infantry Regiment

Colonel Edmund L. Butts

38th Infantry Regiment

Colonel Ulysses G. McAlexander

Third Artillery Brigade

Colonel Wm. M. Cruikshank

Ioth Artillery Regiment

Colonel Chas. Rees Lloyd

I8th Artillery Regiment

Colonel Otho W. B. Farr

76th Artillery Regiment

Colonel IV. C. Rivers 
villain area (near Bar-sur-Aube) when orders arrived to relieve the Twenty-sixth American Division in the southern Woevre sector. Preparations to this effect were well under way when new orders were received transferring it to the disposal of the French high command.

In conformity with these new instructions, the division began to move on May 3 Ist. The infantry entrained for Provins-Montmirail; while those elements which were provided with motor trucks were directed toward Condéen-Brie by road. The division was as yet without its engineer regiment, nor was the artillery to be available for another month.

Hardly had General Dickman's troops detrained, when the division was assigned to the group of armies of the Center. Thence it passed under the command of the Sixth Army which, in turn, ordered the Third Division to reënforce the Thirty-eighth French Army Corps whose front extended from Château-Thierry to Dormans.

The first detachment of the Third Division to go into action was the motorized seventh machine-gun battalion. Without making any halt at Condé, as it was supposed to do, the battalion pushed on directly to Château-Thierry where it arrived on the evening of May 3 Ist.

The following morning, mixed with General Marchand's troops, it gave signal service in repulsing an enemy attack delivered in the town of Château-Thierry, by keeping the vicinity of the bridge over the Marne under constant fire, and effectually preventing the passage of the river at this point.

The Fifth and Sixth Infantry Brigades which composed this division went into action successively, generally battalion by battalion. Posted above Château-Thierry, the troops facing the enemy dug themselves in and pre- 


\section{58 The American Army in the European Conflict}

pared to hold the ground obstinately. Those posted downstream were placed in the second line guarding the passage over the different bridges.

Thus the division after June ist was split up. But the separate units were extremely active, and all gave an excellent account of themselves in hardy scouting, daring patrol duty, and audacious minor operations, as well as by their vigor in trench construction while occupying the second lines.

The, 7 th Infantry Regiment, for example, after holding part of the front assigned to the Thirty-eighth Corps, was transferred to the One Hundred and Sixty-fourth Division to guard the bridge near Nanteuil. Thence it passed under the orders of General Bundy, who made use of it to relieve, for a few days, one of the regiments of marines which had been in action at Belleau Wood.

The 3oth Infantry Regiment shared with the Tenth French Colonial Division, in the attack on Hill 204 west of Château-Thierry. Nor did the division commander remain inactive. General Dickman was placed by General de Mondésir at the head of a reserve which the commander of the Thirty-eighth Corps had organized behind the lines. He later took command of the American troops grouped in the center of the Thirty-eighth Corps, between Hézy and Chierry. This detachment had, at this moment, the strength of a full brigade, spread out on a front of five miles and afterward it became important, serving, as it did, for a nucleus around which the Third Division was regrouped after having lost, in the course of these operations near the Marne, 34 officers and 822 men killed or wounded.

In describing the rôle played by the First Division in the Cantigny sector, we have attempted to indicate the 
part taken by the Americans in those operations which finally checked the first German drive of the spring of I9 I 8 .

In recording the actions of the Second and Third Divisions in the Bois-de-Belleau sector and along the Marne we have shown the assistance given by the American Expeditionary Forces to the allied cause in the affairs which finally brought the enemy's second offensive to a standstill. It now remains to examine in what manner the American troops took part in the counter-offensive which compelled the enemy, for a second time, to abandon the banks of the Marne.

The general plan of the battle is well known. It consisted for us in an obstinate resistance along the front held by the fourth and fifth French armies (from the Argonne to Château-Thierry on the Marne) during the German attack. Once the enemy forces were sufficiently engaged, we were ourselves to assume the offensive, and with the Tenth and Sixth Armies break through the German right flank.

The Forty-second and Third American Divisions, with several units of the Twenty-eighth, took part in the strictly defensive action of July I 5 th.

The First, Second, Fourth, and Twenty-sixth Divisions were part of the forces engaged on July i 8 th when the attack was launched and afterwards coöperated in the exploitation of the victory.

The Third, Twenty-eighth, Thirty-second, Fortysecond, and Seventy-seventh Divisions came into line in the course of the fight.

On the fifteenth of July, when the enemy started their general attack from the Argonne to the Marne, precisely within those limits where the French command expected 
160 The American Army in the European Conflict

them to strike, the American troops were disposed as follows :

The Forty-second Division ${ }^{16}$ in the region near Suippes was placed in support of the One Hundred and Seventieth and Thirteenth French Divisions. The defensive system of this Champagne sector included a first position which was not to be occupied in force, the defenders being authorized at certain points to withdraw should the enemy's pressure become intense; an intermediate position, where energetic resistance must be offered, and a third, which must be held at all costs. The artillery, under cover of this third line, reënforced the batteries of the two French divisions which, at the start, were placed in the first and intermediate positions while the American division held the third position with its two brigades in line (the Eighty-third on the right behind the French One Hundred and Seventieth Division, the Eighty-fourth Brigade on the left behind the Thirteenth French Division).

16 Order of Battle of the Forty-second Division on July ro, rgr8.

Major-General Chas. T. Menoher, Division Commander Eighty-third Infantry Brigade Eighty-fourth Infantry Brigade Brigadier-General M. J. Lenihan 165th Infantry Regiment Colonel Frank McCoy I66th Infantry Regiment Colonel Benson W. Hough Brigadier-General R. A. Brown I67th Infantry Regiment Colonel Wm. P. Screws I68th Infantry Regiment Colonel E. R. Bennet

Sixty-seventh Artillery Brigade

Brigadier-General C. McKinstry

Ifoth Artillery Regiment Colonel Henry J. Reilly I5oth Artillery Regiment Colonel R. H. Tyndall I5Ist Artillery Regiment Colonel George E. Leach 
These dispositions, made when the Forty-second Division entered the line on July 5 th were altered subsequently because of the German attack having been delayed longer than was expected. Three American battalions were transferred to the intermediate position; and thus posted, the Forty-second Division, on July I 5 th, met the German onslaught.

Meanwhile on the Marne the Third Division, now entirely reassembled, and in possession of its own artillery reënforced by two battalions of French 75's, two of I05's, and one of 155 's was stretched along the Marne from Jaulgonne to the immediate vicinity of Château-Thierry (from Mezey to Nesles inclusive).

The four regiments of the division were ranged, following their line from right to left, thus: the Thirtyeighth, Thirtieth, Seventh, and Fourth. Each one had detached a battalion to constitute a reserve for the division and also for the corps reserve of the Thirty-eighth French Army Corps to which the American division was still assigned.

General Dickman, whose post of command was at the Château de la Doultre, had placed his troops in depth formation on two positions of which we need only examine the one nearest the enemy. It consisted of numerous trench elements in front of which individual holes for snipers had been dug.

His right covered by our. One Hundred and Twentyfifth Division, his left by our Thirty-ninth Division, General Dickman was in readiness to prevent the enemy at all costs from crossing the Marne. Eastward, and on the southern bank of the river, there still remained some 
American detachments from the Twenty-eighth Division. ${ }^{17}$

This latter had been split up since its arrival from the British front; when it detrained in the region of Gonesse one brigade was assigned to the Thirty-ninth French Division, the other to the One Hundred and Twenty-fifth. General Muir remained with his staff near the commander of the Thirty-ninth French Division. His Fifty-fifth Brigade was mingled with the One Hundred and Twentyfifth Dịvision during the attack of July I 5 th, four American companies being placed in the front line with French troops. The remainder were engaged in organizing and holding a second position.

Such were the conditions under which the American troops withstood the shock on July i 5 th.

General Pétain came to personally inspect the front on which an assault was expected and during the course of his visit he particularly dwelt on the advantage of disposing the troops - artillery as well as infantry - in depth.

17 Order of Battle of the Twenty-eighth Division at the date of August I, 1918 .

Major-General Charles H. Muir, Division Commander

Fifty-fifth Infantry Brigade

Brigadier-General T. W. Darrah

looth Infantry Regiment

Colonel M. D. Brown

IIoth Infantry Regiment

Colonel George M. Kemp
Fifty-sixth Infantry Brigade Brigadier-General Wm. Weigel IIIth Infantry Regiment Colonel Ed. C. Shannon II th Infantry Regiment Colonel Geo. C. Richards

\section{Fifty-third Artillery Brigade}

Brigadier-General Wm. G. Price

${ }_{4}$ Io7th Artillery Regiment

Lieutenant-Colonel A. V. Crookston

108th Artillery Regiment

Lieutenant-Colonel E. St. John Greble, Jr.

Iogth Artillery Regiment

Colonel Asher Miner 


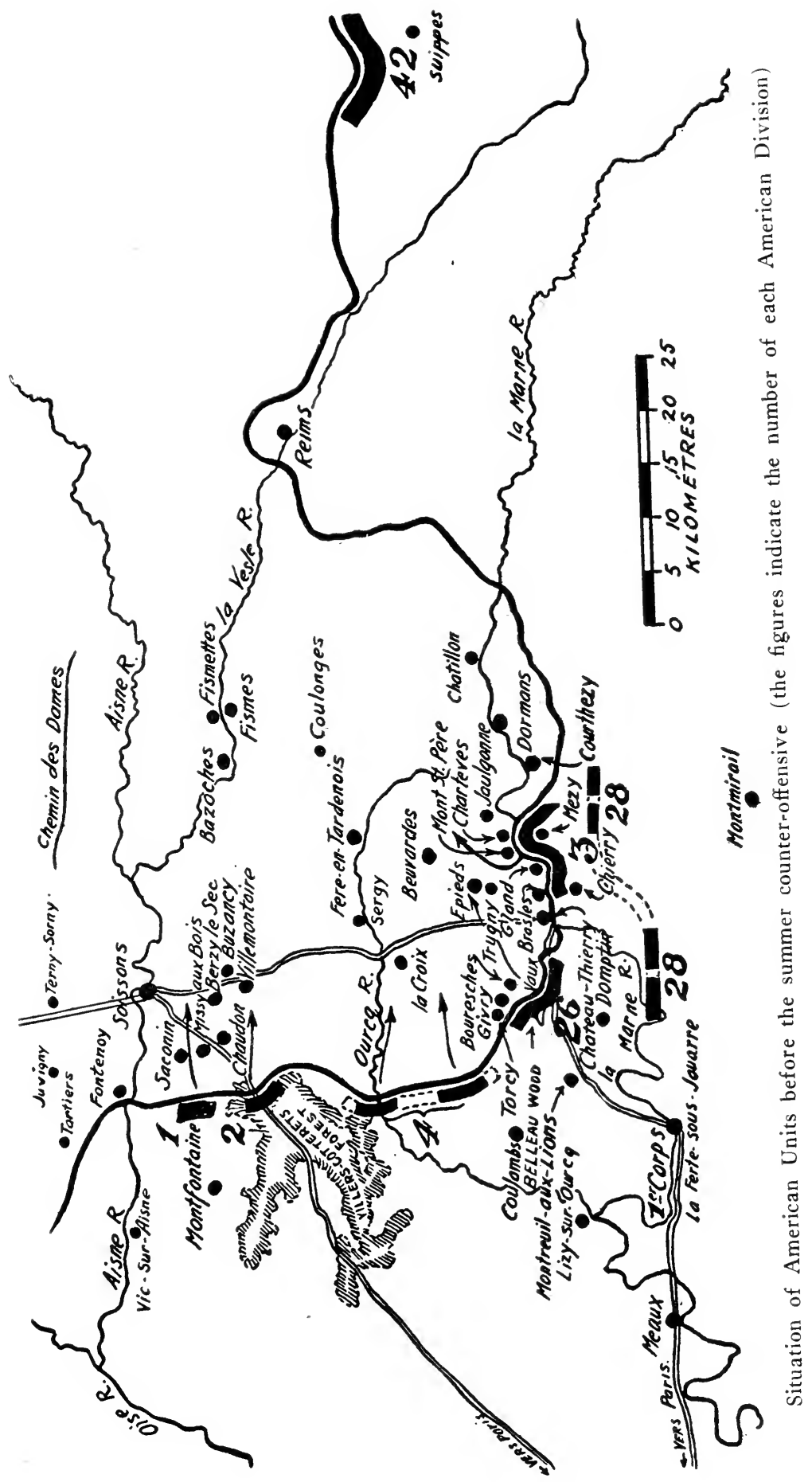



$\mathrm{He}$ recommended also that the combatants should take up their eventual fighting positions before the beginning of the attack. "No maneuvering under fire" said he more than once while discussing the plan with the generals in command of the army groups, armies, and army corps assembled to meet him.

At the front occupied by the Forty-second Division the enemy succeeded in reaching the intermediate position only toward 7 A. M. The three American battalions repulsed a succession of attacks, one battalion of the One Hundred and Sixty-sixth as many as seven. Two companies of the One Hundred and Sixty-seventh joined with two French companies in a brilliant counter-attack on two centers of resistance in the intermediate position which had temporarily fallen into the enemy hands, but which was recaptured. On the whole line the Germans were driven back to the first positions upon which the artillery at once directed a violent fire.

By I I:30 A. M. the Eighty-third Brigade threw forward another battalion on the intermediate position in reënforcement of the One Hundred and Seventieth Division, and the Eighty-fourth Brigade, in turn, detached two companies from the I68th Regiment in support of our Thirteenth Division.

In this glorious affair the Forty-second Division had engaged over five battalions and the American troops received the unqualified congratulations of all the French commanders with whom they had served.

General Gouraud, commanding the Fourth Army, General Naulin commanding the Twenty-first Corps - of which the Forty-second Division formed a part - were much struck with the brilliant behavior of the American troops. 


\section{I64 The American Army in the European Conflict}

As for General Menoher, who was to have taken command of the sectors belonging to the One Hundred and Seventieth and Thirteenth Divisions, as well as that of his own, if the day had gone against us, and if the enemy had succeeded in forcing our troops back upon the third position, he did not have to set his staff to work that day on defensive projects but merely observed, from an advanced post of command on the battle front, the splendid work of his men and contented himself afterward, with extending to them their due meed of praise.

It may be interesting to give below the opinion of one of our own French liaison officers who witnessed the action and who thus sums up his impressions of the American fighting qualities :

"The behavior of the American troops was perfect, and elicited the admiration both of our officers and men; calm under bombardment, supporting with great endurance hardships and privations, tenacious in defense and ardent in counter-attack, they show an evident desire for hand-to-hand combat. These qualities, which I have personally observed, have been commented on by all $\mathrm{my}$ comrades.

"The American artillery behaved splendidly under fire; though the losses were heavy, they had fine opportunities, firing at times directly at such visible objectives as columns of marching infantry or artillery.

"The French commanders in the artillery divisions highly praise the work of the gunners of the Forty-second Division, remarking that the firing was prepared with care and executed with vigor."

In the meantime, on the front of the Third Division, the enemy was subjected also to a severe defeat.

The systems of defense utilized on the Marne were, however, altogether different from those employed by the 
general commanding the Fourth French Army. On the southern bank of the river the success of the day was mainly due apparently to the fire of the individual infantryman, who, posted in front-line trench elements or in separate holes, aimed as coolly as if each man were practicing upon his own rifle range. The automatic pistol and bayonet were used in the course of certain counter-attacks carried out sometimes by companies, sometimes by platoons.

It must be added that the artillery played an effective part in the fight, but this was less striking to the observers than was the infantry action. The guns filled the small ravines and larger valleys with a rain of shells so that the enemy was unable to concentrate any important bodies of men or to press forward toward the river under cover. At no point did he, indeed, succeed in crossing the Marne in force. The attempts made by him to throw bridges to the opposite bank were foiled by our artillery fire, his boats were almost everywhere stopped by the sharpshooters, and where small elements were able to filter into our lines, they were not capable of penetrating far, because they were not reënforced.

On the extreme right, the 38 th Infantry Regiment, in a loop of the Marne near Mezey, where the Surmelin Brook joins the river, made a particularly fine record. Attacked simultaneously on front and flanks by enemy troops, who were afterward found to belong to six different regiments, the 38 th repulsed repeated assaults, threw the enemy back into the Marne, and captured 600 prisoners. The evening following this brilliant action a French officer who had witnessed it wrote as follows: 
"The youthful soldiers of the 38th Regiment did their job finely, showing themselves quite equal to our own best troops. Having received orders to hold on at any cost they got killed only after having accounted for at least three times as many of the enemy and succeeded in maintaining the integrity of their front.

"The rifle fire from the railroad line was directed as accurately as during a maneuver. A certain first sergeant of Company $\mathrm{H}$ verified the sights and pointed out the objectives. We estimate at over a thousand, the German bodies which remained before our lines.

"The grit of the officers, platoon commanders especially, was admirable; one second lieutenant, shot through the chest, remained at his post all day refusing to allow himself to be relieved until he was wounded a second time. One company commander refused to propose his men for any recompense for exceptionally distinguished service, stating that he would then have to recommend all, since each man had fought like a hero. To sum up: These soldiers, if they profit as they surely will by this experience, must count as first-class troops from whom their officers may require anything.

"Colonel McAlexander, commanding the Thirty-eighth Infantry, showed himself to be a remarkable leader, cool-headed and efficient. He is liked and respected by men of whom he, on his side, has every reason to be proud."

In the sector adjoining General Dickman's division the four companies of the Fifty-fifth Brigade who were in the first line had a hard fight and were compelled to fall back on their reserves. In this region the enemy succeeded in crossing the river near St. Aignan and Chapelle-Montodon. Two battalions belonging to the Fifty-fifth Brigade (Twenty-eighth Division) counter-attacked with great vigor.

On July I6th and the days following the enemy attempted to renew the offensive but entirely without success; he had been definitely checked.

Although the American casualties were heavy they wero 
more than compensated by the results achieved. On the evening of the fifteenth the Forty-second Division reported I,200 wounded or gassed and 400 killed.

America had thus contributed 50,000 men in this purely defensive battle which was imposed upon us by the enemy.

Three days later, when we in turn assumed the offensive, I00,000 more Americans were to be found in line, and this number, already imposing, must be again doubled in order to justly estimate America's effort at this epoch of the war.

It is indeed impossible to draw a hard line of demarcation between the attack of the eighteenth of July and the pursuit which was its natural consequence. We must therefore, while relating the part played by the Expeditionary Forces in our first counter-offensive, take into account the share they had later in the exploitation of our success. Consequently, we must add to the I oo, ooo combatants of the First, Second, Fourth, and Twenty-sixth Divisions who were in line on the morning when the battle started the I 25,000 more belonging to the Third, Twentyeighth, Thirty-second, Forty-second, and Seventy-seventh Divisions who came into action during the pursuit of the enemy to the Vesle.

At this critical moment of the war's history America came forward with all her might and we may incidentally mention that the commander-in-chief of the Expeditionary Forces needed no persuasion to make him comprehend the urgency of the vast operations which the Allies were contemplating. But we may more thoroughly appreciate the responsibility which, like a true chief, he personally shouldered when we have made clear the individual situation of each division enumerated above. 
General Pershing was always in favor of an offensive strategy and he was strongly of the opinion that at the present time a powerful counter-offensive was the only course open to the Allies; he had already, on the twentysecond of June, explained his theories to the French high command and the prime minister, and expressed his willingness to take his full share in the task before them.

That his task was not an easy one may be seen as we rapidly pass in review the different American units at the date of July I 7 th; that is to say, on the eve of our great counter-offensive.

The First Division was in good form. It had left the Cantigny-Grivesnes front on July 8th and was perfecting its training and resting in the region of Beauvais. The last days spent in the trenches between Amiens and Montdidier had been comparatively quiet, the calm of the sector only being broken by an occasional exchange of artillery fire. General Summerall was in command of the division, having replaced General Bullard promoted to the Third Corps command.

The Second Division, on the contrary, had been fighting steadily for forty days and had hardly been relieved and concentrated near Montreuil-aux-Lions in order to proceed to the rear when, on the fifteenth, it received orders to remain in the vicinity of its former battle-ground, and to hold itself in readiness for a strong enemy attack. This could not therefore be considered a fresh division. Moreover it had just changed hands, General Harbord, the victor of Belleau Wood, having recently replaced General Bundy, appointed to the command of an army corps.

The Third Division had sustained the fierce onslaught 
of July I 5 th. Although the losses had not been particularly severe, all its units had been engaged in hard fighting, and one regiment, the 38 th, had been badly cut up. The division still remained on the positions it had held in face of the German attacks.

The Fourth Division had been brought down from the British front at the time when it had seemed advisable to increase the density of our troops in the region between Château-Thierry and Paris. It had been at once broken up and divided among the Thirty-ninth and One Hundred and Sixty-fourth French Divisions with the double purpose of receiving practical training and at the same time strengthening these French units. Its infantry had had but few occasions to drill, the sojourn in Flanders having been less than one month; its artillery was still in the training camps.

The Twenty-sixth Division was where we left it on July Ioth, in the Torcy Belleau sector, where it formed the right wing of the First American Corps. Its attitude, as we have seen, although aggressive, had not caused it an abnormal number of casualties, so that we may count General Edwards' division as being still in good fighting condition on July I 7 th.

The Twenty-eighth Division, like the Fourth, passed from the British to the French front and, in greater degree than the latter, had suffered from hasty and numerous displacements. $\mathrm{Up}$ to the moment of going into action, the troops had not been able to become entirely conversant with massed evolutions. Neither before leaving America nor after arriving in Europe had there been much time for maneuvers or fire-practice. The troops who chiefly made up this unit were Pennsylvanian National Guards who had been employed upon the Mexican 


\section{I70 The American Army in the European Conflict}

border and this division still lacked its artillery brigade. Two battalions had been subjected to rather severe losses during the German attack of the Fifteenth, and four of its companies had seen hard fighting during the retirement of the One Hundred and Twenty-fifth Division, in which they had been placed as reënforcement.

Nevertheless the morale was good, and General Muir, "Uncle Charlie" as his men called him, was impatient to see his division once more assembled and engaged in action. After July 15 th, the brigade which had been detailed,with the French One Hundred and Twenty-fifth Division rejoined the Fifty-ninth Brigade and the Twentyeighth Division was once more reconstituted.

The Thirty-second Division was made up of National Guard elements from Michigan and Wisconsin, and came from the Alsace front, where it had been engaged in operating with the French Fortieth Army Corps.

Arriving in France on the twentieth of February, the men had been trained for three months in camps situated in the interior of the country and for the past two months had been enabled to complete their military instruction in a quiet sector. The divisional artillery joined them on the eighteenth of May. ${ }^{18}$

18 Order of Battle of the Thirty-second Division on the first of August, 1918.

Major-General William G. Han, Division Commander

Sixty-third Infantry Brigade

Brigadier-General W. D. Connor

125th Infantry Regiment

Colonel Wm. V. Morrow

126th Infantry Regiment

Colonel Jos. B. Westnedge
Sixth-fourth Infantry Brigade

Brigadier-General Ed. B. Winans

127th Infantry Regiment

Colonel C. R. Langdon

128th Infantry Regiment

Colonel Robert McCoy

Fifty-seventh Artillery Brigade

Brigadier-General LeRoy G. Irwin

IIoth Artillery Regiment

Colonel C. B. McCormick 
The Forty-second Division, which we have just seen resisting all the enemy attacks directed against it up to July I 5 th, was, in spite of heavy losses, in excellent condition and occupied the trenches from which it had repulsed the enemy.

The Seventy-seventh Division had arrived in France on April I $3^{\text {th }}$ and was included with the troops which were sent to the British front for training. On June I6th it was ordered to proceed to Rambervillers and thence, four days later, was placed in the Baccarat sector, where it was joined by the divisional artillery. General Duncan had had therefore the advantage of forty days' trench experience to prepare his men for more active warfare. ${ }^{19}$

Such was the individual condition of each American unit on July I 8 th at which date their participation in our counter-offensive was to begin.

\section{I2oth Artillery Regiment \\ Colonel Carl Penner \\ 147th Artillery Regiment \\ Colonel Boyd Wales}

19 Order of Battle of the Seventy-seventh Division at the date of August 19, 1918 .

Major-General George B. Duncan, Division Commander

I53d Infantry Brigade

Brigadier Gen. E. Wittenmyer 305th Infantry Regiment

Colonel W. R. Smedberg, Jr. 3o6th Infantry Regiment

Colonel G. Vidner 154th Infantry Brigade

Brigadier-General E. M. Johnson 307th Infantry Regiment

Colonel Isaac Irwin 308th Infantry Regiment Colonel N. K. Averill

152d Artillery Brigade

Colonel Manus McCloskey

304th Artillery Regiment

Colonel R. N. Briggs

305th Artillery Regiment

Colonel Fred C. Doyle

3obth Artillery Regiment

Lieutenant-Colonel F. H. Smith 
The general situation may be summed up as follows: The American command had at its disposal to begin and carry on the attack nine divisions. One fresh and that had already given an excellent account of itself in action: The First Division. Two very good divisions which had just been subjected to hard fighting: The Fortysecond and Twenty-sixth. Two which were incomplete, lacking cohesion and training: The Fourth and Twentyeighth. Two still suffering from hard and recent fighting: The Second and Third. Two others which had occupied quiet sectors but had not yet been engaged in active fighting: The Thirty-second and the Seventyseventh.

In order to grasp the individual part taken by each of these units in the great counter-offensive started on July I 8 th and continued well into the month of August, let us describe the battle-front from north to south and from west to east, along that semicircle where the Sixth and Tenth French Armies were drawn up from Fontenoysur-Aisne up to a point above Château-Thierry on the Marne. Such a method seems logical, since it will show us first the decisive action undertaken by the Tenth Army which broke through the German front, then the subordinate action of the Sixth Army, whose movements were regulated upon those of General Mangin's forces.

The rôle of the Tenth Army was to rupture the enemy lines between the Aisne and the Ourcq, and to push ahead in the direction of Fère-en-Tardenois, while the Sixth Army conforming to this movement should advance its left wing.

General Mangin had at his disposal the First and Second American Divisions, which he assigned to the 
Twentieth French Corps, whose commander, General Berdoulat, organized his front from left to right as follows: The First American Division; the Moroccan Division; the Second American Division.

General Pershing had requested that the American divisions might be maintained side by side. He would even have preferred to group them into one purely American army corps, and in view of this junction he had ordered General Bullard to transfer his headquarters from Remiremont and proceed to the scene of the active operations which were about to begin.

But the commander of the Third Corps ${ }^{20}$ was only able to arrive in the zone of concentration on the sixteenth of July and with a greatly reduced staff; furthermore, General Pershing's desire could not be carried out on account of the rapidity of events. General Bullard therefore acted as assistant to General Berdoulat and was placed in administrative control of the First and Second American Divisions.

It was on the sixteenth of July that these two units then in process of transportation got their orders from the Twentieth Corps. ${ }^{21}$ The First Division, coming from the Froissy-Beauvais region, was being concentrated behind the French line, the infantry having been transported in motor trucks. The Second Division, which

${ }^{20}$ Composition of the Third American Corps Staff at the date of July $16,1918$.

Major-General Robert L. Bullard, Corps Commander

Brigadier-General A. W. Bjoranstad.............. Chief of Staff Lieutenant-Colonel Lorenzo D. Gasser............. Chief of G-r

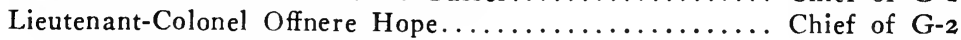
Lieutenant-Colonel Francis W. Clark............................ ${ }^{21}$ It was not until July 15 th at 2 P. M. that the general commanding the Third Corps learned of the offensive between the Aisne and the Ourcq which was about to be started. 


\section{I74 The American Army in the European Conflict}

had been brought from Montreuil-aux-Lions, the mounted troops by road, the dismounted troops on trucks, was only assembled on the dark and rainy night of the seventeenth to the eighteenth of July. By a curious and picturesque coincidence of war time, these trucks were driven by Anamite soldiers. Thus the ancient civilization of Asia was conducting young America to the battlefield.

The placing of the attacking waves was effectuated with great difficulty. Several battalions belonging to the marine brigade were forced to take the "double quick" for a mile or so in order to get ahead of the blocks of ammunition trucks which encumbered the paths through the forest. On the evening of the seventeenth the crossroads of Nemours, in the Villers Cotterets Forest, afforded a curious spectacle. On the torn-up roadway three files of wagons, caissons, ammunition trucks, lorries, and tanks moved slowly and heavily forward. The American infantrymen in their yellowish tunics, much darker in color when the troops belonged to the marine brigade, clambered in Indian file along the embanked ditches which border the roadway or pushed through the undergrowth of the adjacent forest. At every crossroad, serious blocks occurred in this multifarious traffic testing the patience and address of the French gendarmes and the American military police.

As for the artilleryman of the American forces he displayed an initiative quite equal to that of his infantry comrade. While the latter pressed on through the woodland bypaths, the gunners pushed their cannon forward across country, reconnoitered the positions prepared the previous day and got ready to open fire according to maps, plans, and calculations made on paper, strict orders 
having been issued that not a shot must be fired before the general attack.

Nevertheless, in spite of the fact that no ranging had been possible, when the hour of the assault came the artillery was ready with a rolling barrage, thereby assuring the early success of the day. In fact all the difficulties incident to the taking up of these positions were quite forgotten when, at 4.35 A. M., July i 8 th, the entire front of the Tenth Army began to push forward.

The First Division, to which were added a French $75 \mathrm{~mm}$. regiment and forty-eight Schneider tanks, now began its impressive advance. The four regiments each had certain elements in the first line and were echeloned in depth.

The Second Division also was reënforced by a $75 \mathrm{~mm}$. regiment and had fifty-four St. Chamond tanks. The brigades were placed one behind the other and took the field in splendid order. A few units which had not been able to collect their machine-gun sections, nowise embarrassed by the lack of their own weapons, threw themselves upon those of the enemy and fought through the entire day with the material they had so dashingly conquered!

The intention of the Twentieth Corps commander had been to advance in three successive bounds from the line of departure, situated on the fringe of the Villers Cotterets Forest to a line running approximately from north to south and passing through the villages of $\mathrm{Sa}$ conin, Missy-aux-bois, and Chaudun. Thus the SoissonsParis highroad would have fallen into our hands, while that of Soissons-Château-Thierry would have been seriously threatened.

At 7.45 A. M., the two American divisions on the right 


\section{I76 The American Army in the European Conflict}

and left wing, with the Moroccan division occupying the center, had attained the second objective, each division covering a front of a mile and a quarter.

In the course of the day, as the offensive went on, the Americans succeeded in everywhere keeping their line level with that of our valiant Colonial troops when they did not get beyond them. At an early hour they were ready to carry the guns forward in support of the infantry advance which now bit deep into the enemy line.

In the evening, General Summerall's soldiers had reachẹd the Soissons-Château-Thierry road and General Harbord's men were on the western outskirts of Villemontoire and Tigny.

On the following days the attack was resumed along the entire front of the Tenth Army and the American divisions once more distinguished themselves by the ardor of their fighting spirit.

The Second Division in its turn reached the SoissonsChâteau-Thierry road southeast of Villemontoire.

The First Division, which was obliged to slacken speed so as to enable the neighboring division on the left to come up, then seized Berzy-le-sec, the Buzancy Mill, and reached the edge of the village of Chierry.

It is estimated that 10,000 men and officers were killed, wounded, or evacuated. But in spite of the fact that the losses were numerous this fight may be considered one of the most brilliant of the entire war, especially when we compare the casualties with the trophies wrested from the enemy.

On July 2oth, when the Second Division left the field, and on the 24 th, when the First Division was, in its turn, relieved, the latter carried with it 3,300 prisoners and 
7 I cannons: the former 2,950 prisoners and 75 cannons.

The American soldier had fully justified the confidence of his commander-in-chief; the infantry had been splendid in attack, obstinate in its sustained effort, and excellent in marksmanship. But the passage of the lines had been difficult and arduous, the long pauses upon ground freshly conquered and subjected to sharp enemy fire had been trying to these inexperienced troops, more especially to the Second Division, already severely tested by a long night march before entering into action. To sum up, each new experience proved that the American army possessed increasing qualities of audacity and skill; its aptitude for attack was more and more evident.

The Third Corps was withdrawn and sent to rest at the Château de Vallière near Morte Fontaine.

The First and Second Divisions, now once more rejoined by their respective artilleries - which had been obliged to remain some time on the battle-field after the relief of the infantry - were regrouped in the regions respectively of Dommartin-en-Goele and of Nanteuil-leHaudouin.

Further south, on the front of the Sixth Army, three regiments of the Fourth Division took part in the general attack with the same fortune which attended their comrades of the Thirty-ninth and One Hundred and Sixtyfourth French Divisions. The $47_{\text {th }}$ Regiment was held in reserve on a second position.

On the front assigned to our Thirty-ninth Division, the 39th Infantry Regiment shared in the taking of Norroy on the eighteenth and continued to advance, attaining on the nineteenth the three successive objectives assigned 


\section{I78 The American Army in the European Conflict}

to it. It was relieved on the same night by French troops.

Along the front of the One Hundred and Sixtyfourth Division, the entire Eighth Brigade, although split into separate groups, took part in the offensive.

On the eighteenth the Franco-Americans captured Hautevesnes at five A. M., Courchamps at eleven; later, according to General Gaucher's report, they reached Chevillon "with splendid dash." On the nineteenth the advance was continued, and Priey first, then the farm La Grenouillières were taken by the combined forces. The Americans were relieved on the night of the twentysecond after having participated in the storming of Sommelans, Petret, and Bois de Bonnes.

On the twenty-fourth the Fourth Division was regrouped behind the fighting line.

This division was not, however, to remain long at rest. It was obliged the same day to detach the $47^{\text {th }}$ Regiment to mop up the Chatelet Wood. The 39th Regiment, which occupied a position between Lacroix and Joncourt, was also detached from this division.

The next day another regiment, the $58 \mathrm{th}$, was given to support a French corps, and these three regiments did not rejoin their division until July 29th. From this date on the Fourth Division will be found solely with the First American Corps in whose ranks it figures after August 3 d. ${ }^{22}$

Southward, near the apex of our offensive, we find the First American Corps, having on its left the One

22 The Fourth Division before relieving the Forty-second Division, detached several battalions in support of this unit. Thus it was that troops of the Forty-seventh were mixed with those of the Forty-second Division during the severe attack on Sergy. 
Hundred and Sixty-seventh French Division, and on its right the Twenty-Sixth American Division. ${ }^{23}$ This corps took part in the attack of July i 8 th. While the French were engaged before Torcy the Americans seized upon the village of Givry, Belleau, and the station of Bouresches.

South of Monthiers, the enemy had installed a great number of machine gun nests which made our progress most difficult and during the two days immediately following the first successful operations the advance was quite limited, but on the twenty-first the whole front of the American Army Corps went forward some three miles and a half, attaining the region of Epieds-Trugny.

On the twenty-fourth a new forward bound of three miles carried General Liggett's line up to Beuvardes; from the twenty-fourth to the twenty-sixth the advance was slow but steady.

The Forty-second Division, relieving the Twenty-sixth, extended its front in order to take in that of the One Hundred and Sixty-seventh French Division. From this time until the Vesle was reached, the First American Corps had but one division in line.

On July 28 th still another three miles' advance was recorded in the course of which the Ourcq was crossed on a two mile front and the farm of Meurcy and the village of Sergy taken. After debouching from this river a strong enemy resistance was encountered; the Americans ran up against a veritable mass of automatic rifles. A strenuous fight ensued, during which the village of Sergy many times changed hands.

In the yellow wheat-fields which covered the slopes

${ }^{23}$ On the twenty-second, the Fifty-sixth Brigade of the Twenty-eighth Division relieved the right brigade of the $T$ wenty-sixth Division. 


\section{I80 The American Army in the European Conflict}

adjacent to the Meurcy farm, along the heights above Fère-en-Tardenois, bordering the little mud road between Sergy and "the Poplars" and on the hills extending from these trees down to Cièrges, General Liggett, on visiting the scene of action, found the bodies of his own men not twenty yards from the German lines; the khaki uniforms were stretched beside the greenish tunic of the emperor's troops up to the very entrenchments of the enemy machine guns where these men had met in a death grapple.

On August $2 \mathrm{~d}$ the advance was again resumed. On the third, when the Fourth Division relieved the Fortysecond, the American troops passed almost without resistance through Dole Forest and the Vesle was reached. At the same time the Franco-British contingents of the Tenth Army had attained the heights of Grand Rozoy, thus facilitating the American advance.

The river was crossed on August 6th. The First Corps Headquarters saw the Fourth Division relieved by the Seventy-seventh and, on August I 3 th were placed in reserve at La Ferté-sous-Jouarre.

During twenty days of unremitting pursuit, an advance of twenty miles had been achieved by this army corps on an average front of two miles and a half, 674 prisoners were taken from twelve different German divisions. Seven cannons and 230 machine guns were counted.

Still further south and slightly to the east we find the Thirty-eighth French Corps posted along the Marne with the Thirty-ninth French and the Third American Divisions in line, the Twenty-eighth Division being held in reserve.

On this section of the front no unit was engaged in 
the action of July I 8th. Not until the night of the twentieth to the twenty-first, when the enemy yielded to the pressure coming from the west, did General Mondesir push his troops forward.

Then in close pursuit of the enemy's rear guards the Third Division crossed the Marne and took Brasles, Gland, Mont-St. Père, Chartèves, and Jaulgonne. The vigorous pursuit was only interrupted when prolonged machine gun resistance was met with.

In the course of this northward march, a brigade of the Twenty-eighth Division relieved the Thirty-ninth French, then in its turn the Thirty-second American Division replaced the Third Division, which, severely tried, went to rest and recuperate near the Marne.

The entrance of the Thirty-second Division (July 27th) increased the activity of the sector and hastened progression.

On August Ist, the Thirty-eighth French Corps, consisting now of only American units advanced toward the Vesle with the Thirty-second Division in line, the Twentyeighth in support, ${ }^{24}$ and the Third in reserve.

Under such circumstances it became natural to confide the direction of operations to an American officer and accordingly General Bullard assumed command. On August 4th, when the line reached up to Fismes, the headquarters of the Third American Corps was established at Coulanges.

After this American Army Corps had lined up on the Vesle, it extended out rightward relieving the Fourth French Division with part of the Twenty-eighth.

On August 6th the Thirty-second Division encountered serious resistance when attempting to debouch north of ${ }^{24}$ This division had a few elements in the first line. 
the Vesle. It was withdrawn after severe fighting and relieved by the $T$ wenty-eighth Division which was now completely deployed.

From this time up to their ultimate departure from the Vesle region a monotonous period of stabilization, followed, interrupted occasionally by sharp attacks whose object was to establish solid bridgeheads on the northern bank. These operations were long, laborious, and costly. The enemy launched a succession of fierce counter-attacks and General Bullard had difficulty in maintaining his advanced posts on the northern side of the river.

On August 13 th when the Seventy-seventh Division came into line and the First American Corps was withdrawn, the Third Corps extended leftward in order to take into its sector this new American unit.

Supported on the right and left by French troops and having the Seventy-seventh and Twenty-eighth Divisions in line and the Thirty-second in reserve, General Bullard endeavored to enlarge his bridgeheads on the Vesle and to gain a footing on the plateau between this river and the Aisne.

The artillery duel was particularly fierce at this point; patrols advanced with difficulty and certain daring raids were made without any appreciable result being achieved. Bazoches and Fismettes changed hands many times.

It now became necessary either to await, in depth formation, for the enemy to exhibit any sign of giving ground or to secure sufficient artillery reënforcements to enable a strong and methodical attack on the enemy's heavily garrisoned position.

The formation adopted by General Bullard was practically: Four battalions at the advanced posts; eight battalions on the positions of resistance; twelve battalions back of the barrage line. 
On September seventh the Twenty-eighth Division was relieved and, on the following day, the Third Corps was withdrawn from this front and at precisely the same moment the enemy began to loosen his grasp of the heights between the Aisne and the Vesle. An advance was started especially toward Bazoches. The successful attacks which were taking place at this time on the FrancoBritish front near the Oise had contributed to ameliorate conditions on the Vesle, and General Bullard upon leaving his position turned over to the Sixteenth French Corps a greatly improved situation. We must not omit to mention that during August the Third Corps had received two regiments of its own artillery.

While the Third Corps was engaged in these operations the Thirty-second Division which had been withdrawn from the front on August $7^{\text {th }}$ in order to be placed in rest positions along the Ourcq, suddenly received marching orders on the night of the twenty-second and twenty-third of August and was transported by truck to Vic-sur-Aisne, where it was placed at the disposal of the Tenth French Army.

General Mangin at once sent it into action on August 27 th, beyond Tartiers and with Juvigny as objective.

The Sixty-third Brigade, which was deployed in the first line, advanced boldly to the vicinity of Juvigny, capturing more than 500 prisoners. However, in spite of several attempts, it was found impossible to take the village, and at this point the Fifty-fourth Brigade relieved the Sixty-third and, taking advantage of an artillery preparation which had continued for several days, seized Juvigny, where they found 700 unwounded prisoners. The advance was resumed on the day following. 


\section{I84 The American Army in the European Conflict}

This same brigade, reënforced by one battalion and a machine-gun company (from the $125^{\text {th }}$ Regiment and lent by the Sixty-third Brigade), succeeded in gaining ground toward Terny-Sorny.

The next day they continued to press the enemy hard and attained the road from Soissons to Coucy-le-Château in the immediate neighborhood of Terny-Sorny. The machine-gun company of the $125^{\text {th }}$ Regiment captured a German machine-gun company on ground east of Juvigny and also seized a battery of $105 \mathrm{~mm}$. abandoned by the 'enemy alongside the highroad.

The rapid progression of the Thirty-second Division was continued by the Moroccans of our Second Division, who went through the Americans and followed up their success.

For several days longer the Thirty-second Division remained in support of our colonial troops; then, after having been cited by General Mangin in his Tenth Army orders, this division was, like other American troops, withdrawn from the Soissons region.

With the departure of the Third Army Corps from the Vesle sector and that of the Thirty-second Division from the Soissons region our narrative of the summer counter-offensive of 19 I 8 is naturally brought to a close.

We cannot, however, terminate our recital of the American share in the July counter-offensive without saying one more word in regard to the masterly manner in which General Pershing handled his large and growing formations, and in calling attention once more to his firm and decided policy in these matters.

Each time that he saw an occasion of incorporating two separate brigades into one fighting division he did so. 
Whenever it was possible to place two American divisions side by side he at once arranged that they should be formed into an American Army Corps.

His activity in this direction might specially have been observed during the first days of August, when, at La Ferte sous Jouarre, he himself supervised the organization of his contingents into the First American Army.

From this time on the American forces were week by week augmenting in number, new units were daily being disembarked in our ports and sent into instruction camps. The lines of communication, so difficult in the beginning to establish, were now rapidly being perfected and the moment was evidently near when military action on a vaster scale than that hitherto contemplated might be looked forward to.

The keen foresight and military intuition of General Pershing were not at fault in his rapid estimation of the new conditions and the modifications brought about by recent events. He realized at once that America was called upon to center her energies in a new theater of war and that operations more difficult and more important than those which he had had in contemplation upon the Vesle front were about to develop in quite another sector.

These considerations led him temporarily to abandon his project for the building up of an essentially American army on the Vesle and turn his attention to centralizing elsewhere command of the troops available for combat.

In order to strike a decisive blow at a vital spot of the German line it was necessary to group together the American fighting divisions which had so gallantly won their laurels in Champagne.

Their presence was now required elsewhere no less than the personal direction of the commander-in-chief. 


\section{CHAPTER VI}

ORGANIZATION OF THE MAIN SERVICES OF THE EXPEDITIONARY FORCES - CHIEF OF ARTILLERY - TANK CORPS - CHIEF ENGINEER - AIR SERVICE - SIGNAL CORPS - MEDICAL DEPARTMENT - QUARTERMASTER - ORDNANCE - CHEMICAL WARFARE INSPECTOR GENERAL - JUDGE-ADVOCATE

Practically all the heads of the main services of the American Expeditionary Forces were for a few months at least stationed at the Chaumont headquarters. In making this decision and assembling together in the zone of armies the administrative departments and sections of his general staff, the commander-in-chief had a very important object in view. It was his intention, in so doing, to give to the organizations which were to handle his army a unity both of views and of methods which could only be acquired through daily work undertaken in common. He desired to see the chiefs of all the main services of supply fully conversant with the requirements of the field combat troops and with the demands of the General Staff. On the other hand it was his wish that all the staff officers selected by him - and who for the most part were new to their work - should be thoroughly acquainted with the details of the operations and output possibilities of the services of the rear.

$\mathrm{He}$ foresaw the day when it would be necessary to separate them; in fact, he was quite decided not to allow his headquarters to become top-heavy. He would deI86 
cide when the time came, according to circumstances, whether it would be better to move his staff nearer to the front or rather maintain it at Chaumont and transfer the administrative departments to the rear.

On February 16, 1918, his decision was taken. The line of communication, the headquarters of which was established at Tours - was thoroughly reorganized and assumed the title of "Services of Supply" shortened to S. O. S., a name practically equivalent to our "Direction Générale de L'Arrière" or rear service. This was divided into eleven sections or departments: Quartermaster, Medical Corps, Engineer Department, Ordnance, Signal Corps, Air Service, Chemical Warfare, Transportation Department, Motor Transport Service, Provost Marshal, ${ }^{1}$ General Purchasing Board.

General Pershing maintained at his headquarters the departments of the Inspector General, of Artillery, of Tanks, and finally that of the Judge-Advocate.

The departments established at Tours were to designate the necessary number of officers who were to represent them at Chaumont in order to remain in touch with the heads of the sections of the General Staff.

Thus the number of officers stationed at headquarters was considerably diminished and the staff of the commander-in-chief, while maintaining a general supervision and control over the services of supply, was placed in a position where it could turn most of its attention to strictly military operations.

The General Staff was thus freed from the petty annoyances, delays, and discussions which form a necessary part of business routine when the directive departments are placed in too close proximity to the executive. The

${ }^{1}$ Later transferred to general headquarters. 


\section{88 The American Army in the European Conflict}

latter were now grouped together under a single head the general commanding the S. O. S.- who remained alone responsible to the commander-in-chief for the working of the services of the rear. According to the excellent expression of the American regulations: The armies in the field found themselves freed from every preoccupation other than that of defeating the enemy.

If we were to imagine that our direction of the rear services in France were to be transferred to the Ministry of War in Paris instead of operating at headquarters, and afterward, that the Ministry of War thus supplemented should be placed under the direct control of the commander-in-chief of the French armies we would evoke an organization similar to that created by General Pershing.

Before beginning to study the methods and working of what we shall denominate American " services" it is very important to observe that this designation covers a number of organizations whose ways and principles are very widely divergent.

Some of these possess a considerable range including the disbursement of funds specifically appropriated for their requirements. Not only do they organize and instruct their own personnel, but they are also authorized to procure for themselves, either by purchase in Europe or through requisition in the United States, the divers materials needed in order to carry on their activities. Others, on the contrary, confine themselves to the training and employment of their personnel, and the necessary material required by them is furnished by different departments; from the French point of view they are "arms" rather than "services." 
The American artillery belongs to this latter category.

Of all the constituent elements of which modern armies are made up the artillery is the most complex as to organization, training, and equipment.

Three questions call for the closest attention on the part of its chiefs: Personnel, horses, and material. In the American Army the responsibility for these two latter actually rests on the quartermaster and on the chief of ordnance. But although the troops themselves which constituted the artillery of the Expeditionary Forces, were drawn from the United States, by far the greater part of its horses, guns, and munitions were purchased in France and in Great Britain. It was therefore necessary, once the troops were disembarked, to undertake the formation of units. This was the first and most important duty of the service of artillery.

The chief of this service was entirely responsible for the training and organization of all the units up to the time that they were assigned to the division, army corps, or armies to which they normally belonged. But they were only turned over to these when the batteries, battalions, and regiments had acquired a degree of instruction that enabled them to give a good account of themselves on the battle-field. It was therefore the duty of the chief of artillery to establish all the camps, firing ranges, and schools that were necessary for the training of officers and men. Finally, for all matters pertaining to artillery he acted in the capacity of technical adviser to the commander-in-chief.

Thirty-one divisional brigades of artillery, seven regiments of army corps artillery, giving a total of some 7,500 officers and 197,000 men, have thus been trained and made ready for combat under the direction of the 
chief of artillery of the American Expeditionary Forces.

These services were divided into four sections: Field artillery; heavy artillery; material; information and intelligence.

The first section was a very important one. It controlled the training of all the field artillery including not only the batteries of 75 's, but also the regiments of I $55 \mathrm{~mm}$. howitzers which formed part of the divisional artilleries.

The principles of organization and the general program of training had been laid down by General March, and when he left France for the United States upon his appointment as chief of the General Staff, the instructions left by him were followed without any modifications worth mentioning.

The field artillery section was in charge of the technical inspection of all units engaged in active operations and was to follow very closely all the evolutions of artillery tactics. It also supervised the work of the school for tractor driving that had been established at Le Blanc, with a view to the motorization of the regiments of I $55 \mathrm{~mm}$. howitzers.

The duties of the second section concerning the units of heavy artillery ( $55 \mathrm{~mm}$. guns and heavier calibers) and also trench artillery were the same as those of the field artillery section. The section of material had control of all studies and work pertaining to the upkeep and proper adaptation of the material at the front, to the equipment of those units which were in training camps or actually engaged in combat, to the perfecting of the existing material and the creation of new types, to the arranging and equipment of the organization centers, and finally to the establishment of schools. This service 
also directed the activities of the ordnance as far as manufacturing artillery material was concerned.

The section of information centralized all intelligence concerning allied or enemy artillery. It spread all necessary information by means of a bulletin which it published and widely distributed among all the artillery organizations.

As soon as a unit of field or heavy artillery was ready for combat, it was removed from the direct control of the chief of artillery. Thus certain regiments and brigades were placed at the disposition of the general commanding the artillery of the First Army at a time when that army had not yet been organized.

This was also the case for the railroad artillery in training at Mailly which was turned over to General McGlachlin, commanding the artillery of the same First Army long before the Saint-Mihiel operation was actually begun.

General Pershing considered this system advantageous in that it gave the artillery command of the First Army a longer time in which to prepare for its important functions.

The American railroad artillery, placed at first under the orders of General Coe, then under those of General Chamberlaine, comprised on October Ist, igi 8, two brigades, of which one only had received its material, and a detachment of naval gunners.

The brigade that was fully equipped, the Thirtieth, possessed sixteen $240 \mathrm{~mm}$. (9.4-inch) guns, thirty-two of I $94 \mathrm{~mm}$. (7.6-inch), twelve of $320 \mathrm{~mm}$. ( I $2: 6$-inch), two of $340 \mathrm{~mm}$. ( $33: 4-$ inch), four of $400 \mathrm{~mm}$. guns ( I6inch).

All these guns and howitzers were of French model and 


\section{The American Army in the European Confict}

for the most part were utilized in the two great American offensives of the fall of I9I8. The detachment of naval gunners assigned to the railroad artillery was under command of Rear-Admiral Plunkett and manned five American fourteen-inch guns.

The American artillery trained and commanded by such chiefs as Generals Hinds, McGlachlin, and Lassiter always comported itself in a manner deserving all praise and earned the admiration of those French artillerymen who were privileged to find themselves by its side in combat. .

The quickness of its evolutions, taking up battery positions, and changes of firing objectives, the care and vigor shown in the preparation and execution of fire, gave it at once a marked superiority over the German artillery, and this the enemy himself was compelled to acknowledge on several occasions. A German document which is at present before our eyes states that their troops feared American artillery on account of "the power and accuracy of its fire."

It should be incidentally mentioned that for a long time before America came into the war modern methods of artillery fire had been thoroughly studied and widely discussed in the military circles of the United States. A new theory had been developed which rejected the system of brackets in range firing, considering that this was a method which involved a great expenditure both of time and ammunition. This new school warmly advocated the immediate attempt at a direct hit. They considered that the solution of this problem was to be found in the careful establishment of preliminary calculations, as well as in the perfecting of sighting apparatus which, according to their ideas, should be made so as to indicate the amount 
of distance by which the hit had missed the target, and not, according to prevailing systems, merely whether the shot had been too long, too short, too much to the right, or to the left.

Possessing as it did a nucleus of officers having a very great technical ability, provided with observers who not only on the ground, but also in the air, gave proof of an absolute contempt for danger, manned by crews who were full of aggressive ardor, confidence in their material, and lavish in expenditure of ammunition, the American artillery never ceased for one instant to make its presence felt in the most brilliant manner upon the battle-field, where it proved itself a most redoubtable adversary for the German batteries.

The tank service created in France during the present war did not, of course, exist in the American Army.

Immediately upon the entry of the United States into the war the Washington authorities took up the question of organizing this new branch of the service, the importance of which appeared to be rapidly increasing.

Prior to the arrival of the American Expeditionary Forces, the American military mission in Paris had, by direction of the chief of the War College, investigated and submitted a report under date of May 2I, I9I7, giving the latest British and French technical and tactical ideas on the use of tanks.

The French, at that time, had only two types of tanks; the St. Chamond and the Schneider. Neither were tanks in the sense of later development. They were, more properly speaking, artillery carriers. They had numerous defects, suffered from frequent hitches in the engine, progress over rough ground was difficult, their vulner- 


\section{I94 The American Army in the European Conflict}

ability was great, and their field of vision narrow. At this time the French had under construction a light tank of the Renault type designed for employment in very close contact with the infantry.

The British, on the contrary, preferred the heavy tank to be used far in advance of the first line of skirmishers.

Upon his arrival in France General Pershing made very thorough investigations into this subject. The result of his study led to the conclusion that the American Expeditionary Forces should be equipped with two types of tank, a heavy type and a light one. His representative at the Inter-Allied Committee was instructed accordingly. Negotiations undertaken with the British Government had a satisfactory result as far as heavy tanks were concerned. Choice was definitely made of a powerful model called "Mark 8," which was neither more nor less than a Renault tank greatly augmented in size and provided with a Liberty engine. The American Government approved of this decision, and decided that I,500 Liberty engines were to be reserved for a like number of tanks, the latter to be constructed in Europe by October I, I 9 I 8.

In the meanwhile, negotiations were undertaken with the Renault firm with a view to manufacturing their light tank in the United States, as it appeared to possess excellent fighting qualities. On December 23, I9I7, Colonel Rockenbach, since promoted to the rank of brigadier-general, arrived at general headquarters and was detailed as chief of the tank corps.

As far as heavy machines were concerned, the only course open to him was to approve what had been done previous to his arrival. It was evident that a long period must necessarily elapse before the time when the United States would be in a position to manufacture such engines 
and their equipment. He therefore decided to limit orders to the manufacture of the Anglo-American model, "Liberty No. 8."

As to the light tanks the French Renault model was definitely adopted with some minor improvements: addition of a bulkhead separating the gun room from the engine, so that the crew would not run the danger of being burned, and of a self-starter; the machine was to have its gasoline tank double-cased with a felt interlining one inch thick so that, if penetrated by a bullet, there would be no leakage of gas. It was also to be equipped with an interchangeable mount, so that the same tank could carry either a machine gun or a $37 \mathrm{~mm}$. gun ( 1.5 inch).

The organization of units, as far as personnel was concerned, was based on the idea that war could be won only by taking the offensive for prolonged periods; therefore the tanks must have an organization providing reliefs so that the crews who fought one day would not be required to go into action the next; it was therefore necessary, back of the companies, battalions, and brigades, to have replacement units able to step in as substitutes for exhausted or disabled men.

A revised project for a combat tank corps was approved by the general headquarters on February i 8 th, and, by the War Department on the twenty-first of March. It provided for the necessary headquarters 5 battalions of heavy ${ }^{2}$ and 20 of light ${ }^{3}$ tanks, repair, salvage, and depot organizations, training centers, and replacement companies in France equal to twenty-five per

2 The heavy battalion consisted of 69 combat and 4 signal tanks, giving a total of 146 6-pounder guns and 584 Hotchkiss machine guns.

3 The light battalion was composed of 72 combat and 4 signal tanks, having an armament of $3037 \mathrm{~mm}$. guns and $4^{2}$ Hotchkiss machine guns. 


\section{The American Army in the European Conflict}

cent. of the combat forces. Twenty-five per cent. more were to be kept in reserve in the United States.

By July, the importance of tanks was becoming ever greater and an increase of five heavy battalions was authorized, these to be organized with already projected battalions into ten brigades each consisting of one heavy battalion, two light battalions, one repair and salvage company. All tank corps troops were classed as headquarter troops and were to be allotted to armies according to the nature of the ground on which operations were to take place. Allotment for an army was normally: Army tank corps headquarters, five brigades, one heavy artillery ordnance mobile repair shop.

Each group of the above composition was to have at its disposal one training center. This organization was to give a total of $75^{\circ}$ heavy fighting tanks, I, 450 light fighting tanks with a reserve of fifteen per cent a month.

Such were the plans; circumstances, as we shall see, considerably modified their execution.

In June, I9 I 8, the Inter-Allied Tank Committee which periodically met at Versailles, had reached the conclusion that it would be impossible to count upon the importation from the United States of any considerable number of American-made tanks before I9I9. The French then undertook to equip two American battalions with light tanks, the British agreed to equip the battalion that had completed its training in England with heavy tanks, provided that it should be attached, for operation, to the British armies in France.

These three battalions were the only American tank units to appear on the battle-field prior to the close of hostilities.

The Three Hundred and Fourth Brigade, consisting 
of the two light Renault battalions, took a glorious share in the Saint-Mihiel battle and in the operations between the Meuse and the Argonne.

The Three Hundred and First Battalion, equipped with British tanks, was engaged in constant fighting on the British front. From September 29th to October $23 \mathrm{~d}$ it took part in many attacks and behaved in a way to deserve the unqualified praise of the British high command.

On the day of the armistice, the tank corps of the Expeditionary Forces disposed of 755 officers and 9,222 non-commissioned officers and men, all of whom were thoroughly trained. The material on hand consisted altogether of 36 British heavy tanks of three different models, and of 208 French tanks, all of the Renault type. The first American-made machines arrived in France only in the last days of November.

Thus, the end of hostilities prevented the tank corps from giving full measure of its value. Nevertheless, the personnel had already had sufficient time to impress both friends and enemies with their intrepid conduct on the battle-field and their technical skill in handling such complicated machines.

The duties of the engineer service of the American Expeditionary Forces ${ }^{4}$ as determined by General Order No. 3I, dated February I6, I9I8, and, as they werewith a few minor changes - to remain up to the end of the war, were as follows: Mines, field fortifications, surveys and maps not otherwise assigned, searchlights, engineer supplies, engineer depots, storehouses, and shops, water supply and installation, supply of electric light and power, supply of personnel and material for gas, etc. (this

4 Brigadier-General Taylor was at the head of this service. 


\section{I98 The American Army in the European Conflict}

service was later taken over by the chemical warfare service), construction and repair (except that assigned to the transportation department), technical inspection of engineer organizations, sewage disposal plant and operations, camouflage.

During active operations the engineer service was divided into the department of construction and forestry, the department of military engineering and engineering supplies, the department of light railways and roads.

The first of these took charge of all construction of ports, depots, camps, hospitals, railroads, production of lumber for construction, and fuel.

Under the able direction of General E. Jadwin, one of the builders of the Panama Canal, the engineer corps executed, both in England and France, innumerable works of which the most important were undertaken at Montoir, St. Sulpice, Gièvres, described in the chapter dealing with the Line of Communications.

At the date of the armistice American engineers were at work on some four hundred projects and emploved I 50,000 men, consisting of I00,000 Americans, 33,000 civilians of divers nationalities, I 7,000 German prisoners.

Work in the ports included the construction of docks with the warehouses thereon, railroad connections, and lighters.

Storage comprised supply depots in the intermediate and advanced sections, special ammunition and aviation depots, coal storage yards, gasoline and oil stations, motor transport parks, remount depots, veterinary hospitals, refrigerating plants, bakeries, and salvage depots.

In the provision of shelter for troops 16,000 barracks were erected capable of housing 742,000 men. When the armistice was signed, space in hospitals had been pro- 
vided for 280,000 beds or 14.02 per cent. of the entire strength of the Expeditionary Forces.

Lumber production commenced in December, 19 I 7 , and was increased until in October, I9 I8, eighty-one sawmills were in operation. The total production to May I, I919, amounted to 217,884,337 feet board measure of lumber, 3,955,678 railroad ties, 2,954,563 piling and round products, and 43 I, I 47 cords of fuel wood.

Road work in the S. O. S. except in the advance section, was executed by the department of construction and forestry. Previous to the armistice, over three hundred miles of roads were repaired and ninety miles of new roads constructed.

The light railway operations of American Expeditionary Forces began in August, I9 I $7,{ }^{5}$ when the 12 th and I $4_{\text {th }}$ Regiments of engineers, immediately on their arrival in France, were sent to take over the maintenance operations of certain sixty centimeter lines in the British sector of the front. From this time on, the work of the division spread gradually throughout the front-line area, and with the entry of American combat troops in I9I8, it became an important factor in operations. At the date of signing the armistice, the division of light railways had under its control about $\mathrm{I}, 400$ miles of sixty centimeter track. Of this total $\mathrm{I} 70$ miles had been originally constructed by the French, but rebuilt by the A. E. F.; I 40 miles had been entirely built by the A. E. F., and I,090 miles had been taken from the Germans.

The road-service section of this department operated exclusively in the advance section; at the close of active operations the total troops it employed amounted to 28,260 men.

5 This service was directed by General McKinstry. 
Among the numerous subdivisions of the special engineer services, the following should be particularly mentioned.

The Camouflage Section was authorized on December 4, I9I7. Its main installations were located at Dijon, Paris, and Nancy. More than 3,000,000 square yards of camouflage material were produced by these workshops.

The Searchlight Service had some advanced elements in France as early as August, I917, but was actually organized only in the early part of igr8. At the close of hostilities, it had at the front a regiment of ten companies split up into operating units of $\mathrm{I}$ officer and 50 men each. Searchlight troops were charged with the defense of congested forward areas and of important advance S. O. S. installations. During the Argonne-Meuse operations these troops effectually sealed with their lights an area covering approximately 390 square miles stretching northwest from Dieulouard.

The 37th Engineers, Colonel T. H. Dillon commanding, authorized in December, 19I7, was responsible for the installation, operation, maintenance, inspection, transfer, and salvage of all stationary, electrical, and mechanical plants other than those controlled by staff departments or other services not included within the engineer department.

The Water Supply Service was charged with water supply in the zone of the armies. It also investigated the underground water possibilities in the areas where American hospitals, depots, or camps were to be located. A considerable number of wells were drilled at various points.

A special Geological Section was organized in r9i8. 
It supplied data to the staff and to the services on geological conditions at and near the front, and also compiled information on French, Belgian, and German coal, iron, and other mineral resources.

The varied and important works carried out in France by the American engineer service required enormous quantities of material; 3,948, IO I short tons altogether; I,606,332 tons were procured through importation from the United States, the rest, i. e., 2,34 I,569, was almost entirely supplied in France. A certain portion of purchases were, however, made in England, and some others on a smaller scale in Switzerland and in Spain. Portugal supplied 600,000 railroad ties. Important contracts were drawn up in Paris by the representative of the service of engineers in the General Purchasing Board. And in this connection it may be interesting to mention a fact which shows the elasticity of the American services in dealing with divers circumstances. Take for example the question of cement supply. At first it was brought from French, English, Swiss, and Spanish mills. Later on, three French cement mills were leased from their owners by the American Expeditionary Forces and operated entirely by American engineer troops. In addition, four other French mills were supplied with coal and labor in return for the cession of a portion of their output.

Every one profited in a combination of this kind. The French manufacturer was no longer confronted with the possibility of seeing his mill remain inactive on account of shortage in labor or fuel. By manufacturing itself, the American engineer service found the best guarantee against delayed production or poor quality of material. Finally, on the other side of the Atlantic, the services in charge of sea transportation were freed from the anxiety 
caused by the shipment of the 2 I5,000 tons of cement which the American engineers had found in Europe.

This is merely one instance selected from a large number of equally striking ones. We believe it to be of interest illustrating as it does the way in which this great department, thanks to the elasticity of its methods, was able to face all difficulties, and to justify the high reputation which American engineers have always enjoyed in Europe.

General Pershing had thoroughly taken into account the importance of the air service; from his personal studies of aviation in the British and French armies he was able to form an idea of the ever-increasing development of aërial warfare. From the time that his headquarters were organized at Chaumont he entrusted General Kenly, with Colonel Mitchell as his assistant, with the duty of laying down the first organization projects, of preparing contracts for material, and of directing the training and recruiting of the personnel. ${ }^{6}$

When General Kenly was called upon to perform other duties in the United States he was replaced by General Foulois. Towards the middle of January, I 9 i 8 , the new chief of the American air service distributed his department among eight sections, some of which were located at Chaumont (interior services, administrations, operations), some at Paris (technical section, supplies), and some at Tours (training, personnel, aërostatics).

At the end of February, the Chaumont sections were transferred to Colombey-les-Belles, near Toul, and there only remained at American headquarters three officers

${ }^{8}$ The contracts were made by Colonel Bolling, killed on the battlefield March 25, 1918. 
belonging to the air service who were charged with liaison duty between their service and the sections of the General Staff.

In the early part of June, when American aviation entered into a period of active production and operations, General Pershing slightly altered its organization.

General Patrick, appointed to the post of chief of air service at Chaumont, was especially in charge of the organization of aviation units.

The training sections remained at Tours; those concerned with the production of material were stationed in Paris.

The services in the advance section were directed by General Foulois, whose headquarters were established first at Colombey-les-Belles, later at Toul.

With a view to explaining as clearly as possible the necessarily complicated question of organization of the American air service, we shall examine first the steps taken to secure material, then those relating to the recruiting and training of personnel, and finally we shall observe the manner in which material and personnel were brought together to form the aviation units, and how the latter were provided with the organizations necessary for supplying repairs. To conclude, we shall see what use was made of them during action.

During I9 17 large contracts for machines and motors were drawn up by the American Government with manufacturers in the United States. The machines which were ordered belonged to the following foreign types ${ }^{7}$ (not including instruction planes) :

7 To this list may be added the two-seater Lepère pursuit plane, the construction of which was stopped by the armistice before it was completely under way. 


\section{The American Army in the European Conflict}

Pursuit plane, Bristol and S. E. V.

Day bombardment and observation, De Haviland IV and IX.

Night bombardment, Caproni and Handley-Page.

In January, I9I8, it was believed that the following machines would be available by July ist:

$$
\begin{array}{ll}
\text { 2,000 Bristol. } \\
\text { 5,500 De Haviland IV or IX. } \\
\text { I,250 Caproni and Handley-Page. }
\end{array}
$$

As to the engines, 22,500 Liberty motors had been ordered including, 2,500 for the navy. I 5,000 were to be delivered by the end of May.

These provisions were not, however, realized. As is generally known, these figures did not sufficiently take into account the difficulties involved in starting such manufactures on so gigantic a scale, and the anticipated results were far from being achieved.

In fact the first planes of American make arrived in France only in May, 1918. By July ist some two hundred of the De Haviland IV type were available. The first one arrived at Colombey-les-Belles on July 4th. At that date, beside the engines which formed part of a constructed machine, there were a very limited number of replacement engines.

The lengthy delays which had to be reckoned with in the importation of American-made airplanes had not been overlooked by the heads of the American air service in France, and from the start every endeavor was made to palliate the shortage by purchase in Europe.

The contracts signed with the French Ministry of Aëronautics provided for the delivery of a certain num- 
ber of antiquated models which might nevertheless be used by the air squadrons which were engaged in training, as well of some machines of recent model (Spad, Salmson, Breguet, and Nieuport 28) for the squadrons engaged in actual fighting.

As a result of the very considerable requirements of the French aviation at that time, the delivery of planes to the American services was at first subjected to certain delays; but from the month of May on, they were made with great regularity. From the entry of the United States into the war up to the date of the armistice, the air service of the American Expeditionary Force received in all 6,364 airplanes, 3,2 10 of which were service and $3, \mathrm{I} 54$ instruction machines:
4,874 supplied from France,
258 supplied from England,
I 9 supplied from Italy,
I,2 I 3 supplied from America and which were all of the De Haviland IV type and pro- vided with Liberty engines.

Furthermore, 870 replacement Liberty engines were sent from the United States.

The American pilots were of two categories:

The first class arrived from America already possessing a good elementary notion of their work and having obtained an R. M. A. license.

The second category was recruited from the forces of the American Army in France and at once received elementary instruction either in Chateauroux (in the French school) or at the American school at Tours. Both classes were given final complementary instruction 
at Issoudun, with the exception of those which, being destined for bombardment duty, were sent for a course of special instruction to Clermont-Ferrand.

In the month of January, I9I8, 40 pilots graduated from Issoudun with a thorough knowledge of their business; in April of the same year, 270 were ready for service. In all, from November, 1917, to the signing of the armistice the Issoudun instruction center formed 2,200 pilots while that of Clermont turned out 279.

The observers also came from two categories:

Those coming directly from America, where they had received a summary training, were for the most part at once sent on to Tours for preparation in their specialty. ${ }^{8}$ From Tours the observers intended for bombardment went to complete instruction at Clermont-Ferrand, while those destined to "observation," properly speaking, terminated their course at Chatillon-sur-Seine and in the artillery instruction camps. A certain number were also sent to complete a course of aërial gunnery at Cazeaux first, and at St. Jean des Monts - dating from June, I9I 8.

Other observers were recruited directly in the American Expeditionary Forces. Up to October I, I9I8, when General Foulois took command of the air services in the zone of the rear the recruiting of the latter class of observers presented many difficulties. After that time a fair number of good observers were selected among the officers who had recently graduated from Saumur. Observers of the latter category, who were exclusively intended to carry out artillery observation work, perfected their training - as was also the case for certain graduates

${ }^{8}$ Some were sent directly to Chatillon-sur-Seine. 
of the Tours school - in the training centers of Coetquidan, Souge, Meucon, Valdahon.

The school at Tours graduated 876 aviators, Chatillonsur-Seine 400 observers, of all arms; Clermont-Ferrand 328 bombardment observers; the artillery training centers trained I 50 artillery observers taken from the Expeditionary Forces.

In the beginning the formation of aërial squadrons was carried along the following lines:

The personnel and material which were to form the observation and bombardment units were concentrated at Amanty. The squadrons which were at first equipped only with planes of antiquated type continued their training up to the time when planes of more modern type became available. Training was permitted with these new machines, up to the departure for the front; during that period expert observers and pilots helped in the instruction of those more recently arrived. $U p$ to the latter part of January, I9I 8 , a French squadron was stationed at Amanty and assisted in the training of the American units. By April ist five squadrons had thus been organized; four for observation, one for day bombardment.

Pursuit squadrons were organized after the same principles. But their personnel and material were assembled at Epiez. By April I 5 th, four units of that type had been formed.

It must now be recalled that already and even long before the entrance of America into the war, an American aërial unit had been fighting in France whose name will be forever remembered in the history of aerial warfare: The Lafayette squadron.

Consisting almost entirely of American personnel, this 
unit was incorporated into the American air service with the number IO3, after the French personnel heretofore attached to it had been replaced entirely by Americans.

It continued, however, its service in a French combat group up to June, I9I8, when it was transferred to the first American combat group.

From April, i9 1 8, on, the methods according to which air-service units had been organized, were modified. The personnel and material which were destined to the makeup of new squadrons whatever the ultimate destination of the unit might be, were assembled at Colombey-lesBelles. There they remained for a period of about three weeks, during which time they perfected training and afterwards departed for the front.

Thus up to the date of the armistice the following units were organized:

$$
\begin{aligned}
& 20 \text { pursuit squadrons (five groups), } \\
& 6 \text { day bombardment squadrons (two groups), } \\
& \text { I night bombardment squadron, } \\
& \text { I } 8 \text { army or army corps squadrons, } \\
& 3 \text { instruction squadrons. } \\
& \text { Total, } 48 \text {. }
\end{aligned}
$$

Twelve of these were equipped with American-made planes; besides, on November I I, I9 I 8, six squadrons three for pursuit and three for observation - were in process of organization at Colombey-les-Belles.

The general system for supplies and repairs adopted by the American air service was based on two principles:

Firstly: To establish at the rear a big assemblage and repair shop whose duty was to mount the planes which

9 This squadron was never actually employed on account of the a rmistice. 
were sent from America in separate parts and to execute important repairs. This shop was organized at Romorantin on a large scale. The body and engines imported from the United States were thoroughly looked over and definitely mounted. The machines were equipped in machine guns, in photograph and telegraph apparatus; they were then subjected to tests, after which they were sent to the front. Airplanes that had been seriously damaged at the front were thoroughly overhauled in these shops. Out of a total of I, I 3 De Haviland IV planes received from the United States by November, I9I8, I, 087 were mounted at Romorantin, and 628 were forwarded from there to the front. In the course of the same period the Romorantin shops repaired 308 machines.

At Orly an important " acceptance" park was established for the tests of airplanes purchased in Europe 3,300 planes went through their tests at this place. On a certain date, 9I machines were sent to the front by the reception park at Orly. This is believed to be a record in operations of this kind.

Secondly: To establish in the zone of advance and for each army and for each pursuit or bombardment group, a park intended to do ordinary repairs and ensure the daily supply of fighting units. Behind these parks were to be established a certain number of air depots whose rôle was to execute more important repairs and to supply completely mounted planes. Finally "aërial reception centers" were to group the material intended for distribution to the air depots, while the schools were to repair their damaged planes by means of their own resources.

As a matter of fact, the army and group parks were never organized. 
Out of the five air depots contemplated, only one (Colombey-les-Belles), which started operations in the month of April, was actually completely organized.

At the date of the armistice it had overhauled 237 planes, and held 298 ready for employment.

Four aërial reception centers had been foreseen. One was begun at Is-sur-Tille, but was never brought to completion; it was afterward replaced by a large depot, the construction of which was begun at Latrecey in August, I9 I 8 , and was well under way at the time of the armistice.

Thanks to the value of American pilots the air service of the American Expeditionary Forces was able to render excellent service in all the branches of aviation which called for audacity and skill. The pursuit squadrons scored as well on the American front as on those of the French and British armies a very great number of victories. ${ }^{10}$

The bombardment squadrons also greatly distinguished themselves in the attack of enemy rear organization. ${ }^{11}$

The technical training of observers (employment of wireless telegraphy, photography, use of machine gun) has always been excellent. ${ }^{12}$

From a tactical point of view great difficulties were encountered by the Americans in the work on the "plan directeur" on account of their ignorance of the metric system.

Two pursuit squadrons were engaged at the British

10753 planes and 71 enemy balloons were brought down. Total losses of the aviation of the American Expeditionary Forces, 357 planes.

11 American bombardment squadrons executed on the Western front a total of 150 raids in the course of which 115 tons of high explosives were dropped on the enemy.

12 18,000 photographic negatives were taken and 585,000 reproductions made. 
front from March to September, I9I8. From January to the end of August all other American units were engaged on the French front as soon as organized: the pursuit squadrons individually at first, afterward, incorporated in groups, took a very brilliant part in the defense of the Lorraine front, and later in the operations on the Marne and Aisne. The bombardment squadron No. 96 was employed in the blockade of the mineral basin of Lorraine. The observation squadrons were, as soon as ready, assigned to American divisions, and later to army corps; they took part in the operations carried out in the Vosges, in Lorraine, and were afterward engaged with the first American Army Corps in the region of ChâteauThierry.

When the first American Army was organized all the aviation units then available were assigned to it, i. e.:
3 pursuit groups (I 2 squadrons), Bombardment squadron No. 96,
2 army squadrons,
9 army corps squadrons.

These forces were naturally insufficient to carry out the amount of aërial warfare involved in such extensive operations as the Saint-Mihiel and Meuse-Argonne offensives, therefore French aviation units to the extent of some fifteen artillery squadrons and one night-bombardment group returned, on this occasion, to the American Expeditionary Forces the powerful assistance which they had given to the French air service in the operations on the Marne. Moreover the French aërial division participated in the activities of the American aviators. As soon as American squadrons had been formed in sufficient numbers, the French units were turned back to their nor- 
mal destination. At the date of the armistice the aviation of the three armies which then composed the American Expeditionary Forces exclusively consisted of American units. ${ }^{13}$

Aërostation followed a development parallel to that of the aviation. However, it should be mentioned that almost all its material was imported from the United States, and that it always was available in sufficient quantities to meet requirements.

The observers, part of whom were recruited in the artillery brigades and trained in the centers of Valdahon, Meucon, Coetquidan, La Courtine, Clermont-Ferrand, Le Courneau, Mailly, and in the beginning at Vadenay while the others underwent a preliminary course of training in America and afterward perfected their instruction at Souge, always gave most complete satisfaction.

The balloon companies were grouped by fours in America, and upon their arrival in France went into training schools where observers were assigned to them; afterward they were sent to the front.

The first American balloon company appeared at the front in Lorraine in February, I 9 I 8.

When the first American Army was organized fifteen balloon companies were assigned to it, all of which had been engaged with American divisions and army corps on different parts of the French front.

This number being insufficient, some ten French companies were in the beginning assigned to the First Army, and afterward turned back to the French command as soon as American companies became available for service.

At the date of the armistice there existed in France a

13 General William Mitchell, well known to his French comrades for his admirable energy in action, commanded the active operations of the American aviation. 
total of thirty-five companies, twenty-four of which were at the disposal of the fighting forces.

In all 295 balloons were received; 20 had been supplied by France, 275 came from the United States.

Of all the component parts of a large army obliged to organize itself at the same moment as it goes into action, perhaps the most difficult to handle and engage is the service of aviation. The material as well as the mode of employment were constantly being modified in the course of the war. The big units, i. e., the pursuit and bombardment groups, can only be thoroughly efficient if the squadrons of which they are composed are absolutely conversant with concerted maneuvers and possess pilots and observers fully qualified by their tactical and technical training.

To conclude, it must be mentioned that no time whatever was lost, since General Pershing always gave the allied armies the assistance which was consistent with the means which he had at hand, lending American machines to fill up the losses in the French aërial ranks while waiting for the formation of, strictly speaking, American units.

To the Signal Corps of the American Army falls the work of providing methods and means for the communication of intelligence for military purposes by telegraph, telephone, radio, or otherwise; and also of providing the personnel for the construction necessary to these communications as well as for their operation.

Its sphere of activities extended from seaport to front.

It had representatives as well in every territorial zone of the rear as in the main fighting units - armies, army 


\section{The American Army in the European Conflict}

For practical purposes the work of the signal corps may be divided into two fields which we will in turn examine:

First: The construction, operation, and maintenance of every sort of electrical communication from base ports through the zones of the S. O. S. up to the front.

Second: Communication by every practicable means within and between the units of the fighting forces.

The first of these requirements rendered necessary the provision of a network of lines of communication between ports, depots, hospitals, aviation centers, and training camps; in short, a complete system on a large scale connecting all points where units or offices of the American Expeditionary Forces were located.

This called for the construction, installation, and operation of telegraph, telephone, and radio equipment analogous in every way to that necessary in commercial systems such as those in the United States.

The facilities which the French were able to place at the disposal of the signal corps were early found to be inadequate, and signal corps lines built with American material by their own personnel were constructed in steadily increasing numbers.

From the twenty-fourth of June, I9 17, when the signal corps commenced its function, up to the first of May, I9I9, there had been over 40,000,000 local telephone calls and upward of I,350,000 long distance telephone calls handled by its services.

Since the signal corps telegraph system began its work on August 9, I9I7, there have been handled more than I 2,000,000 telegraph messages.

The long distance telephone and telegraph system which they constructed were entirely maintained by a 
signal corps personnel. In addition 19,800 miles of leased wires were also maintained by it.

Although the main duty of the signal corps is to provide communication, a large part of its activity had to do with its own supplies. These consisted of all the implements and material for constructing lines of communication, including equipment of central stations and telegraph offices, as well as all the instruments and apparatus used for signaling in combat. Finally, the signal corps was charged with meteorological and photographic services to the entire army, and supplies for these activities were under its control.

The second field of activity of the signal corps was concerned with the provision of tactical units fully equipped and trained in the use of every practicable method of signaling promptly and despite enemy interference, with the interception of enemy communications and the location of enemy radio stations, whether on the ground or on airplanes. The interception of communications and the location of radio stations of the enemy was done by carefully trained personnel working with special apparatus in coöperation with the intelligence section of the General Staff. The utility of this organization, by means of which we were able to learn the enemy's plans in advance, and to gain valuable information upon the character and distribution of his units in the battle line, is to-day widely known.

At the time of its greatest activities the signal corps operated in Europe 14,854 telephone stations and 396 exchanges. The total length of wire employed for telephone or telegraph purposes was 13,000 miles - over five times the length of the terrestrial meridian. 
The construction and operation of such a system called for a personnel possessing a very high degree of technical skill. Most of it came from the personnel of the telephone and telegraph companies in the United States.

Units of the signal corps were of two types:

telegraph battalions,
field signal battalions.

A telegraph battalion consisted of 10 officers and 2 I 2 men; they were very completely equipped.

They were charged, in the zone of the S. O. S. with construction and maintenance of the pole lines and buried cable lines generally established along roads and railroads. Telegraph battalions attached to armies and army corps installed telephone and telegraph systems connecting headquarters in the zone of the armies. Since most of the personnel of these battalions had been engaged on similar work in civil life, no very extensive or special training had been necessary for them, aside from that of a military character.

Field signal battalions were especially charged with service at the front. One of them was assigned to each army, army corps, or division of infantry.

It is interesting to say a few words about their organization. They consisted of :

I headquarters and supply section. .3 officers 29 men

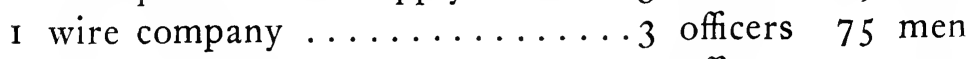

I radio company $\ldots \ldots \ldots \ldots \ldots 3$ officers 75 men

I outpost company ..........5 officers 280 men Total, I 4 officers 495 non-commissioned officers and men.

The headquarters and supply section performed the 
administrative services of the field signal battalion. It distributed accumulators and carrier pigeons.

The wire company installed, maintained, and operated telephone and telegraph systems from division headquarters inclusive to, but not including, regimental headquarters. Besides it was prepared to handle all forms of visual signaling when other means failed.

The radio company installed and operated radio stations at brigade headquarters, division posts of command, and at those of the artillery battalion. It also operated the wireless ground telephone sets and listening sets, as well as gonio stations installed in the division area.

The outpost company was divided into:

I headquarters detachment, I captain and 20 men

4 regimental platoons each of I lieutenant and 65 men.

The headquarters detachment was available for the purpose of strengthening the regimental platoons when necessary.

During the period of trench warfare, each regimental platoon was permanently assigned to a regiment of the division. In open warfare the outpost company was divided into two sections, which were charged with maintaining the liaison between brigades and regiments.

The training of this personnel for signaling in combat, especially the training of the different groups of the field signal battalions, was carried on partly in the United States and partly at signal corps schools, in training areas, and in quiet sectors of French front. Besides learning the duties of a soldier, each man was to gain an intensive knowledge of his own special functions, also a wellgrounded experience in signaling generally. While sig- 
nal corps troops are not combat units, they endured all the dangers incident to combat and gave repeated examples of their courage and resourcefulness under the enemy fire.

The first members of the signal corps to reach France arrived on June I3, I9I7. Besides the chief signal officer, Colonel Russell, ${ }^{13}$ there were six officers, six soldiers, and two civilians. On November I, I9I8, the total reached I, 462 officers, 33,038 soldiers, and 323 civilians, including women telephone operators.

One of the chief accomplishments of the signal corps during the war was the successful equipment of combat divisions with the special signaling apparatus required in modern warfare. Much of this apparatus, especially radio equipment, was new to America, and consequently had to be found in Europe. Approximately four and a half millions of dollars were spent on material purchased in France.

The telegraph and telephone equipment was imported from the United States. In order to minimize the effect of the submarine warfare on the supply of these most important materials, shipments were made in ten-mile lots. Each ten-mile lot of material contained everything for that distance of line ${ }^{14}$ and was loaded on a separate ship.

The signal corps operated seven supply depots and three army parks when the armistice was signed. The total tonnage of supplies received amounted to approximately I00,000 tons, 62,000 being from the United States, 37,000 from France, and I,00o from Great Britain.

13 Colonel (afterward General) Russell was chief signal officer throughout the entire war.

14 With the exception of poles which were obtained in France. 
From December I, I9I 7 , to November I, I9I8, the signal corps photographic division exposed in the field and developed in its laboratory seventy-five miles of original moving-picture films.

In the course of the war the signal corps had recourse on a large scale to the resources of France. In this connection it is perhaps sufficient to mention radio and radiogoniometric equipment. Let us incidentally recall the fact that the allied armies made a constant appeal to French industry for the supply of photographic cameras, and of all high grade optical glass.

This being said, we will be the more at liberty to acknowledge that upon one point - and a very important one - we have everything to learn from the American signal corps. We mean in the organization and operation of the telephone system. No one that has had occasion to put in a call from Coblenz to Bordeaux from Chaumont to Brest or to London on the American lines will, in our opinion, contradict this statement. It may be remembered that the personnel and material on these lines were the same as those which, in the United States, ensured communication by telephone between New York and San Francisco.

What may we suppose are the reasons for American superiority in this branch? Are they to be found in a better quality of material, in greater professional skill on the part of the operators? Are they due to better organization, or more efficient methods of operation?

We will leave it to our own technical specialists to seek the answer to the above questions.

When the first elements of the American Expeditionary Forces arrived in France, their chief surgeon, Colonel 
(later Brigadier-General) Alfred E. Bradley, found himself confronted with a very heavy task.

The soldiers from the United States, very recently drafted, were about to enter into active operations in a country the climate of which was very different from their own; they were furthermore quartered in billets, a thing entirely new to them. Therefore not taking into account the casualties arising from enemy action it was certain that the sick rate among the troops would be fairly high. On this account it was necessary to foresee and organize a very' important system of hospitalization.

As was natural most of the large buildings in France which would have been appropriate to such a service, were already utilized for the requirements of the allied armies. It was therefore necessary to erect new shelters and the material for the construction of barracks was in those days very scarce.

As soon as the United States had declared war, Colonel Wadhams, then a member of the American Mission of Observers, had approached the French Minister of Public Health in regard to the measures to be taken. In close coöperation with Chief Surgeon Castelli (French Army) he had made very thorough investigations of the facilities which, by cutting down their own requirements in every way, the French service could place at the disposal of the American Expeditionary Forces.

From that time on, a period of constant and intimate coöperation was initiated between the medical authorities of the two armies; the results were of the most satisfactory character.

We must here limit ourselves to a description of the activities of the American medical corps in its operations carried on from February, I9I8, under the suc- 
cessive direction of Generals Bradley, Ireland, and McGraw.

As every one knows, sanitary organizations are divided into two main categories: Those which are mobile and follow all the displacements of the troops to whom they are attached; the others which are fixed and naturally offer greater advantages for the treatment of patients.

The chief surgeon, whose headquarters were at Tours, was especially preoccupied with questions pertaining to general organizations, to personnel, supplies, and the establishment of fixed hospitals intended for the care of patients coming from the French front or from other points.

Although his authority extended to all American sanitary formations in Europe, by reason of the great distance which separated his headquarters from the front, it was necessary for him to delegate to a deputy stationed at headquarters the portion of that authority which had more especially to do with the armies in the field. Colonel Wadhams was appointed to that very important position. He was made a member of the fourth section of the General Staff, and, in the name of the commanderin-chief, coördinated all medical activities at the front.

In the American Army the medical department was organized by divisions at the headquarters of each of those units, a lieutenant-colonel belonging to the medical corps was in charge of all the sanitary personnel operating with the division. Under his orders was the divisional sanitary train consisting of :

$$
\begin{aligned}
& 4 \text { ambulance companies, }{ }^{15} \\
& 4 \text { field hospitals, }{ }^{16}
\end{aligned}
$$

15 Three automobile and one horse-drawn ambulances.

16 Three automobile and one horse-drawn ambulances. 


\section{The American Army in the European Conflict}

\section{I medical supply unit, \\ I mobile laboratory.}

Each ambulance company had fifteen vehicles, twelve ambulances and three trucks. The field hospitals were equipped with tents and an important material transported on trucks or wagons; each of them could take care of 2 I 6 patients. Thus the divisional sanitary train had a total strength of 50 officers and 90 I enlisted men.

Besides each regiment disposed of a medical detachment ${ }^{17}$ the sanitary train of the army corps comprised, not including, of course, the sanitary formations of the division:

3 field hospitals,

3 ambulance companies.

The army sanitary train, besides the sanitary formations of the corps, included in the army, comprised:

4 field hospitals,

4 ambulance companies.

Besides, the army surgeon disposed of:

2 evacuation hospitals, ${ }^{18}$

I mobile hospital ${ }^{19}$

per division included in the army.

Furthermore the chief army surgeon disposed of mobile surgical and degassing units, several sections of army ambulance service, convalescent depots, medical

17 Seven surgeons and 48 enlisted men by infantry regiment.

18 These were generally established under tents and had a capacity of 500 to 1,000 beds; they were well equipped and were able to undertake surgical operations of the greatest delicacy under the most favorable conditions.

${ }^{19}$ Established along the same lines as the French auto-surgical ambulances. 
supply parks, field laboratories, special operating teams (shock, gas, etc.) and hospital trains for the evacuation of patients to the rear.

At the time of the Meuse-Argonne offensive, the facilities controlled by Colonel Stark, army surgeon of the First Army, approximated 30,000 medical department personnel. When an American soldier was wounded in the firing line, he was at first taken to the battalion or regimental first-aid station which was the most advanced post of the sanitary service. From there he was transferred to the ambulance bandaging station, which was installed at the extreme limit of the zone accessible to motor transportation. Men who were only slightly wounded came unaided to this station, the others were carried by stretcher bearers. From there the wounded were transported to the sorting station which was directed by one of the field hospitals of the divisional sanitary train.

Slight cases, especially those affected with "psychoneurosis " or shell shock, were held at the sorting station; the more serious cases were divided among the other three field hospitals of the division. From there the sanitary train belonging to the army corps reënforced, in case of emergency by ambulance companies belonging to the army, transported them to a mobile evacuation hospital, both of which were army organizations; they were then placed on board hospital trains and taken to the base hospitals of the interior.

It had been agreed in principle that, when American troops were to take over a sector at the front, they would take charge of all existing French formations and provide for the care and evacuation of their own patients. The hospitalization of the American Army was therefore organized upon this basis. 


\section{The American Army in the European Conflict}

Practically, some difficulties were encountered. As a consequence of the German drive of March, I9I8, which compelled the high command to engage American divisions on different points of the front, the working of this system was extremely complicated. The American medical corps was not in a position to supply evacuation hospitals and hospital trains to all American divisions who were isolated among the French armies. It was therefore found necessary to receive American patients in French sanitary formations, and to evacuate them in French hospital trains toward the interior. It was agreed that as soon as their state of health would permit, these patients should be transferred from the French hospitals which had received them to the nearest American hospital. On the other hand, American hospitals receiving French patients were to transfer them as soon as possible to French sanitary formations. As a whole, and notwithstanding the difficulties arising out of the difference in languages, these arrangements worked in a most satisfactory way. Nevertheless it seemed desirable that the Americans might, as soon as practicable, be in a position to provide for the entire care and evacuation of their own patients from the time when a sector of the front should be definitely assigned to them. This was the case from date of August, I9I8, before the battle of Saint-Mihiel. From that time on, the American Army itself provided for the care and evacuation of its own sick and wounded.

In some cases at Château-Thierry, in Champagne, and later on in Flanders, it was even possible to establish American evacuation hospitals in the rear of those American divisions which were fighting in the ranks of French armies. 
Difficulties were experienced in securing hospital trains. The American medical department was, however, able to purchase twenty-one of these: Two in France, nineteen in England. ${ }^{20}$

But this number was insufficient to meet the requirements of the Expeditionary Forces during the summer and fall of 19i8. It was therefore necessary for the French Government to place at the disposition of the American medical department a very considerable number of hospital trains. In the latter period of the war the number of such French trains in the American service was fortyfive.

We must now leave the zone of the armies and deal with medical corps activities in the interior. The organization was adapted to the zone of the rear in base, intermediate, and advance sections.

In each a section chief surgeon controlled the existing permanent sanitary formations: Base and American Red Cross hospitals, convalescent depots, laboratories, stores, centers of muscular reëducation, shops for repair of sanitary material, workshops for erection of sanitary automobile material, schools for medical and surgical specialties. As has already been said, the French authorities had put at the disposal of the medical department all available permanent constructions and barracks. Moreover, the French engineers gave great assistance by drawing up plans for such establishments and laying down railway tracks.

The number of beds thus made available increased rapidly. Following figures include only those permanent

${ }^{20}$ Each of these trains was capable of transporting from 300 to 400 stretcher cases. 


\section{The American Army in the European Conflict}

hospitals located in the interior; those with the armies being temporary installations are not mentioned.

The week ending November 7, I9 I8, saw the greatest number of patients in A. E. F. hospitals, when a total of I 90,888 beds were occupied. On the day the armistice was signed, there was a total of 283,553 beds in the hospitals of the interior. On the same date there were in operation I 53 base hospitals, 66 camp hospitals, and I 2 convalescent camps. From December I I to December 5 , I 9 I 8 , the total number of beds was increased to 296,835 . The construction and installation work under way was to raise that figure to 423,772 normally, and 54I,000, in case of emergency.

At the time of the armistice, the American medical department in France had grown, so that there were with the Expeditionary Forces I6,407 medical officers, 8,593 nurses, and I26,23 I enlisted men. Moreover, there were in the United States nearly as many more awaiting transportation to France.

The medical supplies on hand were sufficient to meet all requirements. Let us mention in passing: 190,280 pounds of sulfuric ether, 275,075 gallons of alcohol, I,I35 gallons of iodine, 4I,372,640 gauze bandages, 3,081,727 first-aid packets. At the close of hostilities, the American medical department had most successfully overcome all the difficulties incident to the beginning of operations, and it may be unhesitatingly affirmed that should the war have been continued it would certainly have been in a position to provide, under the best and most comfortable conditions, for the care and hospitalization of the large number of casualties which might reasonably be expected from the very rapidly growing combat strength of the American armies. 
We have seen, in a preceding chapter, how numerous were the duties devolving upon the quartermaster corps. During the process of organization which took place in the Expeditionary Forces the quartermaster corps was called upon to drop certain of its attributions and take over others.

It may be remembered that as early as September, I9I 7 , the organization of the transportation department had taken from the quartermaster corps the burden of railway transit. Later on, the D. G. T. [Director General of Transportation] also took charge of operations of base ports. Finally, in February, I9I 8 , the motor transportation service was, in its turn, made independent.

At the time when its chief, Quartermaster General Rogers, ${ }^{21}$ transferred his headquarters to Tours, the duties of the quartermaster corps were as follows:

Payment of personnel and general disbursements, subsistence, fuel and forage, clothing, remount service, laundries and baths, disinfection of clothing, salvage service, quartermaster shops, depots and storehouses, cold storage and refrigeration, graves registration service, inspection of quartermaster activities. To these manifold duties were later added: Garden service, all disinfection for troops in the zone of advance with the exception of that carried out in hospitals, finally, organization of railhead supply units.

In order to carry out so many divers and important functions, General Rogers had organized his central office as follows:

21 General Harry L. Rogers was appointed quartermaster general of the United States Army on July 22, 1918. He remained in France up to the end of the war, and left Tours on January 31 , 1919, to take over his new post in Washington. 
The inspection service reported on such matters as supply of divisions, finance, conditions of remount service, bakeries, etc. This important work was carried out by a varying number of traveling inspectors.

The administrative section included the handling of all records, mail, telegrams and cablegrams, precedent and research, and administrative action on contracts.

The personnel division handled all matters pertaining to the quartermaster personnel, such as organization of new units, including labor formations.

The finance division included the supply to disbursing officers of the funds which they controlled, instructed these officers in the nice legal points of their studies, and adjusted certain classes of claims.

The accounting division included the examination and analysis of accounts - property and funds - and audit of subsistence returns of the quartermasters in Europe.

The supplies division. The most important of the chief quartermasters organizations, its activities being divided into fifteen sub-branches: Miscellaneous, clothing, subsistence, bakeries, animal-drawn transportation, traffic, traveling-officers, supplies and stationery, fuel, forage, cold storage and refrigeration, administration, garden service, storage and warehousing, gasoline and oil.

Quartermaster supplies were provided from three different sources: requisition in the United States, purchase made directly in France, by the purchasing agent of the quartermaster, contracts made with the French and British governments.

The salvage service operated in France seventeen depots and shops with a personnel of 150 officers and I 7,000 male and female employees. ${ }^{22}$ It ran the shops 22 Sixty-seven per cent. of the day shifts were composed of Frenchwomen. 
for recuperation of fats, laundries, and disinfecting plants, finally it took charge of the sanitation of battlefields, a service in which tens of thousands of men were employed simultaneously.

The remount division, with a strength of 400 officers and 8,00o enlisted men, operated sixteen depots at the date of the armistice.

The graves registration service included the acquisition, maintenance, and control of cemeteries; identification of the dead; registry of burials, and correspondence with relatives of deceased soldiers.

All these services were again subdivided into numerous branches; such division of labor being necessitated by the immense volume of work involved and the need of having tasks so apportioned as to secure intelligent supervision, by commissioned heads of various branches.

Many of these officers were men who, in civil life, were accustomed to handling extensive business operations, and were usually specialists in the branches assigned to them.

The quartermaster corps was represented in the various sections of the services of supply by a chief quartermaster on the staff of the commanding general of the section. Armies, ${ }^{23}$ army corps, ${ }^{24}$ and divisions ${ }^{25}$ each had their quartermasters on the staffs of their respective commanders.

Such were the general lines of an organization which, at the close of hostilities, provided for the supply of 2,000,000 men, and operated a total of 844 installations distributed among 267 different localities.

23 Members of G-4.

24 Members of G-4.

25 Members of G-I (division headquarters had no G-4). 


\section{The American Army in the European Conflict}

Let us glance at the results achieved.

The bakeries which were distributed in sixty-seven towns had a daily output of I, ooo tons of bread. Seventeen refrigerating plants were in operation with a capacity of Io,000 tons, fifteen others, with a capacity of 16,000 tons, were under construction or projected. Fifty-eight quartermaster corps gardens had produced, up to November I5, I9I 8 , approximately $75,000,000$ pounds of vegetables at a cost (not counting the labor of enlisted men) of about one-third of the prevailing prices,

A total of I,OI 6,622 tons of coal had been imported from England between October I, I9I7, and October 31, I9I8. The shipment of British coal for the A. E. F. had grown from 28,338 tons in October, I9I7, to 207,630 tons in October, 19 I 8. There were eight cold storage yards in the A. E. F. with a total capacity, ultimate storage, of I,2 I9,000 tons.

The gasoline and oil storages established in the vicinity of the base ports had a total capacity of $6,323,290$ gallons; those in the intermediate section a capacity of 2,300,290 gallons. There was a total of twenty-seven storage and distribution stations in operation with sixtysix similar installations projected. Finally, seven French depots and oil refineries were utilized by the Expeditionary Forces. The strongest deliveries to the army services were made in October, I9 18: 9,675,200 gallons to the motor-transport service; $1,458,600$ to the aviation; 374,900 gallons of kerosene to the bulk of the services; I 50,000 gallons of castor oil and 503,600 pounds of grease.

The service of remounts had been confronted with grave difficulties originating in the lack of sea tonnage 
and the scarcity of animals on the European markets. A total number of 243,560 horses and mules were delivered to the A. E. F.: I 36, I I 4 were bought or requisitioned in France; $2 \mathrm{I}, 259$ came from Great Britain; I 8,462 from Spain; 67,725 had been imported from the United States.

Up to the date of November I I, I9I 8 , there had been imported to France I 45 , 000 tons of hay, 2 I 5 , 000 tons of oats; 17,300 tons of bran.

The salvage service, created on January I6, I9I8, secured results which it is worth while to mention. The percentage of salvage recoveries from articles shipped to depots requiring both renovation and repair aggregated 9I per cent. up to December 3I, I9I8. The remaining 9 per cent. was largely used as raw material in patching, mending, and renovation.

The total cost of the operations of the salvage service as compared with the value of output of depots and shops was I I per cent.

The total value of the output of the service up to January 3I, I9I9, was $\$ 85,469,573.4 \mathrm{I}$.

We cannot better sum up the accomplishments of the salvage service of the A. E. F. than by quoting the following lines extracted from the report of its chief, Colonel T. B. Hacker :

"What was in former wars a distinct liability has developed into a tremendous asset. Tonnage space and raw materials have been conserved and an unlimited field opened for the utilization of by-products heretofore regarded as waste."

The graves registration service installed in France more than two hundred military cemeteries. They are scattered all over the country from the historic battle- 


\section{The American Army in the European Conflict}

fields of Chateau-Thierry and the Argonne to the base ports on the Atlantic coast. The most important of these are located at Romagne-sous-Montfaucon, near Beaumont-sur-Meuse, and in the immediate vicinity of Paris near the Mont Valerian. There are also eightyfive American military burying grounds in England, a similar number in Italy and Belgium, and a few in northern Russia.

The quartermaster personnel of I 6 officers, I 2 field clerks, and io enlisted men who landed in Liverpool on June 7 , I917, had grown on December I5, i9i 8 , to 4,229 officers and 96,54I enlisted men. These figures do not include about 600 officers and 18,000 enlisted men transferred to the motor-transport corps and about 300 officers and i 3,000 enlisted men transferred to the transportation department.

The total amount disbursed by the quartermaster corps of the Expeditionary Forces from the time of the arrival of the first troops in France up to, and including, February 28 , I 919 , was approximately $\$ 568,444$,000.

The ordnance department supplied to the American Army its armament and munitions. It was charged with the choice or design of all types and models and with their procurement either by purchase or by manufacture in its own arsenals. It was responsible for the issuing of material to the troops and for its inspection and maintenance.

We will not give here a list of different materials pertaining to the ordnance (examined elsewhere); but limit ourselves to the mention of tractors, tanks, mobile repair shops, and all machinery necessary for the maintenance of ordnance material in the field. 
During the war, the different types of material were determined in Washington, but the ordnance department of the Expeditionary Forces was very frequently consulted; it acted in the capacity of a technical adviser for the Washington authorities; and ensured liaison with the allied governments.

The establishment of the ordnance department in France dates from the middle of June, 1917, when General (then Lieut.-Colonel) Williams, to-day chief of ordnance in Washington, arrived with General Pershing. The organization has been subject to a few rather unimportant changes; we will here give a description of its definite form; that is, the one it had from May, I918, to the armistice. The department was grouped into five main divisions:

administration,

requirements,

supply,

construction and maintenance,

engineering.

The Administration Division was charged with recording and filing correspondence, auditing of all ordnance accounts, publication and distribution of bulletins of information and orders, and execution of the general administration of the office of the chief of ordnance.

The requirements division was charged with preparation of all schedules for ordnance material and the placing of requisitions with the ordnance purchasing officer. It was also charged with the compilation of the various monthly reports required, and the complete record and follow up of requisitions placed, and the tonnage allotted to the ordnance. 


\section{The American Army in the European Conflict}

The supply division was charged with the supervision of all depots for the receipt, storage, and issue of ordnance material, and for their efficient and safe operation; with the maintenance of stocks and the preservation of material in the depots, with a maintenance of relations with forces in the field necessary for the satisfactory supply of their needs.

The construction and maintenance division controlled the provision and maintenance of buildings and their equipment, also the supervision of construction and the actual, work of upkeep and repair. Construction, however, was performed by the engineer corps. The division was further charged with the installation, inspection, and maintenance of machinery for the shops and the mobile and semi-permanent ordnance repair shops attached to line organizations: and finally coöperated with the salvage corps in the repair and salvage of ordnance material.

The engineering division was entrusted with the work of advising and instructing other divisions in all technical matters relating to procurement, handling, storage, and transportation of ordnance stores and supplies; with investigation of causes of defects in ordnance material, and determination of the necessary remedy; with the conduct of research work and tests at proving grounds; with the handling of matters of design, determination of types, developing of new or modification of old material; with the preparation of technical pamphlets, drawings, and charts; with preparation of tables of spare parts. It had another rôle of great importance in the work of instructing personnel.

The task of supplying the Expeditionary Forces in armament, in ammunition, in spare parts, coming both 
from Europe and from the United States, was perhaps the most difficult that confronted any administrative department of the American Army. The list of items included in ordnance supplies amounts to 32,000 articles. Ordnance material was divided into eight homogeneous groups with a special organization, office, and record system for each group. Incoming requisitions were broken up into group issue orders, each one of which covered only the material listed under one group. The system of "automatic supply" was adopted for the procurement of ordnance material; it involved the maintenance in France of a three months' supply of all kinds of material and spare parts. This method, which seems simple as a general theory, proved extremely difficult when applied to this special branch of the service. It is comparatively easy to foresee what will be the consumption of canned goods in an army of $1,000,000$ men during a specified time; it is, on the contrary, extremely difficult to determine how many rounds of ammunition of different calibers will be consumed or how many machine guns will need replacement or repair.

Nevertheless, the ordnance established "automatic supply tables" computed for each article, in the number of units necessary to supply 25,000 men for one month, allowing a liberal percentage for losses in transit or in storage. But, on account of the intensity of military operations and of the importance of unforeseen requirements put in by units in the field, the system was never completely brought into application.

The ordnance has never operated any manufacturing plant in France; the material of the A. E. F. was purchased in Europe or imported from the United States. On the contrary, at the time of the armistice it had sev- 
eral erection, repair, and charging plants in operation, or in process of construction.

Its most important installation - not completely finished at the close of the war - was the repair shop at Mehun-sur-Yèvre, the plans of which were drawn up to meet the requirements of an army of 2,000,000 men. There also existed an advance shop at Is-sur-Tille, and twenty-two installations of lesser importance.

In the field, repairs were made by means of mobile repair shops belonging to two types: a heavy and a light one. Those of the first type were equipped with 3-ton trucks (called tool room, air compressor, and forge trucks respectively) and five 5-ton trailers of the machineshop type (called lathe, welding set, drill press, shaper, and milling machine trailers). They were assigned to the brigades of heavy army artillery and to tank units. Repair shops of the light type somewhat less important were assigned to army and army-corps artillery parks and to divisions of infantry.

Eight heavy mobile ordnance repair shop organizations and twenty-five of the lighter sort were working at the time of the armistice.

Almost all artillery material and ammunition used by the Expeditionary Forces were procured in France and to a much smaller extent in Great Britain. Only a few heavy guns and ro9 $75 \mathrm{~mm}$. were imported from the United States by November II, I9I8. A few figures here will give an idea of the importance of the contracts made in Europe by the ordnance department:

3,035 $75 \mathrm{~mm}$. (3-inch) guns in France, I, I 90 I $55 \mathrm{~mm}$. (6-inch) howitzers in France, $2,55^{\circ}$ Stokes mortars in Great Britain. 
Deliveries were made at a satisfactory and regular rate. By November 30, 19 1 8, the actual deliveries were:

I, $97875 \mathrm{~mm}$. guns, from France,

346 guns and 814 I $55 \mathrm{~mm}$. howitzers, from France,

209 8-inch howitzers, from Great Britain, I,597 3-inch mortars (Stokes), from Great Britain, 559 6-inch Newton mortars, from Great Britain.

Over $10,000,000$ rounds of $75^{26}$ and I, 250 ,000 rounds of $155^{27}$ were in the same lapse of time delivered to the American Forces.

Now, to the question of portable weapons. France supplied 4,658 Hotchkiss machine-guns and 40,000 Chauchat automatic rifles. These contracts were made to meet the requirements pending the time when the United States should have a sufficient output of Browning light and heavy machine-guns (two weapons which may be considered as being by far the most perfect at present in existence), which were imported in great quantities after the summer of 19 I 8.

Not including the portable weapons with which American soldiers were equipped in the United States and which they carried with them when they carne to France the ordnance department secured as well in America as in Europe a total of 93,326 machine guns, 600,000 rifles, and 75,000 automatic rifles.

The very large contracts made in Europe were only rendered possible thanks to the activity displayed by the ordnance department in securing from America the enormous quantity of raw materials necessary. In the period

${ }^{26} 4,111,000$ have been fired.

${ }^{27} 760,000$ have been fired. 
between April I, I9I8, and the armistice only, a total of 440,000 tons were actually imported in France.

The war came to an end before the ordnance department had had a chance to see great numbers of Americanmade guns firing against the enemy American-made ammunition.

Nevertheless its rôle has been a very useful one. The chiefs who were at its head had the merit of foreseeing the delay which must, of necessity, elapse between the entry of the United States into the war and the time when their system of war material manufacture would reach a sufficient output.

They seized the right moment to adopt materials of allied make, and among these they always selected the best.

The recruiting of ordnance personnel was of necessity rather difficult. American industry had not turned the bulk of its activities toward intense production of war material. The army of the United States had nothing to compare with the excellent personnel of gun repairers and skilled artificers that the French artillery had trained in peace time.

Hardly had hostilities begun when a very active campaign was undertaken in the American universities and factories with a view to bringing about enlistment of a personnel whose technical knowledge and professional skill would furnish to the ordnance, officers, noncommissioned officers, and soldiers that it so much required.

The great factory owners, civil engineers, overseers, skilled workmen thus enlisted generally underwent a course of training in ordnance arsenals. They were afterward formed into provisional units which, on their 
arrival in France, were broken up and distributed by detachments in the installations where want of personnel was most acutely felt. Let us incidentally recall the fact that, in the course of the summer of I9I 8 , hardly any personnel except infantry troops were transported from America to France, which fact greatly handicapped ordnance activities in Europe.

On the day of the armistice the total strength of the department present in France was only I,803 officers and I 2,205 enlisted men.

However, the very high technical skill and efficiency of this personnel made up in a certain measure for their small numbers.

No sooner had he arrived in France than General Pershing gave orders with a view to the organization of the chemical warfare service, the growing importance of which was daily demonstrated by the military operations under way.

On July 5, I9I 7 , the service of engineers was charged to supply personnel and material for gas and flame offensives and the medical corps for gas defensives. All gas shell and other similar material were to be supplied by the ordnance.

On September 3, 1917, the gas service was made an independent organization. Its chief, Lieut.-Colonel Fries, later brigadier-general, was charged with everything concerning chemical warfare, as well for offensive as for defensive purposes, organization and training of personnel, supply and conduct of operations.

One regiment, called Ist Gas Regiment (formerly 3oth Regiment of Engineers) was organized. It comprised: 


\section{The American Army in the European Conflict}

8 headquarters,

2 Stokes companies,

4 Cylinder and Livens projector companies.

It was later increased to six battalions each of three companies.

On March 5, 1918, the chemical warfare service, the headquarters of which were then at Tours, was reorganized into three main divisions:

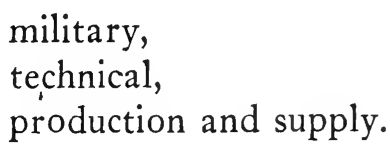

On June 3, I9 I 8, considering the ever-growing importance of chemical warfare, General Pershing recommended to his government that a special service intended for this kind of war be established in the National Army. On June 28th the War Department authorized the organization of the "Chemical Warfare Service." The gas service of the Expeditionary Forces became the overseas division of the new formation, with a total authorized strength of 91 6 officers and 7,624 enlisted men, and was increased on October 8, I9I8, to I,3 I 5 officers and I 7,205 enlisted men. The war came to an end before the latter increase had been realized.

Two general orders dated May 27, and July 2, I9I8, organized the details of the operations of the chemical warfare service in the A. E. F. Army, army corps, and divisions; gas officers were to be appointed by the chief of the service.

Regimental and battalion gas officers were to be chosen by the unit commanders among those having followed special courses instituted at the gas school. 
The chief of chemical warfare procured material either through requests made from the other services (quartermaster and ordnance) through requisition from the United States, or through purchase in Europe.

He had representatives in the general purchasing board and on the inter-allied committee for chemical warfare supplies organized on March 6, I9 I8.

Important deliveries of gas masks (mark $M 2$ ) were made by France; 400,000 respirator boxes were purchased in Great Britain.

Supplies were stored in central depots, ${ }^{28}$ whence, according to requisitions made by regulating officers, they were forwarded to army depots established in the zone of field operations. At the time of the armistice these central depots had on hand, among other items, I, 850 ,ooo respirator boxes, 4,095 projectors, 36,468 Livens cylinders, and 39, I05 Stokes trench-mortar bombs filled with aquinite and Collongite.

Manufactures organized in Europe by the American service of chemical warfare were not yet greatly developed at the end of the war: 2,00o cylinders were filled with gas at Pont-de-Claix: a mask salvage plant was in operation at Chateauroux, 200,000 Connell canisters had been produced in England.

As for shells, bombs, and grenades, the service limited its activities to the supply of gas envelopes; that is to say, the projectiles themselves being supplied by the ordnance. Twenty per cent. of all projectiles that were being produced in the United States at the close of hostilities, up to and including, $220 \mathrm{~mm}$. shells were filled with gas. This proportion was to be increased to 25 per cent. after January I, I9I9.

28 The most important of these were established at Montoir, St. Sulpice, and Gièvres. 


\section{The American Army in the European Conflict}

A chemical laboratory for the study of technical problems was established at Puteaux. Sag paste, an excellent preventative for mustard gas burns, was turned out there.

Near Chaumont, the service had at its disposal an experimental field for the tests pertaining to allied or enemy chemical warfare material.

A school for officers was annexed to it; the course, which was of varied duration, was at the time of the armistice being followed by 228 officers.

American gas troops took a most active part in the great military operations that developed between June, I 9 I 8 , and the armistice.

On the Marne and the Vesle from June 3oth to September I 8 th, they utilized among others, 229 Stokes thermit bombs, 7I 8 smoke bombs, and executed eight important gas projector attacks.

During the Meuse-Argonne offensive, six companies of the Ist Gas Regiment were assigned to the First Army, and organized into three battalions. They employed I, I 85 Stokes smoke bombs, I, 345 Thermit bombs, 489 gas bombs, 236 Livens cylinders, 130 of which were filled with gas and 206 with high explosives. As the attacks progressed, more and more gas was used, the confidence of attacking troops in the units of the gas service was constantly proved by the requests sent in ever-increasing numbers for the collaboration of the personnel of the gas service in their attacks.

More cannot be said in proof of the value of this service and the skill and courage of its personnel.

The inspector-general's department is a very ancient institution in the United States Army, having been organized in 1775 under General Washington. 
Its sphere of activity extends over every branch of military affairs excepting purely tactical operations.

According to existing regulations, inspectors exercised a comprehensive and general observation over all that pertains to the efficiency of the army: camps, billets, transportation, clothing, armament and equipment, accounts, supplies, morale of the troops. They condemn unserviceable property, verify money accounts, expenditure of public funds, and report as to irregularities discovered, making suggestions as to the correction of defects coming under their observation. They also undertake special investigations when required.

It is easy to conceive of the importance of the part played by such a department in an organization of the size of the Expeditionary Forces whose activities covered so many points of our territory. Therefore, twice in succession, General Pershing was led to increase the scope of these activities.

On November 9, I9I7, he authorized the inspectorgeneral to give all orders which might be found necessary to secure prompt correction of any irregularities or deficiencies noted at inspection of troops. On June 5, I9 I 8, when the American Army entered the period of active operations on a large scale, he charged the inspector general with the supervision of discipline throughout the American Expeditionary Forces.

In the course of the great offensive which marked the ultimate phase of the war, the inspector generals were to keep the high command constantly informed touching the fighting value of the troops at the time when they entered the field of battle or were withdrawn from the fight.

The department was during the entire course of the 


\section{The American Army in the European Conflict}

war commanded by General Brewster; it was organized by army, army corps, and division.

Divisional inspectors were to keep in touch with troops engaged in line; thus they reported only upon such facts as they had personally observed, and their daily reports kept the high command most exactly informed as to the material and moral conditions of the troop and their leaders.

In the American Army, the activities of the judgeadvocate are very much the same as those of the "Service du Contentieux et de la Justice Militaire" in the French Army.

General Bethel, who was at the head of this department during the whole war, organized his central office at Chaumont in five sections. The first considered general questions of military law and administration, the application of war legislation, matters of naturalization, and repatriation. It supplied private and gratuitous legal advice to members of the Expeditionary Forces. The second section supervised the work of the field judgeadvocates, reviewed the proceedings of general courtsmartial, and sat upon disciplinary questions and those connected with the administration of military justice.

The third section was concerned solely with those cases of conviction by military courts which involved the penalties of dishonorable discharge, the dismissal of an officer, or death.

The fourth section was concerned with the legal aspects of army finance, with questions of purchase and supply, contracts, accounts, claims, pay and allowances, insurance, and workmen's compensation.

The fifth section studied and advised upon questions 
of international law, the interpretation of treaties and international agreements, matters of foreign law, of relations with the Allies and the enemy, prisoners of war, and the military occupation.

With troops in the field, each army had its army judgeadvocate, each corps a corps judge-advocate, and each division normally two judge-advocates.

In the zone of the interior, there was a judge-advocate of the S. O. S. stationed at Tours, under whom operated judge-advocates for each of the sections of the S. O. S. $\mathrm{He}$ was also the director of the renting, requisitions, and claims service.

Before terminating this chapter it may be of interest to point out two important features of the administration of military justice by American courts-martial. The first consists in the power wielded by the authority which prescribed the reunion of a court-martial to modify, but only in a mitigating sense, any sentence that does not involve death penalty or dismissal from the army.

The other one involves the very frequent application of suspension of pay, this kind of punishment being very effective by reason of the high pay rates in the American Army.

In order to complete this summary description of the main administrative departments existing in the A. E. F. at the close of hostilities, three more ought to be mentioned here:

The Military Board of Allied Supply, the General Direction of transportation, and the motor transport service.

But the first of these, by reason of its regional activities, was very closely linked to the territorial organiza- 
246 The American Army in the European Conflict

tion of the service of supplies. The second whose main duty consisted in connecting the advance section, the intermediate section, and the base section, had its activities spread all along the American lines of communication. The third, forming as it did the complement and prolongation of the service of railways, naturally falls under the subject of this latter treated elsewhere and consequently these three branches are grouped together in Chapter XI under the heading, "Development of the Lines of Communication." 


\section{CHAPTER VII}

SITUATION OF THE EXPEDITIONARY FORCES AT THE BEGINNING OF SEPTEMBER, I 9 I 8

DURING the first days of September, General Pershing found himself at the head of an army of I,400,000 of whom I,000,000 at least were combatants.

But if we wish to form a real idea of the strength of the Expeditionary Forces at this time, these numbers require careful commentary. For, as may be easily understood, the commander-in-chief could only dispose in the active offensive operations, imminent at this date, of those units already organized and sufficiently trained.

Should the war be prolonged, the number of divisions would, of course, constantly increase. The arrival of troops was being effectuated practically without either delay or serious hindrance. Thanks to the application of the system of replacements which had been adopted, no great diminution in the strength of the fighting units could be foreseen. It was easy for General Pershing to establish with relative accuracy, after the following manner, the exact military situation of his forces. To those divisions which, after having already fought, were withdrawn from the line in order to rest and incorporate the replacements automatically furnished by the divisional depots, were to be added those divisions not yet engaged but whose training was or was about to be terminated. General Pershing had also to take into account the actual position of his troops and their employment either in the 


\section{The American Army in the European Conflict}

rear or in the advance zone. This situation, such as it appeared in the early days of September, we shall endeavor to place before the reader.

On the twenty-second of August, at which time the commander-in-chief contemplated forming a purely American Field Army composed of his First and Third Corps, placed side by side upon the Vesle, the army headquarters were established at La Ferté-sous-Jouarre, thence transported to Neufchâteau, where they awaited the occasion to direct the operations which were to be attempted by the American troops.

- As yet no one had been designated to take command of the first field army, and this, for reasons which may easily be explained: up to this time, the numerous activities in which American troops had been engaged were carried on with units which, in size, were never superior to a division or at most a corps. No American chief had, as yet, been obliged to grapple with the difficulties and complications entailed by a command over a very extensive front, where obstacles to communication and supply in a foreign land were added to all those inherent to active combat.

The situation was particularly delicate for the first American army chief who should be called unon to face it, especially as the French Government had asked and obtained from America, at the moment of the spring offensive, the placing of infantry transport at the head of the priority schedule, to the detriment of any other arm or service. The difficulties and responsibilities of the chief of the first field army, thus deprived of part of the resources necessary for the life of an army, were bound to be very great. General Pershing considered 


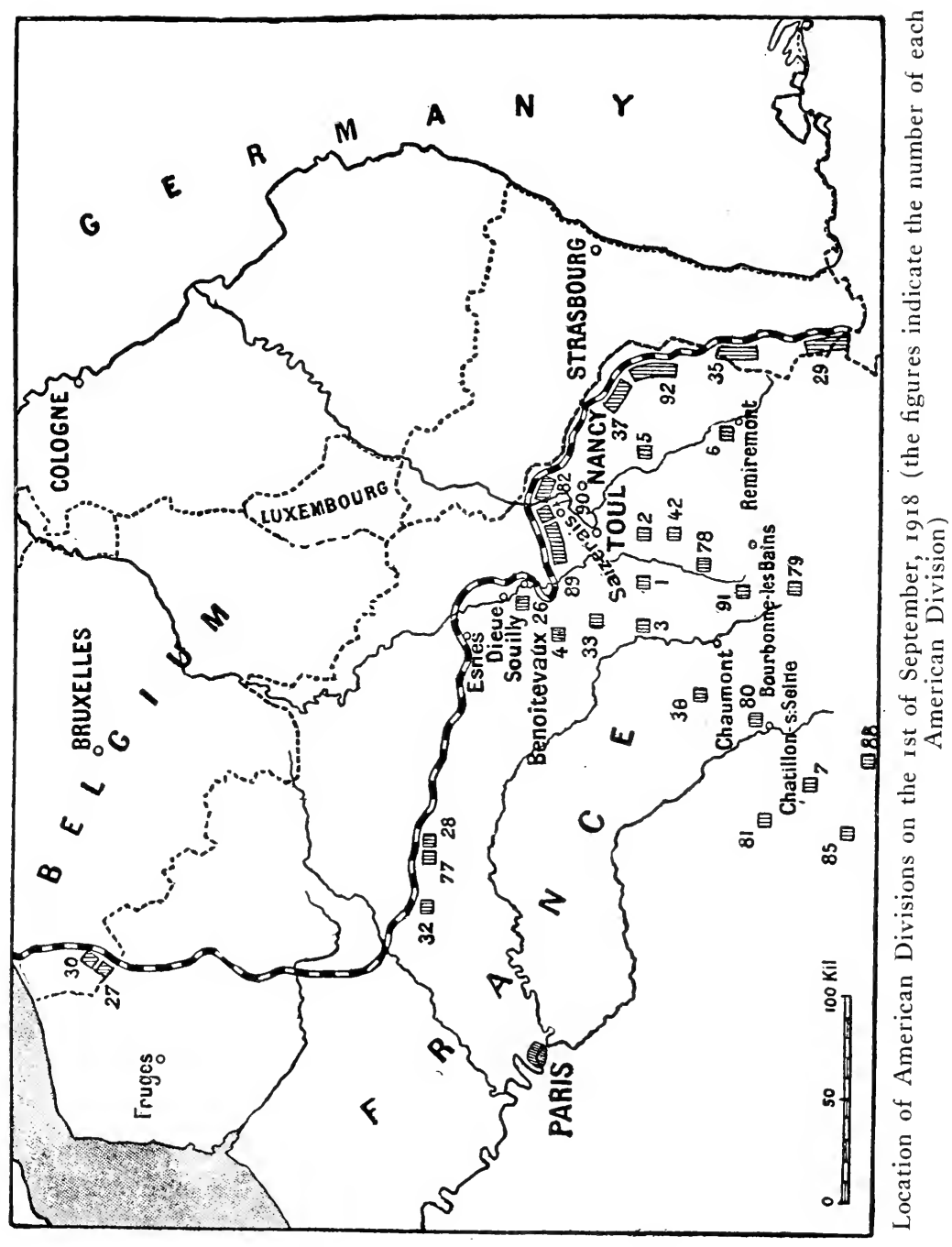



that he alone should assume such an onerous burden, and reserved to himself the direct command of the first American Army which was now to take the field. ${ }^{1}$

Already seven army corps existed or were in process of formation:

The First Corps, under General Liggett, which had already taken part in active operations in the Marne and Vesle campaigns, and was at this time between Saizerais and Toul. This corps possessed its organic artillery and a portion of its services of the rear.

The Second Corps may be simply noted here as operating upon the British front. General Read, who was in command, had established his headquarters at Fruges where he administered the American divisions which were in line or else undergoing instruction in the British zone.

The Third Corps, commanded by General Bullard, still remained at Château-de-Fresnes, south of the Vesle, from whence they were soon to be transported to Souilly, near Verdun. Like the First, the Third Corps had already been proven; like it it also possessed its own artillery and other services, and might therefore be considered as ready for action.

The Fourth Corps of much more recent formation was under the orders of General Dickman, former commander of the Third Division; his staff was newly as-

1 Order of Battle of the First Army at the date of September I, I918.

General John J. Pershing, Army Commander

Colonel Hugh. A. Drumm............ Chief of Staff

Colonel A. B. Barber............... Chief of the First Section

Colonel Charles L. Hall.............. Chief of the Second Section

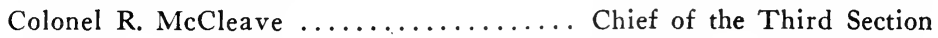

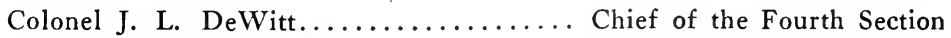

Colonel Lewis H. Watkins........... Chief of the Fifth Section 
sembled at Toul with supervision over operations in the southern Woevre sector. ${ }^{2}$

The Fifth Corps had been for several days at BenoiteVaux, near Dieue-sur-Meuse. Its chief, General Cameron, lately at the head of the Fourth Division, during operations between the Marne and Vesle, had but recently constituted his staff. ${ }^{3}$

The Sixth Corps which was at Bourbonne-les-Bains recently organized and consequently not ready for action. It was commanded by General Bundy, lately at the head of the gallant Second Division which had checked the enemy before Château-Thierry. ${ }^{4}$

The Seventh Corps was operating in the Vosges under General Wright, formerly commanding the Fifth Corps, with headquarters at Remiremont. This Seventh Corps

2 Order of Battle of the Fourth Army Corps at the date of September I, 19 I8.

Major-General Joseph T. Dickman, Commanding the Army Corps Colonel Stuart Heintzelman........... Chief of Staff

Major James Ulio............... Chief of First Section, G r

Major Joseph Stillwell............. Chief of Second Section, G 2 Lieutenant-Colonel W. H. Haskell........ Chief of Third Section, G 3

3 Order of Battle of the Fifth Army Corps at the date of September r, 1918 .

Major-General George H. Cameron, Commanding the Army Corps Brigadier-General W. B. Burtt......... Chief of Staff Lieutenant-Colonel Albert W. Forman..... Chief of First Section, G I Lieutenant-Colonel George M. Russell.... Chief of Second Section, G 2 Lieutenant-Colonel T. H. Emerson....... Chief of Third Section, G 3

4 Order of Battle of the Sixth Army Corps at the date of September I, 19 I 8 .

Major-General Omar Bundy, Commanding the Army Corps

Brigadier-General Briant H. Wells........ Chief of Staff

Colonel Charles H. Bridges............. Chief of First Section, G I

Lieutenant-Colonel S. T. Mackall........ Chief of Second Section, G 2 Colonel George F. Baltzell............ Chief of Third Section, G 3 
was formed from elements of the old Fifth Corps whose place it took. ${ }^{5}$

General Wright's administrative supervision extended over all the American forces under instruction or occupying sectors in the rear of the French eastern group of armies.

In fine, out of seven army-corps staffs, we may consider that two were immobilized - the Second upon the British front; the Seventh on the front of our eastern group of armies - and the Sixth was not, for the moment, capable of being utilized. Consequently, we cannot count it at this time, more than four army corps ready for active service upon the Lorraine Front; namely, the First, Third, Fourth, and Fifth.

Among the divisions which could be considered at this time as fighting units; that is to say, which had participated in action or occupied the trenches for a sufficient period to have become accustomed to being under fire, and which had also the advantage of possessing their own artillery services, fourteen could be counted upon in the action which was shortly to take place.

Three on the Vesle, where they formed part of the Third American Army Corps, the Twenty-eighth, Thirtysecond, and Seventy-seventh.

Three in defensive sectors in the southern Woevre

5 Order of Battle of the Seventh Army Corps at the date of September I, 1918 .

Major-General William W. Wright, Commanding the Army Corps Lieutenant-Colonel Gordon Johnson ...... Chief of Staff

Lieutenant-Colonel Ward S. Dabney..... Chief of First Section, G I First Lieutenant James W. Barney........ Chief of Second Section, G 2 Captain John H. Prentice............ Chief of Third Section, $\mathrm{G}_{3}$ 
region north of Nancy: the Eighty-second, ${ }^{6}$ Eighty-ninth, ${ }^{7}$ and Ninetieth; ${ }^{8}$ only the first of these possessed its artillery. But in order to hasten the entry of the two lat-

${ }^{6}$ Order of Battle of the Eighty-second Division at the date of September I, 1918.

Major-General William P. Burnham, Commanding the Division 163d Infantry Brigade I64th Infantry Brigade Brigadier-General M. D. Cronin Brigadier-General J. R. Lindsey 325th Infantry Regiment

Colonel Walter M. Whitman 326th Infantry Regiment Colonel John C. McArthur 327th Infantry Regiment Colonel Frank D. Ely 328th Infantry Regiment Colonel H. B. Nelson

157th Artillery Brigade Brigadier-General C. D. Rhodes

319th Artillery Regiment Colonel E. d'A Pearce 32oth Artillery Regiment Colonel H. C. Williams 32 Ist Artillery Regiment Colonel Clarence Deems, Jr.

7 Order of Battle of the Eighty-ninth Division at the date of September I, 1918.

Brigadier-General Frank L. Winn, Commanding the Division (This division had not yet received its artillery).

I77th Infantry Brigade

Colonel James H. Reeves

353d Infantry Regiment

Colonel Conrad S. Babcock

354th Infantry Regiment

Colonel Americus Mitchell 178th Infantry Brigade Brigadier-General T. G. Hanson 355th Infantry Regiment Colonel James D. Taylor 356th Infantry Regiment Colonel L. M. Nuttman

8 Order of Battle of the Ninetieth Division at the date of September I, 1918 .

Major-General Henry T. Allen, Commanding the Division (This division had not yet received its artillery).

I7gth Infantry Brigade

Brigadier-General J. P. O'Neil

357th Infantry Regiment

Colonel Ed. T. Hartman

368th Infantry Regiment

Colonel E. M. Leary
I8oth Infantry Brigade Brig.-Gen. V. S. McAlexander 359th Infantry Regiment Colonel W. A. Cavanaugh 36oth Infantry Regimert Colonel H. C. Price 
ter into line, the organic artillery destined for the American divisions operating with the British could be assigned to these units.

Eight withdrawn from the front for rest and instruction had taken part in the operations of July and August or had been engaged in active sectors. These included the First, Second, Third, Fourth, and Fifth, ${ }^{9}$ the Twentysixth, Thirty-fifth, ${ }^{10}$ and Forty-second.

${ }^{9}$ Order of Battle of the Fifth Division at the date of September I, I9r8.

Major-General John McMahon, Commanding the Division

oth Infantry Brigade

Brigadier-General J. C. Castner

5oth Infantry Regiment

Colonel F. B. Hawkins

6rst Infantry Regiment

Colonel Hugh D. Wise
Ioth Infantry Brigade

Colonel Paul B. Malone

6th Infantry Regiment

Colonel Henry J. Hunt

IIth Infantry Regiment

5th Artillery Brigade

Colonel John B. Bennet

Brigadier-General C. A. F. Flagler

Ioth Artillery Regiment

Lieutenant-Colonel C. P. Hollingsworth

2oth Artillery Regiment

Colonel Brooke Payne

21st Artillery Regiment

Colonel H. MacMaster

10 Order of Battle of the Thirty-fifth Division at the date of September I, 1918 .

Major-General Peter E. Traub, Commanding the Division

$\begin{array}{cc}\text { 6oth Infantry Brigade } & \text { 7oth Infantry Brigade } \\ \text { Brigadier-General N. F. McClure } & \text { Brigadier-General Chas. I. Martin }\end{array}$

I37th Infantry Regiment

Colonel Clad. Hamilton

I38th Infantry Regiment

Colonel George P. White 6oth Artillery Brigade

I3oth Infantry Regiment

Colonel Kirby Walker

I 4oth Infantry Regiment

Colonel Pierce A. Murphy

Brigadier-General L. G. Berry

I28th Artillery Regiment

Colonel F. M. Rumbold

I2gth Artillery Regiment

Colonel Karl D. Klemm

I3oth Artillery Regiment

Lieutenant-Colonel James E. Wilson 
Four divisions more were placed on the Vosges front either framed in with French troops or brigaded with French divisions. They were the Thirty-seventh, ${ }^{11}$ Ninety-second, ${ }^{12}$ Sixth, ${ }^{13}$ and Twenty-ninth.

The Thirty-seventh and the Sixth expected to receive their artillery in the middle of September, whereas that

11 Order of Battle of the Thirty-seventh Division at the date of September r, r918.

Major-General C. S. Farnsworth, Commanding the Division

(This division had not yet received its artillery).

73 d Infantry Brigade

Brig-Gen. C. X. Zimmerman

145th Infantry Regiment

Colonel Sanford B. Haubery

I 46 th Infantry Regiment

Colonel James N. Pickering 74th Infantry Brigade Brigadier-General W. P. Jackson

I47th Infantry Regiment

Colonel F. W. Galbraith

148th Infantry Regiment

Colonel J. A. Lynch

12 Order of Battle of the Ninety-second Division at the date of September I, 1918 .

Major-General Charles C. Ballou, Commanding the Division (This division had not yet received its artillery).

I $\delta_{3}$ d Infantry Brigade

Brigadier-General M. H. Barnum

365 th Infantry Regiment

Colonel V. A. Caldwell

366th Infantry Regiment

Colonel Ralph B. Parrott 184th Infantry Brigade Brigadier-General Wm. H. Hay

367th Infantry Regiment

Colonel James A. Moss

368th Infantry Regiment

Colonel Fred R. Brown

13 Order of Battle of the Sixth Division at the date of September I, $19 \times 8$.

Major-General Walter H. Gordon, Commanding the Division

(This division had not yet received its artillery).

IIth Infantry Brigade

Brigadier-General Wm. R. Dashiell Brigadier-General James B. Erwin

51st Infantry Regiment

Colonel Isaac Newell

52d Infantry Regiment

Colonel Ernest V. Smith 12th Infantry Brigade

53d Infantry Regiment

Colonel F. G. Stretzinger

54th Infantry Regiment

Colonel M. Crowley 


\section{American Effectives in September, I9I8 255}

of the Twenty-ninth ${ }^{14}$ was only to be furnished at the end of the month.

As to the five divisions distributed in the British zone, two - the Twenty-seventh and the Thirtieth - were engaged in active operations, after which, regrouped and reorganized, they were to constitute the Second Corps when this was to operate with the British. The Thirtythird, ${ }^{15}$ Seventy-eighth, ${ }^{16}$ and Eightieth having practically

${ }^{14}$ Order of Battle of the Twenty-ninth Division at the date of September I, 1918 .

Major-General Charles G. Morton, Commanding the Division (This division had not yet received its artillery).

57th Infantry Brigade

Colonel Milton A. Reckord

II3th Infantry Regiment

Colonel Harry C. Jones

IIfth Infantry Regiment

Lieutenant-Colonel G. M. Buttle 58th Infantry Brigade

Brigadier-General H. H. Bandholtz

115th Infantry Regiment

Lieutenant-Colonel Wm. R. Pope

IIbth Infantry Regiment

Colonel A. J. Harris I, 1918 .

15 Order of Battle of the Thirty-third Division at the date of September

Major-General George Bell, Commanding the Division

('This division had not yet received its artillery).

65 th Infantry Brigade

Brigadier-General Edw. L. King

I2oth Infantry Regiment

Colonel E. A. Myer

roth Infantry Regiment

Colonel J. V. Clinnin 66th Infantry Brigade Brigadier-General Paul A. Wolf I3Ist Infantry Regiment Colonel Joseph B. Sanborn I32d Infantry Regiment Colonel Abel Davis

${ }^{16}$ Order of Battle of the Seventy-eighth Division at the date of September I, I9I8.

Major-General James H. McCrae, Commanding the Division (This division had not yet received its artillery).

I55th Infantry Brigade
Brigadier-General Mark L. Harsey 3ooth Infantry

Colonel John M. Morgan 3roth Infantry Regiment

Colonel Walter C. Babcock
3IIth Infantry Regiment

Colonel Marcus B. Stokes 312th Infantry Regiment Colonel Alvord V. P. Anderson 


\section{The American Army in the European Conflict}

completed their training were ready to be withdrawn from the British zone and sent to rejoin the bulk of the American contingents at the French front, should General Pershing think fit. Accordingly at the end of August orders were given to that effect.

The Thirty-third was sent near Esnes (in the Verdun district), the Seventy-eighth to Bourbonne-les-Bains, the Eightieth ${ }^{17}$ to Chatillon-sur-Seine.

One colored division (the Ninety-third) was split up and distributed among the French forces, a regiment or two by division. ${ }^{18}$

The six depot divisions were to serve as a reservoir to be drawn upon for filling up the ranks of the fighting units, and need simply be noted here; they were the Thirty-ninth, Fortieth, Forty-first, Seventy-sixth, Eightythird, and Eighty-fifth.

Six more divisions recently disembarked had just begun training; these were the Ninety-first, ${ }^{19}$ Seventy-

17 Order of Battle of the Eightieth Division at the date of September I, 19 r8.

Major-General Adelbert Cronkhite, Commanding the Division (This division had not yet received its artillery).

\section{I5oth Infantry Brigade}

Brig.-Gen. George H. Jamerson

3I7th Infantry Regiment

Colonel Howard R. Perry

318th Infantry Regiment

Colonel Ulysses G. Worillow
I6oth Infantry Brigade

Brigadier-General Lloyd M. Brett 3Igth Infantry Regiment Colonel Frank S. Cochon 32oth Infantry Regiment Lt.-Col. Ephraim G. Peyton

18 The 369th Infantry reënforced the French One hundred Sixty-first Division; the 370 th the French Fifty-ninth Division; the 37 Ist and $372 \mathrm{~d}$ reinforced the One hundred Fifty-seventh French Division.

19 Order of Battle of the Ninety-first Division at the date of September I, 19 r8.

Major-General William H. Johnston, Commanding the Division

(This division had not yet received its artillery).

I8Ist Infantry Brigade

Brigadier-General J. B. McDonald
I82d Infantry Brigade

Brigadier-General F. S. Foltz 
ninth, ${ }^{20}$ Thirty-sixth, ${ }^{21}$ Seventh, ${ }^{22}$ Eighty-first, ${ }^{23}$ and Eighty-eighth. ${ }^{24}$

The Ninety-first was expected to be ready in mid-September, and capable, if General Pershing so decided, to go directly into line without passing through that preparatory school of combat, the quiet sector.

36Ist Infantry Regiment

Colonel Wm. D. Davis

36ad Infantry Regiment

Lt.-Col. J. B. Woolnough 36зd Infantry Regiment

Colonel H. LaT. Cavanaugh 36th Infantry Regiment

Colonel Geo. MacD. Weeks

${ }^{20}$ Order of Battle of the Seventy-ninth Division at the date of September I, 1918 .

Major-General Joseph E. Kuhn, Commanding the Division (This division had not yet received its artillery).

I57th Infantry Brigade

Brig.-Gen. Wm. J. Nicholson

313th Infantry Regiment

Colonel Claude B. Sweezey

3I4th Infantry Regiment

Colonel Wm. H. Oury 158th Infantry Brigade

Brigadier-General K. H. Noble

315th Infantry Regiment

Colonel Alden C. Knowles

316th Infantry Regiment

Colonel Oscar J. Charles

21 Order of Battle of the Thirty-sixth Division at the date of September I, 1918 .

Major-General William R. Smith, Commanding the Division (This division had not yet received its artillery).

7Ist Infantry Brigade

Brig.-Gen. Pegram Witworth

I4Ist Infantry Regiment

Colonel W. E. Jackson

142d Infantry Regiment

Colonel A. W. Bloor 7and Infantry Brigade Brigadier-General John A. Halen

143d Infantry Regiment

Colonel John S. Hoover

r44th Infantry Regiment

Colonel Wm. K. Wright

22 Order of Battle of the Seventh Division at the date of September I, 1918 .

Brigadier-General C. H. Barth, Commanding the Division

(This division had not yet received its artillery).

I3th Infantry Brigade

Brigadier-General C. H. Barth

55th Infantry Regiment

Colonel J. V. Heidt

56th Infantry Regiment

Colonel W. O. Johnson
I4th Infantry Brigade

Brigadier-General Lutz Wahl

34th Infantry Regiment

Colonel Fred. L. Munson

67th Infantry Regiment

Colonel E. A. Lewis 
The Seventy-ninth could be expected to undertake active operations at about the same time.

The Thirty-sixth had arrived in France only in the last days of July and could hardly be ready for active service before October. The three other divisions which figure in this enumeration - that is to say, the Seventh, Eighty-first and Eighty-eighth - were only sent into camp at about the middle of August and could not be counted on before the latter part of October.

To sum up the situation: General Pershing might count upon having at the end of August, ready for active service, one field army staff, four army corps staffs, fourteen divisions able, in case of necessity, to take the field. These divisions possessed their artillery. Four divisions might, in case of emergency, also take part in the battle since they already were in sectors and were expecting to

23 Order of Battle of the Eighty-first Division at the date of September I, 1918 .

Major-General Charles J. Bailey, Commanding the Division (This division had not yet received its artillery).

I6Ist Infantry Brigade I6zd Infantry Brigade Brigadier-General G. W. McIver

32Ist Infantry Regiment

Col. Frank Halstead 322d Infantry Brigade

Colonel L. T. Richardson Brigadier-General M. McFarland 323d Infantry Regiment Colonel Thomas A. Pearce 324th Infantry Regiment Colonel G. W. Moses

24 Order of Battle of the Eighty-eighth Division at the date of September I, 1918 .

Major-General William Weigel, Commanding the Division

(This division had not yet received its artillery).

175th Infantry Brigade Brigadier-General M. B. Stewart 349th Infantry Regiment Colonel G. Sturdevant 35oth Infantry Regiment

Colonel H. J. Price
I76th Infantry Brigade Brigadier-General W. O. Beach 35Ist Infantry Regiment Colonel H. B. Crosby 352d Infantry Regiment Colonel Clyde E. Hawkins 
be joined by their artillery before the end of September. Three divisions might be transferred from the British front and two more, whose instruction was almost finished (the Ninety-first and Seventy-ninth) could be considered as utilizable in case of necessity.

The following month, four fresh divisions might be expected to leave camp for the fighting line; consequently America could calculate on placing 600,000 combatants in the field during the first days of September, I Oo,000 more at the end of this same month or, at the latest, during October.

In order to complete this enumeration, we should also say a word on the situation of the artillery in the American Army.

At the date of which we are speaking, fifteen brigades - that is to say, the organic formations of fifteen divisions - had quitted their training camps and were ready to support their infantry in battle. By modifying the ultimate designation of some of these units - as was done in certain divisional formations, and reënforcing the divisions ready for combat on the French front with certain artillery brigades which had been destined to divisions operating on the British front, or with those whose divisions were not scheduled to participate in the forthcoming battle, it was found possible to bring into line for the great offensive which General Pershing was about to undertake almost the total artillery forces of which the American Army at this time disposed.

During the month of September, nine more divisional artilleries might be expected to quit camp, after their first phase of training, if they were able to find the requisite number of horses, and, during the month of October, three more brigades might be counted upon. 


\section{The American Army in the European Conflict}

The heavy artillery of the American forces which was sufficiently trained to enter the field comprehended seven regiments, of which four were armed with the long 155 G. P. F.; two with the 8-inch Anglo-American guns, and one with the British 9.2 inch guns.

The railroad artillery which was now also in readiness was constituted by one entire regiment and a portion of two others.

Taken together, all the above-mentioned units staffs, divisions, infantry, or artillery regiments - might be said to share in the same qualities and possess the same defects.

Eager for combat, sufficiently instructed, and absolutely decided to win, their equipment was necessarily inadequate. They lacked horses, transport wagons, trucks, ambulances, all the rolling stock, in short, and those accessories which, in previous wars, were found cumbersome to the fighting units, but which were now essential in the kind of warfare which the Americans were about to carry on.

The larger the unit, the more it must necessarily suffer from a shortage such as we have mentioned. The division better able to suffice to itself could, when it was possible to reënforce it with a fraction of French artillery, superposed upon the groupings of the American batteries, sustain a lengthy action. But in the army corps the nondivisional elements found themselves in a much more precarious position and in the First Army the same difficult situation was to be found as has been noticed in the army corps, only more aggravated.

The commander-in-chief of the Expeditionary Forces found himself therefore face to face with a condition of 


\section{American Effectives in September, $1918 \quad 26 \mathrm{I}$}

things resulting from the early decisions which had been taken under the stress of circumstances made necessary by the military happenings of the spring of I9I8. At which time, as we have seen, the French and British authorities requested the American Government to hasten the transport of infantry troops to the detriment of any other form of service. The lack of horses was now felt to an alarming degree. The United States had held over those which were ready to be embarked and France was no longer able, by requisition, to furnish the necessary number.

Thus it is easy to understand - and upon this remark we may terminate this chapter - the American Expeditionary Forces disposed of a splendid offensive instrument in the early days of September, but one which lacked, if it were to give its full measure of success, certain essential organs, and the larger the unit the more this want was felt. This condition of things was particularly aggravated in the army corps and in the field army. 


\section{CHAPTER VIII}

THE AMERICAN ARMY DURING THE GENERAL OFFENSIVE - SEPTEMBER-NOVEMBER, I9I8. (BATTLE OF ST. MIHIEL - OPERATIONS BETWEEN MEUSE AND ARGONNE)

From the time the Sixth French Army reached the Vesle, the enemy made manifest his intention of clinging to his positions on the right bank of this river, and it soon became evident that the Franco-American troops under General Degoutte would have to mark time for a certain period on this part of the front.

Although the American commander-in-chief had expected personally to take over the direction of the army in this sector, thereby relieving the French Sixth Army by a fresh allied contingent; in view of the circumstances which indicated a let-up of active operations hereabout and a tendency toward stabilization, his attention was naturally turned elsewhere, and, since the foe intended holding firmly to his center it became clear that good strategy on our side demanded a maneuver on the wings.

General Pershing naturally turned toward the St. Mihiel salient.

For more than a year, a plan affecting this section of the front had been projected by the Chaumont headquarters, studied and discussed between the French and American commanders, and even touched upon during the 262 
second interview between Generals Pétain and Pershing at Compiègne in June, I9I7. The idea was therefore by no means a new one.

It now presented a triple advantage: that of extending the front of our attack; that of giving an appropriate objective to the American troops of whom many were still inexperienced, and finally, to turn the bulk of the Expeditionary Forces into a portion of the front which was in direct line with its communications by road and rail, which covered its depots, its training camps; in short, which was in close touch with the various centers of American activity.

All these points being in its favor, the plan encountered unanimous support; it remained merely with the high command to arrange the details and fix the day for the great assault.

Marshal Foch, who wished to give the enemy a minimum time to recuperate from the effects of the blows already dealt him in other theaters, desired that the attack on the St. Mihiel salient might be undertaken as soon as practicable.

General Pétain and General Pershing shared these views, more especially as the autumnal rainy season was near at hand when the plains of the Woevre, the scene of future maneuvers, would be transformed into a vast swamp unfavorable to troop movements.

As to the possible extension which ought to be given to this affair, opinions differed somewhat.

The American general contemplated lining up his forces on the southern Woevre front east of St. Mihiel and on the Meuse Heights north of St. Mihiel, debouching from these two separate starting points and seizing afterward by a surprise attack - his two masses united - the 


\section{The American Army in the European Conflict}

second German position known as the Hindenburg Line. Thus he would find himself in a position to threaten not only the mineral basin of Briey, but also the adversary's communication lines in this neighborhood.

The French high command considered limiting the offensive action to the taking of the Hindenburg Line.

The allied high command reduced the plan in order to take in less distant objectives. Marshal Foch did not wish to see the American Army engaged too far in a direction so divergent from that on which he intended action, as he soon might have need of the coöperation of American troops at another point. ${ }^{1}$

The prerogatives appertaining to each individual commander during these operations arranged themselves as a matter of course. Thanks to the attitude of General Pershing and his devotion to the greater good of the cause, all minor difficulties were smoothed away. In the same spirit which had caused him to accept a command under General Fayolle when he was to direct limited operations on the Vesle front, he now willingly placed himself under the orders of the commander-in-chief of the French armies. From the first days of September a most close and intimate coöperation between General Pétain and General Pershing was established. All decisions were rapidly taken and in complete accord.

Following is an enumeration of some of the arrangements made to facilitate the heavy task imposed upon the American commander-in-chief who, at this moment, was obliged not only to elaborate and to execute the plans under contemplation, but also to create an entire army,

${ }^{1}$ Already on the second of September, Marshal Foch had confided to General Pershing his intention of including the American forces in his projected offensive between Verdun and Rheims. 
improvise its staff and services, and that during the lapse of one month's time.

One French officer was charged with the liaison between Generals Pershing and Pétain in order to expedite the solution of the many questions which constantly arose.

The eastern group of armies, and more especially the Eighth French Army, were to furnish the services - rear and supplies - which were lacking to the American forces operating in the Woevre.

In the same manner, the Second French Army was to furnish what was essential to the American contingents operating on the Meuse Heights in the vicinity of Les Eparges and Combres.

The Second Colonial Corps, maintained at a strength of three divisions, was to remain posted before St. Mihiel in order to link the two American attacks which were scheduled for the same day.

A fourth French division was also placed under General Pershing's orders to take part in the offensive near Les Eparges.

Still more French effectives were turned over to the Americans on this occasion.

580 French $75 \mathrm{~mm}$. guns,

793 heavy cannons and mortars of various calibers,

I 82 trench mortars,

273 tanks, $^{2}$

192 airplanes.

Added to these, we may reckon the independent aerrial division which operated with the Americans during the action of September I 2 th. $^{3}$

2 Thirty-four Schneider, thirty-six St. Chamond, and the rest Renaults.

The American Army disposed of 144 Renault tanks manned by their own crews.

3 The aërial division included 550 airplanes. The American aviation 


\section{The American Army in the European Conflict}

General Pershing was also authorized to employ a considerable number of automobile trucks which were held in reserve near Toul and Bar-le-Duc. ${ }^{4}$

With these resources added to those of the American Army, General Pershing was enabled to mount a powerful offensive; he could dispose of four French divisions, twelve American divisions, 2,900 guns.

The operations were to be kept extremely secret. The commander-in-chief had concealed his departure from La Ferté-sous-Jouarre and had not allowed his change of intention concerning his taking over the command on the Vesle to be known. Rumors were spread tending to indicate that the Americans were preparing important concentrations in High Alsace, near Belfort. General Pershing had chosen Ligny-en-Barrois as his own headquarters, but he installed temporarily his chief of staff, General Drumm, at Neufchâteau with all his services, and, in order to give weight to these fictitious maneuvers, he made frequent appearances at Chaumont and was also seen in the Vosges.

Equal care was taken to mask the heavy troop concentrations which were being executed around the St. Mihiel salient. The nearer they approached, the greater were the precautions taken. Infantry and artillery columns marched by night. In the daytime, men, horses, and material were concealed in the woods.

On August 3oth, General Pershing took command of the First American Army sector, extending over fifty miles from Port-sur-Seille, on the right bank of the Moselle, to Châtillon-sous-les-Côtes, near Verdun.

was under the orders of Brig. General William Mitchell and disposed of 6ro machines which could be utilized on the St. Mihiel front.

${ }^{4}$ In his report to the Secretary of War, General Pershing graciously acknowledged the aid which we had brought on this occasion. 


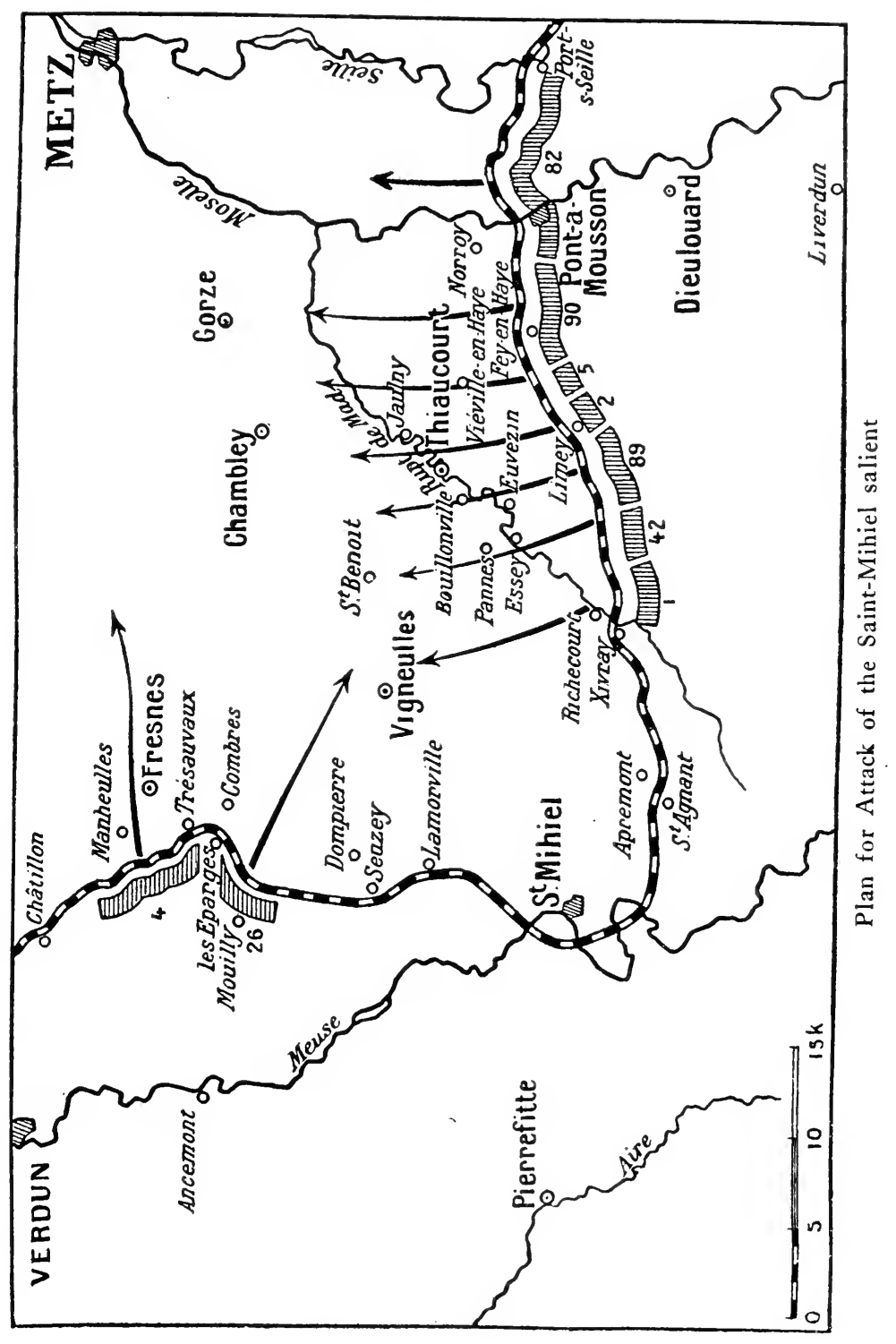



Naturally, this line was but thinly held. Every precaution was taken not to awaken the suspicion of the foe by any ostensible change upon the front. The relief of the troops who were not to participate in the attack was effected as late as possible. Numerous artillery formations were placed in battery positions during the nights immediately preceding the attack. But some important artillery reënforcements had to be placed on their position beforehand, so as not to block the roads, and when it was known that the difficulties attending their emplacement would be too great to be rapidly overcome.

At the time, the First American Army entered upon the scene of action, its staff was at Ligny-en-Barrois, having arrived as late as possible in order not to excite suspicion. As we have already remarked above, all plans and documents which such an action called for had been elaborated at Neufchâteau.

Remarkable work was accomplished by General Drumm, chief of staff of this First Army, and also by his collaborators who had been chosen scarcely a month before. No unforeseen or disagreeable accidents checked the troop movements either by rail or by road. During these concentration marches, 500,000 men and important material had reached the zone of operations.

As for the numerous "plans of employment" which were necessary to carry out this attack, enough may be said in praise of their value and precision when we state that those presented to General Pétain were neither criticized nor modified in the slightest degree by him.

The plan of attack conceived by General Pershing included three distinct operations:

Firstly: A main attack starting from the line Fey-enHaye-Xivray, which should advance in three successive 
bounds from south to north, clean up the plain of the Woevre as far as the line passing through the villages of Vigneulles, St. Benoit, and Jaulny. This operation was confided to the First and Fourth American Corps.

Secondly: A secondary attack starting from the Meuse Heights between Mouilly and Tresauvaux, directed toward the southeast was, at the end of this maneuver, to bring the assailants up to the front of TresauvauxVigneulles, where contact would be established with the left wing of the main attack. This secondary operation was to be launched by the Fifth American Corps.

Thirdly: A general demonstration was to be made all along the enemy front included in these attacks; that is to say, around the entire point of the salient from Xivray to Mouilly, passing through Apremont, St. Mihiel, La Morville, and Seuzey. This was to be entrusted to the Second Colonial Corps (French) which was to cover both the left flank of the main attack and the right flank of the subsidiary one.

The converging of the two attacks as they closed in from behind on the eastern slopes of the Hauts-de-Meuse, would naturally liberate the town of St. Mihiel, important both on moral and tactical grounds.

This plan had many advantages. Even in case only one of the American attacks was successful, the town of St. Mihiel and the heights of the Meuse would be freed. In case of a complete success, the entire defensive organization of the enemy from his front lines in the salient reaching back far into the Woevre plain would fall into American hands. In both alternatives, the ParisNancy railway would be disengaged and made ready for traffic.

In order to execute this plan, the First Army, under 
the direct orders of General Pershing, was distributed as follows :

On the southern face of the salient at the extreme right of the front of attack we find the First Corps under General Liggett's orders, the same chief, with the same staff, whom we have already seen operating on the Ourcq, the Marne, and the Vesle. Only his commanding officer of artillery was changed, General Lassiter having passed on to the Fourth Corps artillery, being better acquainted with the ground covered by that section of the attack. A French officer, General Vincent, had replaced General Lassiter at the artillery direction of the First Corps. Headquarters were at Saizerais, and the corps comprised the Eighty-second, Ninetieth, Fifth, and Second Divisions, lined up from Port-sur-Seille to Limey with the Seventy-eighth Division which was held in reserve near Dieulouard. The Eighty-second Division, although deployed, took no part in the initial assault. Astride of the Moselle near Pont-à-Mousson, this division simply covered the right flank of the general offensive. On the thirteenth of September, we will find its left wing moving forward in order to conform to the advance of the main forces.

The Fourth Corps was linked to the First, being placed on its left. General Dickman, whom we have seen directing the Third Division during recent engagements on the Marne and the Ourcq, was in command and had taken up his headquarters at Toul. ${ }^{5}$ His corps stretched from Limey to Richecourt and comprised the Eighty-ninth, Forty-second, and First Divisions in first line, and the Third Division in reserve, near Royaumeix.

${ }^{5}$ An advanced post of command had been organized in the village of Royaumeix. 


\section{The American Army in the European Conflict}

Further west came the Second Colonial French Corps, under General Blondlat (headquarters, Ernécourt), its Thirty-ninth Division holding all the line between Richecourt and St. Aignant; its Twenty-sixth Division stretching from the latter to the Selouze Wood on a ten-mile front, taking in the point of the salient as well as the town of St. Mihiel; its Second Cavalry Division was between the Selouze Wood and Mouilly Village. Of the three aforenamed units, the Second Cavalry Division alone was sufficiently concentrated and capable therefore, as we shall see, of taking an efficacious part in the general offensive.

Proceeding to the northward, we find the Fifth American Corps with General Cameron in command. His activities as chief of the Fourth Division during the eighteenth of July offensive has been already described.

General Alexandre, detached from our Twentieth Corps, had charge of the artillery.

The Fifth American Corps (headquarters, Ancemont) comprised the Twenty-sixth American, the Fifteenth French, and the Fourth American Divisions holding the Mouilly-Châtillon-sous-les-Côtes front. The latter was to take a limited part in the general attack, its mission consisting merely in covering the left flank of the troops marching toward Vigneulles, and operating small raids in the Woevre toward Fresnes and Manheulles.

The army held in reserve two divisions, the Thirty-fifth at Liverdun and the Ninety-first at Void. We should, however, remark that the Eightieth Division at Prouville and the Thirty-third near Verdun were not engaged at this moment in any action and, if necessary, could be called upon. We may therefore consider these two divisions as part of the army reserve. 
The artillery was split into three large groupings which corresponded approximately to the fronts occupied by the three American attacking corps.

The northern grouping which supported the Fifth Corps offensive was commanded by General Alexandre.

The two southern groupings were under the direct command of General McGlachlin who also controlled General Chamberlaine's railroad artillery. The fire of the southern groupings was intended more especially to support the advance of the First and Fourth Corps.

The resources of the staff were severely tested during this attack, with its complicated material and wide troop movements. In order to carry it through, General Drumm and his associates were obliged to study the condition of the roads and transport facilities in the two French Army groups contiguous to the American zone of operation and also to take into consideration the severe regulations governing, at that moment, the transports by rail. All these difficulties served more effectually to demonstrate the zeal and ability with which General Pershing's staff managed these vast preparations.

Let us now glance beyond the lines.

Facing the army enveloping the St. Mihiel salient and observing from east to west, the enemy order of battle seemed on the twelfth of September, as far as could be judged, the following: Two Hundred and Fifty-fifth Division, Seventy-seventh Reserve Division, Tenth Division, Fifth Landwehr Division and One Hundred and Ninety-second Division, then the Thirty-fifth AustroHungarian Division, and finally the thirteenth and eighteenth German Landwehr divisions.

Since the beginning of the month, numerous troop movements had been observed in the enemy's rear. 


\section{The American Army in the European Conflict}

The examination of prisoners led us to believe that the evacuation of the St. Mihiel salient was contemplated and had even perhaps begun.

Under these circumstances, rapid action was imperative. The order to attack was given by General Pershing after having consulted with General Pétain as to the hour. $\mathrm{He}$ also asked the opinion of his subordinates as to whether a preliminary bombardment would be advisable and whether it should be of long or short duration. $\mathrm{He}$ then retired to his office alone and shortly after gave orders that the attack would commence on the following morning, September twelfth, at five A. M. for the First and Fourth Corps who were stationed in the Woevre and who were to march northward toward Thiaucourt and St. Benoit, at eight o'clock for the Fifth Corps, whose action was to take in the Meuse heights.

All the assaults were to profit by a four-hour preparatory bombardment. General Pershing deemed this bombardment necessary both for the demoralization of the foe and the preliminary destruction of his solid and numerous redoubts. He also authorized a few shots during the afternoon of the eleventh in order to find the range which would enable the 75 -millimeter batteries to adjust on the morrow their rolling barrage.

When the twelfth of September dawned, the commander-in-chief sought an advantageous post of observation on a high plateau overlooking the Woevre, and there he was joined by the Secretary of War, Mr. Newton D. Baker.

The mist which mingled with the smoke prevented a view of the troops moving across this moist plain, but on all sides of the vast battle-ground and above the clouds overhanging the Woevre, there could be perceived long 
trails of sparks which flowered in stars of green and yellow, code rocket signals sent up by the first infantry assault waves and which cried out to the supporting artillery: "Lengthen your fire, our objectives have all been reached."

Although the enemy was expecting an attack in the near future, he was greatly surprised when the bombardment really began. He had supposed that his retirement, which the high command was preparing, would be effectuated before the American attack. In reality, the abandonment of the St. Mihiel salient had been for a long time in contemplation. Orders had even been given to bring many of the heavy ordnance to the rear and dispose the field guns in depth formation. The retreat, thus begun, was on certain points being effectively carried out when the American gunners opened fire on trenches, villages, strongholds, and roads both on front and rear on batteries and the wooded areas. The long-range guns attained the railway station of Metz. The enemy, completely immobilized, was obliged to interrupt his movement of retreat and face the attack to the best of his ability.

The assault was indeed superbly carried out. Although the tanks had a hard time in the inextricable system of trenches which four years of occupation had accumulated on this ground, the foot soldier went over the top in great style. The barbed wire, considerably rusted, was easily severed by the soldiers with the aid of wire-cutters. Often complicated entanglements were leaped or scrambled over without having been destroyed. The advance was accomplished with such remarkable rapidity that the charges prepared in view of destroying the enemy's defenses were not even exploded. 
The general progression was made without any untoward accident. Vigneulles, the goal where the two American attacks were to converge, was first entered by patrols of the Twenty-sixth Division (Fifth Corps) and then occupied in force by the First Division (Fourth Corps). This march of General Dickman's left wing, where the First Division was operating, may be taken as a model of a well-conducted attack. The divisional artillery, whose accurate fire accompanied the infantry advance, was pushed forward at an early hour, one battalion of artillery accompanying each regiment. The telephone wires linking the front and rear were progressively unrolled so that the commander of the First Division was kept in touch with his first-line battalions as they marched northward.

It would be unfair to dwell only upon the rôle taken by the First and Twenty-sixth American Divisions in these vast operations, and pass over in silence what was accomplished by other units. The Second Division seized Thiaucourt in a splendid rush; the Ninetieth Division drove the enemy out of the Norroy quarries which were reputed impregnable. The Fifth Division, thanks to a well-conceived maneuver, executed practically without losses, stormed Vieville-en-Haye. The Eighty-ninth Division, deploying from the Mort-Mare Wood, attacked Euvezin and Bouillonville; the Forty-second Division captured four villages among which were included Essey and Pannes. The Fifteenth French Division showed much tenacity in the attack on Eparges and Combres; as to our Second Division of dismounted cavalry, it progressed all the way to Dompierre-aux-Bois, taking more than 2,500 prisoners and only losing 130 men, of whom but 14 were mortally wounded. 
The American Army harvested that day an important booty - I6,00o prisoners, 443 guns of all calibers, and an immense quantity of war material. Very few losses were suffered, consisting of some 7,000 men, of whom the greater number were but slightly wounded.

To the tangible results above enumerated may be added the immense moral effect obtained by this brilliant action. The strength of the American Army thus proved, heartened and encouraged men, officers, and staff of all the Expeditionary Forces.

In the same measure, these qualities were recognized by the common enemy, who was correspondingly discouraged.

The German high command was indeed much struck by the manner in which the ensemble of the action had been carried out. Here is the account given by the general headquarters of the beaten German Army, regarding the conduct of the victors of September I 2 th:

"Three French divisions and at least nine American divisions took part in the attack under General Pershing's orders. How many divisions remained in reserve we have not ascertained. Among those counted, three (First, Second, and Forty-second) were first-class attacking troops; two (Fourth and Twenty-sixth) were good fighting troops which had already done good work in other important affairs; three (Fifth, Eighty-ninth, and Ninetieth) had been in line on other sections of the front before, having been opposed to our detachment, and one in reserve, the Thirty-fourth, had not yet been brought into line.

"The attack was preceded by an artillery preparation lasting four hours to which was added a short bombardment with trench mortars.

"The batteries fired with great precision, not only on our first lines but also on our rear communications.

"The principal attack was directed against the face of the salient between Richecourt and Fey-en-Haye, on a ten-mile front. 


\section{The American Army in the European Conflict}

"Eight American divisions with one French took part in the assault.

"The enemy advanced to a point north of Thiaucourt, thus rendering our tenure of the St. Mihiel salient impossible. As a result of this situation we received orders to leave the positions and to retire on our Michael line (Hindenburg) which was done according to instructions.

"The Americans proved clever with their machine guns and are tenacious in defense and depend much on these instruments which they possess in great number.

"The artillery preparation preceding the assault was ably conducted, and the artillery was well directed - the gunners succeeding' in changing objective in minimum time and with great precision. The linking between artillery and infantry was done without fault. If the infantry encountered a nest of machine guns, they rapidly retreated to the rear and a renewed fire was immediately started against our machine-gun emplacements. Many tanks took part or were ready to take part in the action; it was unnecessary, as the masses of infantry had already made victory certain."

On September $13^{\text {th }}$, in the morning, General Pershing and General Pétain entered St. Mihiel side by side. They had scarcely crossed the Meuse on a rough wooden bridge hastily thrown over the river near the spot where stood the old stone arches blown up in I9I4, than the civil portion of the population, which had remained in this locality since the beginning of the war, received them with enthusiastic greetings. The streets were hung with flags, even the ruins were bright with bunting in honor of these two liberators. What seemed even more extraordinary to the inhabitants, cut off as they had been from all news of political events, was the appearance among the Americans of their Secretary of War, anxious to follow the operations and to investigate the extent of the damage 
caused to our towns and country by the enemy's occupation. ${ }^{6}$

In the last house at the end of the town, pillaged like the rest and in lamentable plight, he noticed on a bare wall one engraving still suspended. This engraving represented General Lafayette.

In the United States, the victory of St. Mihiel will be long remembered and history will recount that here, on this foreign soil, four thousand miles from home, was seen for the first time so powerful an American army. The battle of St. Mihiel will gradually efface the memory of Gettysburg where Lee, less adroit than Pershing, tried to strike at the apex of a triangle, instead of sapping it at the base, and as time goes on these forces, 500,000 strong, drawn from South and North united in a common effort will cause the discords of the past to be forgotten.

During the first days of September, General Pershing had also to prepare, on another part of the front, a vaster operation and set on foot an attack whose execution entailed more serious difficulties.

In view of these extensive operations, it became necessary to change the center of gravity of the American forces immediately after the Woevre attacks, and make it possible to take the offensive between the river Meuse and the Argonne forest.

The Fourth French Army was to give battle on almost the whole of its front at about the end of September from the Aisne opposite Servon as far as the Suippe.

"The "Grande Rue," in olden days the name of the principal street of the town, now bears the title "Rue du General Pershing." 
Westward, the Fifth French Army, profiting by this operation, was to gain ground in a turning movement west and north of Rheims.

Marshal Foch desired the Americans to take the offensive toward the east, thus prolonging the line of attack and to advance in the direction of Buzancy and Sedan. These orders, as interpreted and transmitted by General Pétain to the Fifth and Fourth French Armies and the First American Army, caused a new line-up of General Pershing's forces.

In order to break through the front at the point where the Americans were about to strike, as well as to be able to rapidly exploit the ground gained toward Buzancy and later toward Sedan, it was necessary to place important effectives in line, the more numerous where the quality of the troops was not presumably of the best.

It was necessary to select the divisions which were to be left on the newly conquered Woevre front, designate those asked for by the French command in order to reenforce General Gouraud's attack, and eliminate those. who, whether on account of insufficient training or lack of transportation, were judged incapable of fighting. It was considered possible to bring into the theater of operations fifteen divisions of which three at least might join the rest some days after the initial attack, if this battle were to take place, as was contemplated, on the twenty-second of September, I 9 I 8.

A close study of the front, of the nature of the offensive about to be undertaken, the extent of the ultimate objectives, decided General Pershing to engage, from the first, nine divisions. These were naturally chosen from among those whose entry into line might take place without too great difficulties in transportation and concentra- 
tion and without hindrance to the operations already under way.

The nine divisions which were to take an initial part in the future offensive were accordingly selected rather by necessity and circumstances than by a free choice in the matter.

We desire here to underline the immense effort furnished by General Pershing and his staff to set this attack on foot. A glance at the effectives about to come into line is therefore essential.

Out of these nine divisions, three alone possessed their own artillery services and had participated in active operations. Two had been occupying quiet sectors during less than two months, another had experienced but ten days of trench life, still another only sixteen days, and two divisions had never been under fire.

Considering that at the last moment contingents coming from the severely tried region of the Aisne and Marne had to be completed with green troops we may suppose that among the future combatants there were more than I00,000 men who had not yet been at the front.

Four of these nine divisions were only made acquainted with their artillery on the battle-field. We may add that the lack of proper transport facilities and horses rendered the troops inelastic, for the units possessed but 70 per cent. of the animals and wagons which should normally complete their war equipment.

The divisions ultimately placed in reserve with army and corps possessed more experienced troops, but even they lacked their own services, their batteries having been taken to reënforce the divisions ranged in the first line.

General Pershing was obliged to test the capacity of his contingents to the utmost. It was also difficult to find 
the requisite number of officers for these units. Once again, circumstances necessarily influenced his decisions.

The Third Corps was brought from the Aisne front, and, from the St. Mihiel salient, General Pershing transferred the First and Fifth Corps. He thus procured a staff direction which, though lacking in knowledge of the ground on which they were to work, possessed experience of active operations.

Such was, at this time, the situation of the American effectives. The numerical aid brought us by our new ally was greater than could have been expected.

General Pétain, without waiting for the St. Mihiel affairs to be concluded, had placed at the disposition of the American commander-in-chief the staff services of the Second French Army whose front stretched from the Meuse heights to the Argonne and took in Verdun. ${ }^{7}$

This staff was to attend to the execution of the plan for transport and concentration, ordering into the immediate vicinity of the front lines the infantry and artillery which were to take part in the battle.

The American divisions which were to participate in the initial assault, with the exception of those already in line, were first to be posted in the rear of their ultimate position, masked by a thin curtain of men in horizon blue uniforms. These were to remain in place up to the night preceding the attack, when they were to disappear, leaving to the soldiers in khaki the possession of the parallels from which their surprise was to be launched.

By the twenty-second of September, the French Second

7 The placing of the forces above enumerated on the Meuse-Argonne front necessitated the withdrawal of eleven divisions, French or Italian, and the entry into line of fifteen American divisions sustained by a powerful artillery. All these movements had to be executed between the fourth and twenty-fourth of September. 
Army, whose name is immortally associated with that of Verdun, had quitted the front of its past exploits, and General Pershing's lines extended as far as la Harazée in the Argonne Woods. The American First Army, containing, nevertheless, several French units, was now established on a seventy-mile front.

When all the shifts necessary for the future attack and the installation of troops on the conquered Woevre position had been made, the American Army was disposed as follows:

General Dickman's Fourth Corps, with its right across the Moselle at Port-sur-Seille, its left at Le Chauffour-enWoevre, had in line the Ninetieth, Seventy-eighth, and Forty-second Divisions. In reserve, it held the Fifth. Thus its effectives were formed exclusively of American units. $^{8}$ The Seventh Division was on the march to rejoin the corps whose headquarters were installed at Menilla-Tour.

From Le Chauffour to Menil in the Woevre, the Second Colonial Corps, minus one French division (the Twenty-sixth) but plus the Twenty-sixth American Division, was commanded by General Blondlat with his headquarters at St. Mihiel.

Continuing northward, the Seventeenth French Corps, with headquarters at Fort Regret, held the Verdun salient from Mesnil to the Meuse.

The First American Division, placed behind and slightly westward of the Seventeenth French Corps, may be considered in this instance as filling the rôle of corps reserve while awaiting the arrival of the Twenty-sixth French Division coming from the Second Colonial Corps.

8 The sixty-ninth French division prolonged the Fourth Corps along the right wing and was later included in the American First Army. 
Finally, from Meuse to La Harazée, all along the future front of attack, we find the forces disposed as follows :

To the right, on the Meuse-Malancourt front, the Third Corps with General Bullard's headquarters at Rampont, having in line the Thirty-third, Eightieth, and Fourth Divisions, in reserve the Third Division.

In the center, on the Malancourt-Vauquois front, the Fifth Corps with General Cameron at Ville-sur-Coussances, held in line the Seventy-ninth, Thirty-seventh, and Ninety-first Divisions, in reserve the Thirty-second Division.

To the left, on the Vauquois-La Harazée front, the First Corps, with General Liggett's headquarters at Rarecourt, held the line with the Thirty-fifth, Twentyeighth, and Seventy-seventh Divisions, in reserve the Ninety-second. ${ }^{9}$

During the actions between the Meuse River and the Argonne Forest begun on the twenty-sixth of September and continued until the armistice, these three corps occupied the same relative positions. The Third Corps always advanced with its right flank along the river; the First Corps operated with its left engaged in the wooded Argonne region in liaison, more or less close, with the Fourth French Army; the Fifth Corps always occupied the center of the line of battle.

The general reserve of the army was composed of three divisions: the First in the neighborhood of Blercourt, the Twenty-ninth near Osches, and the Eighty-second in the Clermont-en-Argonne region.

9 The artillery of the First American Corps had been concentrated under the orders of General Walch, detached from the Seventeenth French Corps. 
On September $25^{\text {th, }}$ the Fifth Cavalry Division (French) had been placed at the disposal of the First Army commander, receiving orders to proceed during the night of the twenty-fifth to the Passavant neighborhood close to the future field of action, and from whence it could be ready to intervene, if necessary, in the coming battle.

The Franco-American artillery, whose fire was to second the attack, comprised army batteries and the rest of the artillery divided between the corps and the divisions.

The army artillery under General McGlachlin was grouped in five commands, the names alone indicating their normal sphere of activity:

The Verdun command,

The Meuse command,

The Aire command,

The Aisne command,

The command of railway artillery.

The groups of Verdun, Meuse, Aire, and Aisne, in all, disposed of 340 pieces of all calibers from the $145 \mathrm{~mm}$. to the $270 \mathrm{~mm}$. The railway artillery under General Chamberlaine counted 40 pieces, varying from 305 to $400 \mathrm{~mm}$.

The divisional and corps artillery attained in round numbers 2,400 guns of which $\mathrm{I}$, OOO were 75 's. These numbers do not include the trench mortars of small caliber. The Franco-American artillery, if lined up, could have placed a cannon at every ten yards.

As the woods of Cheppy and Malancourt were at the center of the American attack and the Argonne Forest at 


\section{The American Army in the European Conflict}

its left, this permitted an economy of fire in these regions to the advantage of progress in the open ground.

Thus it can be said that the Americans were well furnished in artillery. The corps posted in the Woevre and on the Meuse heights, which covered the right flank of this attack - that is to say, the Fourth American Corps, the Second Colonial, and the Seventeenth French - had not been deprived of their guns to any notable extent, so that they were able to help the main offensive by prolonging the fire on their own fronts and also by making, on the day set for the assault, numerous raids in enemy territory. ${ }^{10}$

Such were the dispositions taken when the night of the twenty-fifth fell. It was impossible to prepare the attack for an earlier date. Besides this date accorded with that on which the Fourth French Army would be ready to take the offensive. Consequently General Pétain gave the order to attack on the morning of the twenty-sixth from Meuse to Suippe, on a front of some forty-five miles. According to his idea the French Army advancing northward would approach the American forces with its right; on the other hand, the flow of the Meuse River would oblige the Americans in their march toward Buzancy to incline to their left. Thus the two masses would find themselves in touch at the Grand Pré Pass, while pursuing their mutual advance toward Mézières and Sedan. The common object of the two armies was to throw the enemy across the Meuse and force him to beat

${ }_{10}$ The French artillery placed at the disposal of the American forces for these operations consisted of:

\begin{tabular}{|c|c|c|c|}
\hline & $75 \mathrm{~mm}$. cannons & Heavy cannons & Trench mortars \\
\hline September $26 \ldots \ldots$ & 456 & 1,002 & 254 \\
\hline October $\mathbf{r}_{4} \ldots \ldots \ldots$ & 132 & 607 & 48 \\
\hline November $\mathrm{r} \ldots$ & 300 & 319 & 48 \\
\hline
\end{tabular}




\section{Operations Between Meuse and Argonne 285}

a retreat through the Ardennes where the lack of roads and communications would oblige the Germans to a more accentuated and perilous withdrawal.

The French high command founded its hopes especially upon the American troops in this combat, for it was to be supposed that the Fourth Army would meet with enormous difficulties in crossing the Aisne if General Pershing's troops had not succeeded, as they passed up the right bank of the river, in freeing the passage at certain points. It might also be foreseen that the enemy would make a particularly fierce resistance between the Meuse and Argonne, as this was the vital point of their line.

The front of the Fourth Army's attack did not extend to the Aisne Valley, and as the American front was limited to the Argonne, the commander-in-chief of the French forces constituted, between the river and the forest, a liaison detachment which included two infantry regiments, of which one (the 368 th, colored troops) came from the Ninety-second Division. The artillery was French.

This detachment was to link the two attacks and neutralize the western fringes of the Argonne.

Let us now return to the First American Army. On the twenty-second of September, headquarters (advanced echélons) were installed at Souilly. There the special train of the army commander was side-tracked and in the offices which had successively served Generals Pétain, Nivelle, Guillaumat, and Hirschauer, great activity reigned. In spite of all the diligent endeavor which we ourselves can testify to, it was materially impossible, as we have already explained, to prepare an attack before September 25 th. 
Work went on night and day in the staff offices; the same lamps which lighted General Barescut's map during the heroic months of the Verdun defense now for many nights served to illuminate that of General Drumm.

General Pétain had not set any hour for the attack, nor fixed the duration of the preparatory bombardment, judging that on so extensive a front the simultaneity of assault was not a necessary condition of success. He left each army commander free to determine the hour on which each would set their troops in motion, and left to each, also, the mode of preparing his artillery attack.

General Gouraud ordered a six-hour bombardment; General Pershing prescribed a three-hour preparation, and he also authorized his field artillery - as he had done at St. Mihiel - to verify the range of their barrage on the day of the twenty-fifth. In case of necessity, he even permitted his counter batteries to act six hours before the general attack.

The Seventeenth Corps and the Second Colonial, together with the Fourth American, were all to execute some deep raids from the Meuse Heights north of Verdun to Pont-à-Mousson on the Moselle - these were to be preceded by a six-hour bombardment in conformity with the plans of the Fourth French Army.

The enemy order of battle was at this time known. He had eleven divisions in an extended line fronting the Americans posted on the Woevre and Meuse Heights who were not to participate in the attack. Five divisions only held the front between Meuse and Argonne against which the main assault was to be directed.

Eleven divisions (of which four were in process of reconstitution) were reported in the Metz region, so that it was easy to conclude that the enemy, much shaken by 
the fight at St. Mihiel, feared an American attack in the Woevre even more than an offensive in Champagne. $\mathrm{He}$ had, however, along a front which extended from the Meuse to Rheims, disposed his forces in depth, officers and soldiers had been warned by their high command against a Franco-American offensive announced for the twenty-ninth of September.

As much to facilitate the study of this battle which, beginning on September 26 th, finished only with the armistice, as to obtain a clear account of proceedings from reports of those officers who participated in the divers phases of this great operation, the American high command decided to divide the action into three distinct periods. We shall naturally adopt, with slight modifications as to the length of each phase, this perfectly logical division.

In the first phase, we shall include the initial attack and the advance which brought the American infantry, engaged well ahead of its artillery, in contact with the enemy reserves. This brief and brilliant period may be designated as the "Success of late September."

The second phase is that of a perpetual combat during which the Americans, although they gained ground only foot by foot, continued steadily to advance, wearing out the enemy and enlarging the front of attack. This period covered the whole following month and we may call it the "Incessant fighting of October."

The third and last phase is naturally that of the "pursuit." Beginning on November Ist by a general assault, the first American Army, reconstituted in view of a definite operation, conducted a regular advance in constant touch with the enemy, which forced him back until the eleventh of November, at which date, and for reasons 


\section{The American Army in the European Conflict}

entirely independent of the will of the soldier, a speedy termination of hostilities was reached.

Let us take up our narrative where we broke off when, after a bombardment of three hours, perhaps the most violent of the war, and which carried unprecedented consternation into the enemy ranks, the American infantry attacked on the morning of September 26th at 5.30.

Advancing, as we have previously seen them do, close upon the rolling barrage, the troops rapidly traversed the furrows formed by the abandoned trenches, ground honeycombed with shell-holes, overturned by a rain of shot during four years when it had been constantly battered by both sides and to which the British have given the name of " No Man's Land." With almost equal celerity they crossed the first enemy lines and the auxiliary defenses which, although bristling with barbed wire, were but thinly manned.

On the entire front, the second lines were reached and held, in spite of fierce enemy resistance, becoming more and more accentuated as the waves pressed on. The Americans pushed forward, attaining a four-mile advance at points where the defense had been particularly strong, and as much as six miles, where the German machine guns had made less havoc in the advancing ranks.

During the first day the troops had taken the villages of Drillancourt, Septsarges, Cuisy, Malancourt, Very, Cheppy, and Varennes.

Unfortunately, toward the center, the advance of the Fifth Corps was checked before it had attained Montfaucon. Great difficulty was experienced in debouching from the Malancourt and Cheppy Woods. The infantry which had traversed these thickets was no longer in force 


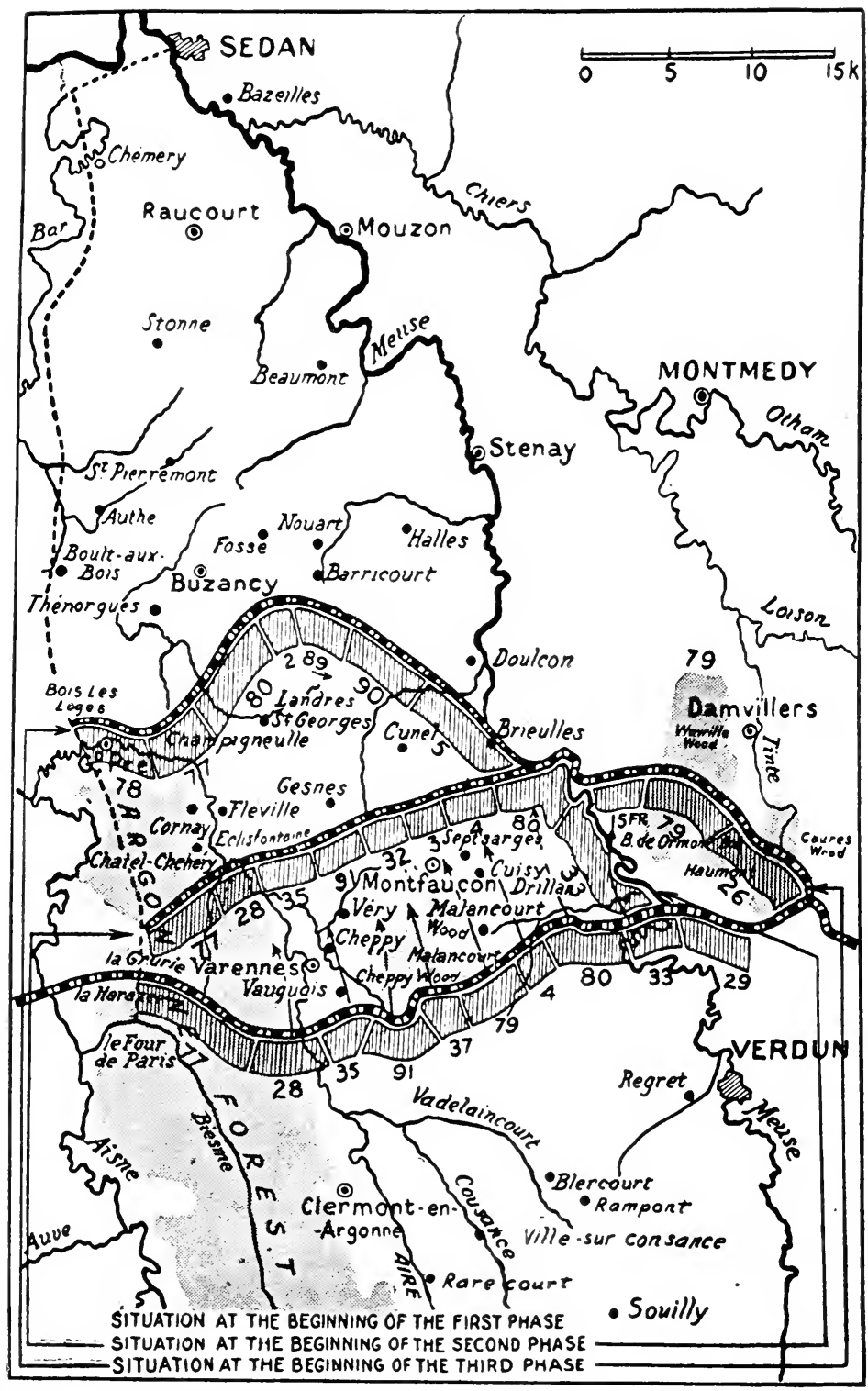

Operations between Meuse and Argonne 

sufficient to scale the redoubtable heights upon which this village is perched. The tanks in many spots had difficulty in getting into the enemy lines, in others they rendered excellent service, preceding the infantry and doing good work not only on the twenty-sixth but also during the following days. ${ }^{11}$

On the twenty-seventh and twenty-eighth, the attacks continued along the entire front of the First Army, where considerable progress was made. Montfaucon, Epinonville, Charpentry, and Apremont were taken. The three army corps either attained or passed beyond the objectives which they had been assigned.

Such violent infantry combats were engaged for the possession of these latter strongholds that General Pershing thought best to organize defensively the line Gercourt - Drillancourt - Bois-Juré - Dannevoux Namtillois - Eclisfontaine-Charpentry - Montblainville - Apremont.

The first bound, which inaugurated the lengthy combat between Argonne and Meuse, had been effected with rapidity and precision. Success crowned the American efforts; the enemy had lost during the last days of September all his first and second positions, he had been constrained to retreat without shelter into the open country, and he had lost 9,00o prisoners and left more than roo cannons in our hands.

If we may judge by the number of troops which he had thrown into the fight in order to back up his units which had sustained the shock of the twenty-sixth of September, we may suppose that his anxiety had been extreme. The following divisions successively passed before the Ameri-

11 The number of tanks of which the American Army disposed on September 26 th was 381 , of which 239 were French. 
can front: Second Landwehr, Thirty-seventh Reserve, Fifth Bavarian Reserve, Seventy-sixth Reserve, Fifty-second Division, so that on the thirtieth of September, at the conclusion of this first phase, the forces of the defender were about equal to those of the assailant.

General Pershing, on his side, was obliged to relieve the Thirty-seventh Division by the Thirty-second and the Seventy-ninth by the Third.

The cavalry could not be utilized, as no opportunity was given for operating in open country. The aviation, on the contrary, had been extremely active in spite of bad weather conditions. Often flying extremely low, the aviators were able to report on the infantry advance and the defensive arrangements of the enemy. ${ }^{12}$

The liaison detachment had encountered many obstacles to its progress between the Aisne and Argonne; the Fourth Army had realized the advance expected of it by the high command.

During this first phase, the young American Army, even that portion which had not before seen fire, had justified, by its fine qualities of energy and dash, the most sanguine hopes of all who had felt confidence in its future.

Would it now add qualities of endurance and tenacity to those already exhibited? Would it be easily adaptable to the exigencies of an incessant battle in open country and in the woods? The study of the second phase of this combat may give us the answer to these questions.

The first bound which the Americans had made during the initial days placed the infantry on an advanced line

12 The aviation service of the First American Army comprised, at this date, 660 machines manned by American pilots and 180 machines manned by French pilots. 
fronting a multitude of German machine guns, installed in depth formation, and which were hard to destroy without the support of cannon.

In every hollow or thicket on the fringe of every wood, the foot soldier came up against these deadly weapons, backed by countless others. Progress was slowed up, and just at the moment when the infantry had most need of artillery support, the guns were checked by the difficulties of changing their emplacements.

The rain-soaked ground was deep in mud and extremely slippery, so that to draw the guns across country was practically impossible.

Moreover the zone which included the old defense systems of trench warfare was like the No Man's Land above described, filled with ridges and shell-holes.

All transportation and artillery movements were thus obliged to keep to the roads which were far from numerous, and it was scarcely possible for each army corps to have at its exclusive disposition even one narrow way permitting a continuous line of travel.

At the spots where the roads crossed the abandoned trenches, it was necessary to make bridges, inclines, etc., in order to permit passage. The American engineers and our territorial battalions vied with each other, night and day during many weeks, to better the condition of the ways which linked the network of roads between front and rear. Blocks in the traffic rendered the supplying of the troops precarious and checked the movements of the allied artillery.

The American military police, charged with the maintenance of order, circulation, and transport, came against all sorts of obstacles, augmented by the essential ones of 


\section{The American Army in the European Conflict}

language, climate, ignorance of the ground. We who have seen the Americans overcome so many of the diffculties placed in their way, should do justice to the efforts made by them under these circumstances.

Every one worked with zeal and ardor. The artillery, so as not to block the roads, often put a crew of men at the wheels of the stalled cannon and succeeded thus in helping the heavy pieces through No Man's Land, thereby accomplishing the first forward bound of their batteries.

The commander-in-chief himself again set the example of activity, hurrying forward the repairs, hastening from one command post to the next in order to push on the fighting.

The enemy, on the contrary, as he retreated farther and farther back, found himself in easier ground, where traffic on the roads was only interrupted by the harassing fire of the American batteries.

By the time the second phase of combat had begun in the zone of the First Army, circulation was once more normally established and permitted the steady advance of artillery and prompt arrival of munitions.

We have already called attention to the fact that only a small number of American divisions which took part in this affair disposed of their own artillery. It was not until the very day of attack that some of the infantry was linked, for the first time, with its supporting guns. The difficulties of a divisional artillery called upon to reestablish communications with a green infantry from the advanced positions attained after their first forward bound may be easily imagined.

In spite of all these obstacles, at which we have only hinted because a complete enumeration would be impracticable, there was no let-up in the fighting. It became a 
question merely as to which opponent would be able to wear out his adversary. During all October, the Americans hammered away at the German positions, gaining ground foot by foot, now bombarding, now attacking the machine-gun nests, now organizing a general attack which would at least immobilize the foe if not pierce his line.

The commander-in-chief had ordered a general attack

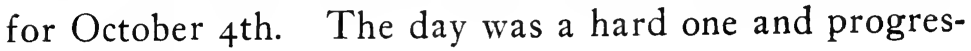
sion limited.

On the right, the Third Corps advanced at an oblique angle toward the west up to the Brieulles-Cunel road, where it was checked.

At the center, the Fifth Corps seized the village of Gesnes, but could not proceed beyond.

Toward the left, in the winding Aire Valley and on the wooded slopes of the Argonne, the First Corps realized a two-mile advance.

On the seventh of October, this same corps took Chatel-Chehery and went forward as far as Cornay, where on the following day the Americans penetrated. After this new advance, it became evident that the enemy was strengthening his defense so as to render it impossible to pierce his lines on the section of the front where the First Army was now engaged, and it was easy to foresee that the process of wearing him out would be a long one.

General Pershing thoroughly understood the situation. $\mathrm{He}$ had discussed the phases of the combat with General Pétain and had decided to widen his attacking front by an action which should be confided to the Seventeenth French Corps operating on the right bank of the Meuse.

Accordingly, General Claudel received orders to attack between Beaumont and Samogneux, and to push forward 


\section{The American Army in the European Conflict}

on the crest separating the Meuse basin from the Loison Valley.

The Seventeenth Corps, already reënforced with the Twenty-sixth French Division, had at its disposal the Twenty-ninth American Division and most of the elements of the Thirty-third Division engaged west of the river on the wing of the Third Corps, and which could coöperate usefully in this action.

In order to give General Claudel a greater facility to carry out his operation, the front of attack was limited on the right by Beaumont and the Thirty-third French Corps was interpolated between this village and Menil where the Second Colonial Corps had established its left. General Leconte, chief of the Thirty-third Corps, thus took direct command of the Tenth and Fifteenth French Divisions and established his headquarters at Belrupt.

The Seventeenth Corps was ready to attack on October 8th, thus participating in the larger operations which General Pershing had planned.

On the eighth and ninth, the German positions were once more subjected to a violent bombardment from the Argonne to and beyond the right bank of the Meuse.

On the Seventeenth Corps front, progress was made as far as the Haumont Wood; 3,00o prisoners were captured, but the attack which had gone smoothly at the start encountered the same obstacles as had already been met with on the left bank.

The enemy, strongly entrenched in the Cosenvoye and Haumont Woods, made a deadly use of his machine-gun concentrations, so that the fight was particularly arduous and sanguinary.

The Third Corps penetrated as far as Brieulles, while the Fifth Corps captured Fleville. 
On the tenth, the advance was continued, following an enveloping movement which was executed in conjunction with the Fourth Army, and thanks to which the entire Argonne Forest fell into our hands.

General Gouraud's right wing had reached the confluence of the Aisne and the Aire.

The historian desirous of finding the most dramatic episodes of the war would have to seek them in Argonne. From September 26th to October Ioth, the Americans fought in these wooded regions with a courage and a tenacity worthy of their French predecessors who in the terrible months of 1915 had held in the Grurie, at Bagatelle, Marie-Therese, and the Four-de-Paris.

We will give but an example: Following the attacks of early October, six companies belonging to the 308th Regiment and commanded by Major Whittlesey were cut off from the Seventy-seventh Division and surrounded by an enemy force superior in number. Officers and men refused to surrender. After four days of resistance and privations during which their own airplanes succeeded in dropping a few loaves of bread, but during which a rain of bullets and shells came from every direction and caused heavy losses, this handful of brave troops succeeded in maintaining their position until their comrades forced a passage to their relief.

The operations were now amplified on almost every front. The addition of the Thirty-third French Corps brought the number of army corps under the direct orders of General Pershing up to seven. A large number of American divisions had been engaged in other theaters, and the chief of the American forces now decided to form a second army.

His staff resources recently augmented with the 
graduates from the school of Langres, were now sufficient to form the headquarter services of the extensive units about to be constituted.

The First Army, which had so brilliantly fought under his orders, capturing more than 30,000 prisoners, now passed to General Liggett, who took command on October I 2 th.

On the same day, General Bullard was placed in command of the Second American Army, and at the head of this new formation he established headquarters at Toul.

The First Army continued to include the Thirty-third and Seventeenth French Corps, the Third, Fifth, and First American Corps. It proceeded to carry out its offensive mission remaining, however, stationary on its right wing. ${ }^{13}$

The Second Army maintained a comparatively passive attitude between Port-sur-Seille and Menil-en-Woevre, where from right to left we find in line the Fourth American Corps and the Second French Colonial Corps. The Sixth American Corps, in process of formation at Saizerais, was attached to this army.

We have seen with what method and logical sequence the commander-in-chief of the American forces grouped his units and disposed his staffs, in order to better his organization and prepare an American sector constantly spreading and acquiring daily a more national character.

General Pershing had shown no hesitation in assuming the responsibility of a direct command at a time when there was every reason to be anxious in regard to the

13 General Maistre, commanding the French Central Army group, was charged with coördinating the action of the First American Army and that of the Fourth French Army. 
success of his enterprise. Any doubt as to the final outcome was at present laid to rest. He knew that he might rely upon his two army commanders and content himself with a general supervision of the fighting forces. His headquarters, those of an army group, were established at Ligny-en-Barrois, and from this moment all the American operations were carried on under his immediate surveillance, and under the supreme authority of Marshal Foch.

Consequent upon the promotions of Generals Liggett and Bullard, General Dickman now took command of the First American Corps, General Summerall that of the Fifth Corps, and General Hines that of the Third Corps.

The First Army continued to exercise pressure on the enemy front, thus provoking the fall, one by one, of the strongholds maintained by the enemy machine guns.

On October I 4th, a general attack was launched, meeting, however, with a veritable dike of machine-gun fire. In spite of this the First Corps succeeded in taking St. Juvin and penetrated with certain elements into Grandpré.

The Kriemhilde position, last line of the enemy's defense, was attained.

On the eighteenth, fighting was particularly violent to the east of the Meuse and in the Caures and Ormont Woods, where our Seventeenth French Corps fought with admirable tenacity.

On the twenty-third, the Third and Fifth Corps reached the line of Banthéville; divers local actions and reconnoitering raids procured the army valuable information, all of which tended to show that the enemy, while still continuing a desperate resistance, was meditating an eventual retreat. 


\section{The American Army in the European Conflict}

Accordingly, General Liggett decided to regroup his forces in order to produce a more vigorous and coördinate effort. Persuaded that a strong pressure exerted along the entire front would obtain a striking result, he hastened to place his troops in posture to deal the enemy a hard blow and to follow up his advantage.

Believing the moment of a German withdrawal nearer than it actually proved to be, he even gave directions and marching orders to his five corps in case of this eventuality.

The Thirty-third Corps was to engage upon the Etain Road, the Seventeenth on Damvillers, the Third, Fifth, and First toward Stenay, Beaumont, and Stonne. The indispensable relief of certain units proceeded in order that the commander might have at hand an instrument capable of dealing the final blow.

The Eighty-second and Forty-second Divisions, which had both been subjected to heavy losses, were withdrawn. The artillery was completely reformed, the number of field guns considerably augmented, many heavy guns suppressed. Everything was prepared for pursuit after the enemy line had been broken, on the last day of October, when we may date the termination of the second phase of the combat between the Meuse and the Argonne.

It is difficult to follow the progress of a battle which took place on such a vast area, over broken ground and which covered thirty consecutive days. An idea may be had of the extreme severity of the conflict if we examine the effectives lined up by both adversaries.

At the beginning of the second phase, the Americans had in line between the Meuse and Argonne eight divisions (from October $23 \mathrm{~d}$ to November, their front was held by seven divisions only). To these American con- 
tingents, eleven German divisions were opposed. By a clever utilization of their effectives the Americans sent twelve of these new or reconstituted units into line while the enemy on his side deployed twenty-one divisions.

In allowing for the difference between the effectives of an American unit and a similar German one, it may be said that the Americans during the long process of "wearing out" the adversary possessed an approximately equal number, and constantly maintained the upper hand. The incessant fighting of October had enabled them to bring in 7,000 prisoners and 50 cannons which increased the booty taken by the first army since the St. Mihiel offensive to 32,000 prisoners and 600 guns. The number of prisoners alone thus greatly exceeded the number of Americans killed.

Neither during this second phase of the conflict, nor during the first, did the cavalry division, stationed near Binarville with a view to pushing forward should a breach be made, have the opportunity of taking part in these encounters. The cavalry quitted the American sector on October 24th.

During the last days of the month, the Thirty-third French Corps was also withdrawn from the American command, but its divisions remained in line, merely passing under the orders of the Seventeenth French Corps.

The First Army was ready for the decisive stroke and from the first of November we may date the beginning of the third phase of the Meuse-Argonne battle.

The French Fourth Army, stationed on the left wing, waited only the order for attack. The Third Corps held in line the Fifth and Ninetieth Divisions. The Fifth Corps, the Eighty-ninth and Second Divisions; the First 


\section{The American Army in the European Conflict}

Corps, the Eightieth, Seventy-seventh, and Seventy-eighth Divisions. This battle order remained unchanged during the first five days of pursuit.

Men and officers were keen for the fight, the morale was extremely high; news had come of the liberation of the Belgian coast, of the crossing of the Hindenburg Line by the British who had taken Lille, and of the French occupation of Laon. Many methods of prosecuting a war of movement had been successfully experimented during the periods of rest. The men had practiced marching and maneuvering by night. The small units had learned how to advance in columns along the roads to penetrate into the villages without firing a shot and to surprise the defenders. With his recent training in the use of cold steel, the American infantryman was eager for a chance of employing his bayonet.

The attack began at 5.30 A. M., after a two-hour preparation by the artillery. The plan was to seize the heights of Cunel and those to the north of Andevanne by a clever turning movement, during which maneuver the right wing was to deliver the principal effort. The plan took in Bayonville and Chemery, the village called Sivryles-Buzancy and a portion of the Loges Forest.

Even more distant objectives were indicated in the orders; Buzancy, Barricourt, and Boult-au-Bois where the lines would come in touch with the French Fourth Army.

The maneuver was carried out just as projected. The Third Corps on the right seized Aincreville, Doulcon, and Andevanne; the Fifth, in the center, conquered LandresSaint-Georges, Bayonville and Chemery; the First, which, at the left, had met with an obstinate resistance south of Champigneulles near the "Bois des Loges" advanced little. But, excepting on the front of this corps, the 
enemy made only a feeble reaction and his artillery had remained practically silent.

The first day's success encouraged General Liggett to vigorously pursue the offensive. Orders were given to take a strong grip on the foe and hurl him into the Meuse.

The Third Corps was to push toward Stenay, the Fifth Corps toward Beaumont, the First Corps toward Raucourt. On the other side of the river, the Seventeenth French Corps was to multiply attacks with the object of forcing the Germans to loosen their grip on the Meuse Heights to which they were still obstinately clinging.

On the second of November, the First Corps found its front freed by the advance of the American right and seized Thénorgues as well as Buzancy.

The next day, the Third Corps reached Halles, the Fifth Fossé and Nouart, the First Authe and St. Pierremont.

The long-range guns, keeping up with the advance, took under their fire the railway junctions of Montmédy, Longuyon, and Conflans. The American advance seemed to be breaking up the last resistance. The Germans were obliged to pass the bulk of their forces to the right bank of the Meuse, abandoning an accumulation of material so as not to embarrass their rapid retreat. The trees bordering the road were cut down to obstruct the passage of the pursuing troops.

On November 4 th, the Third Corps reached the Meuse between Villefranche and Stenay and, crossing the river, established two solid bridgeheads level with Brieulles and Clery. ${ }^{14}$

14 The Fifth American Division was the first to cross the Meuse, foot bridges being established at Brieulles and Clery, notwithstanding a forcible enemy resistance. 


\section{The American Army in the European Conflict}

Then came the turn of the Fifth and First Corps to reach the river in the vicinity of Mouzon and Bazeilles, near Sedan. In this retreat, the enemy abandoned $25^{\circ}$ cannons and 2,000 machine guns.

On seeing that General Hines's troops had crossed the river, the adversary yielded ground before the Second Colonial Corps, whose staff had now replaced that of our Seventeenth. Hard fighting took place on these last ramparts of the Meuse Heights south of Stenay; we had the best of it and on the Tenth the final advantage was gained. The enemy was hurled back into the plain.

This same evening, General Liggett ordered the First Army to cross the Chiers, and to gain the line MontmedyLonguyon-Spincourt-Etain.

This movement was already in process of execution when, on the eleventh of November, at I I A. M., the armistice brought hostilities to an end.

At this date and at this hour, the line of the American sector extended from Port-sur-Seille to Sedan, passing through Vandières and Bezonvaux, thence bordering the eastern edge of the Meuse Heights, continued northward through the Woevre, and rejoined the Meuse at Mouzay, followed the river up to the vicinity of Sedan where it came in touch with the right of the Fourth French Army.

The First American Corps no longer having frontal space between the corps of General Summerall and the Fourth Army was withdrawn to the vicinity of Chierry.

The booty of the First Army now included 37,000 prisoners and 850 guns. ${ }^{15}$

15 16,000 prisoners and 450 cannon taken at St. Mihiel. 9,000 prisoners and roo cannon taken during first phase. 7,000 prisoners and 50 cannon 
The American front from Seille to Meuse, near Sedan, on the eleventh of November, I9 I 8, was held by fifteen divisions of which two were French. Opposite the Germans maintained in line thirty-eight divisions often incomplete, and lapping over one another in such a manner that identification was rendered extremely difficult which proved the confusion in which the enemy's forces had been thrown.

The Americans had engaged twenty-two divisions in the operations, which we called the battle between Meuse and Argonne as well as in the fighting which took place on the right bank of the Meuse. Fifteen divisions went twice into line. ${ }^{16}$

The French coöperated in this action to the extent of six divisions, two of which went into line twice. They also furnished the artillery material, tanks, aviation, and divers rear services of which we have already spoken.

During these engagements, the Americans lost 100,000 men. Among this number many were sent to the rear for slight wounds, many for illness, as the season had been rainy, cold, and unwholesome.

taken during second phase. 5,000 prisoners and 250 cannon taken during third phase.

The American Army captured during the whole war 49,84r German prisoners and 833 Austrian prisoners (statistics of the general headquarters).

16 American divisions engaged:

First, Second, Third, Fourth, Fifth, Seventh, Twenty-sixth, Twentyeighth, Twenty-ninth, Thirty-second, Thirty-third, Thirty-fifth, Thirtyseventh, Forty-second, Seventy-seventh, Seventy-eighth, Seventy-ninth, Eightieth, Eighty-second, Eighty-ninth, Ninetieth, and Ninety-first.

Among these the following were engaged more than once:

First, Fifth, Twenty-sixth, Twenty-eighth, Thirty-second, Thirty-third, Thirty-fifth, Thirty-seventh, Forty-second, Seventy-seventh, Seventyeighth, Seventy-ninth, Eightieth, Eighty-ninth, and Ninetieth Divisions.

Seventy-eight German divisions were engaged either as a whole or in part on this same front. 


\section{The American Army in the European Conflict}

While the First Army was engaged in this constant fight, the Second Army unceasingly harassed the enemy along a wide front. From Port-sur-Seille on the right bank of the Moselle as far as the village of Fresnes-enWoevre, General Bullard multiplied his concentrations of fire and organized raids and "soundings" in order to fix the enemy and seek to know his intentions.

By November 8th, he was ready to take the offensive on both sides of the Rupt-de-Mad and to advance two brigades in the direction of Gorze and Chambley, when the order for a general attack reached him.

The high command supposed that the enemy was preparing to retreat in this region.

From the tenth to the eleventh of November (at eleven o'clock) the troops sounded the enemy from Portsur-Seille to Fresnes-en-Woevre; after a series of combats the advanced posts of the adversary were pushed back, and a resistance was encountered which prevented any serious advance.

At the extreme right of the Second Army, the Sixth Corps penetrated with its Ninety-second Division (colored) into the woods of Fréhaut, Voivrotte, and Cheminot. At the center, the Fourth Corps advanced close to the edge of Monplaisir Farm and Bonseil Wood, while, to the left, the Seventeenth Corps (French) took Butgnéville, St. Hilaire, Chateau d'Aulnoy, and part of the village of Marchéville.

During these operations several hundred prisoners were captured.

General Pershing, acceding to the request of the commander-in-chief of the French forces, had detached on October Ist two divisions in reënforcement of the Fourth 
Army. The Second and Thirty-sixth played an important part on General Gouraud's front. The Second Division, after two brilliant assaults, took the "BlancMonts," and having repulsed furious counter-attacks, carried the village of St. Etienne.

The Thirty-sixth Division relieved the Second on October 9 th, and in its first experience under fire supported a violent bombardment without flinching, subsequently participating in the pursuit of the enemy, now in full retreat toward the Aisne.

The Second Division, after operating with the Fourth French Army, was scarcely regrouped when it was again engaged upon the American front.

According to Marshal Foch's orders, two more divisions, the Thirty-seventh and Ninety-first, which had both taken part in the first attacks between the Meuse and the Argonne, were transported by rail and engaged with the two French Army Corps operating in Belgium.

The Thirty-seventh Division had scarcely detrained near Ypres when it was sent at once into battle, reaching the Escaut which was crossed in its pursuit of the enemy. As for the Ninety-first Division, it also reached the river and later penetrated in Audenarde.

To conclude our hasty enumeration of the many deeds of prowess performed by these various American divisions and to give a fair idea of America's effort on the Continent at this time, we should also give a brief account of those divisions which operated in the British lines. This narrative will be found in the tenth chapter.

The armistice surprised the American forces at the moment of success, and just as a new operation was about to be attempted.

General Pershing had proposed to Marshal Foch, who 
agreed with his view, to take the offensive between the Meuse and the Moselle, march with his First Army toward Longwy, while his Second Army should essay to reach the Briey region.

Orders to this effect had been already given.

In addition six American divisions had been placed under General Bullard's orders to prolong the right of the Second American Army on the eastern bank of the Moselle. Thus General Bullard's offensive and that which General Mangin was about to undertake with his Tenth Army in the Sarre basin would be linked.

Had the project been carried out, thanks to this concerted maneuver - the forts of Metz would have practically been invested by American troops. 


\section{CHAPTER IX}

THE MARCH TO THE RHINE

General Orders

France, November 12, I9I8.

No. 203

The enemy has capitulated. It is fitting that I address myself in thanks directly to the officers and soldiers of the American Expeditionary Forces who by their heroic efforts have made possible this glorious result. Our armies, hurriedly raised and hastily trained, met a veteran enemy, and by courage, discipline, and skill always defeated him. Without complaint you have endured incessant toil, privation, and danger. You have seen many of your comrades make the supreme sacrifice that freedom may live. I thank you for the patience and courage with which you have endured. I congratulate you upon the splendid fruits of victory which your heroism and the blood of our gallant dead are now presenting to our nation. Your deeds will live forever on the most glorious pages of America's history.

Those things you have done. There remains now a harder task which will test your soldierly qualities to the utmost. Succeed in this and little note will be taken and few praises will be sung; fail, and the light of your glorious achievements of the past will sadly be dimmed. But you will not fail. Every natural tendency may urge toward relaxation in discipline, in conduct, in appearance, in everything that marks the soldier. Yet you will remember that each officer and each soldier is the representative in Europe of his people and that his brilliant deeds of yesterday permit no action of to-day to pass unnoticed by friend or by foe. You will meet this test as gallantly as you have met the tests of the battle-field. Sustained by your high ideals and inspired by the heroic part you have played, you will carry back to our people the proud consciousness of a new Americanism born of sacrifice. Whether you stand on hostile territory or on the friendly soil of 


\section{The American Army in the European Conflict}

France, you will so bear yourself in discipline, appearance, and respect for all civil rights that you will confirm for all time the pride and love which every American feels for your uniform and for you.

John J. Pershing,

General, Commander in Chief.

In such terms did General Pershing, while thanking his troops on the morrow of the armistice, exhort them to show themselves worthy of their past record during the period which was about to begin after the German capitulation.

Would the American forces during their march toward the Rhine bridgeheads be obliged to engage in fresh combats? The hypothesis was scarcely probable. The enemy had undergone a series of costly defeats and had been in constant retreat, leaving 400,000 prisoners in the hands of the Allies.

The resisting force of the imperial armies seemed definitely broken.

The haste shown by the enemy's high command to accept the terms of the armistice of November IIth indicated that they considered their cause as irrevocably lost.

It seemed unlikely that the American advance should encounter any very severe opposition; some minor collision might, of course, occur, for the German forces were rapidly disintegrating and getting beyond their officers' control, but considering the delay which had been allowed them for their retirement, no such trouble was expected.

According to the terms of Marshal Foch's instructions the victorious armies were to halt upon the line which they had attained on November I Ith and remain there six days before continuing their forward march. 
This delay having elapsed they were to move forward and reach by two days of march a second line on which they were to remain until the twenty-first of November. Thence, proceeding by four more stages, they were to reach the boundary which separates Germany from Belgium, Luxembourg, and Alsace-Lorraine, and there await new orders.

During these successive advances, the importance of the effectives maintained in the first line, as well as the distribution of the troops in depth along the line of march, were to be determined by the breadth of front allotted to each army, the number and condition of the roads, supply facilities, etc. Orders were given each army to be prepared to assume the offensive, if necessary, within a maximum delay of forty-eight hours.

We have seen in the preceding chapter, the line attained by the American troops on the morning of November I I th. The front toward which they were directed on the seventeenth - six days after the armistice - was marked by Longwy, Audun-le-Roman, and Briey. After the 2 Ist, they were to proceed toward the front between Germany and Luxembourg. Their marching zone was bounded on the north by Mouzon, Carignan, Florenville, Jamoigne, Etalle, Habay-La-Neuve, Rodange, Grosbois, Diekirch; on the south by Thiaucourt, Chambley, Conflans, Moyeuvre, Gondringen, Thionville, Mallingen and Scheng, all inclusive. Thus almost the whole of Luxembourg and a small portion of northern Lorraine were reserved to the American contingents in the course of their march toward the German border.

No sooner had General Pershing received full instruc- 
tions from Marshal Foch, than he at once took steps to insure their execution. For the occupation of the territory evacuated by the enemy he designated the Third Army under General Dickman, whose staff, constituted since November 7 th, was at that moment at Ligny-en-Barrois. This army was to include the Third and Fourth Army Corps ${ }^{1}$ minus their artillery, and in addition the Sixty-sixth Brigade of field artillery, the Three hundred and twenty-second Field Signal Battalion, the Fifty-first and Four hundred and seventeenth Telegraph Battalions. All thése troops passed into the ranks of the Third Army at 5 A. M. on November I 7 th. General Dickman's orders were to advance, maintaining four divisions in the front line, succeeded by two others at an interval of not more than two days' march. Thus, according to Marshal Foch's instructions, the Third Army would be able, if occasion arose, to take the offensive at forty-eight hours' notice. ${ }^{2}$

The First and Second Armies were provisionally installed in rest billets.

The French troops which had, up to that time, been incorporated in the First Army were returned to the control of French headquarters on November 17 th. $^{3}$

On the eve of the day fixed for the forward march, the commander-in-chief of the allied forces completed his instructions by a supplementary note in regard to the occupation of the Rhine provinces.

1 The Third Army Corps was made up of the Second, Thirty-second, and Forty-second Divisions, the Fourth Army Corps was composed of the First, Third, and Fourth Divisions.

2 On November 22d the Third Army was reenforced by the Seventh Army Corps containing the Fifth, Eighty-ninth, and Nineteenth Divisions.

3 Seventeenth Army Corps, Second Colonial A-my Corps, Tenth and Fifteenth Colonial Divisions. 
This document specified that all troops not employed in the occupation of German territory should be maintained in Belgium, in Luxembourg, or in Alsace-Lorraine. A portion of these forces were, however, to remain ready to march at a moment's notice, and penetrate into German territory at the slightest alarm. It was also prescribed that the American contingents should be kept up to a minimum force of ten divisions and should be stationed beyond a line marked by the river Meuse as far as Mezières, then the road Mezières-Hirson-Maubeuge. The territorial zone in Germany which was assigned to the American troops was bounded on the north by the limit separating the districts of Coblenz and of Trèves, from those of Cologne and Aix-la-Chapelle ${ }^{4}$; and on the south by the line Sierck-Taben, on the Sarre, Frommersbach, Rheinsfeld-Thalfang, Marbach, Kirchberg-Simmern-Rheinböllen-Heimbach-on-the-Rhine. ${ }^{5}$

The bridgehead of Coblenz was to be held by an army corps. In the rear two army corps of two divisions each were to remain in reserve, hold the intermediary passages on the Rhine, and assure the occupation of the country.

Finally, in the American zone, an army corps composed of two divisions was to be billeted in the region of Trèves.

The orders of the marshal commander-in-chief, distributed the duties incumbent on each of the Allies proportionately to their effectives. He, however, requested the Belgians and Americans to furnish to the troops of

4 This line is marked approximately by Lammersweiller, Manderfeld, Kronenburg, Rheinbach, and Oberwinter.

5 Sierck allotted to the French troops, the other localities to the Americans. 


\section{I 2 The American Army in the European Conflict}

occupation a more important contribution than had been asked of the French and British armies, on account of the forces which these latter were obliged to maintain in other theaters of war.

Such were the general plans for the occupation of the territory vacated by the vanquished foe.

An important modification was shortly to be made, however, in these arrangements. The lack of discipline which had been apparent for some time in the ranks of the German services of the rear reached more serious proportions near the front; in many units the officers had quite lost control over their men, and it seemed probable that the numerous deserters and stragglers from the retreating armies might provoke scenes of disorder in the evacuated regions, during the time still to run between the departure of the last German troops and the arrival of the first allied contingents. The German command itself here solicited the intervention of the Allies in order to obviate this danger. On the eighteenth of November, Marshal Foch, after an understanding to this effect with the adverse command, authorized his armies to penetrate at once into the evacuated territory, leaving, however, between their advance guards and the rear of the retreating armies a minimum distance of six and one-half miles. This change of plan, which authorized our armies to accelerate their advance, in no way permitted them to retard it.

On November I7th, at 5.30 in the morning the advance guards of the Third Army crossed the line defined by the armistice, on the entire front.

The march was effected so that a rapid deployment was possible, in case of any alarm or untoward happening.

On the right the Fourth Corps (General Muir) main- 
tained in first line the Third Division (General Brown), and the First (General Parker). The Fourth (General Hersey) was held in reserve.

On the left the Third Corps (General Hines) marched in a similar formation, the Thirty-second Division (General Hahn), the Second Division (General Lejeune) in first line and the Forty-second Division (General McArthur) in support.

The first stage of this march was marked by absolutely no untoward incident, nor was any enemy detachment encountered; the rear guards of the vanquished army were already distant. The following days passed in the same manner. In the course of their march toward the Rhine the Americans found the country entirely freed from enemy troops in conformity with the provisions of the armistice. We may therefore limit ourselves to a mere mention of the stages of the Third Army's advance.

On November 2 Ist General Dickman's troops at three in the afternoon, occupied the city of Luxembourg, and. the grand duchy was crossed in the same order as has been hitherto indicated; after the Twenty-second the Seventh Corps, ${ }^{6}$ which was then part of the Third Army, followed in the traces of the first-line corps.

The Eighty-ninth Division followed the Fourth Corps, the Ninetieth behind the Third.

After the completion of this stage the Third Army, on November $23 \mathrm{rd}$, edged the entire frontier between Luxembourg and Germany and there rested, the first phase of the march toward the Rhine over friendly and neutral territory being thus terminated.

6 Reduced to two divisions, the Eighty-ninth (General Winn) and the Ninetieth (General Allan) as the Fifth (General Ely) had been employed on construction work on the line of communication. 


\section{The American Army in the European Conflict}

On the morning of December Ist the occupation of the German territory was to begin.

The Third Army ${ }^{7}$ crossed over into the German Empire, one of its columns traversing the very bridge at Wasserbillig where in August, I9I4, the first troops of the Eighth German Corps had entered the Luxembourg territory.

The same day the Americans occupied Trèves, and during the following days the advance continued without changes, two army corps being maintained in the first line with one in reserve.

The headquarters of the army of occupation, at first stationed at Luxembourg, now moved to Bitburg, while General Pershing established at Trèves an advanced post of command. On December 7 th, a battalion of infantry was sent forward by rail to Coblenz in order to keep order in that town. On the eighth the first cavalry patrols arrived on the Rhine at Remagen; on the tenth the Third Army reached the river upon its entire front. The headquarters, removed from Bitburg, were now established at Mayen. There remained only for the Americans to take possession of the bridgehead at Coblenz.

This Coblenz bridgehead included an arc of a circle whose radius was some nineteen miles, having as central point the eastern end of the Pfaffendorf bridge. On this line the advance posts were to be established.

We have already seen that on December ist two French divisions were temporarily attached to the Third Army in order to participate in the occupation of the Coblenz bridgehead. The units in question were now

7 Reënforced temporarily by two French divisions, the Second (Chasseurs à pied), and the Forty-eighth Infantry Division, assigned to the Third Corps. 
placed to the right of the American line, and it was natural to join them to the French Tenth Army now occupying the neighboring zone. This was done on December I 2th. Thus the American sector was somewhat narrowed, its southern limit being formed by the administrative frontier line separating the districts of Berncastel, Wittlich, Cochem, Mayen, Coblenz, and Westerberg from those of Wimmern, Zell, St. Goar, St. Goarshausen, Diez, and Limburg.

On the thirteenth of December at 7 A. M., the Third Corps, designated to occupy the bridgehead itself, sent its first elements across the Rhine and pursued this operation during the following days without the smallest incident. On the sixteenth the American advance posts were established along the exterior circumference of the bridgehead, with the corps headquarters fixed at Neuwied. ${ }^{8}$

On the left bank the Fourth Corps ${ }^{9}$ with headquarters at Cochem on the Moselle, was stationed in support. Further rearward, the Seventh Corps ${ }^{10}$ with headquarters at Grevenmacher, was placed in reserve near Trèves.

The army headquarters were now transported from Mayen to Coblenz.

On December I 7 th, the occupation of the enemy territory, as it had been foreseen and laid down by the armistice conventions, was, in so far as the Americans were concerned, completely terminated. The zone of the rear, occupied by the Third Army, ceased at the Luxembourg frontier, and the troops stationed in the territory of the

8 Now formed with the First, Thirty-second, and Second Divisions.

9 Now formed with the Third, Fourth, and Forty-second Divisions.

10 Reënforced by the Thirty-third Division under General Bell from December 12th. The artillery of the army included the Fifty-fifth, Fiftyeighth, Sixty-sixth, One Hundred Fifty-eighth, One Hundred Sixty-fourth field artillery brigades. 


\section{The American Army in the European Conflict}

grand duchy were attached, for administration and for instruction, to the Second Army whose headquarters were at Toul.

In the entire course of their march on German territory the American troops never encountered an enemy detachment, but, in order to complete the account of their doings, it is necessary here to say a word about their relations with the civil population in the occupied regions.

On first entering Germany, the American soldier was indeed somewhat astonished by the warm welcome which he received. Knowing the Germans by what he had seen of them on the field of battle and by the atrocities he had read of and heard recounted, as well as by the far from flattering portrait given him by his chiefs, he was now surprised to find himself in a country, not as he had been led to suppose, torn by revolution and civil discord and on the brink of starvation, but in a land of comparative plenty, among people of amiable appearance, exceedingly submissive to all orders, and even anticipating his wants. Order reigned everywhere. In the villages, when the troops passed, the civilians lined up to watch them defile, showing, especially the women and children, quite a friendly curiosity in their movements.

The line of conduct which the Germans had traced for themselves was simplicity itself.

The burgher intended to show himself as pleasant and cordial as possible, in the hope of obtaining thereby the benefit of a very lenient occupation.

With that spirit of discipline which has always characterized the masses in Germany, every one worked to keep up this tacit understanding, and endeavored to the 
best of his ability, individual and collective, to fructify various more or less clever schemes for "fraternization."

In the long run these attempts met with absolutely no success.

In the first place, it was impossible for the German civilian to sustain for a long period the part he had chosen to assume; the bitterness of his hate and disappointment soon made themselves felt, resistance was made to certain necessary requisitions, and in the towns, the American officers were frequently lodged in a most inferior manner. This sudden change of front sufficed to open the eyes of the few who had allowed themselves to be deceived by the first friendly demonstrations, under which it was easy to perceive a hypocritical attitude, and the American who has a natural contempt for the man who voluntarily humiliates himself before his adversary was unfavorably impressed with what he, day by day, observed. Relations between the two nationalities became less and less frequent.

The Third Army issued stringent orders against fraternization of any sort, the different brigades and divisions followed suit. According to the rules prescribed, communications between the soldier and the citizen were to be limited strictly to business and to the service and, in order to reduce even such direct dealings there was established in each unit - division brigade or regiment - a special bureau of civilian affairs to treat with the population of the occupied regions. In this way no officer or trooper had occasion to address himself directly to enemy civilians.

On the other hand, the soldier's day was taken up by such a complete program of instruction that little time 
was left for anything but the work laid down for him to do. It is an ungrateful task to attempt to occupy the time of a soldier who has just been making war, but it was one of which the American officers acquitted themselves with rare tact.

The programs had a double object; to keep the troops well in hand, and at the same time prepare them for a return to civil life. Many schools were created with this object in view. Even in the regiments, enough instructors were found to give courses in applied mechanics, electricity, telephone and telegraph service, history and modern languages. Thus the American combatant who has been through the war comes out of it not only with his experience wonderfully enlarged, but also with his general instruction greatly improved over what it was upon entering the army.

The great benevolent societies which we shall describe elsewhere took a prominent part in the education of the soldier and did much to keep him, while occupying German territory, away from the unwholesome influence of enemy propaganda. The Red Cross, the Young Men's Christian Association, the Knights of Columbus, and the Salvation Army all established comfortable clubs which the men of the occupation forces regularly frequented and where they found amusements, dances, theatricals, and lectures to keep them among their own compatriots.

Thus, in mid December, I9 I 8, our American associates had concluded without the slightest hitch, and within the specified time, the occupation of the German territory allotted to them.

Solidly established on the right bank of the Rhine, and disposing of powerful effectives which would have made it 
possible at a moment's notice to take up arms, the American soldiers quietly prepared to resume the occupations of peace time, equally ready to plunge once more into active operations at the first alarm. 


\section{CHAPTER X}

PART TAKEN BY AMERICAN UNITS IN THE OPERATIONS ON BRITISH FRONT - AND IN SECONDARY THEATERS OF THE WAR

IT was perfectly natural, the British navy having generously come to the aid of the Americans in order to facilitate their arrival in Europe ${ }^{1}$ that at the moment of the enemy offensive toward Amiens, certain units should be sent into this threatened area rather than to points of the French front. These divisions, while training at the rear and in some of the quiet front sectors, would serve to augment the density of the troops and at the same time strengthen the resistance.

General Pershing arranged with the British authorities that ten divisions should be thus distributed in the British cantonments, maneuver and training camps, and subsequently trained for trench warfare at the front pending the day when they would be regrouped and become a part of the great American Army.

These divisions; the Fourth, Twenty-seventh, Twentyeighth, Thirtieth, Thirty-third, Thirty-fifth, Seventy-seventh, Seventy-eighth, Eightieth, and Eighty-second, arrived in France at the end of April during the month of May and in the first days of June, I9 8.

No sooner were they disembarked than their training began. The program of instruction had been drawn up

148.5 per cent. of the effectives disembarked in Europe were carried overseas by British tonnage. 
by the American general headquarters at Chaumont. They differed slightly from those imposed upon the troops who were assembled in the American zone.

It had been necessary to modify the American regulations slightly considering that these new contingents, and in particular the infantry, were armed with English equipment. For it was with the British army rifle and machine gun that these American divisions made their first essay in arms.

It was also imperative to take into account the very special situation in which the British Army found itself at this moment from the point of view of its organization. After the German attacks of March and April our allies were obliged to suppress one battalion out of three in many of their brigades. Besides, in several divisions the infantry had been withdrawn. These units lacking troops kept their officers, their services, their trains, and found themselves at rest awaiting the arrival of reënforcements. They were called "Cadre Divisions."

Thus, when the American units arrived in the British zone to perfect their training, the services and transportation facilities of these Cadre Divisions were at once turned over to the American divisions. The one possessed all that was lacking in the other. The name given by the British to such units working side by side and completing one other was "Affiliated Divisions."

During these periods of instruction the British officers without troops were placed near the American officers of the same rank and served as "text-book," according to another of the British expressions.

As soon as the American troops were pronounced fit for sector duty, it was decided to send them into line by battalion, and this measure would have permitted the 


\section{The American Army in the European Conflict}

British brigades to recuperate their missing third battalion.

This primary phase being terminated, the American battalions were to have been returned to their own regiment, and these units also were then to pass a certain length of time in the front line. As a matter of fact it was impossible to realize this program, at least for the ten divisions in question.

When the enemy broke through our lines along the Chemin-des-Dames and advanced toward ChâteauThierry, it seemed prudent to post between Paris and the front the Fourth and Twenty-eighth Divisions, ${ }^{2}$ and to send into the quiet sectors of Lorraine and the Vosges, the Thirty-fifth, Seventy-seventh, and Eighty-second Divisions in order that they might relieve French units, thus rendering these trained troops available for action.

When these movements had been effected, there remained only five American divisions in the British zone. These units went into service at the front on the following dates:

The Twenty-seventh on July 22 nd.

The Thirtieth on July I6th.

The Thirty-third on July 3 rd.

The Seventy-eighth on August I 2 th.

The Eightieth on July 22 d.

The commander-in-chief, in an order dated June $25^{\text {th, }}$ had organized the Second American Army Corps and had placed General Read at its head. Fruges became the headquarters of this new corps, whose mission was to administer the American divisions scattered in the British zone, to superintend their instruction awaiting the day -

2 See Chapter IV, the rôle of the Fourth and Twenty-eighth Divisions during the spring defensive. 
which was now approaching - when the corps would assume the direction of tactical operations.

During the last week of August, General Pershing directed the Thirty-third, Seventy-eighth and Eightieth Divisions to proceed by rail to the American zone, having decided to utilize these units for the general offensive which he was contemplating in the autumn. During their training in the British zone these divisions had had but a single chance to accustom themselves to trench warfare. But they had nevertheless been able already to signalize themselves in a way which called forth the admiration of their British comrades for the courage and audacity which they had there displayed.

The Thirty-third Division, in particular, had brilliantly distinguished itself.

On Independence Day, July 4th, one of its battalions, joined with some Australian troops, participated in a raid near Villers-Bretonneux which was remarkably prepared and carried out. I,400 prisoners were brought home, and these acknowledged having been so completely taken by surprise that they had not even been able to snatch their muskets.

One of the British generals present in this affair confided to us that the original thousand Americans forming the assault battalion had been greatly augmented by the impromptu enlistment of a quantity of "Sammies" who, posted in the second line, could not resist the temptation of joining their comrades which they had been able to do by carefully evading the vigilance of their chiefs.

The departure from the British front of the three divisions which we have enumerated left to the second American corps, operating at Fruges, the Twenty-seventh and 


\section{The American Army in the European Conflict}

Thirtieth only. General Read then assumed command of these divisions. ${ }^{3}{ }^{4}$

During July, I9 I 8 , these two divisions were to be found in the first line, engaged totally or in fractions before Poperinghe, ${ }^{5}$ Ypres, ${ }^{6}$ Lake Dickbusch, ${ }^{7}$ Voormezeele, ${ }^{8}$

${ }^{3}$ In the course of the operations in which the Twenty-seventh and Thirtieth Divisions participated, they were incorporated in the ranks of the Second British Army. Thus the staff of the American corps exercised over them only administrative control.

4 ORDER OF BATTLE OF THE SECOND ARMY CORPS

Major-General G. W. Read commanding the corps

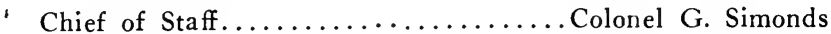
Chief of First Section (G-r) ........... Colonel R. K. Hale Chief of Second Section $(\mathrm{G}-2)$...........-Col. K. T. Riggs Chief of Third Section $(\mathrm{G}-3) \ldots \ldots \ldots \ldots$ Col. F. E. Buchan Chief of Fourth Section $(\mathrm{G}-4) \ldots \ldots \ldots$ Col. H. S. Herrick

Twenty-seventh Division

Major-General J. F. O'Ryan commanding the division Chief of Staff: Colonel Stanley H. Ford

53d Infantry Brigade

Col. G. M. Andrews

105th Infantry Regiment

Major C. W. Berry

1obth Infantry Regiment

Col. W. A. Taylor 54th Infantry Brigade Brig.-Gen. P. E. Pierce Iozth Infantry Regiment Col. C. T. de Bevoise 108th Infantry Regiment Col. E. S. Jennings

Thirtieth Division

Major-General E. M. Lewis commanding the division Chief of Staff: Lt.-Col. J. K. Herr

59th Infantry Brigade

Brig.-Gen. L. D. Tyson

II th Infantry Regiment

Col. C. F. Spence

118th Infantry Regiment

Col. O. R. Wolfe 6oth Infantry Brigade

Brig.-Gen. S. L. Faison

IIgth Infantry Regiment

Col. J. Van B. Metts

I2oth Infantry Regiment

Col. S. W. Minor

5 Twenty-seventh Division totally engaged from July 9th to August 2oth.

6 Thirtieth totally engaged from July 17 th to August 9th.

7 Twenty-seventh totally engaged from August 2 ist to August $30 t h$.

${ }^{8}$ First brigade of the Thirtieth Division engaged from August 3 rst to September $2 \mathrm{~d}$. 
The Lankhof Farm, ${ }^{9}$ and the heights of Vierstraat. ${ }^{10}$

When these operations were brought to a close the Twenty-seventh and Thirtieth Divisions which had counted in the ranks of the Second British Army returned to General Read's command.

The Second American Corps had been designated to take part in the offensive of the Fourth British Army. The mission of General Rawlinson consisted in exerting pressure upon the enemy's front between Cambrai and St. Quentin, and it may be remembered that toward the middle of September the progression of Rawlinson's army which, working in conjunction with the French left wing, followed the line of the Somme Valley had arrived at the Hindenburg Line, where it met with obstinate resistance.

Here the enemy occupied a position along the edge of the St. Quentin Canal. Near the environs of Bellicourt and between this village and Vendhuille - that is to say, on that part of the front held by the Australian corps this canal passes under a tunnel six kilometers long.

The second American corps was placed at the disposition of General Rawlinson, on the twenty-first of September, that it might aid in the taking of that portion of the enemy line which it appeared would be fiercely disputed.

The British general conceived the following plan for the employment of his own élite troops, and also of the American infantry which before long was to show itself equal in courage and daring to the Australians. General Read's soldiers were to alternate with those of General

9 First brigade of the Thirtieth Division engaged from August 3 Ist to September $2 \mathrm{~d}$.

${ }_{10}$ Numerous elements of the Twenty-seventh Division engaged from August 3 rst to September ist. 
Monash for the conduct of the fight, the initiative of which was to be left with the Americans.

The Second Corps commander placed his divisions side by side, the Twenty-seventh at the left, the Thirtieth at the right, and moved them on September 27 th fronting their objectives. Their mission was to seize the first Hindenburg Line, and after, to storm the villages of Nauroy and Gouy. As soon as the German line was broken, General Monash with his Australians was to pass through the American lines and exploit this first success.

From the twenty-second to the twenty-ninth of September preliminary operations were undertaken with the object simply of establishing the first attacking lines on a solid basis.

On the twenty-ninth the attack was launched. A heavy fog favored the surprise, helped in the tank action, but rendered very difficult the mopping up of the battle-field, back of the first assault waves. For the ground especially that which the Twenty-seventh Division was to traverse bristled with defenses of all kinds. The trenches were deep, ditches and sunken roads, cleverly concealed by camouflage, crossed it in every direction. The enemy made use also of subterranean passages in order to reach the tunnel of which we have spoken and which served them as a strong position for the concentration of troops.

While the assailant was precipitating himself upon the successive objectives his adversary remained concealed under ground while the wave broke, then leaped forth and engaged, under cover of the mist, in a confused hand-tohand combat. The Twenty-seventh Division was unable to attain its objectives that day on account of these obstacles. On the other hand, the Thirtieth Division, whose way led them over a less difficult and cut-up region, 
not only succeeded in gaining the Hindenburg Line, but went beyond, taking the position Le Catelet Nauroy.

On September 3 oth, according to plan, General Monash, at the head of the Australians, went through the Second American Corps, and completed the mopping up of the battle-field. But the work of General Read's men was not yet finished. A short breathing spell only was accorded them before they, in their turn, replaced the Australian division.

The sixth of October found the Americans again in line, the Thirtieth Division in contact with the enemy on an advanced position west of Montbrehain.

Continuing the offensive these valiant troops pursued their success up to the Selle, where they encountered a powerful resistance, and the Twenty-seventh came to their aid. At this moment the Second Corps found itself placed at the extremity of a salient which bit into the enemy line to a depth of twenty-five kilometers. Progress continued nevertheless and, after a good artillery preparation, the Thirtieth Division succeeded in forcing the line of the Selle. On October 2oth the vicinity of Catillon was attained where the ground occupied dominates the Sambre Canal. Here the Twentyseventh Division at the left was deployed along the St. Maurice River, linking the Americans with the Thirteenth Army Corps at Bazuel.

These fine American divisions, whose aid had been extremely valuable to the allied cause, had suffered greatly during these combats. Losses were heavy; more than 8,000 men had been evacuated in the course of the fighting and 2,225 dead were left on the field.

The Second Corps had helped to penetrate the Hindenburg Line at one of the vital points where it was the most 
strongly organized and had even carried the fight far forward into the enemy's ground, on an average front of 5,500 yards. It had advanced sixteen miles, capturing the villages of Bellicourt, Nauroy, Brancourt, Prémont, Busigny, Rocquigny, Escaufort, St. Souplet, St. Martin, Ecaillons, Ribeauville, and Mazinghem. A large amount of booty was taken; 6,000 prisoners of whom I 50 were officers, 73 field guns, 9 heavy guns, 400 machine guns, a complete train on rails, and supplies of all sorts.

The Second Corps had taken an active part in this advance between Cambrai and St. Quentin, causing the liberation of these two towns a few days later.

General Rawlinson hastened to congratulate General Read on the prowess of his divisions, and when the plan of the operations had entirely been realized the American general was able to communicate the following flattering appreciation of their services to his men. The first was a telegram from their own chief, the second from the British high command.

"The commander-in-chief desires you to convey to the officers and soldiers of your corps his appreciation of the magnificent qualities which have enabled them, against powerful resistance, to advance more than ten miles and to take more than 6,000 prisoners since September 27th."

Field Marshal Sir Douglass Haig expressed himself in the following terms:

October 20th.

I wish to express to you personally and to all of the officers and men serving under you, my warm appreciation of the very valuable and gallant services rendered by you throughout the recent operations with the Fourth British Army. Called upon to attack positions of great strength held by a determined enemy, all ranks of the Twenty-seventh and Thirtieth American Divisions under your command displayed an energy, courage, and determination in attack 
which proved irresistible. It does not need me to tell you that in the heavy fighting of the past three weeks you have earned the lasting esteem and admiration of your British comrades in arms whose successes you have so nobly shared.

The Thirtieth Division was withdrawn from the sector the night of October I9-20th; the Twenty-seventh was relieved the following night.

The Second American Army Corps was in turn withdrawn from the front, leaving the ground to be guarded by the Ninth and Thirteenth Army Corps.

Entrained at Roisel, these two divisions went, the Twenty-seventh to Corbye, the Thirtieth to Querrieu, where they were to be reënforced and to continue their military training.

But before the conclusion of this period of instruction and of rest, the armistice was signed.

On November 19th the Second Corps with its constituent divisions, was transferred to Le Mans, there to await embarkation orders for America.

In compliance with a request from the Italian Government, the commander-in-chief of the Expeditionary Forces detached from the Eighty-fourth Division, the $33^{2}$ Infantry Regiment, which was placed at the disposition of General Diaz.

The regiment arrived on October 29th at Treviso; on the thirty-first, when the enemy was in retreat it reached the left bank of the Piave. On the third of November, arriving at the Tagliamento, the regiment took contact, through its patrols with the enemy's rear-guard and organized along a four-mile front the bridgehead of Ponte della Delizia. November 4th capturing Codroïpo on the 


\section{The American Army in the European Conflict}

Udine road, it seized upon important stores and supplies which the enemy had been obliged to abandon. After assisting at the disarmament of the Austrian forces, the 332 nd by a rapid march reached Ipplis on the seventh and there was dislocated. One battalion was directed to Cattaro by way of Venice, the two others were sent to Cormons (Austria). On November 17 th one of the two battalions garrisoned at Cormons was detached and sent to Fiume.

The Expeditionary Forces detached for operations in Russia with the allied contingents the 339th Infantry Regiment, a battalion of engineers, a field hospital, and a field ambulance. These troops, which numbered in all about 4,800 men, embarked on August 26th at Newcastle, and operated with the force of 29,000 French and British in the region of Arkangel.

Together with the Allies they mounted the river Dvina, attaining Shenkursk, which they occupied for a time but where they were unable to maintain themselves.

The twenty-fifth of January, I9 I9, our combined forces, attacked by Red troops much superior in number, were obliged to withdraw as far as the junction of the Vaga and Dvina rivers. There they seem to be solidly established protecting the base port of Arkangel as well as that of Murmansk with which they remained linked by rail and from which they drew their supplies. 


\section{CHAPTER XI}

DEVELOPMENT OF THE LINES OF COMMUNICATION ORGANIZATION IN AMERICA - SEA TRANSPORTATION - GROWTH OF THE SERVICES OF THE REAR IN FRANCE - DIRECTOR GENERAL OF TRANSPORTATION - MOTOR TRANSPORT SERVICE - MILITARY BOARD OF ALLIED SUPPLY

"ALL the Fighting is not done at the Front" was an inscription which might be frequently seen on placards hung upon the walls of the various offices of the services of supply.

In fact from April, 1917, to November, 1918, American services of the rear had been waging incessant war against the tremendous difficulties of every kind entailed by the huge distances to be covered, the initial unpreparedness, and the element of danger supplied by the German submarines during the crossing of the Atlantic.

In a preceding chapter we have endeavored to convey to our readers some idea of the complex and difficult problems with which the authorities of the United States were confronted. We have seen that the five main services which had administered America's army in peace time had set themselves to work without delay. Powerful help had been given by the voluntary coöperation of a great number of prominent men of business, manufacturers, bankers, engineers, scientists, who put their technical knowledge and their experience of great commercial enterprises at the disposal of their government. 


\section{The American Army in the European Conflict}

In the space of a few weeks the War Department had placed upward of 60,000 contracts, requiring thousands of tons of raw material and employing hundreds of thousands of workmen. New manufacturing plants were erected; at the same time immense services intended for the reception, distribution, and transportation of supplies and material were being organized.

The setting on foot of a great system of war manufactures had been most difficult; factories became quickly congested with orders from divers ministerial departments that came in pell-mell in competition not only with one another but also with those of the allied governments. Shortage of raw material was acutely felt almost everywhere, and the establishment of some order of priority soon became necessary. The Council of National Defense was utilized as a clearing house for dealing with these problems, and later the War Industries Board was formed. There, representatives of the Army, Navy, and other departments met with delegates of the manufacturers and settled particularly knotty points as they arose. As problems of this type became more complex, and as the War Department bureaus began to get their work more in hand, centralization of the purchasing mechanism of the army became both desirable and possible. This was done in February, 1918, through the creation, as part of the General Staff, of two important sections. One, that of "Purchase and Supply," was charged with the purchase of all material, equipment, and supplies required for the needs of the army.

The other, called "Division of Storage and Traffic," controlled the storage of all supplies and furthermore was in charge of military sea or land transportation. On April I 6th these two sections were united and placed un- 
der Quartermaster General Goethals, the builder of the Panama Canal, under the title of Director of Purchase, Storage, and Traffic. He had absolute control of all American Services of the Rear, from the production centers in the United States to the European ports of debarkation on the Atlantic.

During a period of particularly intense activity, for a few months beginning May, i9 18, Mr. Edward R. Stettinius, of J. P. Morgan \& Co., well known to the allied governments for the services he had rendered in organizing their system of purchases in the United States, served as Second Assistant Secretary of War with general supervision over the purchasing functions of the War Department.

Under such management, the organizations established in the United States were not long in reaching a high degree of efficiency, and in the first months of I9 I 8 constantly growing streams of men and material flowed into the ports of embarkation.

Thanks to energetic action on the part of the Shipping Board and of its section for the control of tonnage, the number of ships available for the crossing of the Atlantic considerably increased. As has already been said the German ships that had been seized in the American ports had been put into service in the fall of I9I7. In February, I9I8, the Shipping Board had purchased seven British transports. By the end of March, the German drive which placed the Allies in such a perilous position, convinced them that the moment had come for drastic measures. The British Government lent all the transports it could dispose of. The American War Trade Board absolutely prohibited all non-essential importations. Eighty-seven Dutch boats heretofore idle in 


\section{The American Army in the European Conflict}

United States ports, with a total deadweight of 533,000 tons, were requisitioned; in the course of the summer important quantities of Japanese and Scandinavian shipping was chartered.

To conclude, the output of the new American shipbuilding yards began slowly to make itself felt. At the time of the armistice there existed three hundred and forty-one of these yards with a total of I, 284 launching ways; more than double the number existing in the rest of the world. On November I, 1918, the army had in service a fleet of its own consisting of 39 troop ships, 38 animal transports, I 8 refrigerator ships, 228 cargo ships, and 4 tankers. In addition, General Pershing had gathered in Europe a cross-Channel fleet which numbered 104 vessels averaging 3,000 tons. By adding to these figures those of the vessels lent by the Allies, we will find that, at the time of the armistice, the American Army had shipping either in operation or under definite allocation totalling 3,800,000 tons deadweight, a fleet twice as large as the entire American merchant marine engaged in foreign trade when the war began.

While the number of boats was thus augmenting the time employed for the round trips decreased as a direct consequence of the improvements in the operation of the ports. From February I, I9I 8 , to the armistice the troop ships, including the slower vessels, averaged under forty days for a complete circular trip. The faster ships averaged under thirty days; during the summer the Leviathan, former Vaterland, and the Mount Vernon, former Kronprinzessin Cecilie, averaged under twentyseven; The Great Northern and Northern Pacific averaged respectively twenty-five and twenty-six days, and have each made the round trip in nineteen days. During 
the whole summer the Leviathan landed American troops in France at the rate of over four hundred men a day.

The round trip voyages of the cargo transports which are much slower and carry large amounts of freight which is difficult to handle, were naturally effected less rapidly. These ships, nevertheless, during the spring and summer of I9I 8 maintained an average of seventy days. When it is remembered that these results were achieved by vessels which were compelled to navigate in convoys and to wait for escorts, it will be readily seen that there was no slackness in the ports on either side of the Atlantic during the decisive months.

To mention the American ports only: New York, during the fall, shipped to the Expeditionary Forces a monthly average of 400,000 tons of freight, and did so with a normal detention in port for the large army cargo transports of only fifteen days. Newport News had been developed to such a point that at the time of the armistice, cargo to the extent of 150,000 tons a month and animals to the number of 20,000 a month were shipped from this port.

Baltimore and Philadelphia shipped, respectively, 80,000 tons a month.

The first convoy of troops left America for France in June, I9I7. In July and August few men were embarked, but from September on, in consequence of the entry into service of German shipping, the rate of troop transportation seriously increased and reached 50,000 men in December. By February, I9I8, a total of I 95,000 had been attained. In March, shipment for this month alone was 84,000 . But at that time, the German armies, having assumed the offensive, there was a great demand for American infantry; the British 


\section{The American Army in the European Conflict}

Government furnished many ships for this purpose. Transports were loaded fifty per cent. in excess of their normal capacity. From this time on the monthly rate of embarkation increased by gigantic leaps - I I 8,500 men in April, 246,000 in May, 278,800 in June. Before the first of July I, 000,000 men had been transported. The July record exceeded all expectations, the number of troops embarked being 306, I85, and before the end of October the second million had sailed from American shores. During the four months of May, June, July, and August I 21,703 men were embarked. When the armistice was signed the total embarkations amounted to 2,076,000.

Out of this number, 49.9 per cent. was transported by British shipping; 43.7 per cent. by American, 6.4 per cent. by French Russian, and Italian shipping. In the words of Secretary Baker, "Never had such a troop movement been contemplated." This achievement wrought a decisive effect upon the world's history, at one of its most crucial moments.

If we turn to the question of cargo movement, taking into account only the shipments made from the United States, we find that the figures were low at the beginning; 16,000 tons in June, 1917, I2,000 in July, 19,000 in August. From that time on, under the influence of measures taken to increase the number of vessels, a sharp ascending movement began, which continued regularly so that, in October, 19I8, the monthly rate of transatlantic transportation was 636,000 tons. The total monthly transatlantic and cross-Channel tonnage discharged during the two highest months was 9II,000 and 913,000 tons.

Almost all of the 5, 150,000 tons of freight transported 
from America to Europe before the armistice was carried in American bottoms, and less than 5 per cent. was lifted by allied ships. It may be interesting to quote here, from the report of Secretary Baker, some information concerning the material in question. It included among other items I, I 45 consolidation locomotives of the IOOton type, of which 350 were shipped already set up on their own wheels, so that they could run under their own steam a few hours after having been unloaded onto the tracks by the powerful hoisting machines of Brest and St. Nazaire. This is the first time that the annals of maritime transportation have recorded the voyage of locomotives of such size entirely mounted. Special vessels with extra large hatches were withdrawn from the Cuban ore trade for this purpose. In the meantime, the hatches of other ships were specially lengthened so that on the day of the armistice the military authorities were prepared to ship these engines at the rate of 200 a month. By that time, the number of standard-gauge freight cars imported from America to France for the A. E. F. amounted to I 7,000 of the 33-ton type; that is to say, with a carrying capacity of $5 \mathrm{I}$,000 cars of the French IO-ton type.

Although this enumeration may appear somewhat lengthy it is indispensable to give an idea of what was accomplished in transportation. Indispensable, but inadequate - for with results obtained we must also take into account those which were in process of formation and on the point of becoming effective when hostilities were suddenly brought to a close. In November, 1918, the sea tonnage at the disposal of the A. E. F. was increasing at the rate of half a million tons a month. The output of the shipbuilding yards had become so enormous that, by the spring of I9I9, it was hoped that all boats bor- 


\section{The American Army in the European Conflict}

rowed from the British merchant service might be restored: and before the end of the summer, the United States expected to be themselves in a position to lend to England a like amount of shipping.

At the close of the war the diagram of monthly transportation of freight from America to France was still on the ascending curve; the increase in the number of available ships combined with the decrease of submarine danger fully justified the assertion that the program of an Expeditionary Force of eighty divisions would certainly have been entirely carried out in a short time.

Every one had his share of glory in obtaining these magnificent results.

The American departments which organized a formidable system of war manufacture, of transportation and supply, which succeeded in finding ships when it seemed quite impossible to discover any, and which, in ever-increasing numbers, embarked upon these vessels men and material in enormous masses; the navy which, at the cost of immense efforts, was able to cut down to an almost insignificant figure the losses inflicted by German submarines upon the American Expeditionary Forces; the British, who transported on their ships almost half of these effectives; the French finally, who came in for a large share of praise by the manner in which their ports and railroads responded to the demands which many experts supposed to be impossible after forty months of war; this brings us to the question of organization in France.

When General Pershing at the beginning of the war decided that the direction of his services of the rear would be for some time located at the Chaumont headquarters, 
he counted, as has been previously mentioned, upon leaving them there for as short a time as possible.

With the constant increase in the numbers of the Expeditionary Forces, and the development of their organizations, questions of supply became more and more complicated and called for an ever-growing personnel. The network of American activities by degrees covered the entire territory of France, and it became urgent to take advantage of local resources of all kinds.

On December I 4th a new base section had been established in Great Britain. On account of great distances involved it now became imperative to locate the central direction of this network not at the extremity of the line, but in its very center. On January 15 th it was transported to Tours. From here its activities extended over the whole of France and of Great Britain. Its proportions were those of a ministry such as might have been formed had we combined our French departments of War, of Public Works, and of Transportation. The offices entirely filled three large barracks which the French Government had placed at the disposal of the Americans. From one of these offices the general commanding the service of supplies controlled the enormous organization charged with meeting the requirements of the Expeditionary Forces. ${ }^{1}$ Under his immediate orders he had a staff and several departments. The staff consisted of three sections :

The First Section exercised delegated authority over all matters of organization administration, and the procuring of personnel and material from both the United

1 General Kernan controlled the service of supplies up to the end of July, 1918, at which date he was replaced by General James G. Harboard, who commanded the S. O. S. up to the end of the war. 
States and Europe. It disposed of two powerful agencies; the sea tonnage and the General Purchasing Board. Notified every month by the Shipping Board at Washington of the quantity of shipping available for the succeeding month, it distributed it among the divers services in proportion to their wants and in the measure in which they had been unable to meet those needs by purchase on the European markets.

The Second Section, far less important, controlled all questions of intelligence and information counter-espionage, and postal censorship.

The Fourth Section, for there was no third section, had a general surveillance over all questions of construction, transportation, and supply, took charge of men, animals, and material at the time of their debarkation or, in what concerns the two latter, at the time when they were acquired by the American Army through purchase in Europe. From that time on, this service was responsible for their housing and storage in the camps, barracks, depots of all kinds whose establishment it also supervised, as well as of their transportation by rail, roads, or canals to their ultimate destination. It was responsible for the reception and billeting of troops upon their arrival in Europe. On French territory it directed all labor units, finally it controlled the salvage and remount service.

These three sections, of course, kept in constant touch with the corresponding sections of headquarters at Chaumont.

Such was the organization which assumed the heavy task of coördinating and facilitating the work of the great services whose activities have been already dealt with in a preceding chapter.

How was this central direction to make its action felt 


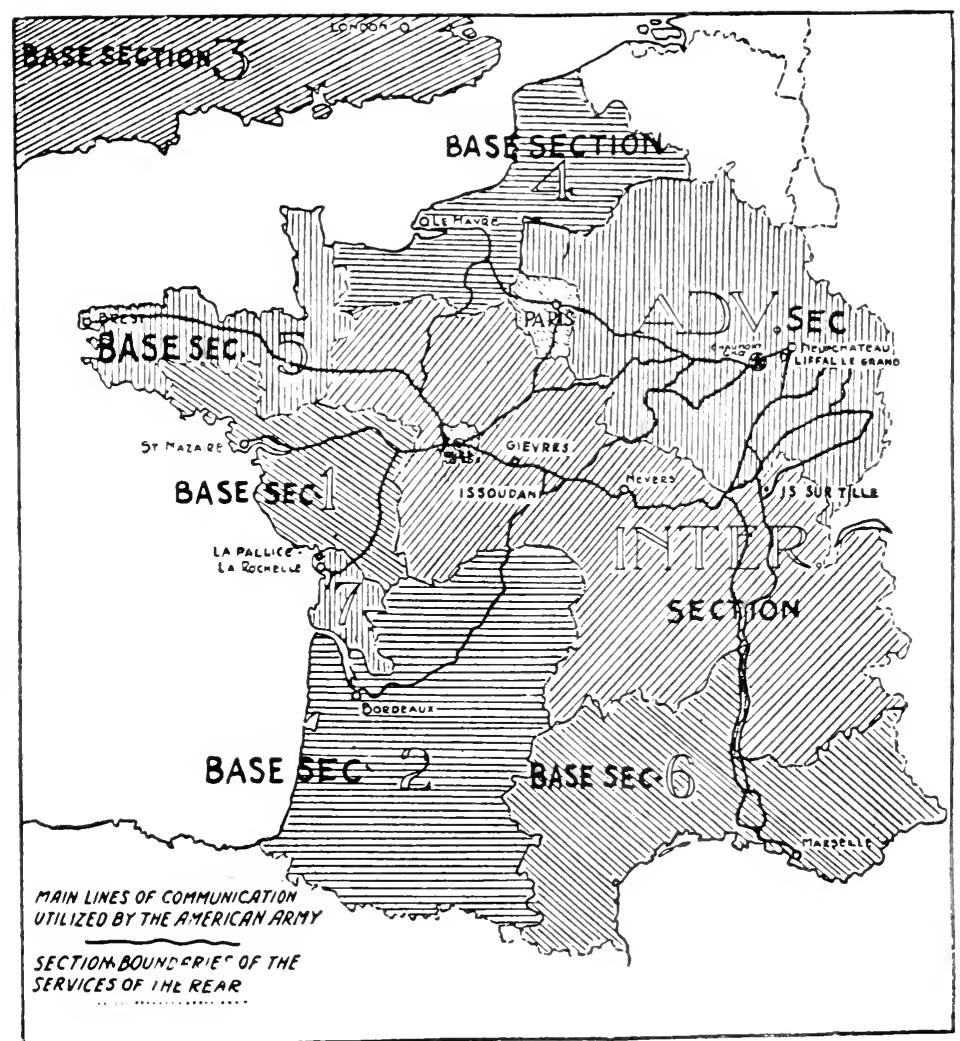

Organization of the Services of the war 

wherever it was necessary? That is to say, at every spot where American troops, American installations, American leave areas were stationed or established?

It must be remembered that after the spring of I9I 8 there were actually more or less important American detachments stationed in the whole of France and in the southeastern part of England.

The key to the difficulty had been sought and found in a territorial organization similar to that existing in the United States in peace time. The S. O. S. headquarters at Tours corresponded to the War Department in Washington. The territory had been divided into sections corresponding to the military departments in the United States.

At the head of each section was placed an officer - a brigadier-general in most cases - who had a double rôle. On the one hand, he controlled all questions of discipline, police, sanitation, of all American troops stationed in his section. On the other hand he was responsible for the technical running of all activities that were established on his territory by services of the A. E. F.

The final organization consisted of :

7 Base Sections,

I Intermediate Section,

I Advance Section.

The limits of these are indicated on the annexed diagram. ${ }^{2}$

The departments of the Seine and of Seine-et-Oise on one hand, the region of Tours, on the other hand, formed two independent districts placed under the immediate con-

2 After the armistice were organized:

Base Section No. 8 (Italy),

Base Section No. 9 (Antwerp and Rotterdam). 


\section{The American Army in the European Conflict}

trol of the general commanding the district of Paris and the Tours headquarters commandant. All the different base sections were, of course, far from possessing the same degree of importance.

Chief of these, according both to date of creation and extent of output, was Base No. I developed in the region of the lower Loire.

When the armistice was signed, twenty-six American ships could simultaneously unload in its ports; fourteen at St. Nazaire, one at Montoir, eight at Nantes, three at Sables d'Olonne. Over thirty-seven per cent. of all materials and supplies imported for the Expeditionary Forces had passed through there: I,600,00o had been unloaded at St. Nazaire, 639,000 at Nantes.

The changes that had occurred at Montoir, the general storage depot for the port of St. Nazaire, were indeed astounding. In I9I 7 , before the work of filling and draining was started, the site of these future installations was nothing but a vast area of flat, marshy ground. Work was actually started in January, I9 I 8; in March, at the time of Secretary Baker's visit, a forest of piles made of reënforced concrete appeared above the surface, ready to support the heavy iron trestles which were to serve for the construction of the warehouses. On the day of the armistice, I 38 of these warehouses were entirely completed, and 125 miles of standard-gauge railway tracks, out of $25^{\circ}$ which were contemplated in the finished project, had already been laid down.

As to the eight berths whose construction had been decided on the Loire, near the mouth of the Brivet, only one was completed at that time.

It is not in the region of the lower Loire that a complete type of a maritime base entirely constructed by the 
Americans is to be found, but rather in the region of the Gironde, the center of Base Section No. 2. There, at the close of hostilities, the port of Bassens and the general storage depot of St. Sulpice were being operated to their full capacity. At Bassens twenty ships could unload at the same time; ten at the French docks and ten at the American, all of which were now entirely completed. Twenty-five per cent. of all the supplies imported for the A. E. F. had been unloaded at Bassens. The American piers built on wooden piles supported two lines of warehouses parallel to the shore. The floor of these warehouses had a weight-carrying capacity of 300 pounds per square foot. One of them attained the immense dimensions of 1,340 feet in length and 100 feet in breadth.

Hardly had a ship docked, than it was taken hold of by companies of stevedores. These companies were organized in as many sections as there were holds in each ship, an arrangement which made it possible to supervise and direct the work. Instantly, all available hoisting machines on board the ship or on the pier came into play, emptying the contents of the holds into the freight cars which were constantly being lined up alongside. No sooner were these loaded than they were forwarded to St. Sulpice over the American tracks which had been laid beside the Bordeaux-Paris main line. If we follow this track we reach not far from St. Sulpice a refrigerating plant with a capacity of 4,000 tons, where American beef scarcely lifted from the vessel's holds underwent a new process of chilling before being continued on its way to Gièvres.

The visit to such an establishment as this may be recommended to the numerous French consumers who have a 


\section{The American Army in the European Conflict}

prejudice against frozen meat as unreasoning as it is detrimental to their pockets.

The American soldier is the heaviest meat consumer in the world. His ration normally of 200 ounces is increased to 240 ounces in winter during field service. According to statistics published in February, I9 I9, by the French Government, the number of existing cattle in France was reduced by the war to I3,314,000 heads. What would have happened had the American Army, instead of being fed upon frozen meat imported from America, been compelled to draw upon the meat resources in France at the rate of over half a kilo per man and per day?

Continuing to follow the American tracks, we arrive at St. Sulpice-Izon, fifteen miles from Bordeaux, at the general storage depot established to absorb the output of the port of Bassens. It is interesting to make a short stop at this place. From the statistical point of view, the installations of St. Sulpice are the most remarkable example of work of such importance completed in such a short time; from the practical point of view, they seem to be destined to play a great part in the economical development of the Bordeaux region.

The St. Sulpice general storage depot was established for the supply of $\mathrm{I}, 000,000$ men during thirty days. The entire project, which was almost finished at the end of hostilities, comprised Io8 warehouses, with a total surface of 2,500,000 square feet, distributed among the following services: air service, chemical warfare, engineers, medical corps, motor transport, ordnance, quartermaster, signal corps.

Besides, 6,000,00o square feet of open storage were provided for and ninety-two miles of standard-gauge 
tracks were laid for the service of this immense depot, where at the close of the war some eight hundred cars were loaded and unloaded each day. The daily shipment toward the zone of the advance and the intermediate section amounted to 55,000 tons.

The speed record in warehouse construction during the course of the war was probably attained at St. Sulpice: In fourteen days six hundred German prisoners, working under the supervision of American engineers, built eighteen warehouses, the majority of which were fifty by five hundred feet.

Troops permanently stationed at St. Sulpice numbered 255 officers and I I, Ooo men. In the neighborhood, at St. Loubès on the Dordogne River, the ordnance had established an immense ammunition depot.

Such were the main installations constructed by the Americans in the Gironde region.

We have dwelt at length on the description of the base sections of St. Nazaire and Bordeaux, because it is there that the most important and varied work was carried out by the Americans. As to all the others we may confine ourselves to the mention of their main characteristics.

Base Section No. 3 which included Great Britain, was especially important on account of the large transit of American troops going to France and also on account of the enormous quantities of material and supplies - a total of 2,485 , Or 9 short tons, that crossed the Channel for the use of the Expeditionary Forces up to May I, I9I9.

Coal figures at the rate of seventy-five per cent. in this total.

In this connection it may be of interest to mention the arrangements made between the French Government and 
the A. E. F. with a view to economizing railroad transportation. According to this agreement, part of the coal imported from Great Britain for the supply of American troops was turned over to the French on its unloading at the Channel ports.

The French Government refunded the same amount of tonnage extracted from the coal fields of central France, located in close proximity to the American lines of communication.

Supplies imported from Great Britain were unloaded in France at the docks operated by the French and British in the ports of Base Section No. 4 (Le Havre); however, at the time of the armistice four berths were permanently assigned to the American Expeditionary Forces in this port.

Brest, headquarters of Base Section No. 5, thanks to the depth and excellence of its harbor became the landing place of huge masses of troops transported during the summer of r9i8. There it was that the Leviathan which draws forty-two feet, disembarked every month effectives which equalled in number those of a German infantry division.

Base Section No. 6, Marseilles, was organized only in June, 19i8. On the one hand it had become essential at that time to take advantage of all existing port facilities on account of the ever-growing importance of debarkation of American supplies. On the other hand the Allies had the submarine menace pretty well under control. When the armistice was signed the Expeditionary Forces were able to unload simultaneously nine ships in the port of Marseilles. The great general storage depot at Miramas, created for the supply of the Salonica Army, 
was partially turned over to the American services of the rear.

It occupied the same comparative position toward Marseilles, as Montoir toward St. Nazaire, or St. Sulpice toward Bassens.

Finally, Base Section No. 7 was established between Base Sections Nos. I and 2 with its center at La Palice and $\mathrm{La}$ Rochelle. It was intended to be equipped at an early date with a port of the same size as that established at Bassens, and the site of which was to be Talmont on the Gironde. 'Its construction was made unnecessary by the signing of the armistice.

While the principal base sections were being developed after the manner above described, the installations in the intermediate zone were proceeding with equal rapidity. Extensive work was being carried on at the great general storage depot at Gièvres which was destined to receive the material for quartermaster, engineers, ordnance, medical department, and chemical warfare services. Although far from completion when the armistice was signed it had already attained dimensions and handled an output of which the following figures may convey some slight idea. Of standard-gauge track 120 miles out of the 240 projected, were in active operation. During October a daily average of I, 600 cars were discharged and loaded. The capacity of the oil and gasoline tanks already in service was $2,000,000$ gallons with a plan for double the quantity. The refrigerator plant could contain 6,500 tons of meat; that is to say, a quantity suffcient for them to have distributed one pound of meat daily to each inhabitant of Paris, London, New York, and Chicago, united. 


\section{The American Army in the European Confict}

Every twenty-four hours sixty carloads of meat arriving from the United States were placed in refrigeration, and an equal number forwarded to the front. The plant was ready for work six months after construction began. Refrigeration was obtained by means of circulatory ammonia pipes which, if put down in line would have reached from New York to Philadelphia. ${ }^{3}$

A number of other American establishments were ranged in the vicinity of the Tours - Bourges - Nevers - Dijon railway line. None, however, were so interesting as that belonging to the salvage service which was situated in the intermediate section at St. Pierre des Corps, near Tours.

A visit to this workshop is one of the most instructive which can be made. Every possible implement and system serving for the repair and recuperation of articles of clothing and equipment, was here to be found. And many things which an outsider would lightly pronounce fit for nothing but the scrap heap were made over "as good as new." Upon their arrival at St. Pierre des Corps all effects were carefully sorted, and subsequently subjected to a series of steaming and sterilizing processes, from which they emerge perfectly cleansed. Drying was effected by the combined action of compressed air and centrifugal force, and each article then repaired according to its category when first sorted out, either mechanically or by hand. A special machine in the space of a few seconds could fit a new heel and sole on a wornout shoe. Waterproofs were mended by hand from

${ }^{3}$ The machines were capable of producing five hundred tons of ice in twenty-four hours, but, as a matter of fact they were not utilized for this purpose, experience having shown that in the moderate climate of France it was not necessary to ice the refrigerator cars used for meat transportation. 
patches cut from others judged completely unfit for service. We have already mentioned in Chapter VI the immense pecuniary saving which the salvage service ${ }^{4}$ assured to the American Government, and in this case we may consider that the money-saving was unimportant in comparison with the economy thus realized on the maritime tonnage.

Naturally the details of organization of the services of the rear are - when they run through the advance section - largely dependent upon the conduct of hostilities. Beside the permanent installations of which we have been speaking, we must also mention others of a more temporary kind. Regulating stations, advanced depots, evacuation hospitals, etc., which the German offensive near Château-Thierry obliged the Americans to install behind that portion of the battle area in which the American divisions were called upon to intervene. And we may say here that if all the difficulties were at length happily surmounted, it is principally to the perfect cooperation between the Franco-American services that credit should be given. This complete accord was assured during the active operations by General Moseley, chief of the Fourth Section at American headquarters on the one side, and by General Payot, director of the French services of the rear on the other.

The permanent installations in the advance section had progressed along the same limes as those of the other intermediate and base sections, and were either completed

${ }^{4}$ In October, 1918, the factory at St. Pierre des Corps employed the following personnel: 26 officers, 745 enlisted men, 730 male civilians, 5,300 women workers, the total being 6,801.

The minimum women's salary was seven francs a day, while a number of those who worked by the piece gained from fifteen to twenty francs daily. 


\section{The American Army in the European Conflict}

or in process of completion well within the specified time limit.

In particular, the advanced depot of Is-sur-Tille, which was to play in the zone of advance the same important rôle as the general storage depot of Gièvres for the intermediate zone section, was about finished. The totality of the projected track system, IIO miles, was in process of exploitation. The bakeries furnished 300 tons of bread daily. Further, toward the front, the regulating station of Liffol-le-Grand was capable of supplying 400,000 men; together with St. Dizier, this station played an important part at the moment of the German retreat. All the establishments of the divers services: Ordnance depots, hospitals, remount stations, and forestry centers were in normal process of development, so that during the formidable offensive in the St. Mihiel salient, and the final operations between the Meuse and the Argonne, the services of supply and of evacuation were running smoothly enough for it to be said that these services of transportation so modestly begun had at length attained the proportions of a colossal organization.

General Atterbury had under his orders at the date of the armistice 2,000 officers and 53,000 men. We have already seen how, upon his arrival in France, he had set about organizing the railroad service of the Expeditionary Forces along the same general lines as those used by one of the great companies in peace time. His program had been perfectly carried out.

It is interesting to mention here that the American railway service possessed a special organization thanks to which they were enabled to trace each car and 
follow its every movement. The system employed may be briefly described as follows:

Each American car bore an individual number, and at the moment of loading in port or warehouse, this number was telegraphed to the central direction together with the numbers of all the cars which formed the same train.

From this moment it was never lost sight of. In each station utilized by the American services were stationed "car checkers" whose duty was to note the numbers of all cars loading, unloading, and sidetracked in the station.

Thus in comparing the lists established on this double information the central direction was always able to ascertain the whereabouts of each particular car, in what station it was to be found, over what lines it had passed, and the length of time that it had been on the road. Any car which was not listed within twenty-four hours was placed upon a tracer bulletin. This method of organization made it possible even during the most difficult periods to make the best of all rolling stock resources. In order to work satisfactorily the system requires a telegraph and telephone organization of the best quality as well as a numerous checking personnel. But the resulting cost is amply compensated by the economies made in material and the time saved in transportation.

As we have already seen the Americans did not construct any important railway line in France; however, as part of the different installations of their rear services, large quantities of rails were laid down in the vicinity of the ports and warehouses which, if spread out in length, would have attained I, 000 miles of standard-gauge track.

Besides the I, I 45 locomotives imported with I 7,000 cars from the United States before the armistice, the railway repair personnel overhauled no less than $I, 423$ loco- 


\section{The American Army in the European Conflict}

motives and 48,00o cars belonging to the French and set in motion upon our canals and waterways more than IOO barges navigating in the American service.

An Order dated December 8, I9 I 7, had organized the automobile service of the Expeditionary Forces. Two subsequent orders dated respectively February I6, and May II, I9I 8 , rendered this service completely independent of the quartermaster's corps, and at the same time defined the precise duties of the service, which was entrusted with the furnishing and upkeep of all automobile vehicles with the exception of those whose type rendered them exclusively appropriate to a definite service, such as, for instance, the artillery tractors which remained under the control of the ordnance, the rolling kitchens, furnished by the quartermaster corps and the motor ambulances belonging to the medical department. The quartermaster, as we have seen in a previous chapter, was also responsible for the furnishing of gasoline, oil, and grease.

On the eleventh of July the " automobile service" changed its name and became the "Motor Transport Corps," General M. L. Walker being placed at its head.

During the entire war and for the same reasons which have already been indicated as limiting the other services, the American Army in France was constantly confronted by the lack of two-thirds of the necessary personnel, and one-half of the vehicles necessary for the Motor Transport. It was not until August, I9 8 , that the tables of organization were definitely drawn up for the Motor Transport Corps.

At this time about $\mathrm{I}, 300,000$ men had already arrived in France and the personnel required by this corps for 
each army was estimated at 45,000 men. The total effectives in personnel then present in Europe amounted to 20,000 men only. At the moment when the troops of the Second Army began to arrive it was found necessary to borrow drivers and mechanics from all the services capable of lending them. As a large part of the American personnel were comparatively without instruction, a school for motor service was established at Decize in July, 1918. At the end of hostilities 700 officers or candidates and 3,000 men had received or were receiving instruction.

The difficulties in regard to material were equally great. It had been decided that for every vehicle sent to France a six months' supply of spare parts should be shipped, after which the system of automatic supply would be practiced. The magnitude of the demands from the allied armies prevented the carrying out of this project, as the troops came too fast for the motor material to keep abreast of their needs.

On April I, I9 18, the total number of vehicles on hand was 37,959 , whereas after calculations made the effectives of the Expeditionary Forces would have required at least I08,000. All that could be found were purchased in Europe with the result that the motor material in use throughout the American Army included 78 different types of passenger cars, 78 kinds of trucks, and 9 kinds of motor-cycles, a fact which was scarcely calculated to simplify repair or the renewal of parts.

The shops of Verneuil ${ }^{5}$ and Romorantin, which pos-

5 Construction of this shop was begun May, 1918, and carried out entirely by the personnel of the Motor Transport Corps and German prisoners. This establishment was not only capable of making all repairs but also of manufacturing the spare parts required by every type of car. By March Ist, 1919, 505,00n pieces had been turned out. 


\section{The American Army in the European Conflict}

sessed a highly perfected equipment, were charged with the repairs - the first of American machines, the second with that of European-made vehicles.

In the zone of the interior, the motor material was not permanently assigned to any particular service, but remained under the control of the central direction which decided where and how it could be utilized to the greatest advantage, and distributed it where most needed. This organization gave excellent practical results, making the very most of the rather slender material on hand.

With troops in the field, the motor transport corps limited its activities to the technical supervision and maintenance of all automobile material. This service had representatives both in divisions and armies.

At the conclusion of hostilities the Expeditionary Forces disposed of : 7,604 passenger cars and of 24,055 trucks, 6,363 had a carrying capacity less than a ton and a half, 3,9 2 a capacity between a ton and a half and two tons, II 503 of three tons, 2,277 of five tons. Consequently by that time the deficit in material was being rapidly made up.

- In order to complete this account of the American services we must now say a word in regard to that one which was perhaps the most important of all and without which the scope of the other services would have been necessarily considerably curtailed. We mean the General Purchasing Board enlarged into the Military Board of Allied Supply.

Had the American Army been obliged to import from the United States all the necessary material for its organization, maintenance, and fighting power, the war 
would probably not be over at the present time of writing.

A few figures will serve to indicate the truth of this assertion. Between June, I9 I 8, and the armistice, as we have seen, some 5,000,000 tons of supplies had been imported from the United States into France. During this same period, the Expeditionary Forces procured through the Purchasing Board I0,000,00o tons on the European markets.

General Pershing, from the moment of his arrival in France, had no illusions as to the questions of tonnage and the inevitable delays which must elapse before a sufficient number of vessels could become available to meet his requirements. According to all estimates and for a long period, the Expeditionary Forces would be compelled to draw on the resources of Europe for a large portion of their supplies.

In the existing organizations, Quartermaster, Engineers, Medical Department, etc., the main services alone disposed of credits and had authority to make purchases. In securing large categories of material destined for general consumption the services would have found themselves competing with one another for their purchase as well as with the other Allies.

It was on this account, and contrary to the advice of a consulting board that General Pershing on August 20th, I 9 I 7 , decided upon the creation of a central board formed by representatives from every service, and presided over by a general purchasing agent, who, without personally disposing of budgetary appropriations, had control and veto power over contracts and bargains made by the other services which only became valid after his approbation. 


\section{The American Army in the European Conflict}

The general purchasing agent was obliged to remain in constant touch with the allied governments, to keep informed as to purchasing facilities in neutral countries, and was also charged with recruiting the labor units employed by the Expeditionary Forces. Colonel Charles G. Dawes ( since promoted general) and one of the best known bankers in the United States, was, from the first, placed at the head of the General Purchasing Board.

The program of Colonel Dawes from the very start was clear and definite, and may be thus summarized: On the one hand to procure for the divers American services, according to the best interests of all, what was necessary for each, suppressing the hard and fast lines heretofore drawn between these various services. On the other hand to centralize and coördinate the purchases among the Allies, so that they would act as associates and no longer as rivals. They could thus procure essentials at a uniform price and distribute them according to the pro rata of individual needs.

On the nineteenth of October, I9I7, General Pershing proposed to create in Paris an Inter-Allied Board for Purchasing, composed of representatives from the United States, Great Britain, and France. He suggested that the three contracting countries should no longer buy in competition with one another but by commissions acting in their name.

The Allies fully entered into the views of the American commander-in-chief and the organization proposed by him was adopted.

On June 20, I9I8, Colonel Dawes was designated to represent the American Army in the Interallied Committee of Supplies.

To-day, now that every one is grateful to the Ameri- 
cans for having contributed in no small measure toward bringing about the unity of command at the front, it should not be forgotten that General Pershing and General Dawes rendered us an almost equal service in giving to the Allies, after the manner that we have just described, what was essential to the common welfare: unity of purchase.

He suggested that, in the future, all purchase of supplies for the three allied armies be made no longer in competition, but in common, by means of a Central-Interallied Purchasing Board. This, however, was only a beginning.

In April, 1918, the experience gained by Colonel Dawes as general purchasing agent of the American Expeditionary Forces had led him to the conclusion that, in the words of a report he addressed to General Pershing:

"Just as there is now a unified military command of the Allies at the front ... there must be a corresponding merging of all separate individual authority of the Allies in reference to the service of supply into one military authority responsible to the corresponding military authority at the front. One is just as necessary as the other."

This principle of a military dictator of the rear of the allied armies - a rear covering France, England, and the United States - in absolute control of all their resources in the supplies, transportation by land and by sea, and facilities of all kinds, involved an economy of labor, money, time - and consequently, of human life the greatness of which can hardly be realized.

It was immediately and completely endorsed by General Pershing.

From that time on, in the course of complicated and strenuous negotiations with the allied authorities, the 


\section{The American Army in the European Conflict}

American High Command constantly tried to enforce that great principle of unity.

A detailed account of these negotiations would, of course, go far beyond the scope of this book. We must, of necessity, limit ourselves to a brief summary of the main results that had been achieved at the time of the armistice.

By the end of May, I9I8, the American, British, and French Governments agreed to the principle of unification of military supplies and utilities for their armies. With this object in view, a board - the Military Board of Allied Supply - was constituted. It consisted of three members ${ }^{6}$ whose decisions regarding the allotment of material and supplies, when unanimously taken had the immediate force of law. The new institution, although it did not possess the character of unity called for by the American suggestion, nevertheless marked a tremendous progress over the situation that had existed so far.

Thanks to the activity, energy, and spirit of coöperation of its members, it constantly gained more and more authority and the scope of its activities kept steadily increasing up to the end of the war.

Among the achievements which, in the future, will earn for the Military Board of Allied Supply the everlasting gratitude of the Allies, let us here mention the pooling of ammunition between the Americans and the French, the creation of a mobile automobile reserve behind the allied armies, the establishment of a system regu-

6 General Payot (president), for the French Army; General Dawes, for the American Army; General Ford, for the British Army (afterwards General Travers Clarke).

Later on, the Belgian and Italian Governments also sent representatives to the Military Board of Allied Supply. They were Major Cumont and General Merrone respectively. 
lating automobile transports, the solution of the very difficult problems concerning the wood and tie situation, and of those concerning the supplies of forage.

The war was brought to its close before the Military Board of Allied Supply had had time to give full measure of the enormous possibilities that were in it. The work it accomplished in the course of its short existence will, nevertheless, in the future be a cause of surprise to the students of the war who will trace to that great, although incomplete, realization of the plans of General Pershing and General Dawes the first successful attempt to carry out, in a practical way, the idea of a Society of Nations.

We have thus rapidly passed in review the organizations of the different American services of the rear in France, and certainly the work as it was carried out was a very great one. But we cannot lay too great a stress upon the fact, that in order to comprehend the real magnitude of the effort furnished by the United States, we should not content ourselves with an examination of what was actually accomplished, but take also into consideration the gigantic work which was being set on foot.

As has already been seen in connection with the shipbuilding question, when the armistice was signed the services of the rear were only just beginning to give the full measure of their capacity, and had war continued we should have seen four miliion of men on our shores in the autumn of I9I9, together with everything which the arrival of such numbers would necessarily entail.

November, I9I 8 , saw, on the contrary all construction work stopped and all contracts annulled, but it still remains interesting to glance for a moment over some of the enterprises in course of realization at this time. 


\section{The American Army in the European Conflict}

In the ports, on a plan of 159 berths, 77 were abandoned. Out of 98,000 cars and 4,00o locomotives about to be delivered, the orders for 68,000 and 2,400 respectively were cancelled. Out of $358,96 \mathrm{I}$ beds ordered for the base hospitals, all but 182,196 were stopped in the course of installation.

During the last thirty days of the war, there had been sent from the United States twice as much material as had arrived during seven whole months of I9I 7 - between June and December.

From the first of June, I9I 8, to the armistice - that is to say, five months and eleven days - the Expeditionary Forces had received from America 2,880,000 tons of supplies against $\mathrm{I}, 530,000$ during the previous year.

But it is useless to add more figures which only prove a foregone conclusion.

What we have already set down is certainly sufficient to demonstrate that in capitulating on November II, I918, Germany did the only possible thing which had been left her to do. 


\section{CHAPTER XII}

CREAT BENEVOLENT ASSOCIATIONS UNDER THE MILITARY AUTHORITY - AMERICAN RED CROSS - YOUNG MEN'S CHRISTIAN ASSOCIATION - KNIGHTS OF COLUMBUS - SALVATION ARMY - AMERICAN LIBRARY ASSOCIATION - JEWISH WELFARE — YOUNG WOMEN'S CHRISTIAN ASSOCIATION, ETC., ETC.

AMERICA is indubitably the country where the greatest use is made of the free right of association.

When a person whose intention it is to found a school, college, hospital, or library, to fight for an idea, or create a fashion, finds that his individual means are inadequate to a large enterprise, an association is formed. And these societies founded in a common interest are powerful in direct proportion to the personal importance and number of their members.

Such societies are often political, others seek success of a material nature, many others are benevolent, moral, or religious in character, for, in this tolerant democracy, charity is as general and frequent as religion is powerful.

The statistics collected at the time of the American Civil War gave an indication of what might be expected from the collective philanthropy of the United States. In I864, individual subscriptions and the sums voted by the municipal or legislative bodies attained the immense figure of $\$ 228,000,000$. The "Sanitary Commission," toward the end of hostilities, disposed of an annual sum exceeding $\$ 8,000,000$, and was formed of 


\section{The American Army in the European Conflict}

more than thirty thousand committees charged with the care and comfort of the soldier at the front.

The "Western Sanitary Commission," founded by General Frémont at the beginning of the Rebellion, was particularly interested in the welfare of the armies who were drawn from the western sections of the country.

The "Christian Commission" looked after the distribution of tracts and pamphlets in the divers camps and the "Commission of War Claims," presided over by General Scott, took charge of claims, even those against the government, by private soldiers.

Such a patriotic and charitable movement at a time when money was scarce gave some idea of what modern America might be expected to accomplish in aid of the combatants of the European war. But the actual effort surpassed all expectations. Those societies, already powerful from their numbers, their wealth, and the position of the directors, at once came to the aid not only of the American combatant, but also of the allied armies.

Unfortunately we shall be able here to give but a short résumé of the extraordinary work accomplished by some of them.

General Pershing at once sought a method by which he might reconcile military prerogatives and centralized authority with the autonomy and spirit of initiative of each individual society. We may consider that his actions were well inspired since, under his authority, the charitable organizations placed under military control grew, developed, and extended the sphere of their utility always for the greater good and comfort of the combatant and without the slightest encroachment upon army discipline. This centralization of authority usefully coördi- 
nated these separate activities and prevented the waste which would have resulted if several different societies had worked on precisely the same lines.

Many of the associations recognized by the Federal Government already existed before the beginning of hostilities. Upon the declaration of war, they were militarized and placed under the direct authority of the Secretary of War and afterward under that of the commander-in-chief. General Pershing, in his turn, had to decide as to the particular range of each society in France and placed these philanthropic organizations under the immediate control of the first section of the General Staff.

Thus we read in General Order No. 26 that the American Red Cross Society would be particularly entrusted with the care of sick and wounded, while the Y. M. C. A. would work more especially for the moralization, recreation, instruction, and amusement of the contingents.

The supervision exercised over all the philanthropic societies by the high command was constant; every month an officer from headquarters assembled the delegates of each association in Paris, studied their reports, listened to their suggestions or to their complaints.

In each army, likewise, and sometimes in each corps, a staff officer was particularly accredited to the surveillance of the organization operating with his unit.

Certain societies such as the Red Cross, Y. M. C. A., Knights of Columbus, Salvation Army kept their own complete autonomy, and were under the direct control of the high command. Others less powerful, or whose work was less specialized, like the Library Association, the Jewish Welfare, or Young Women's Christian Association were affiliated with the Y. M. C. A. 


\section{The American Army in the European Conflict}

Let us rapidly examine the work of each.

On the twelfth of July, I9I7, twelve delegates of the American Red Cross arrived in France at the same date with General Pershing. The day the armistice was signed, more than six thousand employees of the society assigned only to the French service were devoting themselves to the care of the wounded in hospitals or to that of children and refugees.

The first duty of the Red Cross was to aid and to ameliorate the condition not only of the soldier but likewise of his family and other war victims.

The American Army was not yet disembarked, when in order to respond to the desire manifested by 20,000,000 Americans and subscribers who by their generosity had raised $\$ 100,000,000$, the delegates of the Red Cross came to Europe to get in close touch with the Allies.

They began by augmenting the number of French canteens. Many women offered their services, so that in the lapse of a few months these establishments were able to distribute food and hot drinks to 250,000 soldiers a week.

The sum of $\$ 3,000$, 000 was distributed in aid of the families of French soldiers who were in need and who were recommended by our high command.

Thirty dispensaries or children's hospitals were opened. At Evian the French civilians repatriated through Germany found American counters hospitably and liberally provisioned.

Five thousand homeless persons were lodged in Paris thanks to the work of the Red Cross and other French societies who terminated the construction of unfinished buildings. 
From March to June, I9I7, 620,000 persons were cared for by this organization. ${ }^{1}$

When the Expeditionary Forces reached France, its services attained a far greater extension; but this growth was accomplished without detriment to anything already being done for our own soldiers or civil population.

It became, however, necessary to multiply the number of canteens, and thirty more were constructed capable of furnishing nourishment for from six to eight thousand men per day.

More delegates were appointed in each important unit whose mission was to oversee and arrange for the arrival of all sorts of material in the hospitals and ambulances at the front. Each division had an officer called "searcher" whose object was to get in touch with such soldiers as were seeking means of communicating with their family, to look after his private interests at home, or who was simply in need of moral "cheering up."

The Red Cross succeeded also in establishing movable canteens at the front in order to provide the men who could not be reached by regular food supplies with hot drinks.

But the most useful, if not the most brilliant, aim of this organization was to install hospitals and to furnish medical necessities to the sanitary formations of the army.

Improvised hospitals were opened at Beauvais, Jouy, and Juilly which rendered great services during the battles of the spring and summer of rgis. At the same time, the sanitary formations of the Red Cross of the Paris

1 Marshall Pétain officially expressed his appreciation of the immense service of the American Red Cross. 


\section{The American Army in the European Conflict}

region were increased. Toward the end of September, the number of beds available in the capital and its surroundings was over 7,000 .

During the month which preceded the armistice, the Red Cross provided beds, medical care, and food to an average of 300,000 men a day.

All the bandages of the army and a portion of the splints came from the Red Cross stores. This organization supplied at the same time 4,0oo French hospitals with medical necessities and surgical appliances.

The bandages were issued by the workrooms at the rate of 200,000 a week. This number was doubled by the shipments coming from the United States.

Special diet kitchens for the sick were installed and directed by the same organization in French and American hospitals.

There were about 20,000 trained nurses; those speaking French were detached for service in our hospitals.

A special department was organized for the care of the mutilated. This section combined to supply our Sanitary Commission with one hundred and fifty artificial limbs a month.

Four hundred men and women were employed in hospitals and dressing stations, to write advising the families in America as to the circumstances in which their soldier relatives had been killed or wounded, supplying any available information on those who were missing. In the latter half of the year igis, the special information (home communication and searchers) department wrote or received on an average of 13,500 letters a month. The same department organized more than eighty barracks in the neighborhood of the hospitals in order to take care of convalescents. 
The Welfare and Recreation bureaus distributed pamphlets, ${ }^{2}$ books, magazines, and newspapers by the hundred thousand, as well as games of all sorts. In many of the hospitals and camps, it founded officers' or nurses' clubs.

The Scientific Section of the Red Cross organized a service of medical and surgical information and published a monthly review which was widely distributed. It organized a department for research as to the best means of fighting vermin, curing trench fever, wounds to the lungs, and poison gas. To this list, already so extensive, of practical work efficiently accomplished, we must add the liberal distribution of clothing, of knitted garments, sweaters, shoes, trench boots and socks, sent to the French as well as to American soldiers.

This great organization rendered services to which it is difficult here to do justice, as they go b.eyond the limits of our present sketch. The following sums may give some idea of the work accomplished by the American Red Cross. At the time of the armistice, the amount of money subscribed and which the organization held at its disposal was $\$ 300,000,000$. To this sum should be added the bandages, and surgical dressings, clothes, and materials of all sorts of which the value to-day is $\$ 80,000,000$.

The success which the American Red Cross achieved on the field of charity was not alone due to the extent of its wealth, but also to the enlightenment with which its chiefs administered and distributed that wealth. By the use of direct method and the suppression of red tape, the directors succeeded in reaching without delay their allies as well as their own compatriots. They invariably

2 See later on the American Library Association. 


\section{The American Army in the European Conflict}

showed in difficult and unforeseen circumstances prompt decision and instantaneous grasp of the situation.

Among those to whom France and the United States owe so much, four stand out whose names will always be remembered in connection with the work of this beneficent organization. In the United States, Ex-President Taft, head of the Red Cross, who by his eloquent appeals elicited such a generous response from individuals as well as from the certain collectivities. This gigantic accumulation made it possible to achieve the great things which were accomplished. In France, Mr. P. Davison, president of the war committee for Europe, Colonel Gibson, commissioner for France, and $\mathrm{Mr}$. James H. Perkins directed the work in all its ramifications.

The Young Men's Christian Association, known to all Americans and now to most of the French, existed long before the war, which had scarcely been declared before the Y. M. C. A., on the twentieth of April, offered its services to the President.

This organization set to work without losing any time. While it was establishing its canteens and its recreation halls in the first American camps where recruits were gathered, it sent Messrs. Carter and Davis to Paris, where the European seat of the association began its labors. In Order No. 26, General Pershing indicated to the Y. M. C. A. that its object should be the social, physical, and religious perfecting of the soldier. By Order No. 33 of the sixth of September, I9 7 , the commanderin-chief of the Expeditionary Forces advised his officers and men to make use of the advantages offered by the association. He added: 


$$
\text { Y. M. C. A. }
$$

"The canteens of the Y. M. C. A. will be organized like military canteens, of which they are to take the place. In that way, officers and soldiers will not be distracted from their military service.

"Consequently in future, officers will forbid the opening of military canteens in the places where the Y. M. C. A. has already established a canteen.

"The canteens will not only be operated in the areas which are removed from active operations; on the contrary, it is desirable to have them as near the front as the military situation will permit so that the soldiers can have the comfort which these establishments offer at a time when they are likely to be most in need of them."

The Y. M. C. A. took pains to carry out the wishes of the commander-in-chief. Wherever there was an agglomeration of American soldiers, a canteen was installed. As a result, the organization operated as many as 1,252 canteens or recreation halls.

In the Y. M. C. A. huts, the men could purchase certain kinds of food - chocolate, toilet articles, etc. - and procure, free of charge, writing paper, newspapers, and books. These installations rendered good service, and General Pershing was able to write to Mr. Carter at the end of the war that:

"The society had given valuable assistance to the Expeditionary Forces by the working of their canteens. Handicapped by the shortage of transport by sea and land, the Y. M. C. A. had accomplished more than could have been expected, and you may be sure that the association has had a large part in the great work accomplished by the American Army."

The Association endeavored to keep always in view the moral and religious work which it proposed to achieve. It got in touch with the chaplains of all the different denominations and placed halls at their disposal for the exercise of religious services. 


\section{The American Army in the European Conflict}

In their reading rooms were to be found besides books furnished by the Library Association and the millions of newspapers distributed by the Y. M. C. A., pamphlets and booklets edited by the Association itself; the section for the distribution of the writings of a moral nature alone sent out 600,000 publications a week. Another section specialized the study of the Bible which it undertook to spread and interpret.

The Association was bent on entertaining the soldiers and keeping them from being homesick. It secured the assistance of 427 professional actors and actresses and gave, in the neighborhood of its centers, 3,000 performances. It provided 825 costumes a month to enable the officers and men to organize theatricals at the front. In the month of January, I9I 8 , it distributed I, I 8 instruments and 20,000 pieces of music.

The moving picture section gave, on an average, 2,400 representations a week in France and later on in the enemy zone occupied by the Americans. They often organized free performances for the children in our villages.

The department for athletic sports was very active. It encouraged more particularly baseball, basketball, tennis, boxing, football, and races of all sorts. The competition games organized by the Y. M. C. A. during the last six months of I9I 8 brought together 4,770,000 players and 9,000,000 spectators. In Paris, the Association gave exhibitions of boxing or other athletic games at the Palais de Glace and in the Circus to which men in uniform were admitted free.

Several of the teachers of the sports department became monitors in the regular army and prepared the men for the June international games where the competitors belonged to twenty-one allied and associated countries. 


$$
\text { Y. M. C. A. }
$$

The Educational Section opened courses for the illiterate, courses in French, and courses for higher education, even for studies of law and architecture.

More recently, the Y. M. C. A. has largely contributed toward the founding of the university of the American Army at Beaune, destined to accommodate 20,000 scholars.

The Association also opened in France seventy-five hotels, restaurants, or cafés. It organized recreation halls in the leave areas for American officers and men: Aix-les-Bains, Chambéry, Challes-les-aux, Chamonix, St. Gervais, in Haute-Savoie; Nimes in the department of Gard, Grenoble, Uriage-les-Bains, Allevard-les-Bains in the Dauphiné, Nice, Cannes, Menton, Monte Carlo on the Riviera, Valse-les-Bains in the Ardèche; Lamalou-lesBains in the Hérault, La Bourboule, le Mont-Dore in Auvergne; Cauterets, Eaux-Bonnes, Bagnères-de-Luchon in the Pyrénées, St. Malo, Dinard, and Paramé in Brittany.

The organization also undertook to facilitate communications between the soldier and his family, following which purpose it distributed I 80,000,000 sheets of writing paper and sent to the United States more than $\$ 16,000,000$ transmitted by the officers and men to their relations in America.

As a matter of principle, the Y. M. C. A. made it a habit to sell articles in its canteens at a moderate price, without, however, looking for profit; it has also shown that it knows how to give. We find in its budget, under the head of "Donations," sums aggregating more than $\$ 1,000,000$. The Christmas presents alone amounted to more than $\$ 500,000 .^{3}$

${ }^{3} \$ 200,000,000$ were sent to the Y. M. C. A. from America. 


\section{The American Army in the European Conflict}

The organization on January Ioth, I919, had 586 active members, sixty-eight of whom have been decorated and cited for their courage by the commanders-in-chief of the allied armies. The Association operated I,4 I 4 establishments besides canteens, depots, garages, theaters, and gymnasiums.

The Y. M. C. A. collaborated in the work of the "Foyer du Soldat," and the two societies combined founded I, 452 foyers.

It also centralized the work of the American Library Association, the Jewish Welfare, and the Young Women's Christian Association, acting as their intermediary with the commander-in-chief of the Expeditionary Forces.

The scope of this work was extensive and grew in proportion as the army developed. It was impossible to visit a cantonment, a camp, or a village, however near to the front they might be, without finding on a house, often in ruins, on a tent or a barrack, the symbolical triangle of the Association. ${ }^{4}$

The association of the Knights of Columbus was founded in the United States about twenty years ago. It started with 65,000 members; now it has more than 500,000 .

In the beginning, this organization, composed entirely of Catholics, assisted American soldiers during the war against Mexico. At that time, no private contribution with a view to increasing its resources had been raised, and, without any special appeal to the generosity of its members, the society of the Knights of Columbus had succeeded in making large distribution of food, of equip-

4 The triangle represents, by its three points, the body, the mind, and the spirit. 


$$
\text { K. of } C \text {. }
$$

ment, and of games to the combatants. When America entered into the European conflict, the Knights offered their services to the President of the United States; they were accepted. The capital at their disposal not being sufficient to carry out in America and in France the liberal program which the society had in view, the Knights of Columbus raised generous subscriptions amounting during the war to more than $\$$ I $5,000,000$.

The society opened in the United States 150 recreation halls and canteens where the soldier could find games, writing paper, newspapers, books, musical instruments, and also facilities for the practice of the Catholic religion. In Europe, the Knights of Columbus were represented by 765 delegates. They shipped several thousand tons of merchandise. One hundred and twenty-five barracks were erected, where writing paper, pens and ink, chocolate, candy, tobacco, soap, towels, paper, and hot drinks were given out free of charge. ${ }^{5}$

The Knights of Columbus, like the Red Cross, sent their rolling kitchens - of which fifteen were in operation at the end of hostilities - into the front-line trenches in order to distribute hot soup to the soldiers.

This society made a great effort to develop a taste for athletic games. Its budget shows a large provision for the acquirement of the accessories necessary to the sports most favored by the American soldiers. Great success was achieved in the organization of all sorts of shows, and in theatricals a band of minstrels gave frequent and extremely popular performances.

5 General headquarters were in favor of gratuitous distribution in the trenches or when the soldiers could not procure regular rations. On the other hand it was considered that the troops ought to pay for the above articles when they were withdrawn from the front or scattered in the rest areas. The American soldier's pay was more than one dollar a day. 


\section{The American Army in the European Conflict}

Under the vigorous impulsion of Supreme Knight Edward L. Hearn, the Knights of Columbus contributed largely to the well-being of the American trooper and succeeded in gaining his confidence and esteem entirely regardless of religious opinions.

The Salvation Army, which began work in July, I9 I 7 , differed mainly from the other benevolent organizations in having specialized its work near and at the front. No canteens were established by this society in the large towns or at the rear, but canteens were opened for the fighting units at the earliest possible moment; thus, before the First Division had completed its installation in the neighborhood of Gondrécourt, the Salvation Army had already opened its recreation halls and reading rooms for the men. When the troops moved into line the workers who had been with them during periods of rest or instruction followed them to points close to the firing line where canteens were set up and hot coffee and chocolate distributed freely to those who were leaving the trenches or going under fire, hot doughnuts were also cooked and sent into the trenches.

When an offensive was in progress the Salvation Army women assisted in the advance dressing stations, and when the American front was extended to the Montdidier and Soissons sector, canteens were operated in dugouts which were alone available.

This society was directed by Colonel Baker and comprised about two hundred men and women and about three hundred French or American workers, most of whom were frequently under shell-fire, and as may readily be imagined the delegates of the Salvation Army were extremely popular with the fighting troops. 


\section{A. L. A.}

The American Library Association began its regular work in January, I9I8.

At this time a dispatch office was established at Hoboken for the purpose of assembling books and placing them on the transports. The books sent in this way were unloaded in France and placed at the disposal of the men either in the Y. M. C. A. huts or directly with the men themselves.

At the same time, the American Library Association dispatched a representative to France to lay the foundation of a broader service.

The delegate easily convinced the commander-in-chief of the utility of his mission, and General Pershing took pains to request the Secretary of War that fifty tons a month might be reserved on the military transports for the carriage of the books and pamphlets for the American Army.

By common agreement, it was decided that the Library Association should furnish books to the American Red Cross, the Y. M. C. A., and the Knights of Columbus. These societies on their part agreed to see that the soldiers received the books entrusted to their care.

In the month of April, the Association inaugurated its present headquarters at Paris and its central library at ro Rue de l'Elysée.

In September, the Postmaster General in Washington agreed to forward free all publications sent to Europe by this society, and general headquarters authorized its representatives to communicate directly with the military authorities of the Expeditionary Forces.

From that time on, the Library Association developed rapidly and extensively.

Shipping bureaus were installed at Newport News. 


\section{The American Army in the European Conflict}

Boston, Philadelphia, and New York. They succeeded in shipping upward of 100,000 volumes a month.

By February I, I9 19, I, 800,000 books had been sent to France. A lot of libraries were opened in Y. M. C. A., Knights of Columbus, Salvation Army, Y. W. C. A., and Jewish Welfare organizations and 264 in detached camps belonging to the Expeditionary Forces.

Each American ambulance was endowed with a collection of books.

A similar service was organized in England and in Russia for.the benefit of the troops stationed and fighting in these countries.

The Paris shipping office sent out 4,347 specified volumes to certain soldiers who had requested them.

The library in Paris was much frequented by officers and men stationed there, or passing through the capital. It was utilized by 30,000 members of the Expeditionary Forces.

After the armistice was signed, the number of books asked for by all the branch offices was greatly increased. The soldiers wished particularly to have instructive books, text-books, works of elementary education used in primary and in high schools. More than half a million books of this sort were recently issued; most of these volumes were taken by officer-instructors in the military schools.

A delegate of the Library Association, to be found in every army, brought to the notice of the central committee any criticism which he might think necessary, on the operation of the work in the unit to which he was attached.

Libraries were also opened at Châtillon, Chaumont, Dijon, Gondrécourt, Neufchâteau, Nevers, Tours, and in the hospital centers of Allerey, Le Mans, Mesves, Save- 
nay. A reading room was later installed at Coblenz, another opened at Trèves. Sixty-two army transports were supplied with a library.

The society largely contributed to the supply of works on technical and specialized subjects, which could be consulted either at the second section of general headquarters at Chaumont or at the staff school at Langres.

Representing the Congressional Library at Washington, it also furnished the necessary documents for the labor of the Peace Conference.

Latterly, it has collaborated with the "Association des Bibliothécaires Français" and the sub-committee of the "Renaissance des Cités" with the idea of making American Library methods better known in France, also to facilitate the future establishment of libraries in the devastated regions.

The Jewish Welfare Board did not begin work in France until the last months of the war.

The Association desired to ensure the exercise of the Jewish rites in the American Army, to distribute certain kinds of literature, and to render personal service to the Jewish soldier, more especially to locate his relatives in Russia or Poland.

Fourteen central offices were installed at Bordeaux, Brest, Coblenz, Dijon, Gièvres, Le Mans, Nantes, Paris, St. Aignan, St. Nazaire, Tours, Pontanézen, Kerhuon, and in the principal camps where the soldiers gathered before their embarkation for the United States. In these centers, the rabbis exercised the rites of the Jewish church, preferably on Friday night. I I,000 abbreviated Jewish prayers, 7,000 books on Jewish thought, and 5,000 extracts from the Scriptures were distributed. 


\section{The American Army in the European Conflict}

The soldiers were also supplied in the canteens with tea, chocolate, bread, preserves, cakes, cigarettes, and writing paper.

At the request of certain French and English organizations and also in answer to the call of the Y. M. C. A., the Young Women's Christian Association decided to carry on in Europe the charitable work which had been largely organized among the munition workers in the United States.

The object of its members was to give help to the women of all nationalities working for the armies. Thus, wherever women were employed, especially in the services of the chief signal officer, the Association established lodgings or "Hostess Houses." It was thus represented at Brest, St. Nazaire, Bordeaux, Le Havre, Tours, Paris, Nevers, Langres, Chaumont, Neufchâteau, Toul where telephone centrals had been installed, and even at Souilly during the battle between the Meuse and the Argonne when the First Army general headquarters was operating in this locality.

The Y. W. C. A. opened clubs for women in the neighborhood of base hospitals in order to provide rest and recreation halls for the nurses. Clubs were organized in Paris, Savenay, Brest, St. Nazaire, Coetquidan, Nantes, Angers, Tours, Joinville, Chatel-Guyon, Vichy, Mars, Allerey, Dijon, Chaumont Contrexéville, Vittel, and Bazoilles.

The association installed and operated three hotels in Paris where women employed in war work found board and lodging at low rates. Other hotels of the same order were opened at Brest, Bordeaux, Le Havre, Le Mans, Tours, Toul, Chaumont, and Coblenz. 
Canteens, where French women working either for the American services or in our own factories were admitted, were organized: Five in Paris; three in Lyons; three at Bourges; two at Roanne; one at Tours, St. Etienne, Romorantin, Montluçon, and Is-sur-Tille.

At Lyons, to mention the work done by this association in only one of these cities, 6,000 women made use of the canteens of this organization, which in this one center succeeded in serving I, 200 meals a day.

M. Loucheur, in recognition of the devoted work of this society, asked the Y. W. C. A. not to close its canteens at the end of the war. This organization continued accordingly after the armistice under Franco-American direction.

While some American organizations, such as the Red Cross, did not hesitate before the landing of the Amerian troops and even after their arrival to offer their services and to assist our combatants, there was another category which did not wait until the United States declared war to manifest their interest in our cause with equal devotion and enlightenment.

A few weeks after the opening of hostilities, the American colony in Paris organized the ambulance of Neuilly. ${ }^{6}$ This hospital center soon disposed of about a thousand beds. The sick and wounded were cared for at Neuilly by a personnel of nurses and doctors as devoted as they were capable, and the admirable service given there was soon effectively supplemented by the generous gift of a

6 When the commander-in-chief decided to militarize the various organizations which were placed at the service of the army, general orders, dated July 2oth, converted the Neuilly Ambulance into Base Hospital No. $x$. 


\section{The American Army in the European Conflict}

sanitary train for the direct evacuation of the wounded. Colonel Robert Bacon, former ambassador to Paris, whose zeal in our cause was as much appreciated in his lifetime as his death is now regretted, placed this train at the disposal of the French command. It remained throughout the war the best equipped and the most comfortable of its kind in service.

Nor were the large funds of which the Neuilly ambulance disposed utilized only for the running of the hospital or of the train. A distributing committee, presided over by Mrs. Robert Woods Bliss, was formed with the object of collecting American gifts and subscriptions for the soldier at the front.

A service of field ambulances was also subscribed for by funds largely sent from the United States. It consisted of twenty-five sections of motor ambulances for the transportation of wounded and operated by volunteers enrolled under the direction of Mr. Piatt H. Andrew, whose zeal and devotion were appreciated in all the French divisions.

The Norton-Harjes ambulance service, due also to American generosity and which comprised fifteen sections, was also placed at the disposal of the French command.

Many American women, responding to the call of the "American Fund for French Wounded," 7 grouped themselves together to help our combatants.

7 The first appeal for the French wounded was made in England by Mrs. Floyd. Later the society assumed a purely American character.

At the head of this formation was Mrs. Lathrop, who worked indefatigably up to the end of the war. Six hundred committees were formed in the United States and gifts to the value of $\$ 5,000,000$ were sent to France, permitting the establishment of depots and dispensaries in thirty French towns.

Among the women who directed the efforts in the aid of the French wounded we ought to mention Mrs. Francis Shaw, Mrs. William Gwin, 
The American Surgical Dressings Association, founded in Paris by Mrs. Austin, had also many working committees in America. Thanks to this work our hospitals rarely lacked dressings or bandages for the wounded.

The Fatherless Children of France, working in close touch with the French Government, through the care and adoption of war orphans has accomplished a work too well known in America and too extensive to be here fully described.

The same may be said of the work of Miss Anne Morgan, particularly in the devastated regions, which has been constant and devoted from the first.

Probably the American woman whose work covered the broadest field was Mrs. Wharton. Her ouvroir or workroom gave employment to quantities of girls thrown out of work by the war.

The American Hostels for Refugees, into which was merged the "Foyer Franco-Belge," was created under the presidency of Mrs. Wharton during the early days of October, I9I4. Six separate committees worked to aid the refugees of the invaded districts; an infirmary was established, a depot for the gratuitous distribution of supplies opened, an employment bureau established, a restaurant, dispensary, and a workroom, still running in I9I9, were installed down town, as well as a center for the free distribution of clothing.

Later under the increasing stress of the German offenand Miss Anna M. Vail, all working in Paris; Mrs. Charles Chapin and Mrs. Ethelbert Nevin in New York; Miss Edith Bangs in Boston and Mrs. Russell Tyson in Chicago. Thanks to the enterprise and devotion of these ladies and their collaborators, $4 \mathrm{r}, 812$ cases were received from America, and 44,794 were distributed to hospitals and among the needy families of soldiers. The committee unwilling to cease their good works with the cessation of hostilities plan to endow a permanent children's hospital of one hundred beds in Rheims. 
sive of I9I8, several apartment houses were opened and free lodging given to refugees.

For one year, the society worked in collaboration with the Red Cross, but once more obtained full autonomy in August, I9I 8.

The work of the Children of Flanders, with a large colony of refugee children, was established in five different centers in France, and a group of workrooms for the supply of garments and knitted goods.

The American Convalescent Homes established three principal homes in France for the families and children of refugees either suffering from or threatened by tuberculosis.

French Tuberculosis War Victims was founded in $19 \mathrm{I} 6$ with a view to the care and cure of light cases of tuberculosis through obtaining the best conditions of fresh air and hygiene for the patients. Over $\$ 700,000$ were raised in America for this enterprise, which was subsequently taken over by the Red Cross.

During the summer of I9I4, Mr. Herrick, American ambassador in Paris, seeing the number of charitable organizations that were being formed in France and with a view of coördinating the individual efforts which were being made by an arrangement with the French Government and high command, established the:

American Relief Clearing House with Mr. Harjes as president and Mr. H. O. Beatty as director. This organization remained in touch with our front and rear services, obtained free transportation on the principal lines of navigation and railways, thus distributing gratis the quantities of gifts of all sorts which were due to American generosity. 
From November, I9I4, to June, I9I7, the clearing house handled I 50,000 cases of clothing and supplies, distributed over $\$ 2,000,000$ in cash, and $\$ 1,000,000$ worth of supplies.

When America entered the war, the Relief Clearing House passed over its work to the American Red Cross.

Naturally the great benevolent organizations deserve a more complete study than our insufficient experience of their varied activities has permitted us to record here. It is to be hoped not only that they may one day be more worthily described, but also that we may investigate in France the causes which have brought about such colossal results as have been achieved by the American method of association.

Almost all these societies have, in a great measure, ameliorated the material welfare of our combatants, but this perhaps is one of the least important parts of the work accomplished. In attenuating the sufferings of the victims of war, they have succeeded in maintaining a high morale near the front, and have accomplished the great result of shortening the distance which separates the soldier from his home.

It would be difficult to describe adequately the manifold activities undertaken by the American residents and even of the transient visitors in Paris when the war broke out and which were developed by private or collective initiative as it continued. To do so would require a volume and not merely a chapter. We must therefore beg our readers to consider that none have been voluntarily omitted in this brief sketch, but that those of which we speak from certain personal knowledge may be taken as a type of the many others, equally meritorious. which 
384 The American Army in the European Conflict

the authors of this book have not had the chance of knowing individually.

Thanks to all of them, and thanks to the great variety and scope of their benevolent activities, the man no longer of fighting age who was obliged to remain in the United States, and the woman whom family duties kept at home, were both able to take a useful share in the European war according to their means but more especially in direct proportion to their personal influence and energy. 


\section{CHAPTER XIII}

FRANCO-AMERICAN COÖPERATION - CONCLUSION

DuRING the two years that the American forces were establishing their services and fighting upon French soil, they were necessarily brought into close and constant relations with our military administration and with the civil population of our country.

In order to procure supplies and material of all sorts - lodgings, transport, and so forth - they were obliged to apply to the competent French authorities, and, when actively engaged, they were in permanent touch with the French military command.

A complete association of the French and American services, both in the interior and in the army zones, became an essential element of future success.

During their first interview upon these subjects, General Pershing and the Minister of War, M. Painlevé, found themselves in complete agreement as to the necessity of hastening the entry into line of the American contingents; and, in order to facilitate this in every way, they at once decided to organize a permanent liaison system.

The Americans proceeded to appoint a certain number of missions or individual officers to act as liaison agents with the particular allied staffs called upon to work in conjunction with their own. According to the importance of the questions involved, these American representatives were empowered either to reach a direct settlement or report the affair to their superiors.

Officers representing the high command of the Ex385 
peditionary Forces were to be found in all the offices of our French general headquarters, of our War Ministry, of our regional staffs and railway regulating stations where American interests were involved, as well as at the headquarters of the interallied commander-in-chief. ${ }^{1}$

In order to facilitate the work of the Americans, we on our side increased our liaison services and even when it seemed advisable, modified the interior organization of some of our departments, so that our new ally would find his task simplified.

A's soon as the American headquarters were permanently constituted at Chaumont, the French commanderin-chief appointed a military mission, composed of analogous corresponding services, which was particularly entrusted with the duty of furnishing interpreters and liaison agents ${ }^{2}$ to the recently arrived American units.

In the interior, wherever important American services were to be found, as in the base ports and regional staffs, the Minister of War created missions which were to serve as intermediaries between our allies and the civil and military administration. In the principal staffs and important services of our ministry, bureaus were installed to supervise and coördinate all questions involving American coöperation.

1 The heads of these American military missions were:

At the headquarters of the Allied Armies: Colonel T. Bentley Mott, at present military attaché in Paris.

At the headquarters of the French Armies: Colonel Frank Parker, succeeded by Colonel C. de Witt Wilcox, subsequently by Colonel Paul H. Clark.

At the headquarters of the British Armies: Colonel Robert Bacon.

Colonel Herman Harjes was entrusted with the organization and inspection of the personnel of all the liaison missions attached to the various staffs and services.

2 This French mission was at first under the orders of General Ragueneau, subsequently under those of Colonel Linard. 
On December 19, 1917, the Prime Minister appointed a special Councillor on Franco-American Affairs to the under Secretary of $\mathrm{War}^{3}$ and also created a central office of Franco-American Relations.

On June I9th, I9I8, the General Commission for Franco-American War Affairs ${ }^{4}$ was organized. Its chief, to whom was entrusted the duty of coördinating the work of the Franco-American bureaus in the ministries, was also to follow up the execution of the different measures which had been judged necessary. At the same time the High Commissioner directed the work which was undertaken in America through a delegate who was to take charge of the services already created in the United States by the French Republic.

In general such were the measures taken in France to facilitate the entry into line of the American contingents.

It is not for us to estimate the value of this assistance. We may, with greater relevance, reproduce here one of the passages from General Pershing's telegraphic report to the War Department in Washington summing up, after the armistice, the operations in which his armies had taken part:

"The French Government and Army have always stood ready to furnish us with supplies, equipment, and transportation and to aid us in every way. In the towns and hamlets wherever our troops have been stationed or billeted, the French people have everywhere received them more as relatives and intimate friends than as soldiers of a foreign army.

"For these things words are quite inadequate to express our gratitude."

${ }^{3}$ M. Jules Cambon, formerly French Ambassador to Washington and to Berlin.

4 Under the direction of M. André Tardieu. 
The armistice found General Pershing at the head of an army more than two million strong. In the course of 1919 this force would have been doubled. Both in France and America every provision was made to attain this result; the powerful mechanism which had been set on foot in view of mobilization was running without a hitch. Transports and reception camps in Europe were kept up to their full capacity. Nothing, not even the German submarine, was now able to seriously impede the regular movement of reënforcement.

Undoubtedly the knowledge of this situation had its influence on the enemies' decision to abandon the struggle, so that America would not pursue her effort to a finish even more disastrous to Germany.

The two million soldiers already in Europe sufficed to determine our victory. Thanks to American aid, the enemy had been forced: first to stabilize, then to defensive warfare followed by a more and more precipitate retreat and, finally, on the eleventh of November, to a capitulation.

No sooner had the armistice been signed than the commander-in-chief, while watching the advance of his troops toward the Rhine, had his mind preoccupied by another thought, that of lightening war-worn France of an occupation which had now become unnecessary. From that moment, the Americans turned homeward with the same order and the same rapidity which had characterized their arrival on our shores.

Of their passage among us, of their exploits on our battlefields, are they to leave no more than a memory? We hope otherwise.

The contact of our populations with these Americans, energetic in action, of open minds and rapid initiative, 
has surely enlarged their horizon. Our industrial, commercial and agricultural methods, possibly our social and political conceptions, may be modified by interchange of thought with men constantly seeking movement and progress. We may perhaps find that the natural tendency toward routine and bureaucracy with which we are often reproached will be gradually modified by the penetration of new ideas.

The love of open air and outdoor sports so characteristic of American youth cannot but have been an excellent example.

Our technicists, brought in touch with the American method of work, will surely have made many useful observations concerning, for instance, the scientific and at the same time simple working of railroads, telephones, and telegraphs.

Let us recall that, upon leaving France, the American services have turned over to us various working facilities - ports, docks, warehouses, shops, rolling stock, and even a trained and organized civilian labor, all of which should make our future economic struggles easier.

French officers and soldiers who have throughout the last two years been in contact with the American forces, working beside them will, it is to be hoped, have watched with interest and profit the fashion in which these have accomplished their tasks.

The eminently aggressive spirit which the American soldier brings with him to the firing line will not have failed to impress our French observers, nor will the effort made by each commander to develop the physical and moral qualities of his men have passed unnoticed.

In this connection, one question may be asked:

"Why was the American officer unready to profit by 
the veterans' experience, unless he found that it accorded with his own?"

To this we may reply that, with the mentality of this new army, each individual chief, to gain and maintain ascendancy over his men, was obliged to show an unflinching confidence in his own personal ability.

The men also were eager to show their commander what they could do unaided. Both had the desire, perhaps unacknowledged, of owing to themselves above all that consciousness which the good soldier must ever possess - his superiority over the foe. Fine and martial spirit of a people that has never known defeat!

It is to be hoped that our army staff may remain in touch with American headquarters and continue to study the working methods of their associates of yesterday, their friends of the present and future. Our American comrades are certain to codify in their new Field Service Regulations a portion of that experience gained on the battle-fields of the great war.

The names of the officers upon whom this work will devolve are already known to us. We cannot for a moment doubt as to what their conclusions will be.

All have been trained in that school to which General Pershing belongs. The spirit of offensive warfare has permeated their tactical conceptions and will surely inspire their future writings.

As for ourselves, who have witnessed all that has been set down in these pages, we have endeavored to relate with perfect impartiality the events which are herein chronicled, convinced that the simple and unvarnished truth is the best homage we can ever render to the admirable effort of our brothers in arms.

Paris, July 4th. 


\section{APPENDIX I}

Following is the order of battle of the American Expeditionary Forces on December 1, 1918:

This date has been selected preferably to any other as being that of the most complete development and greatest numerical strength of the command.

In consulting this document, it should be borne in mind that, as a consequence of numerous promotions and new assignments, on the one hand many American officers had had for a very short time the ranks and employments with which their names are herein associated; on the other hand, many others had, at that time, been but recently transferred from positions which they held for a long period in the course of the war.

Finally, the lack of available space has compelled the writers, much to their regret, to limit themselves to the troops in the field and omit those permanently assigned to the Services of Supply.

\section{ORDER OF BATTLE OF THE AMERICAN EXPEDI- TIONARY FORCES AT THE DATE OF DECEMBER I, I9I8}

\section{General Headquarters}

\section{American Expeditionary Forces}

General John J. Pershing........... Commanding Major-General James W. McAndrew .... Chief of Staff Brigadier-General LeRoy Eltinge........ Deputy Chief of Staff Lieutenant-Colonel Albert S. Kuegle..... Secretary-General Staff Brigadier-General Avery D. Andrews..... Asst. C. of S., G-I Brigadier-General Dennis E. Nolan..... Asst. C. of S., G-2 Brigadier-General Fox Connor.........Asst. C. of S., G-3 Brigadier-General George V. H. Moseley.Asst. C. of S., G-4 Brigadier-General H. B. Fiske.........Asst. C. of S., G-5 
Major-General Ernest Hinds .......... Chief of Artillery Major-General Mason M. Patrick...... Chief of Air Service Brigadier-General S. D. Rockenbach..... Chief of Tank Corps

\section{FIRST ARMY}

Lieutenant-General Hunter Liggett.... Commanding Brigadier-General Hugh A. Drumm... Chief of Staff Colonel Leon B. Kromer............ Asst. C. of S., G-I Colonel Willey Howell ............. Asst. C. of S., G-2

Colonel Lawrence Halstead........... . Asst. C. of S., G-3

Colonel John L. DeWitt............ Asst. C. of S., G-4

Colonel Lewis H. Watkins........... Asst. C. of S., G-5

Major-General William S. McNair.... Chief of Artillery

FIRST ARMY CORPS:

Major-General William M. Wright... Commanding

Colonel Walter S. Grant............ Chief of Staff

Major Lemuel L. Bolles............. Asst. C. of S., G-I

Lieutenant-Colonel Noble B. Juah..... Asst. C. of S., G-2

Lieutenant-Colonel Royden E. Beebe... Asst. C. of S., G-3

Lieutenant-Colonel C. A. Selleck...... Atg. Chief of Artillery

ThirTy-SiXth Division:

Major-General William R. Smith..... Commanding

Colonel Ezekiel J. Williams.......... Chief of Staff

\section{Ist Infantry Brigade}

Brigadier-General Pegram Whitworth...Comdg.

Colonel Luther H. James............ Comdg., I 4Ist Regt. Inf. Colonel Alfred W. Bloor............. Comdg., I42d Regt. Inf.

\section{2d Infantry Brigade}

Brigadier-General John A. Hulen....... Comdg.

Colonel Irving J. Phillipson............ Comdg., I43d Regt.

Colonel Oscar E. Roberts.............. Comdg., 144th Regt.

6Ist Field Artillery Brigade

Brigadier-General John E. Stephens..... Comdg.

Colonel Claud V. Birkhead...........Comdg., I3 Ist Rgt. F.A. 
Colonel Arthur R. Sholars............Comdg., I32d Rgt. F.A. Colonel Fred A. Logan............. Comdg., I33d Rgt. F.A.

Seventy-eighth Division:

Major-General James H. McRae....... Commanding

Colonel Charles D. Herron............ of S.

\section{I55th Infantry Brigade}

Brig.-General Sanford D. Stanberry... Comdg.

Colonel John M. Morgan........... Comdg., 309th Regt. Inf. Colonel Walter C. Babcock.......... Comdg., 3Ioth Regt. Inf.

\section{6th Infantry Brigade}

Brigadier-General James T. Dean....... Comdg.

Colonel Marcus B. Stokes............. Comdg., 3i Ith Regt.

Colonel Alvord V. P. Anderson......... Comdg., 312th Regt.

\section{I53d Field Artillery Brigade}

Brigadier-General Clint C. Hearn..... Comdg.

Colonel A. G. Fisher............. Comdg., 307th Rgt. F. A.

Colonel Chas. M. Bunker........... Comdg., 308th Rgt. F. A.

Colonel Edwin O. Sarratt.......... Comdg., 309th Rgt. F. A.

Eightieth Division :

Major-General Samuel D. Sturgis.... Commanding

Colonel William H. Waldron....... C. of S.

\section{I59th Infantry Brigade}

Brigadier-General Geo. H. Jamerson. . Comdg.

Colonel Chas. Keller.............. Comdg. 31 7th Regt. Inf.

Colonel Harry C. Jones............. Comdg. 318th Regt. Inf.

\section{I6oth Infantry Brigade}

Brigadier-General Lloyd M. Brett.... Comdg.

Colonel James M. Love............ Comdg. 319th Regt. Inf.

Colonel Ephraim C. Peyton.......... Comdg. 320th Regt. Inf.

\section{I55th Field Artillery Brigade}

Brigadier-General James H. Bryson...Comdg.

Colonel O. L. Brunzell............. Comdg. 313th Regt. F. A. 


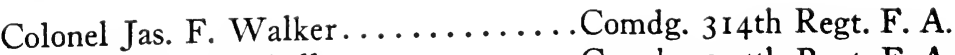

Colonel Wm. Tidball..............Comdg. 3I5th Regt. F. A.

FIFTH ARMY CORPS:

Major-General Charles P. Summerall...Commanding Brigadier-General Wilson B. Burtt..... Chief of Staff

Lt.-Colonel Albert W. Foreman.........Asst. C. of S., G-1

Lt.-Colonel George M. Russell......... Asst. C. of S., G-2

Colonel T. H. Emerson...............Asst. C. of S., G-3

Brigadier-General Dwight E. Aultman. .Comdg. Corps Artillery

Twenty-sixth Division:

Major-General Harry C. Hale...... Commanding

Colonel Duncan K. Major......... Chief of Staff

\section{Ist Infantry Brigade}

Brigadier-General L. L. Durfee........ Comdg.

Colonel Horace P. Hobbs. . . . . . . . . . Comdg. IOIst Regt. Inf. Colonel Hiram I. Bearss............ Comdg. I02d Regt. Inf.

\section{2d Infantry Brigade}

Brigadier-General Geo. H. Shelton....... Comdg.

Lieut.-Colonel Cassius M. Dowell........ Comdg. 103d Regt.

Colonel B. Frank Cheatham............ Comdg. 104th Regt.

5Ist Field Artillery Brigade

Brigadier-General P. D. Glassford..... Comdg.

Colonel Robert E. Goodwin.......... Comdg. rorst Regt. F. A.

Colonel J. A. Mack............... Comdg. IO2d Regt. F. A.

Colonel J. Alden Twachtman.........Comdg. 103d Regt. F. A.

Twenty-ninth Division :

Major-General Charles G. Morton...... Commanding

Colonel S. A. Cloman............... Chief of Staff

57th Infantry Brigade

Brigadier-General Leroy S. Upton.......Comdg.

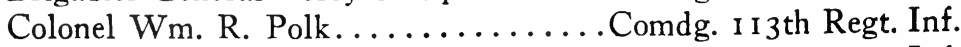

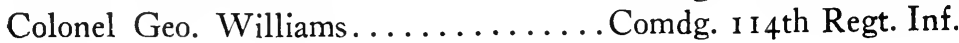




\section{8th Infantry Brigade}

Colonel John McKay Palmer.......... Comdg. Temp.

Colonel Milton A. Reckord........... Comdg. I 5 th Regt. Inf. Colonel Reginald H. Kelley........... Comdg. I I6th Regt. Inf.

\section{4th Field Artillery Brigade}

Brigadier-General Lucius R. Holbrook... Comdg.

Colonel Washington Bowie............. Comdg. I Ioth F. A.

Colonel Wm. F. Jones................ Comdg. II Ith F. A.

Colonel Quincy A. Gillmore............ Comdg. I I2th F. A.

\section{Eighty-SeCond Division:}

Major-General George B. Duncan..... Commanding Colonel Gordon Johnson............ C. of S.

\section{I63d Infantry Brigade}

Brigadier-General Marcus D. Cronin... Comdg.

Colonel Walter M. Whitman......... Comdg. 325th Regt. Inf. Colonel Pierce A. Murphy........... Comdg. 326th Regt. Inf.

\section{I64th Infantry Brigade}

Brigadier-General Julian R. Lindsey..... Comdg.

Lieut.-Colonel Frank W. Blalock........ Comdg. 327th Regt.

Colonel Richard Wetherill............ Comdg. 328th Regt.

\section{7th Field Artillery Brigade}

Brigadier-General Daniel F. Craig..... Comdg.

Colonel Earl D. Pierce.............Comdg. 319th Regt. F. A. Colonel Harry C. Williams.......... Comdg. 320th Regt. F. A. Lieut.-Colonel Churchill B. Meahard. . Comdg. 32 Ist Regt. F. A.

\section{EIGHTH ARMY CORPS:}

Major-General Henry T. Allen......... Comdg. Colonel George C. Marshall............. of S. Lieut.-Col. William B. Graham.......... Asst. C. of S., G-I Major Thom C. Catron...............Asst. C. of S., G-2 Colonel Hjalmer Erickson...............Asst. C. of S., G-3 
Sixth Division:

Major-General Walter H. Gordon....... Commanding Colonel Joseph W. Beacham............ Chief of Staff

\section{It Ith Infantry Brigade}

Brigadier-General Wm. R. Dashiell..... Comdg. Colonel Thos. H. Slavens.............. Comdg. 5 Ist Regt. Colonel Ernest V. Smith............. Comdg. 52d Regt.

\section{I2th Infantry Brigade}

Brigadier-General James B. Erwin....... Comdg.

Colonel Frederick G. Stritzinger......... Comdg. 53d Regt.

Colonèl Matthias Crowley............. Comdg. 54th Regt.

\section{6th Field Artillery Brigade}

Brigadier-General Edward A. Miller..... Comdg.

Colonel Willard D. Newbill..........Comdg. 3d Regt.

Colonel W. G. Peace.............. Comdg. I I th Regt.

Colonel Samuel Frankenberger......... Comdg. 78th Regt.

\section{Seventy-Seventh Division :}

Major-General Robert Alexander..... Commanding Colonel Clarence C. Scherrill......... C. of S.

\section{I53d Infantry Brigade}

Brigadier-General Michael J. Lenihan.... Comdg.

Colonel Raymond Sheldon............Comdg. 305th Regt. Colonel George Vidmer..............Comdg. 306th Regt.

\section{4th Infantry Brigade}

Brigadier-General Harrison J. Price..... Comdg.

Colonel Eugene Houghton............ Comdg. 307th Regt. Colonel John R. R. Hannay........... . Comdg. 308th Regt.

\section{I52d Field Artillery Brigade}

Brigadier-General Manus McCloskey.... Comdg.

Lieut.-Colonel Wm. McCleave.........Comdg. 304th Regt.

Colonel Fred C. Boyle.............. Comdg. 305th Regt.

Colonel C. D. Winn............... Comdg. 306th Regt. 
Seventy-ninth Division :

Major-General Joseph E. Kuhn........ Commanding

Colonel Tenney Ross............... Chief of Staff

I57th Infantry Brigade

Brigadier-General John S. Winn........ Comdg.

Colonel C. B. Sweezey............... Comdg. 313th Regt.

Colonel Wm. H. Oury.............. Comdg. 31 $4_{\text {th Regt. }}$

158th Infantry Brigade

Brigadier-General Evan M. Johnson..... Comdg.

Colonel Alden C. Knowles............. Comdg. 315th Regt.

Colonel Garrison McCaskey............. Comdg. 316th Regt.

\section{I54th Field Artillery Brigade}

Brigadier-General Andrew Hero......... Comdg.

Colonel Howard Landers............. Comdg. 3 Ioth Regt.

Colonel Chas. Mortimer.............. Comdg. 3i I th Regt.

Colonel Harry P. Wilbur.............. Comdg. 312th Regt.

Eighty-FiRst Division :

Major-General Charles J. Bailey........ Commanding

Colonel Charles D. Roberts............ Chief of Staff

\section{I6Ist Infantry Brigade}

Brigadier-General Geo. W. McIver..... Comdg.

Colonel Frank Halstead.............. Comdg. 32 Ist Regt.

Colonel Lorain T. Richardson.......... Comdg. 322d Regt.

\section{I62d Infantry Brigade}

Brigadier-General Monroe McFarland...Comdg.

Colonel Thos. A. Pierce............... Comdg. 323d Regt.

Colonel Geo. W. Moses............... Comdg. 324th Regt.

\section{I56th Field Artillery Brigade}

Brigadier-General Andrew Moses.....Comdg.

Colonel R. P. Reeder............... Comdg. 3I6th F. A. Regt.

Colonel N. E. Margetts.............Comdg. 317th Regt.

Colonel J. P. Robinson..............Comdg. 318th Regt. 


\section{SECOND ARMY}

Lieutenant-General Robert L. Bullard. Commanding Brigadier-General Stuart Heintzelman.. Chief of Staff Colonel G. K. Wilson..............Asst. C. of S., G-I Lieutenant-Colonel C. F. Thompson.... Asst. C. of S., G-2 Colonel W. N. Haskell. ............. Asst. C. of S., G-3 Colonel George P. Tyner............Asst. C. of S., G-4 Colonel J. E. Bell. ................Asst. C. of S., G-5 Brigadier-General Dwight E. Aultman.. Chief of Army Artillery SIXTH CORPS:

Major-General Charles T. Mencher.... Commanding Colonel Edgar T. Collins.......................... of Staff Colonel Charles H. Bridges........... Asst. C. of S., G-I Lieut.-Colonel Samuel T. Mackall..... Asst. C. of S., G-2 Colonel George F. Baltzell. ..........Asst. C. of S., G-3 Brigadier-General Albert J. Bowley.... Chf. of Cps. Artillery

\section{Seventh Division:}

Major-General Edmund Wittenmyer.... Commanding Lieutenant-Colonel H. A. Parker........ Chief of Staff

\section{I3th Infantry Brigade}

Brigadier-General A. W. Bjornstad...... Comdg. Colonel Jas. V. Heidt.............. Comdg. 55th Regt. Inf. Colonel Arthur L. Bump............ Comdg. 56th Regt.

\section{I4th Infantry Brigade}

Brigadier-General Lutz Wahl ......... Comdg.

Colonel Fred L. Munson............. Comdg. 34th Regt. Colonel Edson A. Lewis............. Comdg. 64th Regt.

\section{7th Field Artillery Brigade}

Brigadier-General Pienann N. Horn..... Comdg.

Colonel Harrison Hall.............. Comdg. 8th Regt.

Colonel Edgar A. Sirmyer. . . . . . . . . . . Comdg. 79th Regt.

Colonel F. W. Stopford........... Comdg. 8oth Regt. 
Twenty-eighth Division:

Major-General William H. Hay........ Commanding Colonel Walter C. Sweeney............ Chief of Staff

\section{5th Infantry Brigade}

Brigadier-General Wilds P. Richardson. Comdg.

Colonel A. F. Prescott.............. Comdg. Iogth Regt. Colonel Samuel V. Ham............. Comdg. I Ioth Regt.

56th Infantry Brigade

Brigadier-General H. A. Allen.......... Comdg.

Colonel C. F. Armistead.............. Comdg. II It Regt. Colonel Geo. C. Richards.............. Comdg. I I2th Regt.

\section{3d Field Artillery Brigade}

Brigadier-General William G. Price..... Comdg.

Colonel Richard C. Burleson........... Comdg. 107th Regt. Colonel Franc Lacocq............... Comdg. 108th Regt. Lieutenant-Colonel H. H. Fuller........ Comdg. 109th Regt.

Ninety-Second Division :

Major-General Charles H. Martin...... Commanding Colonel Allen J. Greer.............. Chief of Staff

\section{I83d Infantry Brigade}

Brigadier-General Malvern H. Barnum. .Comdg.

Colonel Hunter B. Nelson............. Comdg. 365th Regt. Colonel Ralph B. Parrott............. Comdg. 366th Regt.

\section{I84th Infantry Brigade}

Brigadier-General Albert H. Blanding... Comdg.

Colonel Wm. G. Doane.............. Comdg. 367th Regt.

Colonel Fred R. Brown.............. Comdg. 368th Regt.

\section{I67th Field Artillery Brigade}

Brigadier-General John H. Sherburne. .Comdg.

Colonel John O'Neil............... Comdg. 349th Regt. F.A.

Colonel Walter E. Prosser............Comdg. 350th Regt.

Colonel W. H. Carpenter............Comdg. 35 Ist Regt. 
NINTH ARMY CORPS:

Major-General Adelbert Cronkhite..... Comdg.

Brigadier-General W. K. Naylor....... Chief of Staff

Lieutenant-Colonel Dabney Ward....... Asst. C. of S., G-I

Lieutenant-Colonel Miles Sherman..... Asst. C. of S., G-2

Lieutenant-Colonel H. R. Richmond.... Asst. C. of S., G-3

Brigadier-General R. P. Davis.........Comdg. Corps Artillery

ThirTY-THIRD Division :

Major-General George Bell........... Comdg.

Lieutenant-Colonel William H. Simpson. . Chief of Staff

65th Infantry Brigade

Brigadier-General Edward L. King...... Comdg.

Colonel Edgar A. Myer. . . . . . . . . . . Comdg. I 29th Rgt. Inf.

Colonel John B. Clinnin............. Comdg. I 30th Regt.

66th Infantry Brigade

Brigadier-General Paul E. Wolfe........Comdg.

Colonel Joseph B. Sanborn............ Comdg. I3 Ist Regt.

Colonel Abel Davis...................... 132d Regt.

58th Field Artillery Brigade

Brigadier-General Henry Todd, Jr...... Comdg.

Colonel Milton J. Forman........... Comdg. 122d Regt.

Colonel Chas. B. Davis................ Comdg. 123d Regt.

Colonel Horatia B. Hackett. . . . . . . . Comdg. 124th Regt.

Thirty-Fifth Division:

Major-General Peter E. Traub........ Commanding Colonel Hamilton S. Hawkins.......... Chief of Staff

\section{6gth Infantry Brigade}

Brigadier-General Thomas W. Darrah... Comdg.

Colonel Ira L. Reeves.............. Comdg. I37th Regt. Col. Americus Mitchell............. Comdg. 138th Regt.

\section{7oth Infantry Brigade}

Brigadier-General Thos. B. Dugan...... Comdg.

Colonel Carl L. Ristine... . . . . . . . . Comdg. I39th Regt. Colonel Alonzo Gray............... Comdg. I 40th Regt. 
6oth Field Artillery Brigade

Brigadier-General Lucien G. Berry. . Comdg.

Colonel Geo. A. Taylor........... Comdg. I28th F. A. Regt.

Colonel Karl D. Klemm........... Comdg. I29th Regt.

Colonel Hugh S. Brown.......... Comdg. 130th Regt.

\section{THIRD ARMY}

Major-General Joseph T. Dickman...... Commanding Brigadier-General Malin Craig......... Chief of Staff Colonel James A. Logan............... Asst. C. of S., G-I Colonel R. H. Williams.............. Asst. C. of S., G-2 Colonel John C. Montgomery............ Asst. C. of S., G-3 Lieutenant-Colonel J. H. Perkins......... Asst. C. of S., G-4 Colonel Walter C. Short.............. Asst. C. of S., G-5

THIRD CORPS:

Major-General John L. Hines......... Commanding Brigadier-General Campbell King........ Chief of Staff Lieutenant-Colonel M. C. Shallenburger. . Asst. C. of S., G-I Lieutenant-Colonel Horace C. Stebbins... Asst. C. of S., G-2 Colonel Adna H. Chaffee.............. Asst. C. of S., G-3

Second Division:

Brigadier-General John A. Lejeune...... Commanding Colonel H. B. Myers................ Chief of Staff

\section{3d Infantry Brigade}

Brigadier-General Charles E. Kilbourne. .Comdg.

Colonel Robert O. VanHorn............ Comdg. 9th Regt.

Colonel Edward R. Stone.............. Comdg. 23d Regt.

4th Infantry Brigade

Brig.-General Wendell C. Neville.... Comdg.

Colonel Logan H. Feland..........Comdg. 5th Regt. Marines Colonel Harry Lee.............. Comdg. 6th Regt. Marines 


\section{2nd Field Artillery Brigade}

Colonel Dan T. Moore.............. Comdg.

Colonel David McC. McKell...........Comdg. 12th Regt.

Colonel J. P. Davis................ Comdg. 1 5th Regt.

Colonel Robert H. Dunlap............Comdg. 17th Regt.

Thirty-second Division :

Major-General William Lassiter........ Commanding

Colonel Robert McC. Beck........... Chief of Staff

\section{3d Infantry Brigade}

Brigadier-General Wm. R. Smedburg.... Comdg.

Colonel Edgar G. Heckel............ Comdg. 125th Regt. Major Guy M. Wilson............. Comdg. 126th Regt.

\section{4th Infantry Brigade}

Brigadier-General Edmund B. Winans... Comdg.

Colonel Russell C. Langden............ Comdg. 127th Regt. Lieutenant-Colonel Henry A. Meyer..... Comdg. 128th Regt.

\section{6th Field Artillery Brigade}

Brigadier-General Johnson Hagood....... (Ord. to command) Colonel Conrad H. Lanza............ Comdg.

Colonel Phillip H. Worcester.......... Comdg. 146th Regt.

Colonel Boyd Wales.............. Comdg. 147th Regt. Colonel Marion S. Battle............. Comdg. 148th Regt.

FORTY-SECOND Division :

Major-General C. A. F. Flagler........ Commanding Colonel William N. Hughes........... Chief of Staff

\section{3d Infantry Brigade}

Brigadier-General Frank M. Caldwell... Comdg.

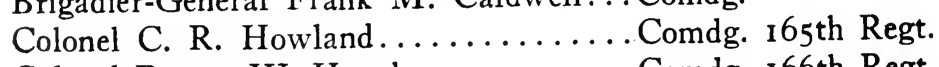
Colonel Benson W. Hough............. Comdg. 166th Regt.

\section{4th Infantry Brigade}

Brigadier-General Douglas McArthur...Comdg. Colonel Wm. P. Screws............. Comdg. 167th Regt. Colonel Matthew A. Tinley............. Comdg. 168th Regt. 


\section{7th Field Artillery Brigade}

Brigadier-General George G. Gatley..... Comdg.

Colonel Henry J. Rielly.............. Comdg. I49th Regt.

Colonel Robert H: Tyndall............ Comdg. I 5oth Regt.

Colonel Geo. E. Leach............... Comdg. I5Ist Regt.

FOURTH CORPS:

Major-General Charles H. Muir........ Commanding

Brigadier-General Briant H. Wells...... Chief of Staff

Lieutenant-Colonel Mack Garr.......... Asst. C. of S., G-I

Lieutenant-Colonel Joseph Stilwell...... Asst. C. of S., G-2

Colonel Berkeley Enochs.............. Asst. C. of S., G-3

Brigadier-General Wm. M. Cruikshank. .Chief of Corps Art.

First Division:

Major-General E. F. McGlachlan....... Commanding Colonel Stephen O. Fuqua............ Chief of Staff

\section{Ist Infantry Brigade}

Brigadier-General Frank Parker........ Comdg.

Colonel W. F. Harrell............... Comdg. I6th Rgt. Inf. Col. C. A. Hunt................. Comdg. I8th Regt.

\section{2d Infantry Brigade}

Brigade-General F. C. Marshall......... Comdg.

Lieutenant-Colonel Theodore Roosevelt..Comdg. 26th Regt.

Lieutenant-Colonel T. W. Hammond.... Comdg. 28th Regt.

\section{Ist Field Artillery Brigade}

Brigadier-General Henry W. Butner..... Comdg.

Colonel C. L. Corbin................. Comdg. 5th F. A. Rgt. Colonel Wm. H. Dodds.............. Comdg. 6th F. A. Rgt.

Colonel Francis Ruggles............. Comdg. 7th Rgt.

ThiRD Division :

Major General Robert L. Howze........ Commanding

Colonel Robert McCleave............ Chief of Staff 


\section{5th Infantry Brigade}

Brigadier-General Fred W. Sladen..... Comdg.

Colonel Geo. R. Herbst............. Comdg. 4th Inf. Regt. Colonel Wm. M. Morrow........... Comdg. 7th Inf. Regt.

\section{6th Infantry Brigade}

Brigadier-General Ora E. Hunt........ Comdg.

Colonel Howard R. Perry........... Comdg. 30th Regt. Colonel Frank H. Adams............. Comdg. 38th Regt.

3rd Field Artillery Brigade

Brigadier-General Harry G. Bishop..... . Comdg.

Colonel Chas. Reese Lloyd............ Comdg. Ioth Regt. Lieutenant-Colonel Ronald B. Johnson... Comdg. I 8th Regt. Colonel E. St. J. Greble.............Comdg. 76th Regt.

Fourth Division :

Major General Mark L. Hersey........ Commanding Colonel Christian A. Bach............ Chief of Staff

\section{7th Infantry Brigade}

Brigadier-General Benjamin A. Poore.... Comdg.

Colonel Frank C. Bolles..... . . . . . . Comdg. 39th Regt. Colonel Troy H. Middleton.......... Comdg. 47th Regt.

8th Infantry Brigade

Brigadier-General Ewing E. Booth....... Comdg.

Colonel O. P. M. Hazzard............ Comdg. 58th Regt. Colonel F. M. Wise. . . . . . . . . . . Comdg. 59th Regt.

4th Field Artillery Brigade

Brigadier-General Edwin B. Babbitt..... Comdg.

Colonel Wright Smith ............ Comdg. 13th Regt. Colonel Henning F. Colly............ Comdg. 16th Regt. Colonel Archibald F. Comiskey......... Comdg. 77th Regt.

SEVENTH CORPS:

Major-General Wm. G. Haan.........Commanding

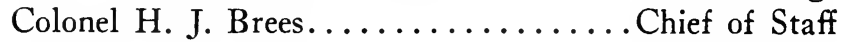
Colonel Clifford Game............Asst. C. of S., G-I 
Major Elmer F. Rice............... Asst. C. of S., G-2

Colonel Roger S. Fitch............... Asst. C. of S., G-3

Major F. J. Dunnigan............. Corps Artillery Cdr.

Fifth Division :

Major General Hanson E. Ely.......... Commanding

Colonel Clement A. Trott............ Chief of Staff

\section{9th Infantry Brigade}

Brigadier-General Jos. G. Castner....... Comdg.

Colonel Frank B. Hawkins............. Comdg. 6oth Regt. Colonel Phillip B. Peyton............. Comdg. 6ist Regt.

\section{Ioth Infantry Brigade}

Brigadier-General Paul B. Malone....... Comdg.

Colonel Henry J. Hunt.............. Comdg. 6th Regt.

Colonel Robert H. Peck............. Comdg. I I th Regt.

\section{5th Field Artillery Brigade}

Brigadier-General Wm. C. Rivers....... Comdg.

Lieutenant-Colonel Wm. E. Dunn...... Comdg. 19th Regt.

Colonel Brooke Payne............... Comdg. 2oth Regt.

Colonel Richard H. McMaster.......... Comdg. 2 Ist Regt.

EightY-NINTH Division:

Major-General Frank L. Winn......... Commanding

Colonel John C. H. Lee............. Chief of Staff

\section{I77th Infantry Brigade}

Brigadier-General Herman Hall........ Comdg.

Colonel James H. Reeves.............. Comdg. 353d Regt.

Colonel Conrad S. Babcock............ Comdg. 354th Regt.

\section{I78th Infantry Brigade}

Brigadier-General Geo. C. Barnhardt.... Comdg.

Colonel Wm. A. Cavanaugh............ Comdg. 355th Regt.

Colonel Robert H. Allen.............. Comdg. 356th Regt. 


\section{I64th Field Artillery Brigade}

Brigadier-General Edgar T. Donnelly.... Comdg.

Colonel Ernest Wheeler.............Comdg. 340th Regt.

Colonel Robert Davis............... Comdg. 34Ist Regt.

Colonel Earle Biscoe.............. Comdg. 342d Regt.

Ninetieth Division:

Major-General Leroy S. Lyon......... Commanding Colonel John J. Kingman............ Chief of Staff

\section{I79th Infantry Brigade}

Brigadier-General Jos. T. O'Neil........ Comdg.

Colonel Edgar T. Hartman. . . . . . . . . Comdg. 357th Regt. Colonel Woodson Hocker............. Comdg. 358th Regt.

\section{I8oth Infantry Brigade}

Brig.-Gen. Ulysses G. McAlexander..... Comdg.

Colonel E. Kearsley Sterling. ......... Comdg. 359th Regt. Colonel Howard C. Price.............. Comdg. 36oth Regt.

\section{I65th Field Artillery Brigade}

Colonel R. S. Abernathy............. Comdg. Temp.

Colonel Henry B. Farrar. . . . . . . . . . . Comdg. 343d Regt.

Colonel A. U. Falkner. . . . . . . . . . . Comdg. 344th Regt.

Colonel G. L. Wertenbaker... . . . . . . . Comdg. 345th Regt.

\section{UNASSIGNED}

SECOND ARMY CORPS:

Major-General George W. Read........ Commanding Brigadier-General George S. Simonds.... Chief of Staff

Colonel Richard K. Hale. . . . . . . . . . . Asst. C. of S., G-I

Colonel Kerr T. Riggs............... Asst. C. of S., G-2

Colonel Fred E. Buchanan. . . . . . . . . . Asst. C. of S., G-3

Colonel John P. Terrell. .............Asst. C. of S., G-4

Twenty-Seventh Division:

Major-General John F. O'Ryan........ Commanding Colonel Stanley H. Ford............ Chief of Staff 


\section{3d Infantry Brigade}

Brigadier-General Charles I. DeBevoise. .Comdg.

Colonel James M. Andrews............ Comdg. 105th Regt. Colonel Franklin W. Ward............ Comdg. 106th Regt.

\section{4th Infantry Brigade}

Brigadier-General Palmer E. Pierce...... Comdg.

Colonel Mortimer D. Bryant........... Comdg. Io7th Regt. Colonel Edgar S. Jennings............. Comdg. 108th Regt.

\section{2d Field Artillery Brigade}

Brigadier-General George A. Wingate.... Comdg.

Colonel Charles C. Pulis.............. Comdg. 104th Regt.

Colonel DeWitt C. Weld.............. Comdg. 105th Regt.

Colonel E. P. Smith................ Comdg. 106th Regt.

Thirtieth Division:

Major-General Edward M. Lewis....... Commanding

Colonel John K. Herr............... Chief of Staff

59th Infantry Brigade

Brigadier-General L. D. Tyson.......... Comdg.

Colonel Carey F. Spence.............. Comdg. i 7 th Regt.

Colonel Orren R. Wolfe............. Comdg. i 18th Regt.

6oth Infantry Brigade

Brigadier-General S. L. Faison......... Comdg.

Colonel J. Van B. Metts.............. Comdg. I Igth Regt.

Colonel Sidney B. Minor.............. Comdg. 1 2oth Reg..

55th Field Artillery Brigade

Brigadier-General John W. Kilbreth..... Comdg.

Colonel Albert L. Cox............... Comdg. I 1 3th Regt.

Colonel Luke Lee.................. Comdg. I 1 $4^{\text {th Regt. }}$

Colonel Harry S. Berry.............. Comdg. I1 5 th Regt.

\section{ThirTy-Seventh Division:}

Major-General Charles S. Farnsworth.... Commanding Colonel Dana T. Merrill............. Chief of Staff 
Brigadier-General Wm. M. Fassett...... Comdg.

Colonel Frank C. Gerlach............. Comdg. 145th Regt.

Colonel James M. Pickering........... Comdg. 146th Regt.

74th Infantry Brigade

Brigadier-General W. P. Jackson....... Comdg.

Colonel Frederick W. Galbraith........ Comdg. 147th Regt.

Colonel Geo. W. Stewart............ Comdg. I 48th Regt.

\section{2d Field Artillery Brigade}

Brigadier-General Edward Burr........ Comdg.

Colonel Harold M. Bush............ Cdg. 134th F. A. Rgt.

Colonel Dudley J. Hurd............ Cdg. 135th F. A. Rgt.

Colonel Paul L. Mitchell............ Comdg. I36th Regt.

Eighty-Seventh Division :

Brigadier-General Wm. F. Martin....... Commanding

Colonel Henry R. Richmond.......... Chief of Staff

I73d Infantry Brigade

Brigadier-General Marcus D. Cronin.... Comdg.

Colonel John O'Shea............... Comdg. 345th Regt.

Major George R. Byrd.............Comdg. 346th Regt.

\section{I74th Infantry Brigade}

Brigadier-General Wm. F. Martin....... Comdg. Div. Temp. Colonel Pearl M. Shaffer............Comdg. 347th Regt. Colonel Dwight W. Ryther........... Comdg. 348th Regt.

\section{I62d Field Artillery Brigade}

Brigadier-General John L. Hayden...... Comdg.

Colonel F. Wharton-Griffith........... Cdg. 334th F. A. Rgt.

Colonel Lewis S. Ryan.............. Comdg. 335th Regt.

Major Milton B. Taulbee........... Comdg. 336th Regt.

\section{Eighty-eighth Division :}

Major-General William Weigel........Commanding

Colonel Fay W. Brabson............ Chief of Staff 


\section{Appendix I}

I75th Infantry Brigade

Brigadier-General M. B. Stewart....... Comdg.

Colonel Girard Sturtevant............. Comdg. 349th Regt. Colonel Chas. B. Stone................ Comdg. 350th Regt.

I76th Infantry Brigade

Brigadier-General Wm. B. Beach....... Comdg.

Colonel Herbert B. Crosby............. Comdg. 35 Ist Regt. Colonel Clyde E. Hawkins............. Comdg. 352d Regt.

I63d Field Artillery Brigade

Brigadier-General Stephen M. Foote..... Comdg.

Colonel Geo. R. Greene................ Comdg. 337th Regt. Colonel Ned B. Rehkopf............. Comdg. 338th Regt. Colonel Samuel C. Vestal.............. Comdg. 339th Regt.

Ninety-first Division:

Major-General Wm. H. Johnston....... Commanding Colonel Henry C. Jewett.............. Chief of Staff

\section{I8Ist Infantry Brigade}

Brigadier-General John B. McDonald.... Comdg.

Colonel Avery D. Cummings........... Comdg. 36ist Regt. Colonel Jas. B. Woolnough............. Comdg. 362d Regt.

I82d Infantry Brigade

Brigadier-General Vernon A. Caldwell... Comdg.

Colonel Harry LaT. Cavanaugh......... Comdg. 363d Regt. Colonel Lucius C. Bennett............. Comdg. 364th Inf.

\section{I66th Field Artillery Brigade}

Brigadier-General Beverly F. Browne.... Comdg.

Lieutenant-Colonel G. S. Gay ........... Cdg. 346th F. A. Rgt. Colonel Louis E. Bennett............. Cdg. 347th F. A. Rgt. Colonel S. F. Bottom............... Cdg. 348th F. A. Rgt. 


\section{APPENDIX II}

\section{ORGANIZATIONS OF THE AMERICAN EXPEDI- TIONARY FORCES CITED IN GENERAL ORDERS BY THE FRENCH HIGH COMMAND ${ }^{1}$}

Third Infantry Brigade. In the course of operations north of the Marne, from June I, to July 2, I9I8, under the energetic and gallant leadership of its commander, General Lewis, and of its officers, without taking heed of heavy casualties valiantly supported, stormed the village of Vaux and La Roche Wood. It thus gave a splendid example of aggressive value and self-sacrifice, and took an important share in the victorious offensive, the result of which was to compel the enemy to evacuate the soil of France and to sue for an armistice.

Fourth Infantry Brigade (Marines). In the course of heavy fighting was rushed to a part of the front that was being violently attacked by the enemy and immediately proved itself a first-class fighting unit. No sooner entered into line than the brigade, in conjunction with French troops checked a violent attack launched on an important sector of our positions; and afterward, on its own account, undertook a succession of offensive operations in the course of which, thanks to the courage, energy, aggressiveness, and tenacity of its men who allowed themselves to be checked neither by hardships nor by losses, thanks to the activity and energy of its officers, and thanks especially to the personal action of its commander, General James G. Harbord, the efforts of the Fourth Brigade were crowned with success.

Operating in closest liaison, its two regiments and its machinegun battalion, after twelve days of incessant fighting (from June $2 \mathrm{~d}$ to June $13^{\text {th }}$ ) succeeded in making an advance of a mile to a mile and a half on a two mile and a quarter front over very diffi-

1 The citations printed herewith have been notified to the General Headquarters of the American Expeditionary Forces prior to April 15, 1919. 
cult ground, capturing during their advance important quantities of material and making over five hundred prisoners; they inflicted very severe losses on the enemy, took two strongholds of paramount importance: the village of Bouresches and the strongly fortified Belleau Wood.

Sixty-third Infantry Brigade. Composed of the 125 th and 126th Regiments covered itself with glory in the fighting around Juvigny on August 28, I9I8. Immediately upon arriving on the battle-field it assumed the offensive, surprised the enemy, whom it demoralized by the speed and vigor of its attack. The Sixty-third Brigade proved its superiority in terrible hand-to-hand fighting, from which it emerged victorious in spite of repeated enemy counter-attacks. It pushed back the foe to the vicinity of TernySorny and vanquished him, thus affording powerful aid to the French troops who were in close proximity during the attacks which took place from August 30th to September Ist.

Sixty-fourth Infantry Brigade. A splendid brigade to which the French soldiers fighting in its neighborhood paid the sincere tribute of calling it "The Terrible Brigade." Composed of the 127th and I28th Infantry Regiments, stormed the village of Juvigny on August 3oth with irresistible dash and on August 3 Ist and September Ist continued its advance, constantly maintaining its superiority over the enemy notwithstanding severe losses, checking most violent counter-attacks, and, fighting for three days without rest or pause, and almost without food.

5th Regiment of Infantry (Marines). Engaged unexpectedly in the offensive of July I8, 1918, during a very dark night on unknown and difficult ground, for two days it displayed remarkable vigor and tenacity without allowing itself to be discouraged either by hardships or difficulty of supply. It pushed back the enemy to a depth of seven miles, capturing 2,700 prisoners, twelve cannon, and several hundred machine guns. This regiment was commanded by Colonel Logan H. Feland.

5th Regiment of Infantry (Marines). Took a glorious part in the operations engaged in Champagne during October, 1918, by the Fourth Army. Participated on October 3d in the attack on the strong enemy positions between the White Hills and Medeah Farm; pushed forward to St. Etienne à Arnes, thus making an advance of three miles and a half. It captured several thousands 
of prisoners, cannon, machine guns, and important quantities of war material.

This attack, together with that of the French divisions, compelled the enemy to evacuate both banks of the Suippe and the high ground around Notre Dame-des-Champs.

6th Regiment of Infantry (Marines). Engaged unexpectedly in the offensive of July 18 , 1918, during a very dark night on unknown and difficult ground, for two days it displayed remarkable vigor and tenacity without allowing itself to be discouraged either by hardships or difficulty of supply. It pushed back the enemy to a depth of seven miles, capturing 2,700 prisoners, twelve cannon, and several hundred machine guns. This regiment was commanded by Colonel Logan H. Feland. Took a glorious part in the operations engaged in Champagne during October, 1918, by the Fourth Army. Participated on October $3 \mathrm{~d}$ in the attack on the strong enemy positions between the White Hills and Medeah Farm; pushed forward to St. Etienne à Arnes, thus making an advance of three miles and a half. It captured several thousands of prisoners, cannon, machine guns, and important quantities of war material. This attack, together with that of the French divisions, compelled the enemy to evacuate both banks of the Suippe and the high ground around Notre Dame-des-Champs.

gth Regiment of Infantry. Under command of Colonel Upton. Engaged unexpectedly in the offensive of July 18, 1918, during a very dark night on unknown and difficult ground, for two days it displayed remarkable vigor and tenacity without allowing itself to be discouraged either by hardships or difficulty of supply. It pushed back the enemy to a depth of seven miles, capturing 2,700 prisoners, twelve cannon, and several hundred machine guns.

gth Regiment of Infantry. Took a glorious part in the operations engaged in Champagne during October, 1918, by the Fourth Army. Participated on October $3 \mathrm{~d}$ in the attack on the strong enemy positions between the White Hills and Medeah Farm; pushed forward to St. Etienne à Arnes, thus making an advance of three miles and a half. It captured several thousands of prisoners, cannon, machine guns, and important quantities of war material. This attack, together with that of the French divisions, 
compelled the enemy to evacuate both banks of the Suippe and the high ground around Notre Dame-des-Champs.

I8th Regiment of Infantry. A splendid regiment of attack permeated with the spirit of offensive. On July I8, I918, under the energetic leadership of its commander, Colonel Frank Parker, it elicited the admiration of all the neighboring units in taking by storm all the objectives assigned to it absolutely without check and in spite of severe casualties. During the days following it continued to display the same aggressive spirit and determination. In October, 1918, under the excellent leadership of Colonel Charles A. Hunt, assisted by a body of officers of the first order, the i 8 th Regiment displayed the same qualities of abnegation, launching desperate attacks on powerful positions and, thanks to its indomitable will to conquer, succeeded at last in throwing back the enemy.

23d Regiment of Infantry. Engaged unexpectedly in the offensive of July 18, 1918, during a very dark night on unknown and difficult grounds, for two days it displayed remarkable vigor and tenacity without allowing itself to be discouraged either by hardships or difficulty of supply. It pushed back the enemy to a depth of seven miles, capturing 2,700 prisoners, twelve cannon, and several hundred machine guns. This regiment was commanded by Colonel Paul B. Malone.

23d Regiment of Infantry. Took a glorious part in the operations engaged in Champagne during October, 1918, by the Fourth Army. Participated on October $3 \mathrm{~d}$ in the attack on the strong enemy positions between the White Hills and Medeah Farm; pushed forward to St. Etienne à Arnes, thus making an advance of three miles and a half. It captured several thousands of prisoners, cannon, machine guns, and important quantities of war material.

28th Regiment of Infantry. Imbued with superb offensive spirit, on May 28, 1918, with Colonel H. E. Ely in command, attacked a strongly fortified village and with irresistible dash reached all objectives and retained the ground conquered in spite of repeated counter-attacks.

3oth Regiment of Infantry. One of the old original regiments of the American Army which, under the fine and energetic lead 
of its chief, Colonel E. L. Buth, proved true to its traditions, withstanding the main onslaught of the German attack of July I5, I918, on the front of the army corps to which it had been assigned. Under heavy artillery fire which entailed severe losses the 30th Regiment checked the enemy's drive and reëstablished its initial positions after capturing more than two hundred prisoners.

38th Regiment of Infantry. A crack regiment, under the clever and energetic leadership of its commander, Colonel McAlexander, displayed unshakable firmness in resisting the German assault of July 15, 1918. Attacked on its front and outflanked on both wings, it maintained its position on the banks of the Marne according to orders received to that effect and, in spite of everything, hurled back an enemy superior in numbers and captured two hundred prisoners.

39th Regiment of Infantry. Attached to a division entrusted with the defense of the sector, was called upon to take part in a battle on the day following its arrival in the line. Under the command of Colonel Frank C. Bolles displayed remarkable bravery in the course of its baptism of fire. It captured the Crêsnes Thickets, the town of Norroy, an enemy battery, important quantities of trench equipment, and machine guns together with over a hundred prisoners.

Io4th Regiment of Infantry. In the course of the fighting on

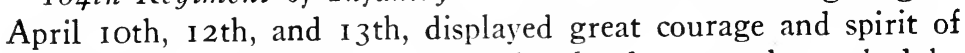
self-sacrifice. Subjected to heary bombardment and attacked by powerful German forces, it succeeded in checking a dangerous enemy advance, energetically counter-attacking with the bayonet and taking prisoners, recaptured the trenches which it had been forced to abandon in the course of the enemy's initial assault.

125th and 126th Regiments of Infantry. Are mentioned in general orders concerning the Sixty-third Brigade.

127th and 128th Regiments of Infantry. Are mentioned in orders concerning the Sixty-fourth Brigade.

369th Regiment of Infantry. Led by Colonel Hayward, who, though wounded, insisted on retaining command of his regiment during action, led by Lieutenant-Colonel Pickering, an officer of remarkable coolness and courage, by Major Cobb (killed), by Major Spencer (severely wounded), by Major Little, an excel- 
lent leader, the 369th Regiment of American infantry, which, in the September attacks of 1918 was, for the first time, under fire, captured strong and vigorously defended enemy entrenchments, stormed the village of Sechault, and took prisoners, six cannon, and large numbers of machine guns.

37 Ist Regiment of Infantry. Displayed, in the course of the first fighting in which it participated, all the qualities of daring and bravery characteristic of first-rate storm troops. Under command of Colonel Miles it launched, with fine dash and utter contempt of danger, an attack on an obstinately defended position, captured it after desperate fighting and under exceptionally heavy machine-gun fire. Continuing its advance, in spite of enemy artillery fire which entailed severe losses, captured many prisoners besides cannon, machine guns, and important quantities of material.

372d Regiment of Infantry. Displayed, in the course of the first fighting in which it participated, all the qualities of daring and bravery characteristic of first-rate storm troops. Under command of Colonel Tupes it launched, with fine dash and utter contempt of danger, an attack on an obstinately defended position, captured it after desperate fighting and under exceptional heavy machine-gun fire. Continuing its advance, in spite of enemy artillery fire which entailed severe losses, captured many prisoners besides cannon, machine guns, and important quantities of material.

I2th Regiment of Artillery. This regiment with remarkable audacity and skill assisted the Second Division's attack on July I 8 th southwest of Soissons, firing at close range. The guns were boldly pushed forward, following the advancing infantry and inflicted severe losses on the enemy.

After the relief of the infantry of the Second Division on July 2oth, the 12th Regiment valiantly fought side by side with the Fifty-eighth and Twelfth French Divisions, helping the infantry in the course of their unceasing attacks and more especially on July 2ist during the assault on Hartennes. Officers and enlisted men of the regiment showed themselves worthy, by their courage and devotion to duty, of the best traditions of their army.

I5th Regiment of Artillery. This regiment displayed great daring and remarkable skill in backing the infantry of the Second Division. On July 18, 1918, at the southwest of Soissons, pluckily 
pushing its guns ahead upon the heels of the advancing infantry, it inflicted extremely heavy losses on the enemy. The Second Division having been relieved on July 2oth, the I5th Regiment was successively ordered to sustain the Fifty-eighth and Twelfth French Divisions with which it valiantly fought, and in the course of the frequent counter-attacks launched by these two divisions and, more especially during the assault on Hartennes (July 2 Ist), officers and enlisted men of the regiment showed themselves worthy of the best traditions of their army through their gallantry and devotion.

I7th Regiment of Artillery. With untiring zeal and unflagging energy this regiment valiantly aided the attack of the Second Division on July i 8th southwest of Soissons. Always impatient to push forward the guns and in spite of heavy enemy bombardment, it constantly inundated the foe under a terrific destruction fire from its 155's. After the Second Division had been relieved on July 2oth, it remained in line sustaining the Fifty-eighth and Twelfth French Divisions.

Officers and enlisted men displayed remarkable energy in the courageous accomplishment of all the missions entrusted to them; during the continuous attacks launched by the French divisions they inflicted severe losses on the enemy, and displayed, amid dangers and hardships of all kinds, high valor and extraordinary tenacity.

2d Regiment of Engineers. With Colonel Mitchell in command. Engaged unexpectedly in the offensive of July 18, 1918, during a very dark night on unknown and difficult ground, for two days it displayed remarkable vigor and tenacity without allowing itself to be discouraged either by hardships or difficulty of supply. It pushed back the enemy to a depth of seven miles, capturing 2,700 prisoners, twelve cannon, and several hundred machine guns.

2d Regiment of Engineers. Played a glorious part in the operations undertaken in Champagne in October, 1918. On October $3 \mathrm{~d}$, during the attack on the White Hills and Medeah Farm, through its bravery and endurance under fire it powerfully aided in the advance of the infantry as far as St. Etienne à Arnes. Thanks to the great assistance which it afforded to the infantry operation it became possible to eject the enemy from the banks of 


\section{Appendix II}

the Suippe and from the high ground around Notre Dame-desChamps.

302d Regiment of Engineers. This regiment with Colonel Sherill in command on September 6, 1918, constructed a bridge over the Vesle in three hours, the work being carried out under constant artillery fire. The success of this feat rendered it possible for the French artillery to cross the river at the very start of operations and contributed to the success of the offensive then under way.

Ist Battalion of the Io2d Regiment of Infantry. A crack unit with Colonel Hiram J. Bears conducting the attack in first line, it carried out an extremely difficult operation in brilliant style and at the cost of splendid effort. It rushed aggressively into the battle and after desperate fighting triumphed over the enemy who was greatly superior in number and extremely tenacious, and who was, besides, entrenched in concrete shelters backed by great masses of machine guns and a powerful artillery, and who, in the course of action, made use of infamous methods of warfare. It heroically effected its mission, storning a village and maintaining its positions throughout the day notwithstanding four enemy counter-attacks, thus setting the finest example of self-sacrifice.

4th Machine-gun Battalion. On the evening of July 18, 1918, near Vierzy, this battalion displayed exceptional bravery and dash in assisting in the attack delivered by the Third Brigade. In the course of an advance with an attacking infantry and thanks to its skillful employment of fire, it overcame the resistance of the enemy. By the destruction of strongly enforced machine-gun nests it gave valuable help to the infantry in the course of the latter's brilliant attack and by occupying the objectives gained and holding them against powerful counter-attacks the Fourth Machine-gun Battalion made itself recognized as an important factor in the success of the day.

5th Machine-gun Battalion. On the evening of July 18, 1918, near Vierzy, this battalion displayed exceptional bravery and dash in assisting in the attack delivered by the Third Brigade. In the course of an advance with an attacking infantry and thanks to its skillful employment of fire, it overcame the resistance of the enemy. By the destruction of strongly enforced machine gun nests 
it gave valuable help to the infantry in the course of the latter's brilliant attack and by occupying the objective gained and holding them against powerful counter-attacks the Fourth Machine-gun Battalion made itself recognized as an important factor in the success of the day.

6th Machine-gun Battalion (Fourth Brigade, Second Division), was mentioned in general orders concerning the Fourth Brigade (Marines).

6th Machine-gun Battalion. Although exhausted by a long journey in trucks and a lengthy night march over difficult roads, this battalion, on July 18 , I918, rushed into battle in the vicinity of Vierzy and aided in consolidating the position captured that day. 'On the morning of the nineteenth it gallantly pushed forward in the open, under a rain of artillery and machine-gun fire, and helped resolutely in the assault which was being launched against the enemy's reënforced positions. Confronted with obstinate resistance and subjected to continuous counter-attacks it displayed the finest courage in rapidly organizing and resolutely holding the important positions which the infantry had just conquered.

7th Machine-gun Battalion (Third Division). Prevented the enemy from crossing the Marne, and in the course of fierce fighting, especially on May 3 Ist and June Ist, contested the northern suburbs of Château-Thierry foot by foot, covering itself with glory as much by its valor as by its skill, and inflicted tremendous losses upon the enemy.

IIgth Machine-gun Battalion. Fought for four days in the vicinity of Juvigny with energy, endurance, and skill. Although hard hit by the enemy bombardment it unceasingly pushed forward, keeping the foe under direct and accurate fire, checking his counterattacks, and inflicting upon him serious losses. It gave powerful assistance in the capture of Juvigny and also in retaining the conquered positions.

Ist Anti-aircraft Battalion. Under the able and efficient leadership of its commander, Major Cushing, made itself conspicuous through the excellent results achieved on the Marne and the Moselle by its bravery and fine spirit.

2d Field Signal Battalion (First Division). Having received 
orders to repair the telephone lines in a dangerous zone, carried out its mission with utmost bravery, working all night under a heavy bombardment of gas shells, which entailed severe losses.

The following organizations also obtained mention in the general orders of the French High Command:

Ist Battery, Ist Anti-aircraft Battalion.

Company F, 9th Regiment of Infantry.

Company G, 9th Regiment of Infantry.

Company I, 9th Regiment of Infantry.

Company L, 9th Regiment of Infantry.

Company C, 370th Regiment of Infantry.

Company B, 3oth Regiment of Engineers.

Company C, 56th Regiment of Engineers (Searchlights).

Battery D, i 7 th Regiment of Artillery.

Battery B, 53d Regiment of Artillery.

Battery H, 53d Regiment of Artillery.

308th Battery, Trench Artillery.

2d Platoon, Stokes Trench Mortars, IO2d Infantry.

2d Platoon, Company B, I68th Infantry.

Shenkel Platoon, Company B, i I ith Infantry.

Benz Platoon, Company A, I I ith Infantry.

Pioneer Platoon, Trench Mortar Battery, i68th Infantry.

Ist Platoon, Company B, I68th Infantry.

Ist Platoon, Company C, 308th Infantry.

2d Platoon, Company C, 308th Infantry.

Air Squadron 9I.

Air Squadron 94.

Air Squadron IO3 (Lafayette) three citations.

Sanitary Sections.

No. I, two citations.

No. 2.

No. 7.

No. 8, two citations.

No. 9 .

No. I 4 .
Sanitary Sections.

No. 585 .

No. 586.

No. 59I, two citations.

No. 593.

No. 594 .

No. 62I, two citations. 
No. 17.

No. 26.

No. 65.

No. 503.

No. 504 .

No. 5 I0.

No. 516, two citations.

No. 523, two citations.

No. 525 .

No. 533 .

No. 534, two citations.

No. 535 .

No: 539, two citations.

No. 544 .

No. 546 .

No. 553, two citations.

No. 558 .

No. 567 , two citations.

No. 568.

No. 583 .
No. 622.

No. 623, two citations.

No. 625, two citations.

No. 626, three citations.

No. 627.

No. 628, two citations.

No. 629, three citations.

No. 633, three citations.

No. 634 .

No. 635 .

No. 636, two citations.

No. 637.

No. 639 .

No. 641 .

No. 642 .

No. 643 .

No. 644 .

No. 645 .

No. 646, four citations.

No. 648 . 


\section{INDEX}

Accounting division of quartermaster corps, 228.

Adjutant-general, function of, in American forces in France, 4647.

Administrative section, of quartermaster corps, 228; of ordnance department, 233.

Aërial squadrons, formation of, 207; the Lafayette squadron, 207-208; mention of, in general orders of French high command, 419. See Aviation service.

Aëronautical school of American army in France, $7 \mathbf{I}$.

Aërostation, development of, by $\mathbf{A}$. E. F., 212-2I3.

Affiliated Divisions, $32 \mathrm{I}$.

Aircraft Production Board, creation of, 84 .

Airplanes, types of, 203-204; number of, received by A. E. F., 205.

Air service, organization of, in American army in France, 202208; system adopted for supplies and repairs, 208-2 ro. See Aviation.

Alexandre, General, in charge of Fifth American Corps artillery before St. Mihiel, 270.

Alien enemies in United States, detention of, $\mathbf{I r}$.

Allen, General Henry T., in command of Ninetieth Division, $252 \mathrm{n}$.

Allied Supply, Military Board of, 245 ; account of work of, 354358 ; summary of results secured by, 358-359.

Alvord, Benjamin, first adjutantgeneral of American forces in France, $46 \mathrm{n}$.

Ambulance companies, 22 I, 222.

Ambulance of Neuilly, 379 .

Ambulances donated by Americans, 380.

America, slowness of, in going to war, 1-2; Germany's inability to understand, 3 ; judged to desire "peace at any price," 4 ; review of causes leading to rupture with Germany, 5-10; declaration of war between Germany and, II ; unreadiness of, for war, 12; visit of French and English war missions to, 12-13; new energy given to conscription movement in, by visit of war missions, 13 ; preparation of armed forces for war, r3-32.

American Convalescent Homes, the, 382.

American Fund for French Wounded, 380 .

American Hostels for Refugees, creation of, 381 .

American Library Association, 363 , 370; work of, centralized by $Y$. M. C. A., 372; account of work of, $375-377$.

American Surgical Dressings Association, $38 \mathrm{r}$.

American Zone, section of French country called, 59-60.

Ammunition, used by A. E. F., 236238; pooling of, between Americans and French, 358.

Anamite soldiers as drivers for Americans, 174.

Ancona, Italian ship sunk in Mediterranean, 8.

Anderson, Colonel Alvord, V. P., $255 \mathrm{n}$.

Anderson, Colonel T. M., $156 \mathrm{n}$.

Andrew, Piatt H., service of field ambulances directed by, 380 .

Andrews, General Alvery D., $45 \mathrm{n}$.

Andrews, Colonel G. M., $324 \mathrm{n}$.

Angers, training center for heavy artillery at, 63 ; railway transportation school at, 76 .

Anti-aircraft battalion, cited in general orders by French high command, 418.

Anti-aircraft school, in France, 69. 
Arabic, sinking of, 8 .

Argonne Forest, operations between river Meuse and, in autumn of r918, 277-306; occurrence of most dramatic episodes of the war in, 295.

Arms equipment of American forces in France, 53-55.

Army, United States: condition of, upon declaration of war with Germany, 13-14; system of grouping of fighting units, 2932 ; Pershing's plans for organization of, in France, 36-37; martial qualities and military defects of Americans, 37-38; constitution of General Staff, 45-46; constitution of fighting units, $47-52$; plan for field army services, 52-53; arms and ordnance equipment of, 53-55; principles governing instruction of, 55-59; first appearance of American contingents in France, Ir6-128; operations of, in spring defensive (1918), 133167 ; in summer counter-offensive, I68-I84; account of organization of main services of Expeditionary Forces, $186 \mathrm{ff}$.; situation of, at beginning of September, 1918, 24726I; activities during general offensive September-November, 1918, 262-306; losses in MeuseArgonne fighting, 303 ; the march to the Rhine, 307-319; part taken by American units in operations on British front, 320-329; forces detached for operations in Italy and in Russia, 329-330; review of organization and activities of services of the rear, $33 \mathrm{I}-360$; order of battle of, on December $\mathbf{I}$, I918, 391-409; organizations of, cited in general orders by the French high command, 410-420.

Army corps, formation of, 48-49; command of, 52 .

Army schools in France, 63-70.

Artillery, camps for training officers for, 24; increase in number of regiments of, and shortage of equipment, $3 \mathrm{I}-32$; composition of divisional, in American army in France, 50-5I; camps selected in
France for training in, 60-63; rate of arrival of, in France, $6 \mathrm{I} \mathrm{n}$; army schools for training in, in France, 69-70; first use of American, on firing line in France, II9-120; functions of chief of, 189 ; account of organization, equipment, and composition of, 189-192; French admiration for American, 192; supply of material for, 236-237; situation of American, at beginning of September, I9r8, 259-260; situation of, before St. Mihiel, 271; in Meuse-Argonne operations, 282-284; regiments of, mentioned in general orders of French high command, 4rg.

Association, use made of free right of, in America, 361; colossal results achieved by American method of, 383 .

Athletic games, effort of Knights of Columbus to develop taste for, 373.

Atterbury, General, II3, 350; appointed director-general of transportation in France, ro5.

Aultman, General D. E., ${ }_{3} 8$ n., 154 $\mathrm{n}$.

Austin, Mrs., founder of American Surgical Dressings Association, $38 \mathbf{r}$.

Automobile service, 352; achievements in regard to, of Military Board of Allied Supply, 358-359.

Auto-surgical ambulances, French, $222 \mathrm{n}$.

Autun, military police corps training detachment at, 75 .

Averill, Colonel N. K., I7 I n.

Aviation, schools for training in, 72-74.

Aviation service, work of, to meet demands of war time, $84-85$; at time of Meuse-Argonne operations, $290 \mathrm{n}$. See also Air service.

Avord, aviation instruction center at, 72.

Aztec, sinking of the, ro n.

Babcock, Colonel Conrad S., 252 n. Babcock, Colonel Walter C., 255 n. 
Bacon, Robert, sanitary train donated by, 379-380.

Bailey, General Charles J., in command of Eighty-first Division, $258 \mathrm{n}$.

Baker, Newton D., Secretary of War, on the firing line, rzo-r $3 \mathbf{r}$; with General Pershing during operations against St. Mihiel, 272; enters St. Mihiel, 276-277; quoted on shipment of troops from America, 336; cargo movement, 337 .

Baker, Colonel, Salvation Army, 374 .

Bakeries, daily output of American, 230; bread supplied by, 350 .

Balloon service of A. E. F., 212213.

Ballou, General Charles C., in command of Ninety-Second Division, $254 \mathrm{n}$.

Baltzell, Colonel George F., $250 \mathrm{n}$.

Bandholtz, General H. H., 255 n.

Bangs, Miss Edith, $380 \mathrm{n}$.

Barber, Colonel A. E., I 55 n., 249.

Barney, Lieutenant James W., $251 \mathrm{n}$.

Barnum, General M. H., 254 n.

Barracks, erection of, by engineer corps, 198.

Barth, General C. H., in command of Seventh Division, $257 \mathrm{n}$.

Base sections of service of supplies, 34 I-349.

Bassens, as a base port for American use, 96 ; work on improvement of, 100-102; operated by Americans, 343 .

Bathélémont, tomb near, of first American killed in action, 120

Battalion, composition of a, 50 .

Beach, General W. O., $258 \mathrm{n}$.

Bears, Colonel Hiram J., 4I7.

Beatty, H. O., director of American Relief Clearing House, 382.

Bell, General George, in command of Thirty-third Division, $255 \mathrm{n}$.

Belleau Wood, taking of, by Second Division, 15I-153.

Benevolent associations under military authority, 318, 361-384.

Bennet, Colonel E. R., $160 \mathrm{n}$.

Bennet, Colonel John B., 253 n.
Berry, Major C. W., 324.

Berry, General L. G., 253 n

Bethel, General, head of judge-advocate's department, 244 .

Bevoise, Colonel C. T. de, $324 \mathrm{n}$.

Bjoranstad, General A. W., I73 n.

Blatchford, General R. M., in command of lines of communication, ro4.

Bliss, Mrs. Robert Woods, president of distributing committee, 380 .

Bliss, General Tasker H., represents America at Supreme War Council, r $34 \mathrm{n}$.

Bloor, Colonel A. W., $257 \mathrm{n}$.

Bolles, Colonel Frank C., 4r4.

Bolling, Colonel, $202 \mathrm{n}$.

Books sent to American army in France, 375-377.

Bordeaux, harbor for debarkation of American troops, 39; description of American base section of, 342-345.

Bowley, Colonel A. J., $147 \mathrm{n}$.

Boyd, Captain, United States military attaché in France, 92-94.

Bradley, General Alfred E., chief surgeon A. E. F., 219-220.

Brest, American base section at, 346.

Brett, General Lloyd M., $256 \mathrm{n}$.

Bridges, Colonel Charles H., $250 \mathrm{n}$.

Brigade, composition of a, 5o; command of, 51 .

Briggs, Colonel R. N., I7I n.

British front, American units on the, 320-329.

Brown, Colonel Fred R., 254 n.

Brown, Colonel M. D., $162 \mathrm{n}$.

Brown, General R. A., r6o n.

Browning guns used by American army in France, 54.

Buchan, Colonel F. E., 324 n.

Buck, General B. B., 138 n.

Bullard, General R. L., I17 ; takes command of First Division, I2I ; high morale of First Division as commanded by, 138 ; in command of Third Corps, 173, 249; in command on the Vesle, r81-r82; placed in command of Second Army, 296.

Bundy, General Omar, 117, 146 n.; in command of Second Division, 
122; in command of Sixth Corps, 250.

Burnham, General W. P., in command of Eighty-second Division, $252 \mathrm{n}$.

Burtt, General IV. B., $250 \mathrm{n}$.

Buth, Colonel E. L., in command of 3oth Regiment of Infantry, 414.

Buttle, Lt.-Col. G. M., 255.

Butts, Colonel Edmund L., $156 \mathrm{n}$.

Cadre Divisions in British army, $32 \mathrm{I}$.

Caldwell, Colonel V. A., 254 n.

Cambon, Jules, Councillor on Francb-American Affairs, 387.

Cameron, General George H., in command of Sixth Corps, 250; in command of Fifth Corps, 270.

Camouflage section of engineer service, 200.

Camps, establishment of training, 29 ; system of drilling in, 30 ; for training of American forces in France, 59-60; of embarkation, 86.

Candidates, school for, in France, 68.

Cargo movement from America, $336-338$.

Castelli, Chief Surgeon (French Army), 220.

Castner, General J. C., 253 n.

Catlin, Colonel A., $146 \mathrm{n}$.

Cavanaugh, Colonel $\mathrm{H}$. La $\mathrm{T}$., $257 \mathrm{n}$.

Cavanaugh, Colonel W. A., $252 \mathrm{n}$.

Cement supply for engineer service, 201 .

Cemeteries, American military, in Europe, 23 I-232.

Chamberlaine, General W., I47 n.; in command of American railroad artillery, $19 \mathrm{r}$.

Chapin, Mrs. Charles, $380 \mathrm{n}$.

Chaplains, school at Le Mans for instruction of, 76 .

Charles, Colonel Oscar J., $257 \mathrm{n}$.

Château-Thierry, work of Third Division at, 157-158.

Chaumont, American headquarters established at, 77 ; all heads of main services of American forces stationed for a time at, 186.

Chemical warfare, schools for, 75 .

Chemical warfare service of American army, 239; organization of, 240-242.

Chief of a rtillery, functions of, 189 .

Children of Flanders, work of the, 382.

Citations of organizations of American army by French high command, 410-420.

City of Memphis, sinking of, ron.

Civil War, benevolent associations at time of, $36 \mathrm{r}-362$.

Clark, Lt.-Col. Francis W., I73 n.

Clark, Colonel Paul H., 386 n.

Clarke, General Travers, member of Military Board of Allied Supply, $358 \mathrm{n}$.

Clémenceau, Premier, congratulates American soldiers after storming of Cantigny, 145 .

Clermont, training center for heavy artillery at, 63 .

Clinnin, Colonel J. V., $255 \mathrm{n}$.

Cobb, Major, killed in action, 4 r4.

Coblenz, occupation of, by Third Army, 314-3I 5 .

Cochon, Colonel Frank S., $256 \mathrm{n}$.

Coe, General, in command of American railroad artillery, r9r.

Coetquidan, American artillery training camp at, $6 \mathrm{r}, 62$; artillery aërial observation school at, 73.

Cold-storage plants, American, $343-344,347-348$.

Cole, General Charles H., I 54 n.

Colored officers, camps for instruction of, 28.

Colored troops, divisions composed of, $29 \mathrm{n}$.

Companies, composition of, $50 \mathrm{n}$.

Compulsory military service, pas. sage of act creating, 15 ; application of law, 16-22.

Connor, General W. D., $46 \mathrm{n}$., r70 n.; chief of coördination section, II2.

Construction and maintenance division of ordnance department, 234.

Corps, See Army corps. 
Corps schools in France, 70-72.

Corvisart, General, 127.

Council of National Defense, 332.

Courneau, American artillery training camp at, 62 .

Courts-martial, administration of military justice by American, 245.

Craig, Colonel Malin, $155 \mathrm{n}$.

Crawford, General C., I $56 \mathrm{n}$.

Cronin, General M. D., $252 \mathrm{n}$.

Cronkhite, General Adelbert, in command of Eightieth Division, $256 \mathrm{n}$.

Crookston, Lt.-Col. A. V., $162 \mathrm{n}$.

Crosby, Colonel H. B., 258 n.

Crowder, made Provost-Marshal General, r7.

Crowley, Colonel M., $254 \mathrm{n}$.

Cruikshank, Colonel Wm. M., $156 \mathrm{n}$.

Cumont, Major, Belgian member of Military Board of Allied Supply, $35^{8} \mathrm{n}$.

Cushing, Major, in command of Ist Battalion, 418.

Dabney, Lt.-Col. Ward S., $251 \mathrm{n}$.

Darrah, General T. W., r62 n.

Dashiell, General Wm. R., 254 n.

Davis, Colonel Abel, $255 \mathrm{n}$.

Davis, Colonel J. R., $147 \mathrm{n}$.

Davis, General Robert C., adjutant-general of American forces in France, $46 \mathrm{n}$.

Davis, Colonel Wm. D., $257 \mathrm{n}$.

Davison, H. P., president of Red Cross war committee for Europe, 368.

Dawes, General Charles G., head of General Purchasing Board, 356 ; service rendered by, 357 ; work of, on Military Board of Allied Supply, 358.

Dean, General James T., $255 \mathrm{n}$.

Deems, Colonel Clarence, Jr., 252 n.

Depot divisions, 48-49.

De Witt, Colonel J. L., 249 n.

Dickman, General Joseph T., in command of Third Division, 156 ; activities of, in spring defensive, 158,161 ; in command of Fourth Corps, 249, 269; in command of First Corps, 297.
Dillon, Colonel T. H., in command

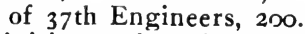

Divisions of United States Army, organization and composition of, 29-30; of army corps, 48-50; command of, $5 \mathbf{I}$; composition of the staff, 5i-52.

Dorey, Colonel Halstead, $156 \mathrm{n}$.

Doyle, Colonel Fred C., I7 I n.

Drumm, General Hugh A., 249 n.; chief of staff, 266, 267.

Duncan, General George B., I21, I $38 \mathrm{n}$.; in command of Seventyseventh Division, I7r.

Dutch ships, requisitioning of, 333334 .

Educational section of Y. M. C. A., 37 I.

Edwards, General Clarence, in command of Twenty-sixth Division, 124-125, $154 \mathrm{n}$.

Eightieth Division, in September, 1918, 256; operations of, on British front, $320 \mathrm{ff}$.

Eighty-first Division, in September, 1918, 258.

Eighty-second Division, order of battle in September, 1918, $252 \mathrm{n}$.; operations of, on British front, $320 \mathrm{ff}$.

Eighty-eighth Division, in September, 1918, $25 \mathrm{In}$.

Eighty-ninth Division, order of battle in September, 1918, $252 \mathrm{n}$.

Eltinge, General Le Roy, deputy chief of staff of American army, $45 \mathrm{n}$.

Ely, Colonel Frank D., 252 n.

Ely, Colonal Hanson E., $138 \mathrm{n}$., $145 \mathrm{n}$.; in command of 28th Regiment of Infantry, 4r3.

Emerson, Lt.-Col. T. H., $250 \mathrm{n}$.

Engineering division of ordnance department, 234.

Engineers, camps for training offcers for, 24; school for, in France, 66; increase in number of effectives, $85 \mathrm{n}$.; regiments of, assigned to transportation department in France, I14; duties of, 197-200; subdivisions of, 200201 ; quantities of material required by, 20I; regiments of, 
mentioned in general orders of French high command, 4rg.

England, war mission from, to United States, 12-13.

Erwin, General James B., 254 n.

Esperey, General Franchet d', 127.

Faison, General S. L., 324 n.

Farnsworth, General C. S., in command of Thirty-seventh Division, $25+\mathrm{n}$.

Farr, Colonel Otho W. B., $156 \mathrm{n}$.

Fatherless Children of France, work of the, 381 .

Feland, Colonel Logan H., 4I I, 412.

Field hospitals, $221,222$.

Field officers, course for, 69.

Field signal battalions, 2 I 6 .

Fifth Corps, in September, 1918, 250; in operations against St. Mihiel, 270.

Fif th Division, in September, 1918, 253 ; the first to cross river Meuse, $301 \mathrm{n}$.

Fighting units, organization of, 4752.

Finance division of quartermaster corps, 228.

First American Army Corps, creation of, 155-156; Order of Battle July 4, 1918, 155 n.; in September, 1918, 249; in operations against St. Mihiel, 269; order of battle December I, 1918, 392-397.

First Division, arrival and establishment of, in France, 116-122; inspected by Secretary of War Baker, rzo; confided to Fifth French Army, 137; splendid qualities of, $137-138$; Order of Battle of, May I, 1918, 138 n.; operations of, in spring defensive of 1918, 1 $39 \mathrm{ff}$.; successful storming of Cantigny by, 143-44; losses of, 145 ; situation of, on eve of summer counter-offensive, 168 ; operations of, $175-177$; in September, $1918,253$.

Fiske, Harold B., $46 \mathrm{n}$.

Flagler, General C. A. F., 253 n.

Floyd, Mrs., 380 n.

Foch, General, made supreme commander of Allied forces on Western front, I34; congratu- lates American soldiers after storming of Cantigny, 145 .

Foltz, General F. S., $256 \mathrm{n}$.

Ford, Colonel Stanley H., 324 n.

Ford, General, member of Military

Board of Allied Supply, $358 \mathrm{n}$.

Forman, Lt.-Col. Albert W., $250 \mathrm{n}$.

Forty-second Division, entrance of, into active service, $128-129$; inspected by Secretary of War Baker, 130; Order of Battle on July ro, 19r8, 160 n.; losses of, in defending the Marne, 167 ; situation of, on eve of summer counter-offensive, I7r; in September, I918, 253.

Foulois, General, 202.

Fourth Corps, in September, 1918, 249-250; in operations against St. Mihiel, 269.

Fourth Division, situation of, on eve of summer counter-offensive, r69; consolidated with First American Corps, 178 ; in September, 1918, 253; operations of, on British front, $320 \mathrm{ff}$.

Fox-Connor, General, $46 \mathrm{n}$.

Foyer du Soldat, collaboration of Y. M. C. A. in work of, 372 .

France, war mission from, to United States, 12-13; arrival of General Pershing in, 36 ; arrival of first American contingents in, I1 6-128.

Franco-American coöperation, 385390.

Fraternization, unsuccessful German attempts at, 316-318.

French Tuberculosis War Victims, founding of, 382 .

Fries, General, chief of gas service, 239.

Galbraith, Colonel F. W., 254 n.

Garrett, W. A., American railway expert in France, 112.

Gas defense school at Chaumont, 75.

Gas mask, efficiency of the, designed by medical corps, 86 .

Gas masks, deliveries of, 24 r.

Gas Regiment, organization of, 239-240. 
Gas school, army, in France, 67.

Gas service of American army, 239. Gasser, Lt.-Col. Lorenzo D., $173 \mathrm{n}$. General Purchasing Board, account of the, 354-359.

General Staff, formation of, by General Pershing, 45; five sections into which divided, 45-46; function of adjutant-general, 4647.

Geological section of engineer service, 200-201.

Germans, bulletin of, quoted on American soldiers, 153 ; superiority of American artillery over that of, 192; position of forces of, opposed to Americans at St. Mihiel, 27I; account issued from headquarters, concerning American-French assault on St. Mihiel, 275-276; order of battle in Meuse-Argonne operations, 286287 ; occupation of territory of, after the armistice, by Allied forces, 312-319; wisdom of, in capitulating, 360 .

Germany, diplomatic error of, in regard to United States, 3 ; proclaims that United States will have peace at any price, 4 ; continued acts of provocation by, 5so; breaking off of diplomatic relations with, ıо; United States declares war upon, II.

Gettysburg and St. Mihiel contrasted, 277.

Gibson, Colonel, Red Cross commissioner for France, 368.

Gièvres, main American storage depot at, 109, 347 .

Gironde region, installations by Americans in, 342-345.

Glassford, Colonel P. D., I 55 n.

Goethals, Quartermaster-General, 333.

Gondrécourt, camp at, for training of First Division, 44, 59; installation of First Division at, 118 .

Gordon, General Walter H., in command of Sixth Division, $254 \mathrm{n}$.

Graves registration service of American army, 229; work done by, $231-232$.
Greble, Lt.-Col. E. St. John, Jr., $162 \mathrm{n}$.

Grunert, Major George, 155 n.

Guns, supply of, for A. E. F., 236237.

Gwin, Mrs. William, $380 \mathrm{n}$.

Hacker, Colonel T. B., chief of salvage service, $23 \mathrm{I}$.

Haig, Field Marshal Sir Douglas, congratulations of, expressed to Second American Army Corps, 328-329.

Hale, Colonel R. K., 324.

Halen, General John A., 257 n.

Hall, Colonel Charles L., $249 \mathrm{n}$.

Halstead, Colonel Frank, $258 \mathrm{n}$.

Hamilton, Colonel Clad., $253 \mathrm{n}$.

Han, General William G., in command of Thirty-second Division, I 70.

Hanson, General T. G., 252 n.

Harbord, General James G., first chief of staff of American army, $45 \mathrm{n}$.; in command of Fourth Infantry Brigade (Marines), 146 n.; high qualities of, 147; succeeds to command of Second Division, 168 ; in charge of service of supplies, $339 \mathrm{n}$.; cited in general orders by French high command, 4 ro.

Harjes, Mr., president of American Relief Clearing House, 382.

Harjes, Colonel Herman, $386 \mathrm{n}$.

Harris, Colonel A. J., 255 n.

Harsey, General Mark L., $255 \mathrm{n}$.

Hartman, Colonel Ed. T., $252 \mathrm{n}$.

Haskell, Lt..Col. W. H., $250 \mathrm{n}$.

Haubery, Colonel Sanford B., $254 \mathrm{n}$.

Hawkins, Colonel Clyde E., $258 \mathrm{n}$.

Hawkins, Colonel F. B., 253 n.

Hay, General William H., 254 n.

Hayward, Colonel, distinguished services of, 4 I 4 .

Headquarters and supply section of field signal battalions, 216 .

Healdton, sinking of, ro $\mathrm{n}$.

Hearn, Edward L., Supreme Knight, Knights of Columbus, 374 .

Heidt, Colonel J. M., $257 \mathrm{n}$.

Heintzelman, Colonel Stuart, $250 \mathrm{n}$. 
Herr, Lt.-Col. J. K., 324 n.

Herrick, American ambassador in Paris, 382.

Herrick, Colonel H. S., 324 n.

Hill 204, attack on, shared by 3 oth Regiment, 158.

Hines, General John L., $138 \mathrm{n}$; in command of Third Corps, 297.

Holbrook, Colonel I. R., $138 \mathrm{n}$.

Hollingsworth, Lt.-Col. C. P., $253 \mathrm{n}$.

Hoover, Colonel John S., 257 n.

Hospital system, organization of, 220-223; in the interior, 225226.

Hospital trains, 225, 379-380.

Hostess ' houses established in France by Y. W. C. A., 378 .

Hough, Colonel Benson W., I60 n. Housatonic, sinking of, ro.

House, Colonel, seconds idea of unified high command among Allies, 133 .

Hume, Colonel Frank M., r 54 n.

Hunt, Colonel Charles A., 413.

Hunt, Colonel Henry J., 253 n.

Illinois, sinking of, ro n.

Infantry schools in France, 66.

Information, section of, American army, I9r.

Inspection service of quartermaster corps, 228.

Inspector-general's department of American army, 242-244.

Instruction of American forces in France, principles governing, 5559.

Intelligence school, army, in France, 69.

Inter-Allied Tank Committee, 196.

Irwin, Colonel Isaac, I7I $\mathrm{n}$.

Irwin, General Le Roy G., r7o n.

Is-sur-Tille, American regulating station at, IIr.

Italy, Expeditionary Forces detached for operations in, 329330.

Jackson, Colonel W. E., 257 n.

Jackson, General W. P., 254 n.

Jadwin, General E., engineer corps under direction of, 198 .
Jamerson, General George H., $256 \mathrm{n}$.

Jennings, Colonel E. S., $324 \mathrm{n}$.

Jewish Welfare Board, affiliated with Y. M. C. A., 363, 372; account of work of, $377-378$.

Joffre, member of French war mission to United States, 12; Pershing met by, in Paris, 36; advises early appearance of American contingent on French soil, Ir6; visit paid by, to first American troops, I19.

Johnson, General E. M., I $7 \mathbf{I}$ n.

Johnson, Lt.-Col. Gordon, $25 \mathrm{I}$ n.

Johnson, Colonel W. O.. $257 \mathrm{n}$.

Johnston, General William H., in command of Ninety-first Division, $256 \mathrm{n}$.

Jones, Colonel Harry C., 255.

Judge-advocate of American army, 244-245.

Juvigny, capture of, 183-184.

Kemp, Colonel George M., 162 n.

Kenly, General, 202.

Kernan, General, in charge of service of supplies, $339 \mathrm{n}$.

King, General Edw. L., 255 n.

Klemm, Colonel Karl D., 253 n.

Knights of Columbus, 318 ; under direct control of high military command, $36_{3}$; founding of, and early work, 372 ; work done by, in European conflict, 373-374.

Knowles, Colonel Alden C., $257 \mathrm{n}$.

Kuhn, General Joseph E., in command of Seventy-Ninth Division, $257 \mathrm{n}$.

Laconia, sinking of, ro $\mathrm{n}$.

La Courtine, American artillery training camp at, 62 .

Lafayette, American soldiers at tomb of, 118 .

Lafayette squadron, the, 207-208.

Langdon, Colonel C. R., r7o n.

Langres, army general staff college at, $65-66$.

$\mathrm{La}$ Pallice, as a base port for American use, 95.

Lassiter, General, in command of Fourth Corps artillery, 269.

Lathrop, Mrs., $380 \mathrm{n}$. 
Leach, Colonel George E., I 60 n.

Le Mans, chaplains' school at, 76 .

Lenihan, General M. J., 160 n.

Lewis, Colonel E. A., $257 \mathrm{n}$.

Lewis, General E. M., 146 n., $324 \mathrm{n}$.; forces of, take Vaux Village, I 53-1 54 .

Liberty engine, adoption of, by aviation service, 84 .

Liberty No. 8 tank, 194-r 95 .

Libourne, training center for heavy artillery at, 63 .

Libraries established in France, 375-377.

Library Association. See American Library Association.

Liffol-le-Grand, American regulating station at, I I I-1 12 .

Liggett, General Hunter, in command of First Army Corps, 155$156,249,269$; placed in command of First Army, 296.

Limoges, training center for heavy artillery at, 63 .

Lincoln, President, position of, prior to Civil War, 2, 3 .

Lindsey, General J. R., $252 \mathrm{n}$.

Lines of communication, activities in connection with establishment of, 78-115; work of signal corps to establish, 2 I4 .

Little, Major, 414.

Lloyd, Colonel Charles Rees, $156 \mathrm{n}$.

Locke, Colonel Morris E., I $55 \mathrm{n}$.

Locomotives, shipment of, to France, 337 ; overhauling of French, by Americans, 352.

Logan, Colonel E. L., I $54 \mathrm{n}$.

Logan, General James A., $45 \mathrm{n}$.

Logan, Major, head of American military mission in France, 9294.

Loire, changes wrought in region of the lower, by American S. O. S., 342 .

Lost Battalion, Major Whittlesey and the, 295 .

Lusitania, sinking of, 6 .

Lyman M. Law, sinking of, Io.

Lynch, Colonel J. A., 254 n.

McAlexander, Colonel Ulysses G.,
$156 \mathrm{n} ., 414$; praise of, by a French officer, 166.

McAlexander, General V. S., 252.

McAndrew, General James W., appointed chief of staff of American army, $45 \mathrm{n}$. ; head of army general staff college at Langres, 65-66.

McArthur, Colonel John C., 252 n.

McCleave, Colonel R., 249 n.

McCloskey, Colonel Manus, $147 \mathrm{n}$.. I $7 \mathrm{I}$.

McClure, General N. F., $253 \mathrm{n}$.

McCormick, Colonel C. B., $170 \mathrm{n}$.

McCoy, Colonel Frank, r6o n.

McCoy, Colonel Robert, izo n.

McCrae, General James H., in command of Seventy-eighth $\mathrm{Di}$ vision, $255 \mathrm{n}$.

McDonald, General J. B., $256 \mathrm{n}$.

McFarland, General M., $258 \mathrm{n}$.

McGlachlin, General, in command of artillery of First Army, 191.

Machine-gun battalions, citation of, in general orders of French high command, 417-418.

Machine-gun company, composition of a, 50 .

Machine-gun school in France, 66.

McIver, General G. W., $258 \mathrm{n}$.

Mackall, Lt.-Col. S. T., $250 \mathrm{n}$.

McKinley, President, position of, at time of war with Spain, $2 \mathrm{n}$.

McKinstry, General C., r6o n.; light railway service directed by, 199.

McMahon, General John, in command of Fifth Division, $253 \mathrm{n}$.

MacMaster, Colonel H., $253 \mathrm{n}$.

Maine, blowing up of the, $2 \mathrm{n}$.

Malone, Colonel Paul B., $46 \mathrm{n}$, I 47 n., 253, 4I3.

Marines, the, 147 ; distinguished behavior of, at Belleau Wood, 152-153; cited in general orders by the French high command, $410-411$.

Maritime bases constructed by Americans in France, 342-343.

Marne, part taken in defense of, by American troops (1918), r59167.

Marseilles, American base section at, 346 . 
Martin, General Charles i., $253 \mathrm{n}$.

Meat, American, for army in France, $343-344,347-348$.

Medical corps, activities of the, 85-86, I87; hospitals established by, 108 .

Medical service, organization and achievements of American, in France, 219-225; in the interior, 225-226.

Medical supplies, statistics of, 226.

Menoher, General Charles T., in command of Forty-second Division, I28, 160, 164.

Merritt, Camp, 86.

Merrone, General, Italian member of Military Board of Allied Supply, $35^{8} \mathrm{n}$.

Metts, Colonel J. Van B., $324 \mathrm{n}$.

Meucon, American artillery training camp at, 6I, 62; American balloon school at, 72; artillery aërial observation school at, 73 .

Meuse, operations between Argonne Forest and, 277-306.

Mézey, fight between Second Division and Germans near, r22-124.

Miles, Colonel, 4I5.

Military Board of Allied Supply, 245; account of, 354-358; results secured by, summarized, 358-359.

Military schools in France, plan for organization of, $63-77$.

Mills, Camp, 86.

Miner, Colonel Asher, $162 \mathrm{n}$.

Minor, Colonel S. W., $324 \mathrm{n}$.

Mitchell, Colonel Americus, 202, 252 n., 4 I 6.

Mobile hospitals, 22 I, 222.

Mobilization of American forces for war, 13-32.

Montoir, storage depot at, 99 ; improvements at, 342 .

Morgan, Miss Anne, 381 .

Morgan, Colonel John M., $255 \mathrm{n}$.

Morrow, Colonel Wm. V., I7o n.

Morton, General Charles G., in command of Twenty-ninth Division, $255 \mathrm{n}$.

Moseley, General George Van H., $46 \mathrm{n}$.

Moses, Colonel G. W., $258 \mathrm{n}$.

Moss, Colonel James A., $254 \mathrm{n}$.
Motor transport corps, II4-115, 245-246, 352-354.

Motor transport school, 75 .

Mott, Colonel T. Bentley, $386 \mathrm{n}$.

Muir, General Charles H., in command of Twenty-eighth Division, I62; known by his men as "Uncle Charlie," r 70.

Munson, Colonel Fred L., $257 \mathrm{n}$.

Music, school for instruction in military, 75 .

Murphy, Colonel Pierce A., $253 \mathrm{n}$.

Myer, Colonel E. A., 255 n.

National Guard, condition of, at outbreak of war with Germany, 13-14.

Navy, work of, in protecting troops en route to France, 91-92.

Nelson, Colonel H. B., 252 n.

Neuilly ambulance, the, 379 .

Neville, Colonel W. C., r47 n.

Nevin, Mrs. Ethelbert, $380 \mathrm{n}$.

Newell, Colonel Isaac, $254 \mathrm{n}$.

Nicholson, General W'm. J., 257 n.

Ninetieth Division, order of battle in September, 1918, $252 \mathrm{n}$.

Ninety-first Division, in September, 1918, 256.

Ninety-second Division, in September, 1918, 254.

Nivelle, General, 133.

Noble, General K. H., 257 n.

Nolan, General Dennis E., 46 n.

Norton-Harjes ambulance service, 380 .

Nuttman, Colonel L. M., 252 n.

Officers' training camps, organization of, 23 ; course of instruction at, 24; work of, as summarized by Secretary of War, 25-26; opened in training areas of divisions of National Guard or National Army, 27-28; for colored officers, 28.

Oil, statistics of, supplied to American army, 230.

O'Neil, General J. P., 252 n.

Ordnance department of American army, 232-238; function of, in peace time, 8o; difficulties encountered by, in meeting war- 
time demands, $82-84$; recruiting of personnel, 238-239.

Ordnance equipment of American army in France, 53-55.

Ordnance schools, $7+-75$.

Organization of main services of American Expeditionary Forces, I $86 \mathrm{ff}$.

Ornans, American artillery training camp in zone of, 62 .

O'Ryan, General J. F., 324 n.

Oury, Colonel Wm. H., 257 n.

Outpost company of signal corps, 217.

Painlevé, French Minister of War, 36,39, I I 9,385 .

Palmer, Colonel John McA., $46 \mathrm{n}$.

Paris, first American battalion to parade in, 117-1 18.

Parker, Colonel Cortland, ${ }_{3} 8 \mathrm{n}$.

Parker, Colonel Frank, r $38 \mathrm{n}$., 386 n., 413.

Parker, Colonel J. H., r 54 n.

Parrott, Colonel Ralph B., 254 n.

Parsons, William Barclay, railway expert in France, 112.

Patrick, General, chief of air service, 203.

Payne, Colonel Brooke, $253 \mathrm{n}$.

Payot, General, director of French service of the rear, II2; president of Military Board of Allied Supply, $358 \mathrm{n}$.

Pearce, Colonel E. d'A., 252 n.

Pearce, Colonel Thomas A., $258 \mathrm{n}$.

Penhouet, shipbuilding yards at, 99 .

Penner, Colonel Carl, i7i n.

Perkins, James H., work of, in connection with Red Cross, 368.

Perry, Colonel Howard R., $256 \mathrm{n}$.

Pershing, General John J., departure of, for France, 33; career of, prior to appointment as commander of American Expeditionary Forces, 33-36; officers who accompanied, 36 ; visit of, to London and arrival in Paris, 36; plans of, for organization of his army, 36-37; two dominant ideas of, 37; close acquaintance of, with characteristics of his men, $37-38$; choice of debarkation ports and of railroads by, 38-
39; interviews between General Pétain and, 39-44; decisions arrived at, with Pétain, 43-44; organization of General Staff by, 45-46; constitution of fighting units by, 47-52; establishes headquarters at Chaumont, 77 ; organization of services of the rear, 92-116; at tomb of Lafayette, 118; advice of, on practical methods of fighting, r19; work of American soldiers closely followed by, 125-126; eagerness of, to learn from French experience, 127; in favor of a unified high command among Allies, 133; places American forces at disposal of General Foch, 134; previous safeguarding by, of autonomy of Expeditionary Forces, 134-135; recommends employment of American troops in large units, 135; attitude of, toward summer counter-offensive of 1918, 167-168; desire of, that American divisions be maintained side by side in summer counter-offensive, 173; firm policy of, in handling his forces, 184-185; correct military intuition of, 185 ; plan of, in having all heads of main services stationed for a time at Chaumont headquarters, 186 ; importance of air service recognized by, 202 ; position of forces of, at beginning of September, 1918, 247261 ; account of operations of, against St. Mihiel, 262-276; entrance of, into St. Mihiel, 276277; street in St. Mihiel named for, 277 n.; activities of, in operations between river Meuse and Argonne Forest, 278-306; General Order issued by, upon signing of armistice, 307-308; creation of General Purchasing Board by, 355-356; creates InterAllied Board for Purchasing, 356; service rendered by, in securing unity of purchase, 357 ; treatment of the great benevolent associations by, $362-363$; report by, on value to American army 
of French coöperation and assistance, $387-388$.

Persia, sinking of, 8.

Personal division of quartermaster corps, 228.

Pétain, General, 39, I3I, I36. $137 \mathrm{n}$.; position of, in a military way, 39-4I; General Pershings' first visit to, $4 \mathrm{I}$; collaboration of Pershing and, 42-45; inspects front line of battle on the Marne (1918), 162; advice by, on "No maneuvring under fire," 163 ; cooperation between Pershing and, in autumn offensive of 1918, 264; entrance of, with General Pershing, into St. Mihiel, 276-277.

Peyton, Lt.-Col. Ephraim G., $256 \mathrm{n}$.

Photographic division of signal corps, 2 I9.

Pickering, Lt.-Col. 254 n.; distinguished services of, 4I4.

Pierce, General P. E., 324 n.

Pigeon school at Saizerais, 75 .

Plattsburg, officers' training camp at, 23.

Plunkett, Rear-Admiral, in command of naval gunners, 192 .

Poincaré, President, review of first American troops by, I19.

Police duties, schools for, 75 .

Pope, Lt.-Col. William R., $255 \mathrm{n}$.

Ports, choice of, for use of Americans in France, 94-96.

Prentice, Captain John H., 25 I n.

Price, Colonel H. C., $252 \mathrm{n}$.

Price, Colonel H. J., $258 \mathrm{n}$.

Price, General William G., 162 n.

Priority schedule, the, 9r.

Purchasing board and agent, establishment of, in Paris, 105.

Quartermaster corps, functions of, in peace time, 80 ; reorganization of, to meet war-time emergencies, 81-82; duties devolving on, 227-229; results accomplished by, 230-232; personnel of, 232 .

Radio company of signal corps, 217. Railway lines, choice of, for linking American base ports with combat zone, 97, I04.

Railway service, organization of
American, in France, 112, 199, 350-351.

Railway transportation school, 76 .

Read, General G. W., in command of Second Army Corps, 249, 322, $324 \mathrm{n}$.

Reckord, Colonel Milton A., $255 \mathrm{n}$.

Recruiting system, mechanism of, for carrying out universal military service measure, 17-20.

Red Cross, American, 318; entrusted with care of sick and wounded, 363 ; under direct military control, 363 ; account of work of, $364-368$.

Reeves, Colonel James H., 252 n.

Regiment, composition of a, 50; command of a, $5 \mathbf{r}$.

Regulating stations, system of, r roI I 2.

Reilly, Colonel Henry J., I60 n.

Relief Clearing House, American, 382.

Remount division of quartermaster corps, 229; achievements of, $230-231$.

Renault type of tank, 194, 195.

Repair shop organization, 235-236.

Replacement divisions, 48.

Requirements division of ordnance department, 233 .

Rhine, march of Franco-American army to the, 307-319.

Rhodes, General C. D., 252 n.

Ribot, French Prime Minister, 12.

Richards, Colonel George C., I62 n.

Richardson, Colonel L. T., $25^{8} \mathrm{n}$.

Rifle shortage at beginning of war, $3 \mathrm{I}$.

Riggs, Lt.-Col. K. T., 324 n.

Rivers, Colonel W. C., $156 \mathrm{n}$.

Road-service section of engineer service, 199.

Rockenbach, General, chief of tank corps, 194.

Rogers, Quartermaster - General Harry L., 227.

Roosevelt, Theodore, correspondence between Secretary of War and, 6: military preparedness advocated bv, $14 \mathrm{n}$.

Rumbold, Colonel F. M., $253 \mathrm{n}$.

Russell, General, chief signal officer, 218. 
Russell, Lt.-Col. George M., 250 n. Russia, Expeditionary Forces detached for operations in, 330 .

Saint-Mihiel, discussion of operations for taking, by Pershing and Pétain, 43; early plans bearing upon, 262-264; maturing of plans for operations against, in September offensive, 264-271; the American assault on, 272-276; entrance of Pershing and Pétain into, 276-277.

St. Nazaire, as a base port for American use, 39, 94-95; work of improving conditions at, 99roo; description of, 342 .

St. Pierre des Corps, American salvage service headquarters at, 348-349.

St. Sulpice-Izon, American storage depot at, 102, 344-345.

Salvage service of American army in France, 228-229; results of work of, $23 \mathbf{1}$; description of work, 348-349.

Salvation Army, 318; under direct control of high military command, 363 ; account of work of, 374.

Sanborn, Colonel Joseph B., $255 \mathrm{n}$.

Sanitary school, army, in France, 67.

Sanitary sections, mentioned in general orders of French high command, 419-420.

Saumur, army school at, 68 ; artillery school at, 70 .

Schools in France: army, 65-70; corps, 70-72; for aviation, 7274 ; for ordnance, 74-75; for miscellaneous branches of service, 75-76; the inter-allied, 76 .

Scientific section of American Red Cross, 367.

Screws, Colonel Wm. P., r6o n.

Searchlight section of engineer service, 200; mentioned in general orders of French high command, 4 I9.

Second Army Corps, 249 ; Order of Battle of, $324 \mathrm{n}$.; distinguished services of, $326-327$; order of battle, December 1, 1918, 398401 .

Second Division, training of, received in France, 122; gives good account of itself, 122-124; inspected by Secretary of War Baker, 130; passes into ranks of French Fifth Army, 146; Order of Battle of, June 1, 1918, 146 n.; operations of, in spring defensive of $1918,147 \mathrm{ff}$.; attack and capture of Belleau Wond by, 151-153; a German army bulletin quoted concerning, 153; capture of Vaux Village by Third Brigade, 1 53-154; losses of, 155 ; situation of, on eve of summer counter-offensive, 168 ; operations of, 175-177; in September, 1918, 253.

Seicheprey, gallant conduct of Twenty-sixth Division at, r3II32.

Sergy, fighting about village of, 179-180.

Services of Supply (S. O. S.), composition of, 187 ; organization of, 339; functions of three sections of, 339-340; base, intermediate, and advance section of, $341-349$.

Services of the rear, organization and work of, 78-82, 88-89, 92115; General Order which created, ro3-ro4; reorganization of, in spring of $1918,187-188$; account of activities of, 33r-359; projects under way, when armistice was signed, 359-360.

Seventh Corps, in September, 1918, 250.

Seventh Division, 257.

Seventy-eighth Division, in September, 1918, 255; operations of, on British front, $320 \mathrm{ff}$.

Seventy-ninth Division, in September, $1918,257$.

Seventy-seventh Division, situation of, on eve of summer counteroffensive, 17r; Order of Battle on August 19, 1918, 171 n.; operations of, on British front, $320 \mathrm{ff}$. Shannon, Colonel Ed. C., $162 \mathrm{n}$.

Shaw, Mrs. Francis, $380 \mathrm{n}$.

Shelton, Colonel George H., r54 n. 
Sherburne, Colonel J. H., I55 n.

Sherill, Colonel, 4r7.

Shipment of troops to France, problems and achievements connected with, 87-88, 334-336.

Shortage of military equipment at opening of war, 31 .

Sibert, General, in command of First Division, I I 7-122.

Signal corps, functions of, in peace time, 80; work of, in France, 108, 213-216; personnel of, 2 18.

Signal school, army, in France, 67.

Simonds, Colonel G., $324 \mathrm{n}$.

Sims, Admiral, in London to organize protection of American ships, 91 .

Sixth Corps, in September, 1918, 250.

Sixth Division, 254.

Sixty-fourth Infantry Brigade ("The Terrible Brigade"), 4II.

sladen, General Fred W., $156 \mathrm{n}$.

Smedberg, Colonel W. R., Jr., I $71 \mathrm{n}$.

Smith, Colonel Ernest V., $254 \mathrm{n}$.

Smith, Lt.-Col. F. H., I 7 r n.

smith, Colonel Hamilton, r38 n.

Smith, General William R., in command of Thirty-sixth Division, $257 \mathrm{n}$.

Souge, American artillery training camp at, 6r, 62; artillery aërial observation school at, 73 .

Spanish-American War, slowness of United States in beginning, 2.

Spence, Colonel C. F., $324 \mathrm{n}$.

Spencer, Major, 4I4.

Spring defensive of 1918, 133-167.

Staff of a division, composition of, $5 \mathrm{I}-52$.

Stark, Colonel, army surgeon of First Army, 223.

Stettinius, Edward R., Second Assistant Secretary of War, 333.

Stewart, General M. B., 258 n.

Stillwell, Major Joseph, $250 \mathrm{n}$.

Stokes, Colonel Marcus B., $255 \mathrm{n}$.

Storage depots established by Americans in France, 343-345.

Stretzinger, Colonel F. G., 254 n.

Students' Army Training Corps, $22 \mathrm{n}$.

Sturdevant, Colonel G., $258 \mathrm{n}$.
Submarines, German, outrages by, 6-8.

Summerall, General C. P., $3_{38}$ n., 139, 140; succeeds General Bullard in command of First Division, 168 ; in command of Fifth Corps, 297.

Summer counter-offensive of $19 \times 8$, I 67-184.

Supplies division, of quartermaster corps, 228; of ordnance department, 234 .

Sussex, sinking of, 8.

Sweezy, Colonel Claude B, $257 \mathrm{n}$.

Taft, former President, work of, in connection with Red Cross, 368.

Tank school of American army in France, 70 .

Tanks, different types of, 193-195; good use made of, by American troops, I97; used by American army in Argonne Forest, 289.

Tardieu, André, director of General Commission for FrancoAmerican War Affairs, $387 \mathrm{n}$.

Taylor, Colonel James D., $252 \mathrm{n}$.

Taylor, Colonel W. A., 324 n.

Taylor, General, at head of engineer service, $197 \mathrm{n}$.

'Telegraph and telephone equipment, 218.

Telegraph battalions, 216.

Telephone system, excellence of American, in France, 219.

Third American Corps, staff of, on July 16 , 1918, 173 n.; operations of, on Vesle River, $181-183$; in September, 1918, 249; occupation of Coblenz bridgehead by, 315; Order of Battle December I, 19I8, 40I-406.

Third Division, operations of, in spring defensive of 1918, 156158; Order of Battle of, May 31, 1918, 156 n.; situation of, on eve of summer counter-offensive, 168-169; in September, 1918, 253.

Third Infantry Brigade, cited in general orders by French high command, 4 ro.

Thirtieth Division, operations of, on British front, $320 \mathrm{ff}$.

Thirtieth Regiment of Infantry, 
cited in general orders by French high command, +13-4I 4 .

Thirty-fifth Division, in September, 1918, 253; operations of, on British front, $320 \mathrm{ff}$.

Thirty-second Division, composition of, 170; operations of, 183 .

Thirty-seventh Division, in September, 1918, 254.

Thirty-sixth Division, in September, 1918, 257.

Thirty-third Division, in September, 1918, 255; operations of, on British front, 320 ff.; distinguished services of, 323 .

Tours, headquarters of Services of Supply at, 187 ; air training sections at, 202, 203; aviators graduated from school at, 207; activities of American medical corps at, $220 \mathrm{ff}$.; headquarters of American forces at, 339 .

Tractor artillery school in France, 70.

Training camps, for officers, 23 ; for troops, 29-30; for American forces in France, 46; principles governing instruction in France, 55-59.

Transportation, department of, 245-246.

Transportation of American soldiers to France, $78-79,87-88$, 333-338.

Transportation lines, work of experts on, II2-II4.

Traub, General Peter E., I54 n.; in command of Thirty-fifth Division, $253 \mathrm{n}$.

Tupes, Colonel, 4r 5 .

Twenty-eighth Division, Order of Battle on August 1, 1918, 162 n.; situation of, on eve of summer counter-offensive, I69-170; opertions of, on British front, $320 \mathrm{ff}$.

Twenty-ninth Division, in September, 1918, 254, 255.

Twenty-sixth Division, arrival and early activities of, in France, 124-125; fight of, at Seicheprey, 131-r32; Order of Battle of, July ro, 1918, 154 n.; situation of, on eve of summer counter-offensive, 169; in September, 1918, 253.
Twenty-seventh Division, operations of, on British front, $320 \mathrm{ff}$.

Tyndall, Colonel R. H., i6o n.

Tyson, General L. D., 324 n.

Tyson, Mrs. Russell, $380 \mathrm{n}$.

$U 2 I$, German submarine, 6 .

Ulio, Major James, $250 \mathrm{n}$.

United States. See America.

Unity of purchase, the securing of, 355-357.

Universal military service measure, passage of, r2-r3.

Upton, Colonel Leroy, $146 \mathrm{n}$; of 9 th Regiment of Infantry, 412.

Vail, Miss Anna M., $380 \mathrm{n}$.

Valbonne, American army school at, 68.

Valdahon, American artillery training camp at, 60 .

Vandenburg, General, I4r n.

Vaux Village, capture of, by Third Brigade of Second Division, I 53-r 54.

Vesle, crossing of the, 180.

Vidner, Colonel G., I 7 I n.

Vigilancia, sinking of the, ro n.

Villers-Bretonneux, raid near, 323.

Vincent, General, in command of First Corps artillery, 269.

Viviani, head of French war mission to United States, $12 \mathrm{n}$.

Wadhams, Colonel, 220; coördination of medical activities at the front by, 221-223.

Wahl, General Lutz, 257 n.

Walch, General, in charge of artillery of First Corps, $282 \mathrm{n}$.

Wales, Colonel Boyd, i 7 I n.

Walker, Colonel Kirby, $253 \mathrm{n}$.

Walker, General M. L., head of

- Motor Transport Corps, 352.

War Council at Versailles, I33I34.

War Industries Board, formation of, 332 .

Water supply service, functions of, 200.

Watkins, Colonel Lewis H., 249 n.

Weeks, Colonel George MacD., $257 \mathrm{n}$.

Weigel, General William, I62 n.; 
in command of Eighty-eighth Division, $258 \mathrm{n}$.

Welfare and recreation bureaus of American Red Cross, 367.

Wells, General Briant H., $250 \mathrm{n}$.

Westnedge, Colonel Jos. B., I70 n.

Wharton, Mrs. Edith, work of, $38 \mathrm{I}$.

White, Colonel George P., 253 n.

Whitman, Colonel Walter M., $252 \mathrm{n}$.

Whittlesey, Major, commander of famous "Lost Battalion," 295.

Wilcox, Colonel C. de Witt, $386 \mathrm{n}$.

Wilgus, W. F., member of commission of specialists in France, 99; plans designed by, for railroad system at Bassens, ror; appointed deputy director-general of transportation in France, I05; member of commission of railway experts, I 12.

Williams, Colonel H. C., $252 \mathrm{n}$.

Williams, Lt.-Col. R. H., I 55 n.

Williams, General, chief of ordnance department, 233.

Wilson, Lt.-Col. James E., $253 \mathrm{n}$.

Wilson, President, breaks off diplomatic relations with Germany, ro; declares state of war between Germany and United States, II; satisfaction of, over unification of Allied command, r $34 \mathrm{n}$.

Winans, General Ed. B., r70 n.
Winn, General Frank L., in command of Eighty-ninth Division, $252 \mathrm{n}$.

Wire company of signal corps, 217.

Wise, Colonel Hugh D., $253 \mathrm{n}$.

Wittenmyer, General E., r7I n.

Witworth, General Pegram, 257 n.

Woevre, repulse of German force at, I3I.

Wolf, General Paul A., 255 n.

Wolfe, Colonel O. R., 324 n.

Wood, General Leonard, crusade of, for military preparedness, $\% \mathrm{n}$.; influential in organizing officers' training camps, 23.

Woolnough, Lt.-Col. J. B., 257 n.

Worillow, Colonel Ulysses G., $256 \mathrm{n}$.

Wright, Colonel William K., $257 \mathrm{n}$.

Wright, General W. W., in command of Seventh Corps, 250, $25 \mathrm{In}$.

Young Men's Christian Association, 318; duties assigned to, by General Pershing, 363; under direct military control, 363 ; account of work of, 368-372.

Young Women's Christian Association, 363 ; affiliated with Y. M. C. A., 372; work done by, 378379.

Zimmerman, General C. X., 254 n. 


UMASS / BOSTON LIBRARIES

1001038734

D500.C43 A6 $1 \mathrm{GC}$

The American army in the 
